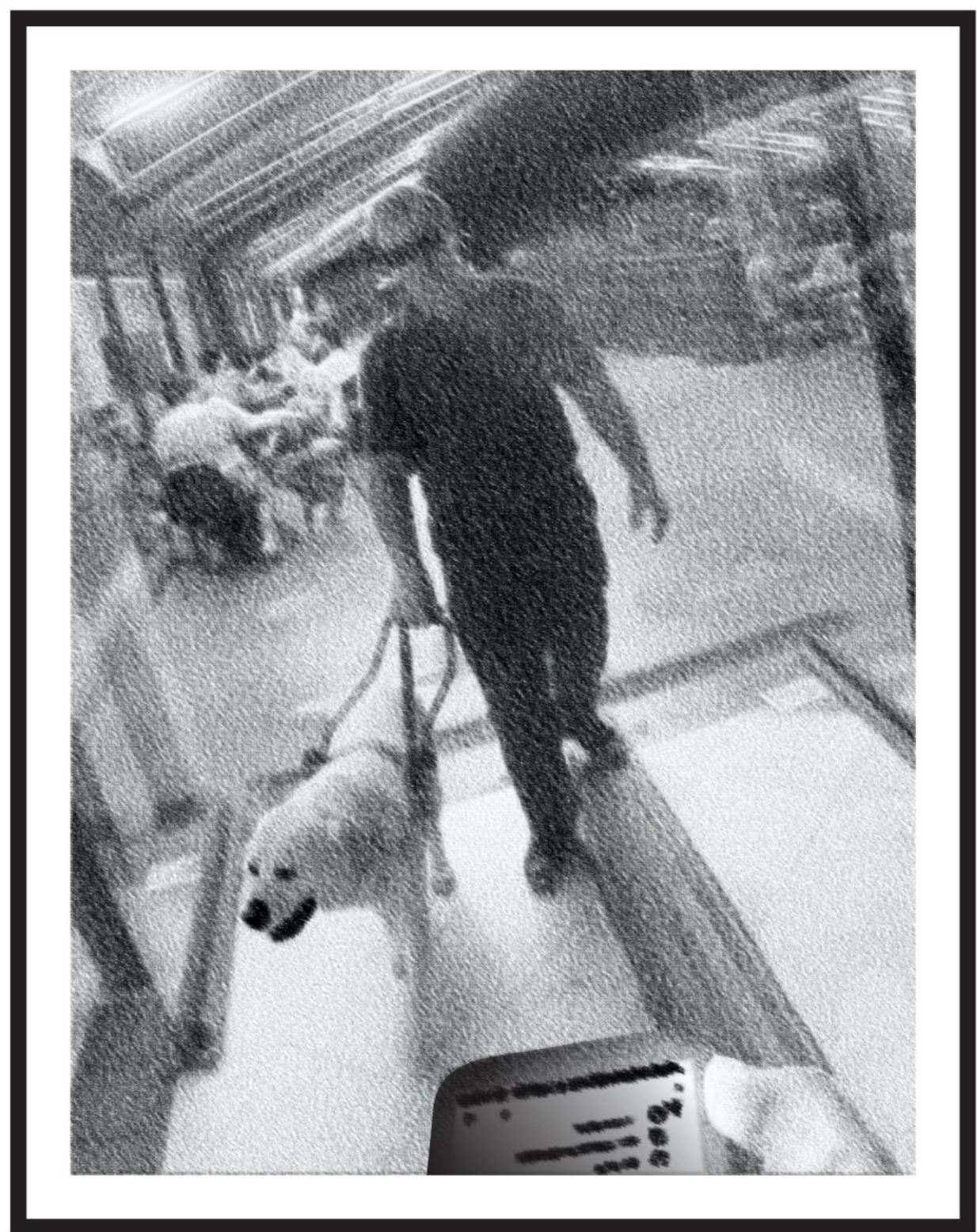

\title{
Princípios para o design de audionavegação em ambientes públicos para pessoas com deficiência visual
}

\author{
JALDOMIR DA SILVA FILHO
}

São Paulo 

Princípios para o design de audionavegação em ambientes públicos para pessoas com deficiência visual

Dissertação apresentada à Faculdade de Arquitetura e Urbanismo da Universidade de São Paulo para obtenção do título de Mestre em Arquitetura e Urbanismo

Área de concentração: Design e Arquitetura

Orientadora: Profa. Dra. Denise Dantas

São Paulo 
Autorizo a reprodução e divulgação total ou parcial deste trabalho, por qualquer meio convencional ou eletrônico, para fins de estudo e pesquisa, desde que citada a fonte.

E-mail do autor: jaldomir@usp.br

Catalogação na Publicação

Serviço Técnico de Biblioteca

Faculdade de Arquitetura e Urbanismo da Universidade de São Paulo

S586p

Silva Filho, Jaldomir da

Princípios para o design de audionavegação em ambientes públicos para pessoas com deficiência visual / Jaldomir da Silva Filho ; orientadora

Denise Dantas. - São Paulo, 2017.

227 .

Dissertação (Mestrado) - Faculdade de Arquitetura e Urbanismo da Universidade de São Paulo. Área de concentração: Design e Arquitetura

1. Mobilidade Urbana. 2. Orientação Espacial. 3. Deficiente Visual. 4. Voz Sintetizada. 5. Interface Homem-computador. 6. Audionavegação. I. Dantas, Denise, orient. II. Título. 
Dedico este trabalho, in memoriam, ao meu pai, Jaldomir da Silva, e ao meu irmão, Plínio Cesar Araújo da Silva. 



\section{AGRADECIMENTOS}

Este trabalho contou com o apoio e a colaboração direta ou indireta de muitas pessoas, tantos amigos que se torna impossível citar a todos, pois seria uma lista infindável aos quais devo muito apreço e gratidão. Então citarei os que contribuíram de forma direta com o trabalho, mas sem diminuir a importância de todos.

À Faculdade de Arquitetura e Urbanismo da Universidade de São Paulo, pela oportunidade de desenvolvimento e concretização deste trabalho.

À Profa. Dra. Denise Dantas pelo apoio e o tempo dedicados à minha orientação.

Ao Prof. Dr. Luís Cláudio Portugal do Nascimento, pela valorosa amizade e pela atenção que possibilitaram a realização deste trabalho.

Ao Prof. Dr. Fausto Leopoldo Mascia, pelo incentivo e pela relevante contribuição a esta pesquisa.

À Companhia do Metropolitano de São Paulo - CMSP, pela disponibilização dos recursos necessários à realização deste trabalho.

À Arq. Eliete Mariani, pelos conhecimentos que estimularam o início, a continuidade e a conclusão deste trabalho.

Ao Vagner José de Almeida, pela dedicação e maestria na ilustração da capa deste trabalho.

À Selma Silvestre e ao João Álvaro de Moraes Felippe, especialistas em Orientação e Mobilidade, pelo auxílio com seus valorosos conhecimentos.

Aos amigos Célia, Daniela, Éber, Gabriel, Iara, Marcelo, Markiano, Milene, Regina, Renato e Sérgio, que abrilhantaram este trabalho com sua experiência e conhecimento.

À minha esposa Nanci, meus filhos Caroline e Raphael, à minha mãe, Enedina, e meus irmãos, Júlio e Felipe, pelo apoio, paciência e compreensão.

Aos citados e a todos os demais amigos que contribuíram de uma forma ou de outra, meus sinceros agradecimentos e congratulações, pois este trabalho pertence a todos nós. 



\section{RESUMO}

SILVA FILHO, J. Princípios para o design de audionavegação em ambientes públicos para pessoas com deficiência visual. 2017. 227 p. Dissertação (Mestrado em Arquitetura e Urbanismo). Faculdade de Arquitetura e Urbanismo FAU. Universidade de São Paulo - USP. São Paulo. 2017.

As pessoas com deficiência compreendem uma parcela da população as quais as formas de planejamento dos espaços urbanos causam impacto direto em sua qualidade de vida, sendo a incapacidade visual a mais abrangente entre as deficiências, acometendo mais de 35 milhões de pessoas no Brasil. Nas últimas décadas, as normas e leis brasileiras de promoção da acessibilidade buscam criar condições para que as pessoas com deficiências possam ter uma vida social e econômica mais ativa, por meio do uso dos preceitos do design universal nos projetos de acessibilidade para espaços públicos e meios de transporte. No entanto, definir regulamentos e normas tem se mostrado insuficiente, pois a simples padronização de recursos físicos, como pisos táteis, não garantem a autonomia para o deslocamento das pessoas com deficiência visual. Paralelo às adequações dos espaços públicos para a acessibilidade, algumas tecnologias eletrônicas têm sido desenvolvidas de forma efetiva para o design universal, dentre elas as atuais formas de audiodescrição de programas de TV, cinemas e teatros, assim como o desenvolvimento de tecnologias de voz sintetizada para que pessoas com deficiência visual possam fazer uso dos portáteis smartphones. Neste estudo, foram realizadas pesquisas bibliográficas e experimentos em ambientes controlados e ambientes públicos, utilizando-se de técnicas de pesquisa qualitativa para o levantamento, registro e análise de informações, por meio da observação de voluntários com deficiência visual, enquanto utilizavam um modelo primordial de equipamento com voz digital para orientá-los em três ambientes públicos na cidade de São Paulo, compreendendo uma movimentada estação de metrô, uma calçada a céu aberto e uma instituição pública de cultura. Os experimentos demonstraram que os voluntários com deficiência visual podem utilizar um formato adequado de audiodescrição para a orientação e mobilidade, contanto que sejam consideradas peculiaridades que relacionem a velocidade de marcha de pessoas com deficiência visual com os processos cognitivos pertinentes à audição e à percepção ambiental. Por consequência, esta pesquisa oferece princípios para o design de audionavegação, por meio de readequações na audiodescrição para abranger os conceitos de orientação e mobilidade, de modo a possibilitar sua aplicação em projetos de interfaces eletrônicas portáteis com voz sintetizada para orientar pessoas com deficiência visual, buscando assim um incrementando na autonomia dessas pessoas para seu wayfinding em ambientes públicos e transportes de massa.

Palavras-chave: Mobilidade Urbana. Orientação Espacial. Deficiente Visual. Voz Sintetizada. Interface Homem-computador. Audionavegação. 



\begin{abstract}
Silva Filho, J. Principles for audionavigation design in public environments for people with visual impairment. 2017. 227 p. Dissertação (Mestrado em Arquitetura e Urbanismo). Faculdade de Arquitetura e Urbanismo - FAU. Universidade de São Paulo - USP. São Paulo. 2017.

The people with disabilities comprise a portion of the population whose forms of planning in urban spaces have a direct impact on their quality of life, with visual impairment being the most comprehensive among disabilities, affecting more than 35 million individuals in Brazil. In the last decades, the Brazilian norms and laws to promote accessibility seek to create conditions for people with disabilities to have a more active social and economic life, through the use of universal design precepts in the projects of accessibility for public spaces and mass transports. However, setting regulations and norms has proved insufficient, since the simple standardization of physical resources, such as tactile floors, do not guarantee autonomy for the displacement of visually impaired people. Parallel to the adaptations of public spaces for accessibility, some electronic technologies have been effectively developed for the universal design, amongst them the present forms of audiodescription of TV programs, cinemas and theaters, as well as the development of synthesized voice technologies so that people with visual disabilities can make use of portable smartphones. In this study, in addition to relevant bibliographical research, practical experiments were carried out in controlled and public environments, applying qualitative research techniques for the collection, recording and analysis of information through the observation of volunteers with visual impairment, using a primordial model of equipment with digital voice technology to guide them in three public spaces in the city of São Paulo, comprising a busy subway station, a sidewalk and a public cultural institution. The experiments have shown that visually impaired volunteers can use an appropriate format of audiodescription for orientation and mobility, as long as they are considered peculiarities that relate the visually impaired people walking speed to cognitive processes relevant to hearing and for environmental perception. As a result, this research offers principles for the audionavigation design, through adjustments in audiodescription to include the orientation and mobility concepts, enabling its application in projects of portable electronic interfaces with synthesized voice to guide visually impaired people, seeking an increase in wayfinding autonomy for these people when in public environments and mass transports.
\end{abstract}

Keywords: Urban Mobility. Spatial Orientation. Visual Impairment. Synthesized Voice. Human-computer interface. Audionavigation. 



\section{LISTA DE FIGURAS}

\section{Preceitos teóricos: autonomia, orientação e mobilidade}

Figura 1 - Orientação autônoma: sentir o ambiente com o corpo................................44

Figura 2 - Orientação autônoma: sentir o ambiente com uma bengala ...................45

Figura 3 - Orientação autônoma: utilizar o auxílio de um animal treinado ..........45

Figura 4 - Orientação autônoma: utilizando o auxílio de ajudas eletrônicas .......46

Figura 5 - Exemplo de padronização de modelos para mapas táteis.........................52

\section{Preceitos teóricos: processos cognitivos e suas implicações para o design}

Figura 6 - Modelo de interface humano-máquina

\section{Preceitos teóricos: relações entre som e imagem para o design de informação}

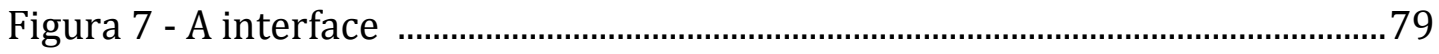

Figura 8 - 0 ouvido humano ............................................................................................. 82

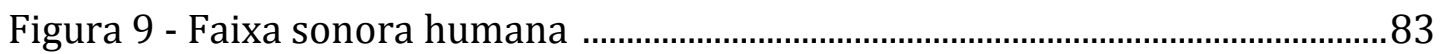

Figura 10 - Frequência e amplitude ........................................................................ 84

Figura 11 - Imagen utilizada na pesquisa de H. Richard Tyler .................................87

Figura 12 - Segregação e a unidade: morfologia espontânea .....................................88

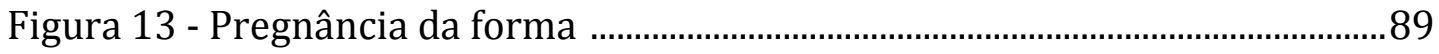

Figura 14 - Representação gráfica de um ruído ambiente ........................................90

Figura 15 - Representação gráfica de uma informação sonora ................................90

Figura 16 - Representação gráfica de uma informação sonora somada

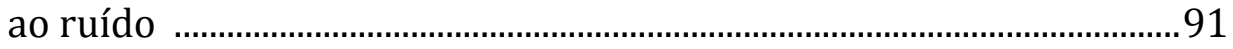

Figura 17 - Representação gráfica de um ruído com grande volume sonoro ......91

Figura 18 - Representação gráfica de informação sonora com volume baixo .....92

Figura 19 - Representação gráfica de informação sonora com um ruído de volume alto

Figura 20 - Exemplos de placas verdes para indicação de direção pelo mundo 95

Figura 21 - Exemplos de placas azuis de indicação de lugares .................................96

Figura 22 - Hierarquia dos componentes sonoros na música .................................98

\section{Preceitos teóricos: orientação por ajudas eletrônicas}

Figura 23 - Exemplo de mapa GPS em tela de smartphone 104 


\section{Procedimentos metodológicos: pesquisas preliminares}

Figura 24 - Percursos do primeiro dia, 21/10/2015

Figura 25 - Percursos do segundo e terceiro dias, 10 e 12/11/2015

\section{Procedimentos metodológicos: audionavegação em ambientes públicos}

Figura 26 - Croqui: plataforma oeste da Estação Vergueiro ................................... 128

Figura 27 - Croqui: mezanino lado oeste da Estação Vergueiro ............................. 129

Figura 28 - Croqui: acesso externo oeste da Estação Vergueiro ............................. 130

Figura 29 - Croqui: rampa para o Centro Cultural São Paulo ................................... 131

Figura 30 - Croqui: Centro Cultural São Paulo (acesso à biblioteca) .................... 132

Figura 31 - Medição de ruído na plataforma da Estação Vergueiro ...................... 137

Figura 32 - Sobreposição do ruído da plataforma no gráfico

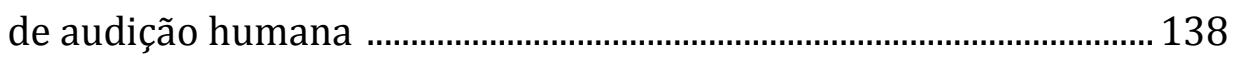

\section{Apêndice E: construções verbais para cada local público}

Figura 33 - Plataforma, porta de saída do trem ....................................................... 205

Figura 34 - Plataforma, sentido norte ............................................................... 205

Figura 35 - Plataforma, porta de saída do trem ........................................................ 206

Figura 36 - Plataforma, sentido escadas de acesso ao mezanino .......................... 206

Figura 37 - Plataforma, sentido elevador .................................................................. 207

Figura 38 - Plataforma, chegada no elevador ........................................................... 207

Figura 39 - Mezanino área paga (dentro dos bloqueios), saída das escadas da

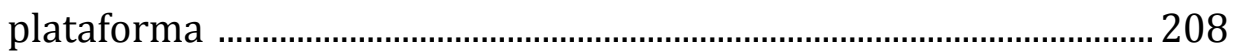

Figura 40 - Mezanino área paga, chegando no piso tátil, à direita, para a saída 208

Figura 41 - Mezanino área paga, saída do elevador ................................................. 209

Figura 42 - Mezanino área paga, curva à direita no piso tátil para a saída ........ 209

Figura 43 - Mezanino área paga, curva à esquerda para a saída ........................... 210

Figura 44 - Mezanino área livre, após os bloqueios ................................................ 210

Figura 45 - Mezanino área livre, bifurcação para os acessos oeste e leste ........ 211

Figura 46 - Mezanino área livre, sentido acesso oeste .............................................. 211

Figura 47 - Mezanino área livre, escadas para o acesso oeste ................................ 212

Figura 48 - Acesso oeste, saídas das escadas do mezanino ...................................... 212 
Figura 49 - Acesso oeste, saída oeste 213

Figura 50 - Rampa de acesso ao Centro Cultural São Paulo 213

Figura 51 - Rampa de acesso ao Centro Cultural São Paulo (ponto 2) 214

Figura 52 - Entrada do Centro Cultural São Paulo - porta oeste 214

Figura 53 - Entrada do Centro Cultural São Paulo - porta leste - os voluntários não usaram 215

Figura 54 - Piso tátil oeste para a biblioteca Louis Braille 215

Figura 55 - Piso tátil leste para a biblioteca Louis Braille - os voluntários não usaram 216

Figura 56 - Junção do piso tátil leste com o oeste para a biblioteca Louis Braille - os voluntários não usaram. 216

Figura 57 - Bifurcação para a biblioteca Louis Braille .. 217

Figura 58 - Entrada da biblioteca Louis Braille 217 



\section{LISTA DE FOTOS}

\section{Preceitos teóricos: autonomia, orientação e mobilidade}

Foto 1 - Mapa tátil instalado na Estação Santa Cecília - Metrô de São Paulo .........50

Foto 2 - Detalhes do mapa tátil da Estação Santa Cecília - Metrô de São Paulo .51

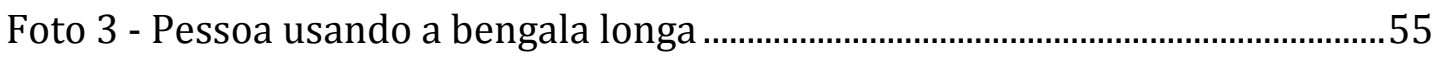

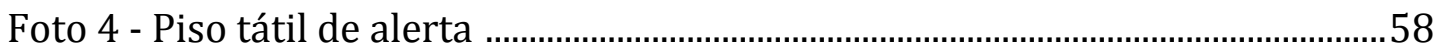

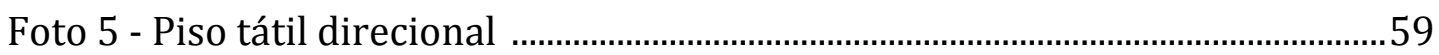

\section{Procedimentos metodológicos: audionavegação em ambientes públicos}

Foto 6 - Escadas que levam da plataforma para o mezanino ..................................133

Foto 7 - Escadas que levam do mezanino para o acesso oeste ............................... 134

Foto 8 - Fones disponibilizados para os voluntários................................................. 138

\section{Resultados: experimentos de audionavegação em espaços públicos}

Foto 9 - Exemplo de earphones com fio

Foto 10 - Voluntário "RB”, mensagem "Esquerda, escadas. Frente,

elevador."

Foto 11 - Voluntária "RC" recebendo a instrução da existência da escada rolante

Foto 12 - Voluntária "RC" decidindo se segue para a escada rolante sem piso tátil

Foto 13 - Voluntária "RC" seguindo para a escada rolante sem piso tátil 157

Foto 14 - Voluntário "RB" em postura corporal para utilizar escadas 157

Foto 15 - Voluntário "RB" saindo da rota antes do tempo 159

Foto 16 - Voluntários "IA" e "EB" saindo da rota antes do tempo 159

Foto 17 - Piso tátil na bifurcação para os acessos 160

Foto 18 - Voluntária “RC" buscando a bifurcação esquerda após a informação por audio

Foto 19 - Voluntária "DA" na bifurcação dos acessos 161

Foto 20 - Usuária distraindo a voluntária "IA" 163

Foto 21 - Rampa de acesso ao Centro Cultural São Paulo 164 
Foto 22 - Centro Cultural São Paulo - piso tátil do portão até a biblioteca Louis Braille 165

Foto 23 - Voluntário "EA" seguindo pelo piso tátil até a porta da biblioteca Louis Braille 166

Foto 24 - Voluntário "RB" seguindo pelo piso tátil até a porta da biblioteca Louis Braille 166

Foto 25 - Voluntário “SE” seguindo pelo piso tátil até a porta da biblioteca Louis Braille 167

Foto 26 - Voluntária "IC" chegando à porta de entrada da biblioteca Louis

Braille 167

Foto 27 - Voluntário “MR", porta de entrada da biblioteca Louis Braille 168

Foto 28 - Voluntária "DA" chegando à porta da biblioteca Louis Braille 168

Foto 29 - Voluntária “RC", porta de entrada da biblioteca Louis Braille 169 


\section{LISTA DE QUADROS}

\section{Preceitos teóricos: Processos cognitivos e suas implicações para o design}

Quadro 1 - Processo da atenção 69

Quadro 2 - Processo da percepção .................................................................................... 70

Quadro 3 - Processo da memória .............................................................................. 71

Quadro 4 - Processo do aprendizado ............................................................................ 73

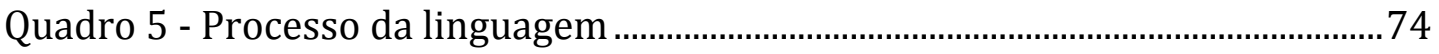

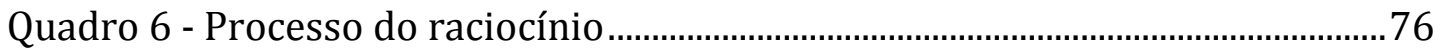

Preceitos teóricos: Relações entre som e imagem para o design de informação

Quadro 7 - Diferentes ondas de frequências .................................................................85

Quadro 8 - Somando frequências e amplitudes do som .............................................86

Quadro 9 - Convenção internacional de cores para o trânsito .................................... 94

Quadro 10 - Analogia das características visual x sonoro ..........................................99

\section{Procedimentos metodológicos: audionavegação em ambientes públicos}

Quadro 11 - Conteúdos verbais da observação prática.

\section{Resultados: experimento prático em local controlado}

Quadro 12 - Escolhas dos convidados sobre os recursos de audio do experimento

Quadro 13 - Respostas dos voluntários sobre utilizar eletrônicos em locais públicos

Quadro 14 - Reconhecimento das instruções "f”e "i" (siga por 20 passos) ....... 150

\section{Resultados: experimentos de audionavegação em espaços públicos}

Quadro 15 - Escolhas das ferramentas para audição da audionavegação .......... 153

Quadro 16 - Escolha do tipo de escada por cada voluntário .................................... 155

Quadro 17 - Ação dos voluntários para a informação de bifurcação para os acessos

\section{Apêndice A: Protocolo das entrevistas semiestruturadas}


Apêndice B: Respostas obtidas nas entrevistas semiestruturadas

Quadro 19 - Respostas do entrevistado “CF” ................................................................. 195

Quadro 20 - Respostas do entrevistado "MC" .............................................................. 196

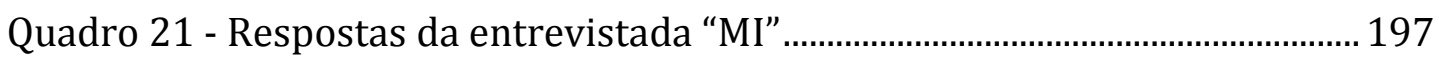

Quadro 22 - Respostas do entrevistado "MK” .............................................................. 198

Quadro 23 - Respostas do entrevistado “RB" ............................................................ 199

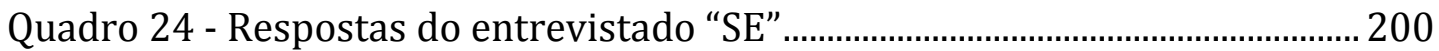




\section{LISTA DE OUTROS ELEMENTOS VISUAIS}

\section{Preceitos teóricos: deficiência visual}

Gráfico 1 - Tipos de deficiência

Preceitos teóricos: Processos cognitivos e suas implicações para o design

Infográfico 1 - Interfaces: necessidades do usuário x subsídios do design .77

Infográfico 2 - Modalidades de processos cognitivos importantes para o design de interfaces para pessoas com deficiência visual .78

Procedimentos metodológicos: audionavegação em locais públicos

Tabela 1 - Cálculo médio de distâncias a percorrer com base no tempo das frases 135

Tabela 2 - Levantamento das experiências com OM dos voluntários 141

\section{Resultados: entrevistas com pessoas com deficiência visual}

Tabela 3 - Opinião dos voluntários sobre o conteúdo da interface vocal 143 



\section{LISTA DE SIGLAS}

ABNT

Associação Brasileira de Normas Técnicas

$\mathrm{AD}$ Audiodescrição

ADEVA Associação para Deficientes Visuais e Amigos $\mathrm{AM}$ Amplitude modulada (modulação do volume dos sons) ASR Automatic Speech Recognition (Reconhecimento Automático de Voz)

CMSP Companhia do Metropolitano de São Paulo - Metrô

GPS Global Positioning System (Sistema de Posicionamento Global)

GUI Graphical User Interface (Interface gráfica)

IBGE Instituto Brasileiro de Geografia e Estatística

IPUF Instituto do Planejamento Urbano de Florianópolis

NBR Regulamento da Associação Brasileira de Normas Técnicas

$\mathrm{OM}$ Orientação e Mobilidade

OMS Organização Mundial da Saúde

ONU Organização das Nações Unidas

PBS Public Broadcasting Service

PDV Pessoa com Deficiência Visual

TTS Text-to-speech (voz digital sintetizada) TV Televisão WHO World Health Organization (Organização Mundial da Saúde) 



\section{SUMÁRIO}

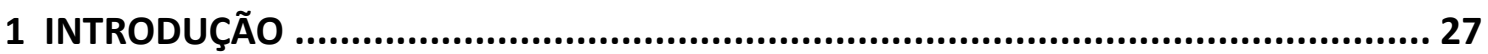

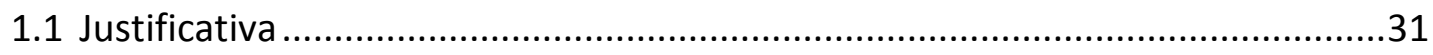

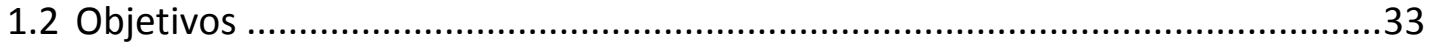

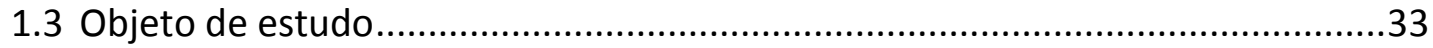

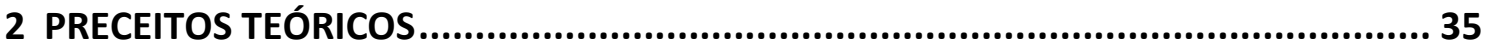

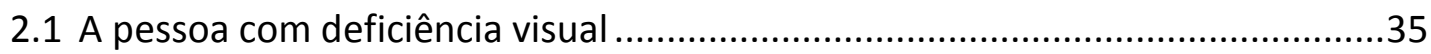

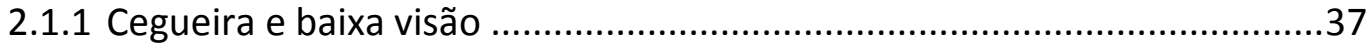

2.1.2 Autonomia, orientação e mobilidade ......................................................38

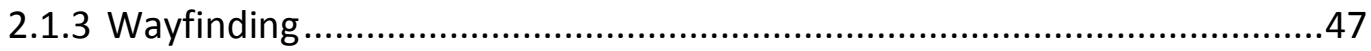

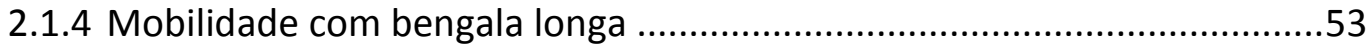

2.1.5 A sinalização tátil de piso (piso tátil) .....................................................57

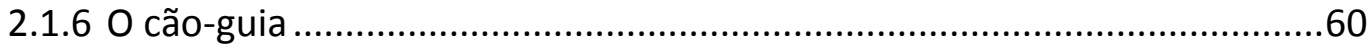

2.2 Processos cognitivos e suas implicações para o design ....................................62

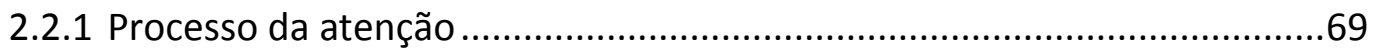

2.2.2 Processo da percepção .......................................................................70

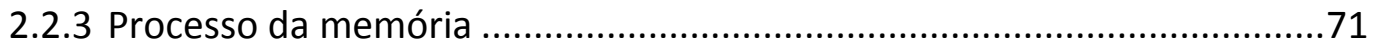

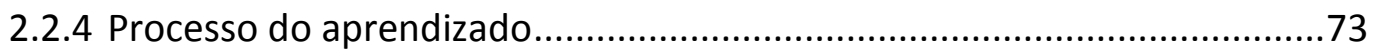

2.2.5 Processo da leitura, fala e audição ......................................................... 74

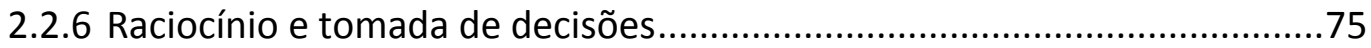

2.3 Relações entre som e imagem para o design de informação ............................79

2.4 Orientação por ajudas eletrônicas ...............................................................100

3 PROCEDIMENTOS METOdOLÓGICOS......................................................... 113

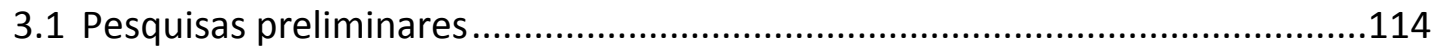

3.1.1 Entrevista com pessoas com deficiência visual .....................................115

3.1.2 Experimento prático em local controlado ..............................................120

3.2 Audionavegação em ambientes públicos ....................................................126

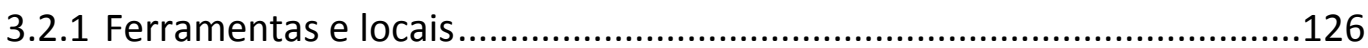


4 RESULTADOS

4.1 Pesquisas preliminares: entrevistas com pessoas com deficiência visual ........143

4.2 Pesquisas preliminares: experimento prático em local controlado .145

4.3 Pesquisa principal: experimentos de audionavegação em espaços públicos...152

5 CONSIDERAÇÕES FINAIS. 171

REFERÊNCIAS 181

APÊNDICE A: PROTOCOLO DAS ENTREVISTAS SEMIESTRUTURADAS 193

APÊNDICE B: RESPOSTAS OBTIDAS NAS ENTREVISTAS SEMIESTRUTURADAS 195

APÊNDICE C: PROTOCOLO DO EXPERIMENTO PRÁTICO EM LOCAL CONTROLADO.. 201 APÊNDICE D: PROTOCOLO DO EXPERIMENTO PRÁTICO EM LOCAIS PÚBLICOS 203

APÊNDICE E: CONSTRUÇÕES VERBAIS PARA CADA LOCAL PÚBLICO 205

APÊNDICE F: TERMOS DE CONSENTIMENTO LIVRE E ESCLARECIDO. 219

Modelo feminino 219

Modelo masculino 222

APÊNDICE G: DISPONIBILIZAÇÃO (INTERNET) DAS FRASES DA AUDIONAVEGAÇÃO 225 


\section{INTRODUÇÃO}

Acessibilidade é um atributo essencial para garantir a melhoria da qualidade de vida das pessoas. Quando os espaços, edifícios, meios de transporte, mobiliário e equipamentos públicos estão adequados ao uso de todas as pessoas, independentemente de sua condição física ou sensorial, entende-se que os projetistas destes recursos fizeram uso da acessibilidade em seus projetos.

Mas a necessidade da acessibilidade vai além dos recursos públicos: o design de produtos e serviços também precisa ser adequado a todos os usuários, inclusive os projetos de tecnologias da informação e comunicação, principalmente quando estas tecnologias podem beneficiar um grande número de pessoas.

As primeiras discussões sobre acessibilidade surgiram no início da década de 1970, nos Estados Unidos da América, para garantir o acesso de pessoas com deficiência às escolas e aos locais de trabalho, o que culminou da criação da Lei Federal da Reabilitação em 1973. As origens dessas discussões derivaram de motivos históricos para a humanidade: os efeitos colaterais causados pela Segunda Guerra Mundial e da guerra no Vietnã, quando muitos soldados retornavam ao país com sequelas psicológicas e físicas.

A iniciativa norte-americana começou a tomar forma ao longo dos anos, sendo então incorporada à agenda da Organização das Nações Unidas (ONU), que iniciou uma discussão mundial sobre acessibilidade e igualdade, salientando a necessidade da igualdade de oportunidades para todas as pessoas, inclusive para pessoas com deficiências, por meio do reexame dos projetos dos ambientes e dos produtos para que todos pudessem utilizá-los, buscando-se assim a sustentabilidade social.

As discussões sobre acessibilidade expõem a necessidade de um trabalho de desenvolvimento de tecnologias que fomente a sustentabilidade social, disponibilizando produtos e serviços que fomentem a inclusão política e social. 0 design está presente em todos os produtos e serviços do dia-a-dia, e a filosofia de design que trata do enfoque em qualquer usuário para a ergonomia dos produtos, independente da condição física ou sensorial do usuário, é o design universal. 
De acordo com a ABNT (2015, p. 139), o design universal, citado como "desenho universal", é um conceito que propõe uma arquitetura e design mais centrados no usuário, estabelecendo critérios para que edificações, ambientes e produtos atendam um maior número de usuários, independentemente de suas capacidades físicas e habilidades.

0 termo Design Universal foi proposto pelo arquiteto norte-americano Ronald Mace na década de 1980 (MACE, 1997). Ronald Mace, que possuía tetraplegia, fundou o Centro para o Design Universal na Universidade da Carolina do Norte, e foi seu diretor até sua morte, em 1998. Segundo Sarraf (2013, p. 63), Ronald Mace conceituou este modelo de design no objetivo de tornar acessíveis os ambientes, produtos e serviços, mas sem quaisquer tipos de segregação e de adequações exclusivas, eliminando indícios de necessidades especiais para o uso destes recursos, propondo um design que atenda o máximo de usuários possível, alavancando, assim, os ideais de inclusão social por meio do convívio de todos os usuários.

O designer que trabalha para a inclusão analisa uma série de questões que normalmente não são abordadas nos projetos comuns, explorando as mais variadas questões de ergonomia e usabilidade ao considerar todas as nuances manifestas nos usuários, pois a filosofia do design universal precisa fazer parte do desenvolvimento dos produtos, desde a embalagem do remédio, por exemplo, tornando possível sua fácil identificação e utilização pelo idoso sem torná-lo disponível para crianças, até o projeto dos ônibus urbanos, que devem ser acessíveis a todas as pessoas, tenham elas deficiência ou não.

Além da readequação de produtos do cotidiano, o design universal também possibilitou a aplicação de tecnologias nunca pensadas, quebrando barreiras que até muito recentemente eram consideradas intransponíveis. Um importante exemplo deste tipo de inovação é a interação entre pesquisas em design universal com a engenharia de materiais de alta performance, tornando possível a concepção de produtos para que pessoas com diversos tipos de deficiências possam praticar atividades esportivas de alto desempenho, culminando nos jogos paraolímpicos, o maior evento mundial para pessoas com deficiência. 
O design universal permite que pessoas com deficiências utilizem produtos e serviços antes projetados pensando-se somente em pessoas sem deficiências. Um exemplo marcante foi o advento dos smartphones, com suas grandes telas lisas, sem teclas físicas, e seu conteúdo exclusivamente gráfico. Devido ao seu modelo de tecnologia, estes aparelhos eram, inicialmente, inacessíveis para pessoas com deficiência visual. No entanto, em poucos anos, os designers desenvolveram ferramentas de uso dos smartphones e suas telas lisas por meio de informações táteis e sonoras para o uso de pessoas com deficiência visual, tornando acessível o inacessível, sem que para isso fosse necessário criar aparelhos diferenciados, tornando os smartphones em evidentes exemplos de design universal.

Devido à natureza subjetiva que envolve a cegueira, a baixa visão e sua relação com outras variáveis de cunho pessoal, a capacidade das pessoas com deficiência visual em se orientar e caminhar em locais públicos ou privados depende diretamente de sua individualidade. Para desenvolver esta capacidade individual, existem técnicas de localização ambiental para caminhar que podem ser adquiridas por meio do ensino em cursos ministrados por instituições especializadas ou de forma autodidata, por meio de experiências próprias. Todas as técnicas desenvolvidas, aprendidas e aprimoradas para que pessoas com deficiência visual possam caminhar em locais públicos são chamadas de técnicas de orientação e mobilidade.

Atualmente, uma considerável parte dos ambientes públicos possuem adequações que se propõem a auxiliar na condução de pessoas com deficiência visual, por meio de recursos que se objetivam a auxiliar estas pessoas a seguirem trajetos em espaços públicos, mesmo sem o uso da tecnologia da eletrônica. 0 recurso mais comum com esta finalidade é o piso tátil, que se constitui da inserção de uma sinalização no piso dos locais públicos, de forma a oferecer um contraste visual e háptico ao longo do caminho, no objetivo de produzir uma trilha a qual as pessoas com deficiência visual possam seguir com a bengala.

Para que as pessoas possam escolher qual caminho seguir, precisam de informações sobre os ambientes ao longo trajeto, utilizando-se de ferramentas que possibilitem escolher as diversas opções ao longo deste caminho, conhecendo previamente os conteúdos das sinalizações visuais e reconhecendo os elementos 
disponíveis nos ambientes que farão parte de seu trajeto, como rampas, escadas, corredores, calçadas e bloqueios. Além disso, as pessoas precisam ser informadas dos serviços disponíveis à sua volta, como a presença de pontos de ônibus e táxi, acessos de estações de trens e metrô e entradas de comércios e edifícios. Esta é a forma natural que as pessoas sem deficiência visual utilizam para seguir um trajeto, usando as informações captadas por meio dos olhos, dentro de seu campo de visão, utilizando estas informações para tomar decisões imediatas sobre qual caminho deve seguir.

Esta forma de seguir um trajeto não pode ser feita por pessoas com deficiência visual, pois as informações disponíveis a elas, muitas vezes, são limitadas a sons, a odores e ao reconhecimento de elementos próximos por meio do tato. Se a pessoa com deficiência visual não possuir familiaridade com o ambiente, a identificação do conteúdo de sinalizações visuais e o reconhecimento da presença de comércios e de serviços públicos precisam ser informados por outras pessoas ao seu redor, cerceando sua autonomia e limitando seu direito à cidadania.

Paralelamente à chegada dos primeiros smartphones, uma nova tecnologia foi tornando-se popular: a navegação pessoal por meio eletrônico, cujo exemplo mais conhecido é o chamado Global Positioning System (GPS1), ou Sistema de Posicionamento Global. Disponíveis inicialmente aos usuários na forma de aparelhos dedicados, de médio porte, com mapas digitais em telas adequadas para o uso em veículos automotores, os sistemas de navegação eletrônica começaram a tornarem-se populares quando os designers integraram esta funcionalidade nos smartphones, aumentando ainda mais a disponibilidade de opções aos usuários destes aparelhos.

No entanto, mesmo em smartphones, os atuais sistemas de navegação pessoal utilizam interfaces digitais predominantemente gráficas, explorando vozes digitais

1 GPS, sigla em inglês para Global Positioning System, é um sistema eletrônico que envolve a localização geográfica por meio de satélites em órbita do planeta Terra (WELLENHOF, LICHTENEGGER e COLLINS, 2013, p. 5). Os aplicativos eletrônicos que mostram a localização por meio de mapas em aparelhos portáteis são popularmente conhecidos por "GPS". 
somente como suplemento às informações mostradas em seus mapas eletrônicos. Quando em dúvidas sobre o caminho a ser percorrido, os usuários que possuem o sentido da visão podem simplesmente olhar a tela do equipamento, ou mesmo observarem os pontos de referência no ambiente, reconhecendo a presença de obstáculos, proibições ou perigos, atenuando assim os riscos no decurso de seu trajeto.

Devido a esta característica predominantemente gráfica, este modelo de utilização dos atuais sistemas de navegação e orientação representa uma importante dificuldade de uso por pessoas com deficiência visual, pois a comunicação gerada pelas vozes digitais fornece somente informações que reforçam o que existe nos mapas gráficos, constituindo-se de informações básicas, dependentes, inadequadas à navegação sem visão. Além disso, as limitações representadas por erros de posicionamento, comuns no GPS, podem fornecer informações discordantes ou conflitantes, tornando-as inúteis ou até mesmo perigosas para pessoas com deficiência visual.

Mesmo apresentando diversas inadequações para o uso de pessoas com deficiência visual, as tecnologias eletrônicas de navegação ainda possuem o potencial para serem aperfeiçoadas. É neste momento que os projetistas podem se valer novamente do design universal, buscando formas de adequar os sistemas eletrônicos de navegação para que todos possam fazer uso das informações, inclusive os usuários com deficiência visual.

\subsection{JUSTIFICATIVA}

A popularização de aparelhos eletrônicos portáteis pode ser um importante aliado na mobilidade de pessoas com deficiência visual, pois seu tamanho reduzido, aliado aos avanços nas interfaces, permite que as pessoas utilizem cada vez mais estes sistemas para sua mobilidade, posto que a aplicação do design universal nos atuais produtos de tecnologia eletrônica contribuiu para a criação de novas tecnologias assistivas.

O piso tátil, aliado às técnicas de orientação e mobilidade, são ferramentas que se propõem a incrementar a segurança para que pessoas com deficiência visual 
possam caminhar pelos espaços públicos. No entanto, apesar da combinação entre estas duas ferramentas fornecerem um importante grau de segurança para a integridade física, é uma combinação imperfeita quando o objetivo é prover a autonomia das pessoas com deficiência visual, pois a autonomia exige que a pessoa tenha informações mais completas que um simples piso diferenciado. Deste modo, a informação precisa estar ao seu alcance das pessoas com deficiência visual, de forma semelhante à informação que seria obtida por meio dos olhos, para que elas possam usufruir de autonomia.

No entanto, a complexidade e a quantidade de informações necessárias para descrever um ambiente ou trajeto torna inconcebível sua incorporação em simples sinalizações mecânicas, como o piso tátil. É neste momento que a tecnologia da eletrônica pode ajudar, possibilitando o empregando outros modos de informar, como a linguagem por voz sintetizada.

A utilização da linguagem para descrever situações às pessoas com deficiência visual já é utilizada como ferramenta de descrição de peças teatrais, shows, filmes em cinemas e em eventos, em um formato chamado audiodescrição. Desta forma, as linguagens por voz são a forma mais completa de transmitir informações, pois, semelhante à visão, a fala pode transportar amplamente uma gama de conhecimentos complexos, muito além de simples sinalizações táteis.

Seguindo esta linha de raciocínio, a audiodescrição pode ser ampliada para a descrição dos elementos dos ambientes durante o percurso de uma pessoa com deficiência visual em locais públicos, por meio de um formato readequado, com a finalidade de informar sobre o ambiente que a pessoa está imersa. Para isso, tornase importante um estudo de design universal, buscando-se formas confiáveis para realizar a audiodescrição de trajetos, fornecendo subsídios para que o designer de interface possa aperfeiçoar as informações por áudio no objetivo de oferecer um formato pleno de audiodescrição que possibilite a eliminação da informação visual.

Além disso, a audiodescrição dos ambientes pode ser mais bem aproveitada se for disponibilizada diretamente para a pessoa interessada, sem interferir com os sons que outras pessoas estão utilizando. Desta forma, a melhor opção para disponibilizar a audiodescrição dos ambientes para a pessoa seguir um trajeto, em 
uma audionavegação confiável e autônoma, é fornecer esta audionavegação por meio de aparelhos portáteis, como o smartphone, fomentando a autonomia com segurança da pessoa com deficiência visual.

No entanto, os princípios gerais do design privilegiam os aspectos visuais, tornando escassos os estudos e a bibliografia de aspectos sonoros e vocais que possam ser utilizados em produtos para pessoas com deficiência visual. Portanto, esta pesquisa se mostra necessária para estabelecer parâmetros para o design de interface vocal sintetizada para navegação eletrônica em um modelo específico de audiodescrição que possa ser incorporada em aparelhos eletrônicos portáteis para audionavegação, de modo a fornecer autonomia com segurança para que pessoas com deficiência visual possam utilizá-los para seguir trajetos em espaços públicos e transportes de massa.

\subsection{OBJETIVOS}

O objetivo principal desta pesquisa é estabelecer princípios para o design de navegação por áudio, ou audionavegação em ambientes públicos para pessoas com deficiência visual. Para isso, será necessário investigar padrões comportamentais e cognitivos de pessoas com deficiência visual, enquanto são guiadas em locais públicos por equipamento eletrônico que emprega construções verbais por meio de voz sintetizada para orientação e mobilidade, identificando-se características de usabilidade e compreensão das instruções vocais por meio da observação das pessoas do grupo experimental em ambientes públicos selecionados.

\subsection{OBJETO DE ESTUDO}

O objeto deste estudo são as pessoas com deficiência visual usuárias de audionavegação por voz sintetizada para orientá-las a partir de uma origem até um destino, em um trajeto realizado em ambientes compostos por uma estação de transporte metroviário e por espaços públicos abertos e fechados. 



\section{PRECEITOS TEÓRICOS}

A investigação bibliográfica, análoga à pesquisa em profundidade, teve por objetivo a obtenção dos conhecimentos sobre aspectos do design para o desenvolvimento de interfaces eletrônicas que empregam construções verbais para a audionavegação que possam ser utilizadas por usuários com deficiência visual.

A categorização dos segmentos da base bibliográfica possibilitou a obtenção de diretrizes para a condução das pesquisas práticas, conforme Bardin (1979, p. 30), Minayo e Sanches (1993, p. 241), buscando a correta quantificação dos temas concernentes à complexidade da investigação.

Desta forma, a pesquisa bibliográfica possui dois grandes grupos. 0 primeiro grupo, compondo-se dos capítulos 2.1 e 2.2, engloba as informações sobre pessoas com deficiência visual e as particularidades relacionadas à sua autonomia na mobilidade em espaços públicos. O segundo grupo, compondo-se dos capítulos 2.3 e 2.4, engloba os princípios do design, abrangendo uma relação dos aspectos visuais e auditivos, convergindo para o design de sinalização, e finaliza com aspectos do design de interfaces eletrônicas para orientação e mobilidade, as chamadas ajudas eletrônicas.

\subsection{A PESSOA COM DEFICIÊNCIA VISUAL}

A palavra "deficiente" pode conter um significado intrínseco muito forte, pois carrega conceitos de valores morais opostos à palavra "eficiente". Ao se enfatizar indevidamente a falta ou limitação de algumas pessoas, pode ocorrer uma suposição a qual pessoas com deficiência não são capazes e necessitariam de assistencialismo ou paternalismo (LARA e ALTHAUS, 2009, p. 10). Esta postura assistencialista não poderia ser mais incorreta, pois a incapacidade de pessoas com deficiência em realizar determinadas tarefas não está relacionada ao que falta em seu corpo, está relacionada às condições impróprias do ambiente. Em um trecho da Convenção Sobre a Pessoa com Deficiência (BRASIL, 2012, p. 9), há um resumo sobre as principais dificuldades de mobilidade às pessoas com deficiência, que se aplica às pessoas com deficiência visual, posto que não é o limite individual que 
determina a deficiência, mas sim as barreiras existentes nos espaços, no meio físico, no transporte, na informação, na comunicação e nos serviços.

Segundo o Instituto Brasileiro de Geografia e Estatística - IBGE (2012), 24\% da população acima de dez anos de idade, o equivalente a aproximadamente 45 milhões de pessoas, relata ter algum tipo de deficiência, e a deficiência visual acomete a maior parte desta parcela da população, com 78\% destas pessoas declarando ter deficiência visual (gráfico 1).

\section{Gráfico 1 - Tipos de deficiência}

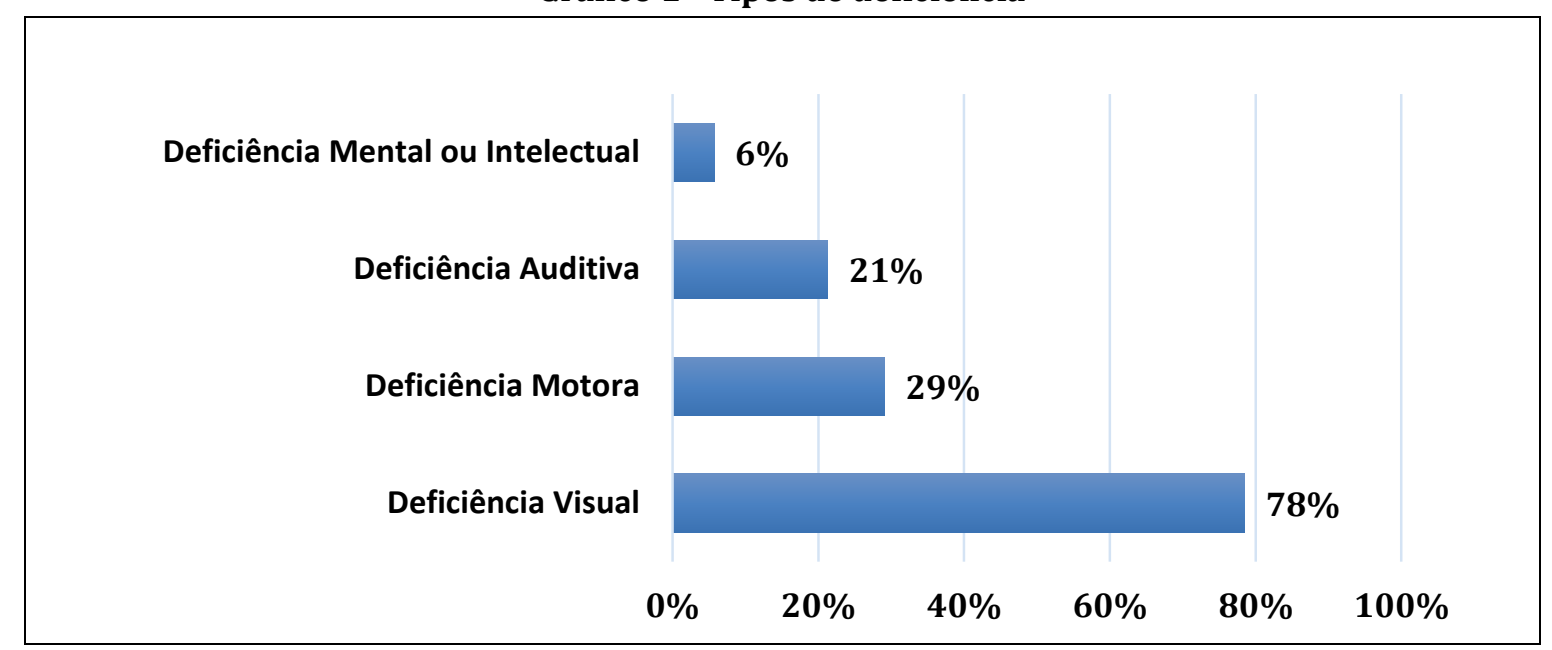

Fonte: do autor, com base nos dados do IBGE (2012)

Segundo Smith (2008), para que as pessoas possam enxergar, quatro elementos são necessários: a luz, o objeto que reflete a luz, os olhos para sentirem e transformarem a luz em sinais elétricos, e a parte do cérebro para processar e dar significado aos sinais recebidos dos olhos. Se um ou mais destes elementos inexistirem, a pessoa não será capaz de enxergar.

As pessoas que possuem a capacidade de enxergar luz, formas e contornos de objetos a são comumente chamadas "videntes". As pessoas que não possuem a capacidade de enxergar luz, formas e contornos de objetos, seja por características congênitas ou que tenham perdido a visão após certo tempo de vida, são chamadas "pessoas com deficiência visual", termo este utilizado em documentações técnicas e regulatórias sobre o assunto, e constantemente abreviado para "PDV" (MANSINI, 1993, p. 61; BRUMER, PAVEI e MOCELIN, 2004, p. 305). 


\subsubsection{CEGUEIRA E BAIXA VISÃO}

Deficiência visual é o termo que define a perda na acuidade visual ${ }^{2}$, desde que esta perda não possa ser corrigida por intermédio de lentes ou de intervenção cirúrgica (MOURA e PEDRO, 2006, p. 221).

Existem dois tipos de deficiência visual, a cegueira e baixa visão, e a definição de ambos os termos é muito subjetiva. Uma das definições de cegueira é "uma alteração grave ou total de uma ou mais funções elementares da visão que afeta de modo irremediável a capacidade de perceber cor, tamanho, distância, forma, posição ou movimento em um campo mais ou menos abrangente" (SÁ, CAMPOS e SILVA, 2007, p. 15).

A definição de baixa visão, também chamada de visão subnormal ou visão residual, é algo ainda mais complexo, pois envolve as relações entre os diversos tipos de comprometimento visual com a intensidade deste comprometimento (SÁ, CAMPOS e SILVA, 2007, p. 16), podendo englobar níveis de visão desde a simples percepção de luz até capacidade limitada de acuidade ou do campo visual, limitando o desempenho de execução de tarefas relacionadas à visão (SILVEIRA, 2010, p. 41).

No Brasil, o limiar tecnicamente definido para se reconhecer a cegueira do indivíduo, para fins político-sociais, é definido pelo decreto presidencial 5296, de 02 de dezembro de 2004, da seguinte forma:

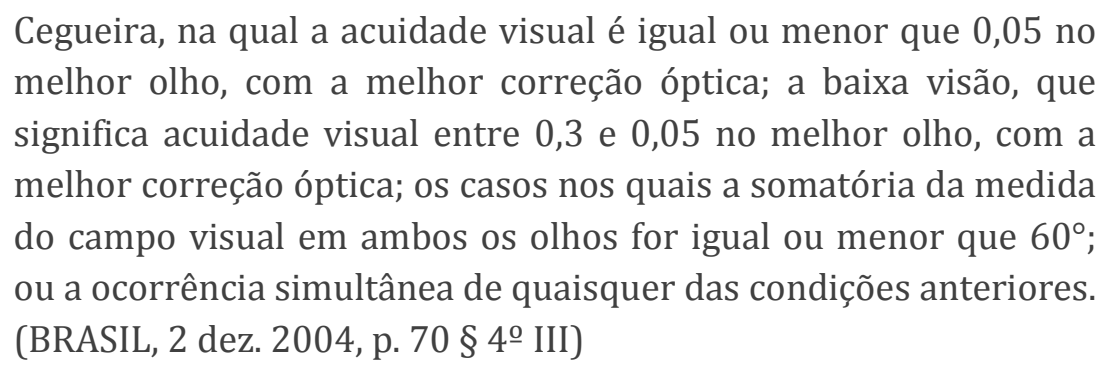

Uma deliberação aproximada, embora com parâmetros ligeiramente diferentes, foi determinada pela reunião sobre deficiência visual infantil da Organização Mundial da Saúde em 1992, que define que pessoa com baixa visão é a que possui o

\footnotetext{
${ }^{2}$ Acuidade visual é a capacidade de o indivíduo perceber, por meio dos olhos, o contorno e a forma dos objetos (KULPA, 2009, p. 58).
} 
comprometimento de sua capacidade visual, mesmo após utilizar a melhor correção óptica, que possibilite a acuidade visual inferior a 0,33 , ou um campo visual inferior a $10^{\circ}$ a partir de seu ponto central de fixação, mas que permite a capacidade parcial de utilizar a visão para o planejamento ou a execução de tarefas (WHO, 1992, p. 3).

Outra variável a ser considerada sobre deficiência visual é quanto ao momento da vida da pessoa que a deficiência ocorreu. Quando a deficiência visual surge do nascimento até os dois anos de idade, é considerada congênita, e acima dos dois anos de idade, é considerada adquirida. Esta definição é importante porque, após os dois anos de idade, a pessoa pode reter memórias que diferenciam a percepção sensorial. É a chamada memória visual (MOTA e ROMEU FILHO, 2010, p. 77).

\subsubsection{AUTONOMIA, ORIENTAÇÃO E MOBILIDADE}

De acordo com Araújo, Cândido e Leite (2009, p. 40), quando os espaços públicos são planejados de acordo com os preceitos do design universal, temos o estímulo ao incremento da qualidade de vida das pessoas com deficiência, pois a adequação dos espaços públicos, incluindo-se os diversos meios de transporte, tornou-se essencial à independência destas pessoas. Os recursos que podem ser incorporados ao design universal para adequar os espaços para as pessoas com deficiência fazem parte de um conceito chamado tecnologia assistiva ${ }^{3}$ (MANSINI, 1993; NUNES, DANDOLINI e SOUZA, 2014, p. 3).

De acordo com Hannah e Covinton (1997, p. 4), as deficiências somente são uma limitação quando existem barreiras, e o design universal é a forma inclusiva de projetar que deve possibilitar a todos o acesso a tudo por todo o tempo. Este conceito vai ao encontro do texto da Organização Mundial da Saúde, que recomenda a abordagem proativa por meio da universalidade dos projetos, ao

\footnotetext{
${ }^{3}$ De acordo com o Comitê de Ajudas Técnicas da Subsecretaria Nacional de Promoção dos Direitos da Pessoa com Deficiência, tecnologia assistiva é uma área do conhecimento, de característica interdisciplinar, que engloba produtos, recursos, metodologias, estratégias práticas e serviços que objetivam promover a funcionalidade, relacionada à atividade e participação de pessoas com deficiência, incapacidades ou mobilidade reduzida, visando autonomia, independência, qualidade de vida e inclusão social (BRASIL, 2009, p. 9).
} 
invés da abordagem reativa, representada por simples adaptações (OMS, 2012, p. 186).

De acordo com Kastrup (2008, p. 70), quando executamos uma ação automática, não prestamos atenção na atividade, possibilitando o emprego da atenção em outras atividades. Para Santos e Castro (2013, p. 30) a orientação e a mobilidade fazem parte da rotina de todas as pessoas, são atividades quase automáticas e independem da existência de restrições, pois todos precisam deslocar-se de um lugar ao outro por meio de referências que permitam que as pessoas se orientem e encontrem o trajeto a ser percorrido.

Assim, para uma pessoa vidente a atividade de seguir um trajeto habitual em um local público é automática e consome pouco de sua atenção, pois a informação visual proporciona a tomada de decisão com antecedência, com pouca participação da atenção. Esta forma de ação não é tão automática para pessoas com deficiência visual, pois a ausência da visão exige o aumento da participação da atenção para identificar as características do trajeto por meio dos sentidos não visuais, que possuem naturalmente um alcance limitado quando comparados ao sentido da visão. Para facilitar a ação de reconhecer trajetos sem a necessidade da visão, fazse necessário desenvolver as habilidades cognitivas por meio do aprendizado de técnicas de orientação e mobilidade, conhecidas pela sigla "OM", seja por meio autodidata ou por ensino ministrado em instituições especializadas, adequando-se as características e experiência individuais ao método de aprendizado (FELIPPE e FELIPPE, 1997; FELIPPE, 2001; GARCIA, 2003; LORA, 2003; MASI, 2003).

Devido às características predominantemente visuais dos recursos disponíveis nas cidades, as pessoas com deficiência visual podem ter dificuldades para caminhar nos ambientes públicos. De acordo com Furrer (2012), quando não são corretamente planejados, os espaços públicos dificultam a locomoção de pessoas com deficiência visual, pois apresentam obstáculos de difícil percepção pelos sentidos não visuais. Estes obstáculos fazem parte das chamadas barreiras físicas ou arquitetônicas.

Para minimizar ou eliminar estas barreiras, os elementos ambientais, como edifícios, calçadas, transportes, informação e comunicação, precisam ser 
devidamente integrados, modificados e regularizados, na busca pela adequação à acessibilidade. Um ambiente acessível traz benefícios que abrangem uma grande variedade de pessoas. Um sistema de comunicação nas paradas de transportes de massa, projetado inicialmente para pessoas com deficiência visual, pode beneficiar também outras pessoas que não estão familiarizados com as linhas de ônibus do local, independentemente de possuírem algum tipo de deficiência (MARIANI, 2016, p. 245). Assim, pode-se fornecer a acessibilidade necessária para todas as pessoas, independente de quaisquer limitações físicas, mentais ou sensoriais.

Assim, para fomentar a autonomia na mobilidade em espaços públicos para as pessoas com deficiência visual, é preciso conhecer alguns fatores que possam ser usados no desenvolvimento de soluções complementares às já utilizadas no planejamento dos espaços públicos. Dentre estes fatores pode-se citar o design com base nos processos cognitivos, as técnicas de orientação e mobilidade e o wayfinding, além dos próprios recursos que já existem, como o guiamento por pessoa vidente, a bengala longa, o cão-guia, a sinalização tátil de piso e, finalmente, as ajudas eletrônicas.

De acordo com Harper (1998, p. 36) e Baxter (2011, p. 48), a percepção humana é amplamente dominada pela visão, pois a visão predomina sobre os demais sentidos. Assim, é comum que os projetos de ambientes, veículos e objetos considerem a capacidade sensorial da visão para serem utilizados. Existem diversos exemplos de equipamentos projetados para o wayfinding, como placas de indicação de locais e direções, mas também temos ferramentas importantes que provêm segurança às pessoas, como sinalizações semafóricas, faixas de pedestres, alertas de teto baixo, etc. A maioria destes exemplos é projetada para que pessoas as identifiquem com o sentido da visão. Por não terem acesso às informações visuais necessárias à percepção destes objetos, as pessoas com deficiência visual possuem grandes desvantagens quanto à identificação dos espaços.

Montello e Sas (2006, p. 3) afirmam que a orientação espacial, juntamente com a habilidade pessoal em determinar sua localização no ambiente, define o processo necessário para que as pessoas possam atingir um destino a partir de sua posição atual. No entanto, segundo Espinosa et al. (1998, p. 1) e Liben (1998), a ausência 
de demarcações e referências perceptíveis às pessoas com deficiência visual dificulta a compreensão sobre o layout, direção e orientação dentro de ambientes amplos, prejudicando sua capacidade de mover-se de maneira rápida, eficiente e independente, porque dependem de um processo cognitivo formado pela percepção, codificação, aprendizagem e memorização das informações sobre o ambiente, processo este que, em um primeiro momento, está ausente.

Brito (2009, p. 61) afirma que a área de maior importância para a pessoa com deficiência visual é a mobilidade, especialmente para as pessoas que adquiriram a cegueira, devido à carga psicológica extremamente negativa da sensação recente de perda. As pessoas acometidas pela deficiência visual após a idade adulta frequentemente acreditam que, de certa forma, o mundo acabou para eles, pois sua percepção é a de que o conhecimento sobre o ambiente que a rodeia dependente da visão. No entanto esta percepção é distorcida, pois a pessoa com deficiência visual pode aprender a caminhar sozinha, bastando dispor de coragem, desinibição e do conhecimento de técnicas de orientação e mobilidade.

De acordo com Santos e Castro (2013, p. 7), existem famílias de pessoas com deficiência visual que, por medo ou desconhecimento sobre a deficiência, agem de forma a superproteger seus entes, incentivando constantemente o uso do guia vidente.

De acordo com Felippe (2001), o guia vidente é um recurso comum em diversas situações no dia-a-dia da pessoa com deficiência visual. Quando a pessoa com deficiência visual é auxiliada por guia vidente, seja este um profissional, um familiar, um amigo, qualquer pessoa que ofereça ajuda, há um considerável incremento na segurança, pois a informação visual torna-se disponível por meio dos olhos do acompanhante.

No entanto, Moraes e Arendt (2011, p. 116) afirmam que, se a pessoa com deficiência visual faz uso de guia vidente de forma constante, o reconhecimento do local, de fontes de sons e da direção torna-se ineficaz, dificultando a autonomia na orientação e mobilidade, concordando com Felippe (2001), que reconhece a necessidade de cuidados no uso de guia vidente de forma a garantir algum grau de controle, decisão e de participação da pessoa com deficiência visual durante o seu 
deslocamento, evitando assim a perda da percepção de autonomia, pois, de acordo com Casals (2007, p. 35), a presença constante do acompanhante pode ser uma distração, abrandando a familiarização com o ambiente.

De acordo com Silveira (2010, p. 62), orientação é a capacidade de utilizar os sentidos disponíveis para obter informações sobre o ambiente, aprendendo a reconhecer padrões que permitam identificar onde a pessoa está, para onde quer ir e como fazer para chegar ao lugar desejado. Para tornar possível a mobilidade, é fundamental o aprendizado da orientação, tornando organizado e eficaz o controle dos movimentos. Para isso, as pessoas com deficiência visual precisam aprender a utilizar os sentidos disponíveis, como a audição, o tato, a cinestesia, o olfato e, se for o caso, a visão residual.

Nos estudos realizados por Hoffmann (1998, p. 152), diversos são os benefícios que a pessoa com deficiência visual pode ter com o treino de orientação e mobilidade, tais como autoconfiança, integração, contato social e oportunidade de emprego. Santos e Castro (2013, p. 7) também afirmam que o domínio e o manejo dos recursos e técnicas de orientação e mobilidade promovem o autoconhecimento e o conforto diante das dificuldades, proporcionado à pessoa com deficiência visual um sentimento de reconquista e de autoconfiança, incrementando a segurança em sua potencialidade por meio do exercício de suas habilidades motoras e cognitivas, bem como o aprendizado para lidar com suas limitações. Assim, o uso de guia vidente é importante para a segurança, mas a sua presença prejudica a autonomia, caso seja este o objetivo da pessoa com deficiência visual.

O ensino das técnicas de orientação e mobilidade foi iniciado em 1957 no Brasil, pela Fundação do Livro do Cego, com consultoria de Joseph Albert Ansejo, enviado da Royal School of Industries for the Blind, quando seu superintendente, Ernest Harold Getliff, sugeriu o treinamento como uma das medidas necessárias para diversos problemas encontrados sobre pessoas com deficiência visual no Brasil (FELIPPE e FELIPPE, 1997). 
A combinação do conceito de orientação com o conceito de mobilidade pode ser feita da seguinte forma:

Orientação é a habilidade do indivíduo em estabelecer as relações corporais, espaciais e temporais para perceber o ambiente que o cerca e, para a pessoa com deficiência visual, esta habilidade é alcançada por meio da utilização da audição, do aparelho vestibular, do tato, da consciência cinestésica, do olfato e da visão residual, nos casos de pessoas com baixa visão, enquanto a mobilidade é a capacidade ou estado inato do indivíduo para se locomover reagindo a estímulos internos ou externos, em equilíbrio estático ou dinâmico (FELIPPE e FELIPPE, 1997).

[...] a expressão "orientação e mobilidade" significa mover-se de forma orientada, com sentido, direção e utilizando-se de várias referências como pontos cardeais, lojas comerciais, guia para consulta de mapas, informações com pessoas, leitura de informações de placas com símbolos ou escrita para chegarmos ao local desejado. (GIACOMINI, SARTORETTO e BERSCH, 2010, p. 7).

As técnicas de orientação e mobilidade também preveem o ensino da proteção contra situações de riscos ambientais, normalmente contra riscos mecânicos. Segundo DeCastro, Paula e Tavares (2004, p. 203), é importante que as pessoas com deficiência visual possam evitar os riscos de colisão com objetos durante a navegação. Para Felippe (2001, p. 10), o ensino de técnicas que evitam ou minimizam os efeitos de colisões é chamado de técnicas de orientação com o próprio corpo. São técnicas complementares à orientação e mobilidade com linha guia ou bengala, com cão-guia e com ajudas eletrônicas, constituindo-se, fundamentalmente, em formas de se proteger, de estabelecer relações posicionais e direcionais e de fazer contato com objetos e pessoas, traduzindo-se em maior controle da pessoa com deficiência visual sobre seu próprio corpo e seus movimentos. Por este motivo, durante a navegação, as pessoas com deficiência visual que têm treinamento de orientação e mobilidade buscam manter livre uma das mãos, deixando-a disponível para situações de risco, enquanto a outra faz uso das tecnologias assistivas, como a bengala longa. 
Para Barbosa (2015, p. 37) o ensino de técnicas de orientação e mobilidade oferecem condições para que as pessoas com deficiência visual possam desenvolver a capacidade de se orientar e se movimentar em diversas condições e diversos ambientes, ao adequar o ensino aos fatores pessoais como o tipo da deficiência, idade, experiências, necessidades e interesses.

Sendo o conceito de orientação e mobilidade parte da rotina diária das pessoas, independentemente se videntes ou com deficiência visual, a capacidade de se orientar para atingir o destino depende de referências conhecidas acerca do caminho a ser seguido, e as pessoas com deficiência visual podem suprir a ausência da percepção visual por intermédio de ferramentas que fazem uso das outras referências sensoriais.

Dentre as ferramentas possíveis para que as pessoas com deficiência visual possam se orientar de forma autônoma, Felippe (2001, p. 3) cita quatro mais comuns:

1) usando seu próprio corpo para sentir hapticamente o ambiente (figura 1).

Figura 1 - Orientação autônoma: sentir o ambiente com o corpo

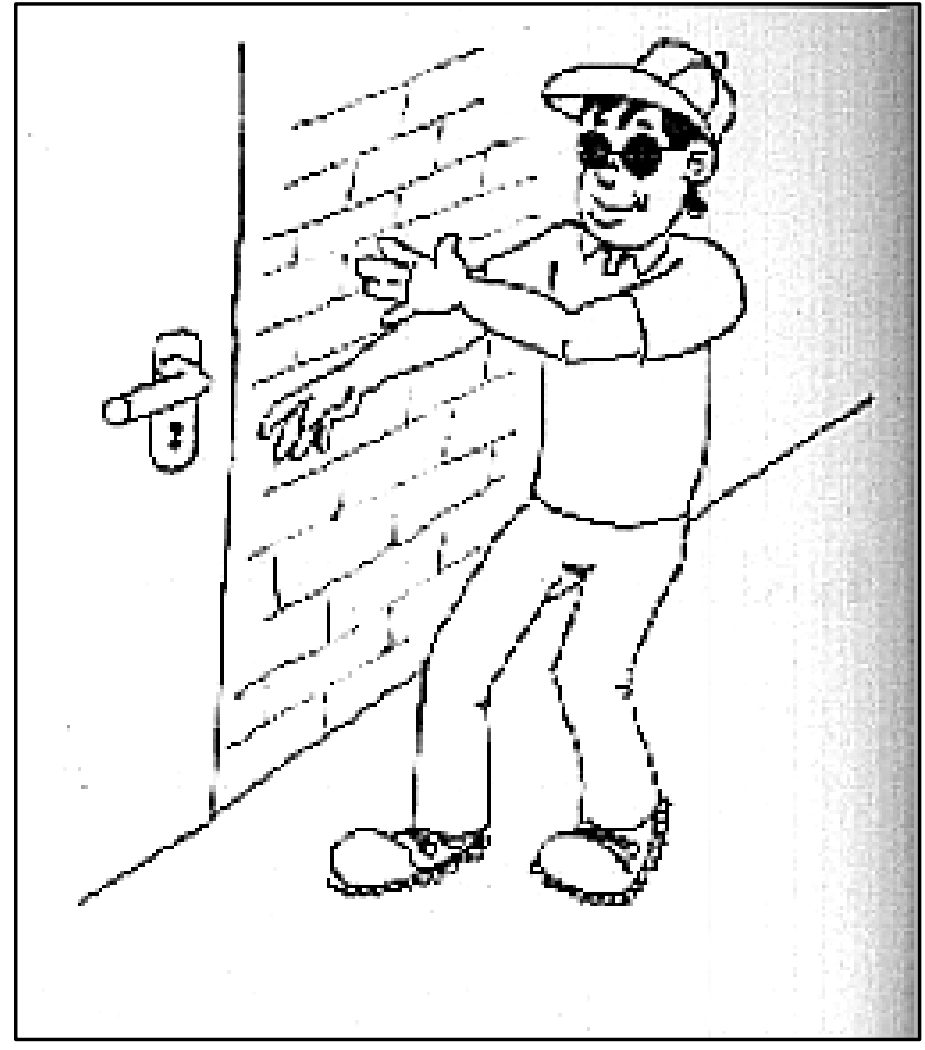

Fonte: Felippe (2001, p. 3) 
2) usando uma bengala que transmita sensações hápticas sobre o caminho a sua frente para sua mão (figura 2).

Figura 2 - Orientação autônoma: sentir o ambiente com uma bengala

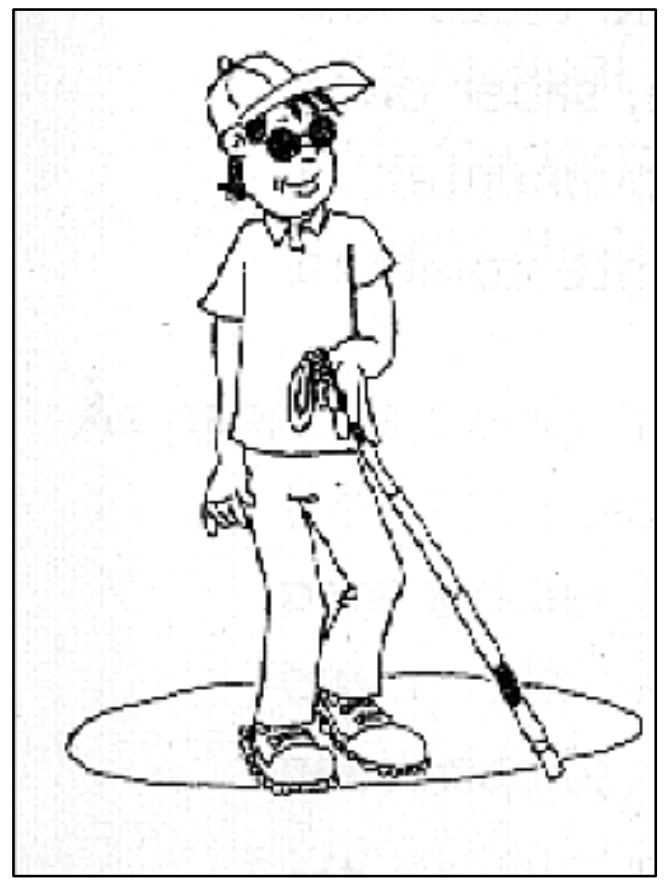

Fonte: Felippe (2001, p. 3)

3) utilizando o auxílio de um animal treinado (figura 3).

Figura 3 - Orientação autônoma: utilizando o auxílio de um animal treinado

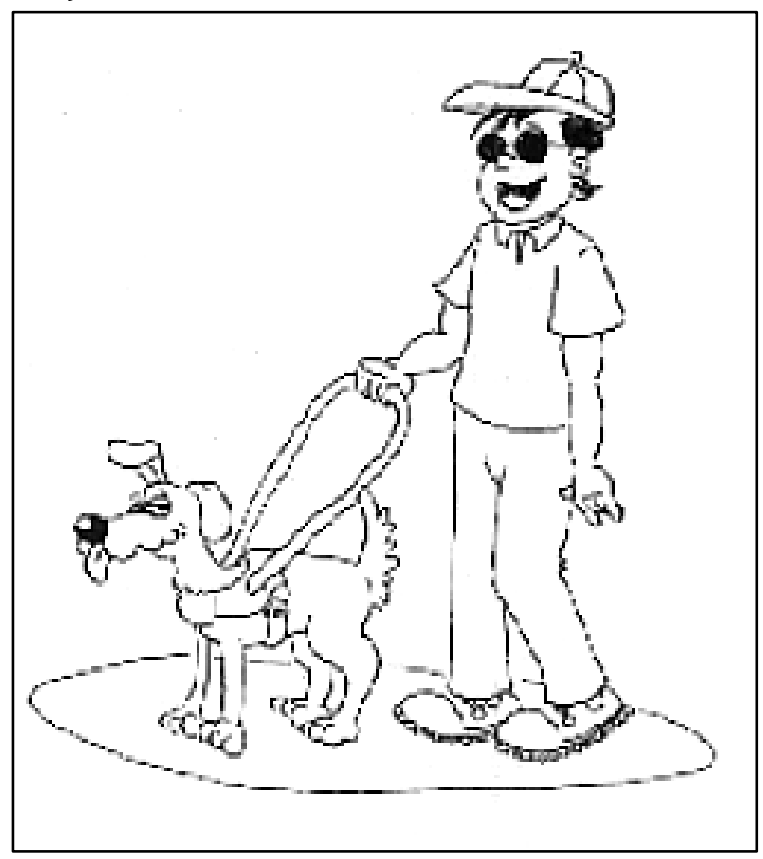

Fonte: Felippe (2001, p. 3) 
4) utilizando o auxílio de ajudas eletrônicas (figura 4).

Figura 4 - Orientação autônoma: utilizando o auxílio de ajudas eletrônicas

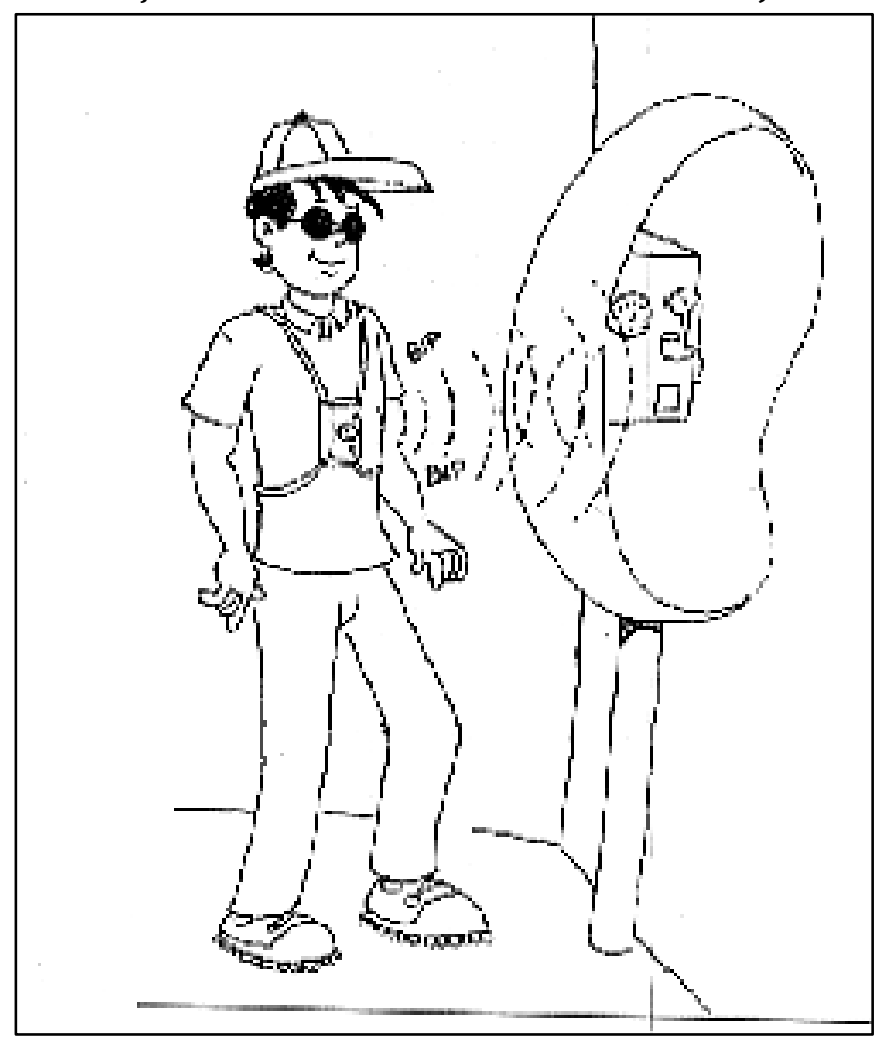

Fonte: Felippe (2001, p. 3)

O uso das ferramentas de orientação e mobilidade proporcionam a percepção de pontos de interesse para formar trajetos ao longo dos ambientes, fornecendo às pessoas com deficiência visual a capacidade de deslocamento de uma origem até um destino por meio do reconhecimento destes pontos de interesse. 0 processo que envolve a navegação por meio do uso de informações acerca de pontos de interesse identificáveis nos ambientes, possibilitando o deslocamento das pessoas até um destino desejado, é chamado de wayfinding. 


\subsubsection{WAYFINDING}

A capacidade das pessoas de caminhar pelos ambientes ocorre de forma natural, por meio do reconhecimento de pontos de referência, e cada ambiente tem peculiaridades que refletem nos tipos de ponto de referência sob seu domínio. Em áreas abertas, os pontos de referência podem ser edifícios, casas, lojas, estações de metrô, pontos de ônibus, etc. Em áreas fechadas, as referências são, predominantemente, objetos de menor escala, como mesas, balcões, vasos de plantas, muretas, paredes, móveis, etc. Os pontos de referência, tanto de áreas externas quanto as áreas internas, possuem uma característica comum: as pessoas as identificam mais facilmente, em tamanho, forma e localização, quando utilizam o sentido da visão.

Para Apelt, Crawford e Hogan (2007, p. 1), wayfinding está associado com a comunicação eficaz sobre determinado trajeto, por meio de uma sucessão de pistas percebidas pelos nossos sentidos da visão, audição, tato e olfato, e cada pista associadas a elementos específicos dos ambientes: para a visão, os ambientes oferecem a arquitetura e a gráfica; para a audição, os sons característicos; para o tato, os elementos tocáveis; e para o olfato, pistas aromáticas, como cafés, restaurantes, presença de plantas aromáticas e flores. Para pessoas com deficiência visual, Apelt, Crawford e Hogan afirmam a extrema importância das pistas sonoras e aromáticas durante a navegação em ambientes públicos, e em segunda importância as pistas táteis, que exigem, em sua maioria, a proximidade com o objeto.

O termo "navegação" difere de "orientação", pois o ato de navegar é seguir uma rota, trajeto, caminho ou curso até um destino específico, enquanto orientar está relacionado a posicionar-se em uma determinada direção, independentemente do destino (BAKER, 1982, p. 5). Esta informação assemelha-se à de Monico (2000, p. 19), ao afirmar que o ato de saber ir e voltar de um local a outro e determinar posições geográficas, seja em terra ou no mar, atribui-se o nome de "navegar".

Baker (1982, p. 4) cita que "navegação" é um termo que surgiu para designar a posição e o curso de navios ou aviões por meio da combinação de geometria e astronomia. Em um contexto moderno, navegação é o termo que caracteriza o 
método de conduzir uma pessoa ou algo até um destino, independentemente do meio. Até mesmo a rota ou direção em meios virtuais, como a ação de encontrar caminhos até um destino dentro da internet, é chamada "navegar".

Segundo Foltz (1998, p. 59) navegar significa mover-se em um espaço, seja este físico, como um ambiente público ou privado, ou virtual, como na internet ou entre as páginas de um livro. A navegabilidade está associada à possibilidade de a pessoa mover-se com êxito no espaço, a partir da sua localização atual até um destino estabelecido, mesmo que a localização deste destino seja pouco conhecida. Foltz cita três princípios do design de espaços que determinam a navegabilidade de um espaço (FOLTZ, 1998, p. 59-69):

- O primeiro critério está associado à capacidade da pessoa para descobrir ou inferir sua localização atual. Este critério diz respeito à recuperação bemsucedida da sua atual localização, que é a origem do percurso. Este conhecimento está associado à capacidade de responder corretamente às questões "onde estou?" e "para que lado eu estou?" com respostas concretas e definitivas, como "estou na saída do edifício, de frente para o ponto de táxi".

- O segundo critério está associado à capacidade de encontrar uma rota para o destino. Este critério é fundamental para a capacidade de realizar com êxito a tarefa de wayfinding, e está associada à correta tomada de decisão que levará a pessoa da sua localização atual ao seu destino. Pode-se citar como exemplos de tomadas de decisão a capacidade de a pessoa decidir se continua em frente no trajeto, se deve virar à direita ou à esquerda em uma bifurcação ou se deve retornar, e até mesmo se precisa parar e encontrar mais informações sobre o caminho para confirmar se o trajeto está correto. Arthur e Passini (1992) citam este processo de resolução de problemas como fundamental para wayfinding. 
- 0 terceiro critério está associado à navegabilidade, que se refere ao acúmulo de experiências da pessoa sobre o trajeto e os espaços durante a navegação, o que permite a criação de mapas mentais ${ }^{4}$ que familiarizem as pessoas com o trajeto. 0 urbanista norte americano Kevin Lynch investigou a relação das características de um espaço urbano com a capacidade das pessoas de se lembrarem destas características (LYNCH, 1960). Lynch entrevistou moradores de Boston, Los Angeles e Nova Jersey, pedindo-lhes para desenhar esboços de mapas de suas cidades usando somente a memória. Lynch comparou os esboços dos mapas, as entrevistas e o mapa real destas cidades, descobrindo que os voluntários usavam um conjunto de características comuns, como caminhos, pontos de referência, locais específicos, esquinas e intersecções para a memorização da cidade.

Loomis, Klatsky e Golledge (2001, p. 282) citam que a navegação, tanto humana como de quaisquer espécies, abrange duas formas distintas: navegação por pontos de referência e navegação por integração de trajeto. Na navegação por pontos de referência, as pessoas utilizam os sentidos sensoriais de visão, olfato, tato e audição, associando referências existentes no ambiente com mapas mentais cognitivos ou a mapas físicos disponíveis em ferramentas externas. Na navegação por integração de trajeto, a pessoa utiliza-se de percepções cinestésicas como meio eficaz de identificar uma rota, seguindo determinado trajeto por meio do tempo de percurso, da distância percorrida e da direção pretendida, utilizando-se de pontos de referência somente de forma esporádica para confirmar ou ajustar seu trajeto.

As cidades oferecem centenas de pontos de referência para navegação, tornandose comum que as pessoas utilizem pontos de referência para tomar decisões de confirmação ou de mudanças de direção até atingirem o destino. Já na navegação em locais sem pontos de referência diretos, como o mar, um deserto ou uma floresta, faz-se necessário o uso da navegação cinestésica.

\footnotetext{
4 De acordo com Schmidt, Delazari (2010) e Lynch (1960), os mapas mentais, também citados como mapas cognitivos, são esboços cartográficos baseados nas memórias das pessoas. Os mapas mentais não utilizam base cartográfica de precisão ou qualquer outro documento prévio. Quando os mapas mentais são transferidos para o papel, recebem a atribuição de croqui.
} 
Os mapas ou cartas geográficas são formas de registrar as características dos ambientes sem que seja necessário memorizá-los, criando uma representação das pistas necessárias ao wayfinding. A cartografia é o conjunto de ciências que orienta a elaboração dos mapas, permitindo que o conhecimento sobre o ambiente seja registrado em meios mecânicos, como o papel.

Mapas comuns são, predominantemente, representações gráficas, que exigem o uso do sentido da visão para serem utilizados. Quando o usuário alvo tem deficiência visual, a construção dos mapas exige uma abordagem diferente. Desde a década de 1970 existem pesquisas para o desenvolvimento de mapas para pessoas com deficiência visual, mapas estes com características táteis para que as pessoas possam utilizar o sentido háptico.

A ciência relacionada aos mapas táteis é a cartografia tátil, um ramo específico da cartografia que se ocupa da produção de produtos cartográficos que possam ser lidos por pessoas cegas ou com baixa visão (LOCH, 2008, p. 39). A foto 1 mostra o exemplo de um mapa tátil fabricado com materiais poliméricos e acomodado sobre um totem de aço inox.

Foto 1 - Mapa tátil instalado na Estação Santa Cecília - Metrô de São Paulo

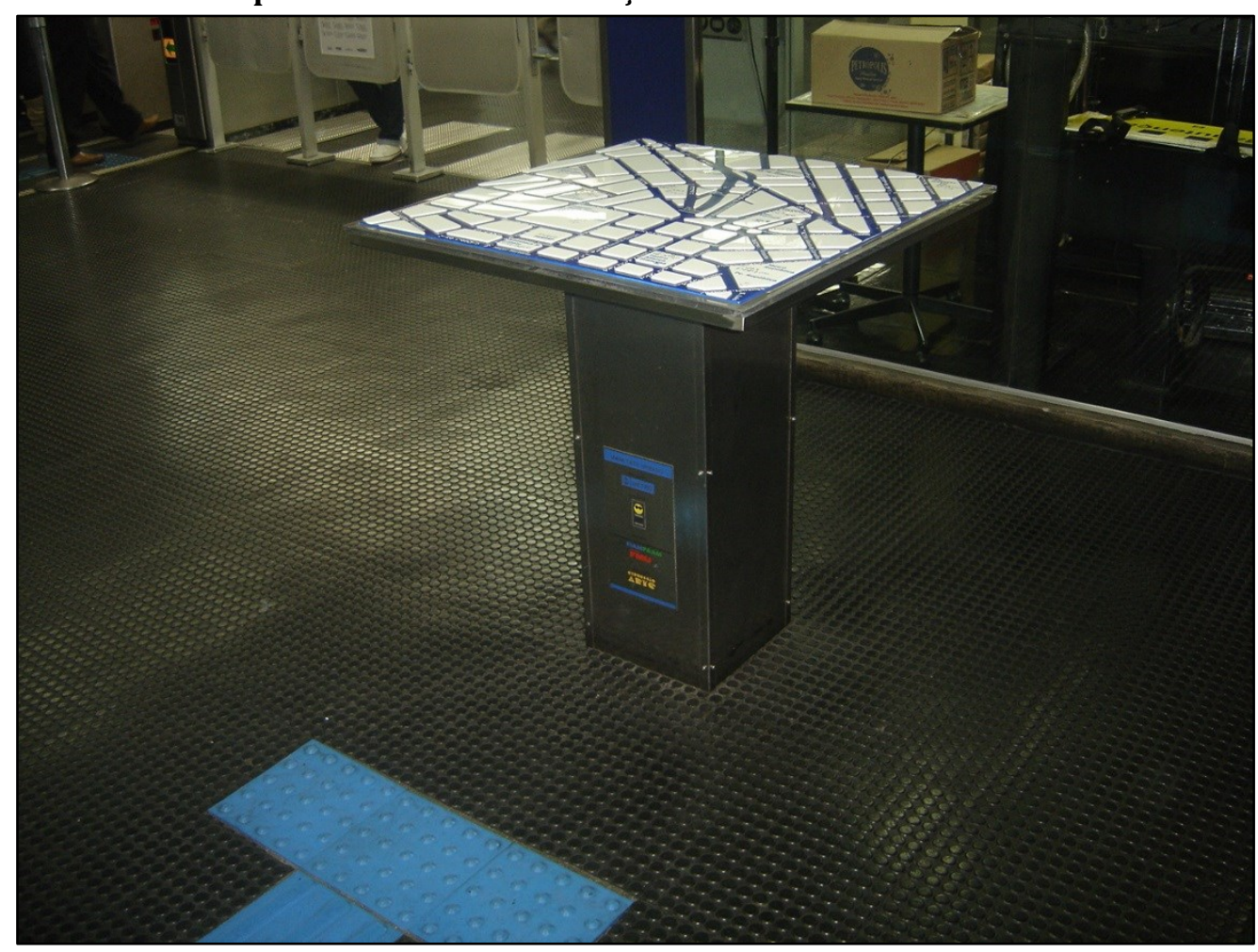

Fonte: do autor (2016) 
Este mapa tátil da foto 1 na página 50 está instalado na Estação Santa Cecília do Metrô de São Paulo para indicar pontos de referência dos arredores da estação. A foto 2 ilustra detalhes deste mapa tátil.

Foto 2 - Detalhes do mapa tátil da Estação Santa Cecília - Metrô de São Paulo

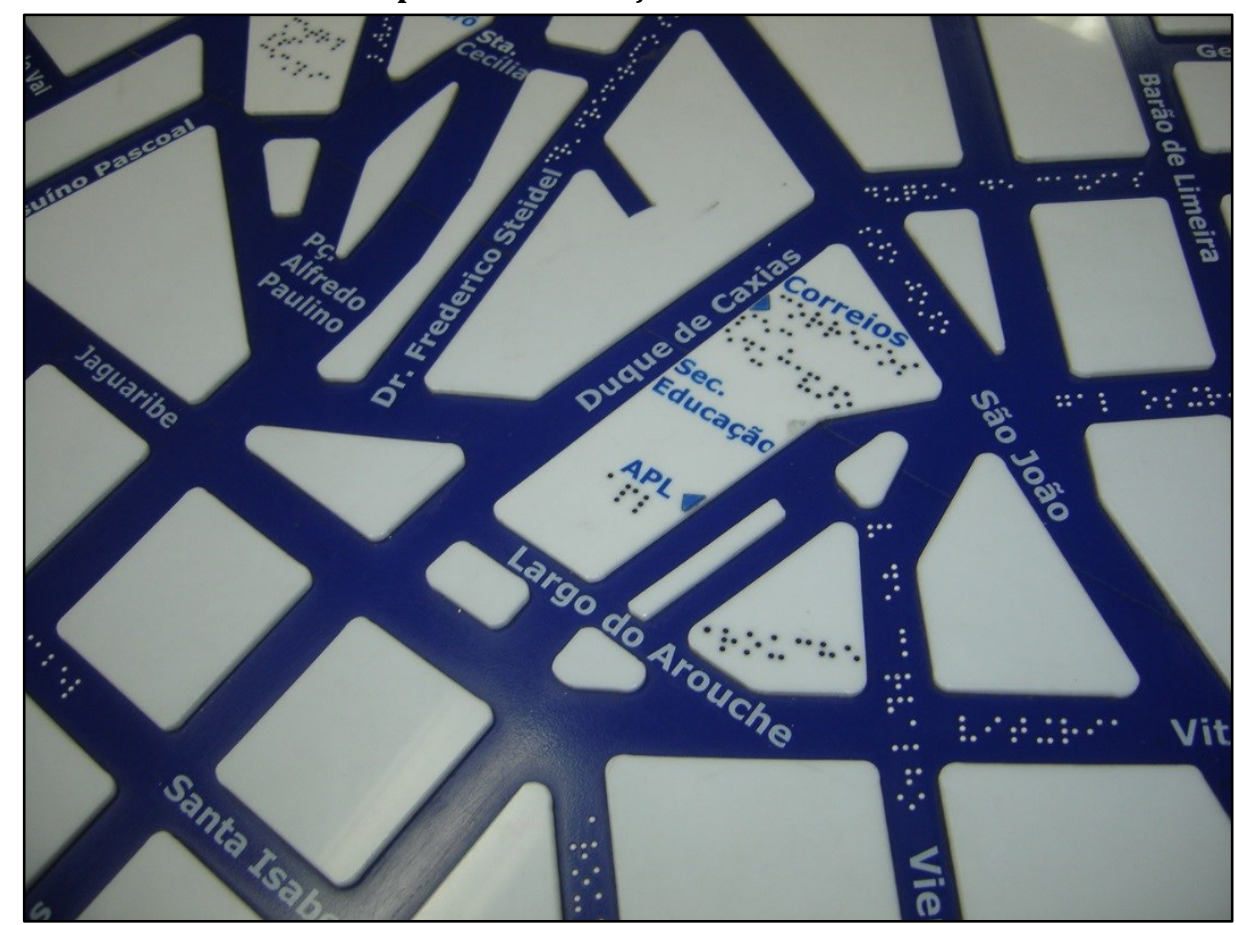

Fonte: do autor (2016)

Os estudos para a elaboração de simbologias na confecção de mapas táteis visam a criação de padrões de design que facilitem a percepção de todas as pessoas com deficiência visual, independentemente do grau de sua deficiência (LOCH, 2008, p. 57), fornecendo medidas, formas, texturas e volumes para a criação de modelos identificáveis pelo tato. A figura 5 (página 52) demonstra um método, proposto por Loch, de padronização de modelos de mapas táteis. 
Figura 5 - Exemplo de padronização de modelos para mapas táteis

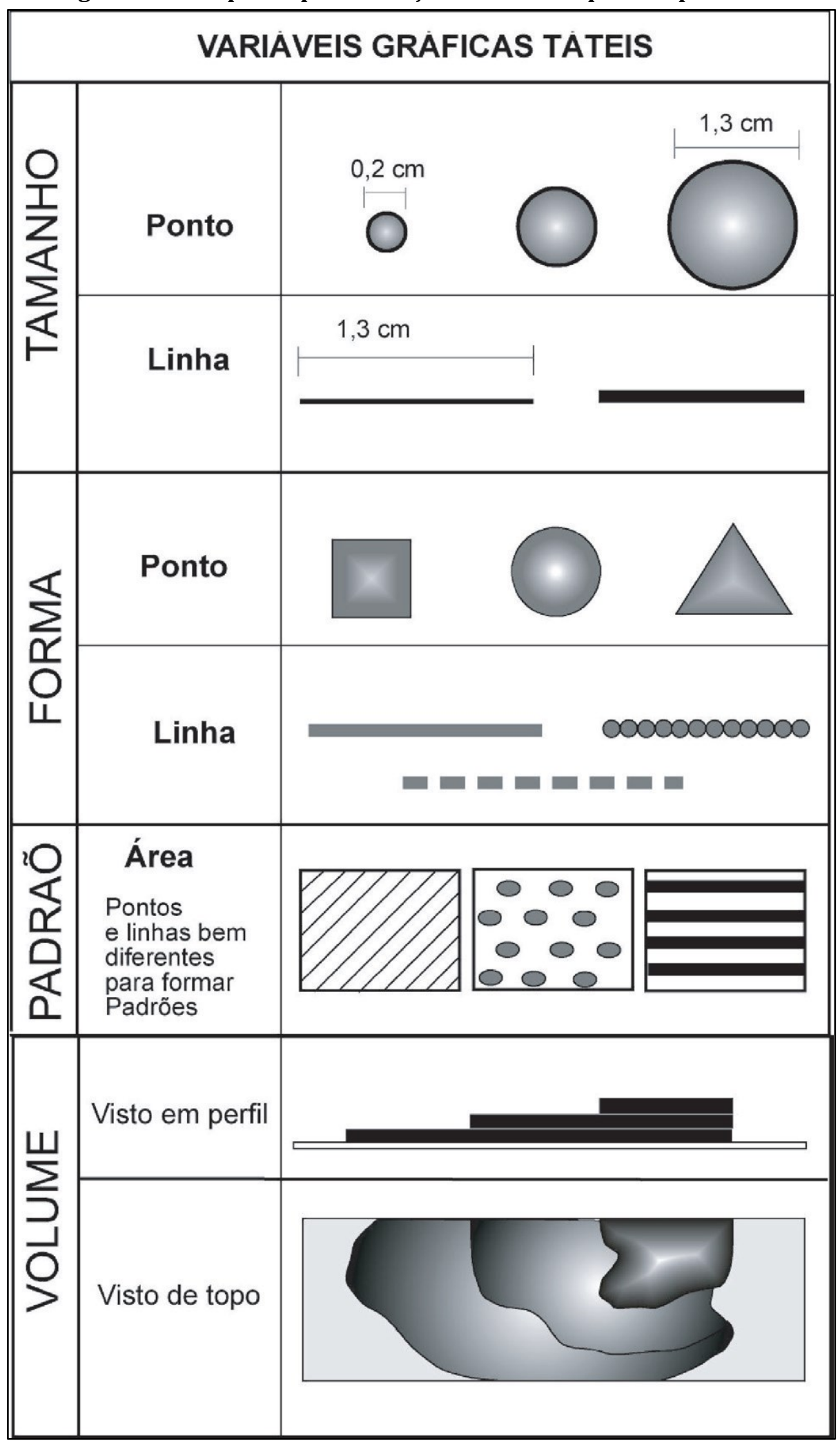

Fonte: Loch (2008, p. 49) 
A utilização de mapas táteis pode diferir na utilização de mapas visuais também em outro domínio: a portabilidade. Enquanto mapas visuais podem ser desenhados em papéis, as pesquisas de materiais para cartografia tátil utilizam predominantemente materiais rígidos, de difícil portabilidade, ou materiais maleáveis, mas que podem ser danificados muito facilmente se transportados ou se forem dobrados (NOGUEIRA, 2009, p. 21). Além disso, a necessidade de se fazer uso da ponta dos dedos para reconhecer os mapas táteis exige que o usuário segure o mapa com uma mão e utilize a outra para lê-lo. Esta forma de uso não é compatível com a mobilidade, pois as pessoas com deficiência visual precisam usar ao menos uma mão para segurar a bengala longa ou o cão-guia. Portanto, mapas táteis transportáveis podem ser difíceis de utilizar quando a pessoa está caminhando, e para serem utilizados pela pessoa parada, exigem que a pessoa memorize o caminho antes de segui-lo. Estas dificuldades devem ser consideradas ao se planejar rotas orientadas por registros em mapas táteis

Para facilitar a memorização e a criação de mapas mentais, Apelt, Crawford e Hogan (2007, p. 13) citam que a sinalização deve ser projetada de forma a universalizar o reconhecimento desta sinalização, por meio da padronização de sinais visuais e hápticos, como a adoção de identificação padrão para os locais, cuidados com a coerência na elaboração dos ambientes (por exemplo, seguir uma numeração sequencial para casas nas ruas e em salas de ambientes internos), criando-se um protocolo de comunicação familiar sobre o ambiente, facilitando seu uso, considerando-se a existência de comunicação adequada para atender a todas as pessoas, com deficiência ou não.

\subsubsection{MOBILIDADE COM BENGALA LONGA}

De acordo com Cerqueira (2011) existem, em diversos registros históricos da antiguidade, citações de pessoas utilizando-se de bengalas, bastões, cajados e outros instrumentos semelhantes como extensões do corpo, para ações defensivas e ofensivas, como instrumento de controle de rebanhos e também como instrumento simbólico de autoridade e realeza, quando a pessoa porta o bastão sob a forma de cedro. 
A ação de pessoas com deficiência visual caminhando pelos ambientes pode tomar proporções quase sobrenaturais a pessoas que desconhecem a capacidade de adaptação do ser humano. Levy $(2015$, p. 68) cita que, no final do século XIX, a crença popular era que a as pessoas com deficiência visual conseguiam caminhar com suas bengalas sem que outras pessoas as guiassem devido a alguma proteção de entidades divinas. Ainda que se desconsiderem as citações sobre auxílios divinos no ato de caminhar de pessoas com deficiência visual naquela época, se faz importante notar que já ocorria o uso de bengalas por pessoas com deficiência visual, embora sem um método padronizado de utilização.

0 uso da bengala moderna para cegos, a chamada bengala longa, tem início na primeira metade do século XX. Sua história está associada às duas grandes guerras mundiais, de 1914 a 1918 e 1939 a 1945, quando os soldados norte-americanos retornavam aos Estados Unidos da América, muitos deles com ferimentos de guerra que lhes tiraram a capacidade de visão. Surgiram então, nos serviços de saúde norte-americanos, as primeiras instituições empenhadas na reabilitação dos veteranos de guerra, tornando-se os pioneiros no processo de pesquisar formas de locomoção independente de pessoas com deficiência visual.

De acordo com Turtle e Turtle (2002), em 1944 o professor doutor Richard Edwin Hoover, sargento médico do exército norte-americano, foi designado para o Hospital Militar de Valley Forge para tratar de veteranos de guerra com cegueira. Durante seu serviço militar, Hoover desenvolveu uma bengala para o uso de seus pacientes, buscando substituir a bengala curta, amplamente utilizada na época, nomeando esta nova ferramenta como bengala "leve" longa. Também desenvolveu a técnica de movimentar a bengala, utilizando a ajuda de voluntários convidados entre seus pacientes e corpo médico, técnica esta que consiste em tocar com a ponta da bengala os pontos no solo à frente do corpo. Surgiu assim a bengala longa. 
A foto 3 mostra uma pessoa com deficiência visual rastreando a frente de seu caminho com a bengala longa.

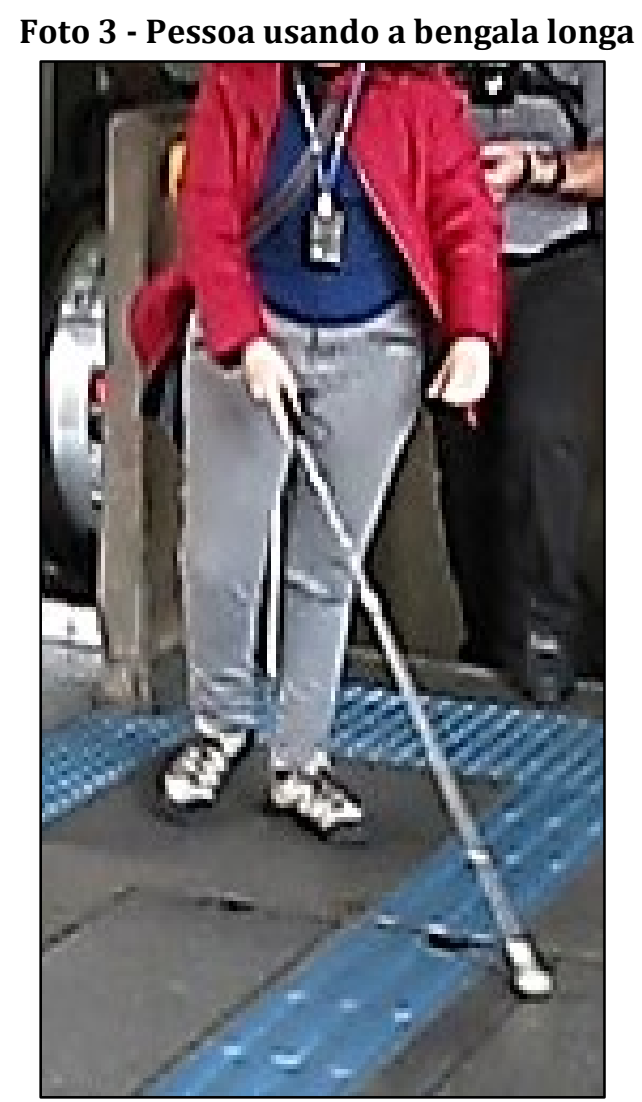

Fonte: do autor (2016)

A bengala longa e suas técnicas de utilização são hoje a principal tecnologia assistiva de uso individual, tornando possível o deslocamento de pessoas com deficiência visual. Construída com diversos materiais em diversas medidas, a bengala longa, ou simplesmente bengala, tem como função principal incrementar a segurança no ato de caminhar ao ampliar o sentido do tato, transmitindo para a mão da pessoa com deficiência visual as informações hápticas sobre a existência de obstáculos, sensações de textura e desníveis do piso (FELIPPE, 2001, p. 3; SANTOS e CASTRO, 2013).

Mariani (2016, p. 59) afirma que as pessoas com deficiência visual usam a bengala para sentirem os desníveis no solo, constituindo-se de um dos elementos mais antigos e usuais para a exploração do espaço por tornar possível a obtenção de informações táteis de forma antecipada acerca de obstáculos no caminho. Cerqueira (2011) cita que a bengala longa é um instrumento básico de locomoção 
que proporciona segurança, autoconfiança e independência às pessoas com deficiência visual, demonstrando uma perspectiva pragmática do objeto.

Já Mansini (1992, p. 31) tem uma perspectiva abstrata sobre a bengala longa, ao citar que esta não é um objeto que está em primeiro plano na percepção da pessoa com deficiência visual, é um objeto que age como um apêndice, uma extensão da síntese corporal, criando assim uma maneira peculiar de percepção do mundo.

De acordo com Paranhos (2008, p. 29), a importância da bengala para as pessoas com deficiência visual pode ser aplicada sob dois pontos de vista: na prática, por proporcionar o ritmo presente no som da ponta batendo no solo e da proteção quando o som e o movimento mudam ao encontrar um obstáculo, e do ponto de vista psicológico, por ser o signo da liberdade, segurança, amparo e reconhecimento dos videntes sobre sua condição física. Este último signo de reconhecimento também é citado por Santos e Castro $(2013$, p. 6), ao afirmarem que a bengala longa simboliza um identificador para o conceito coletivo, um signo tão poderoso que as necessidades de uma pessoa com deficiência visual podem até mesmo serem ignoradas por outras pessoas ao redor caso esta não esteja usando a bengala.

O conceito coletivo da necessidade de atenção pela presença de pessoa com deficiência visual justificaria sozinho o uso da bengala como signo por todas as pessoas com deficiência visual. No entanto 0'Sullivan et al. (2001, p. 92) afirmam que os signos, quando percebidos de forma simplificada e generalizada, podem representar um conjunto de juízos e predisposições que remetam a uma falsa percepção de valores sociais. Assim, para uma pessoa que tenha perdido recentemente a visão, o signo que a bengala representa pode gerar a recusa ou a dificuldade de uso, pois o signo da bengala pode representar a aceitação da situação de perda de visão, a vivência do luto, exigindo-se muitas vezes o trabalho de um profissional em psicologia, na busca pelo aumento de sua autoestima enquanto recebe o treinamento de orientação e mobilidade (SANTOS e CASTRO, 2013, p. 6). Pelos mesmos motivos, outros objetos relacionados à perda da visão podem ser alvo de recusa ou resistência ao uso. É neste ponto que se mostra a importância da aplicação do conceito de design universal, pois, ao projetarem-se 
equipamentos comuns, que todos possam utilizar, ou então se readequando objetos de uso cotidiano para o uso de todos, evita-se o mesmo estigma inicial representado pela a bengala longa, reduzindo a probabilidade de resistência à utilização.

A utilização combinada dos diversos tipos de tecnologias assistivas pode incrementar a precisão da percepção do ambiente. Ao se combinar a informação tátil oferecida pela bengala com a descrição por voz, a pessoa com deficiência visual pode utilizar informações sobre o ambiente e sobre o caminho a ser seguido, enquanto realiza um rastreamento com a bengala para perceber diferenças de piso ou obstáculos não previstos pela voz. Ao aliar-se ainda o direcionamento por meio de piso tátil, a pessoa com deficiência visual obtém informações bem completas sobre o ambiente e sobre o caminho que está seguindo, enquanto faz uso do piso tátil para evitar riscos ambientais.

\subsubsection{A SINALIZAÇÃO TÁTIL DE PISO (PISO TÁTIL)}

Uma das formas mais comuns de utilizar a bengala longa é seguindo uma linhaguia. De acordo com David, Antunes e Gurgel (2009, p. 87), o alcance da bengala, apesar de restrito e limitado, pode ser melhorado com o uso de linha guia para orientação, incrementando a segurança ao fornecer um trajeto distante de pontos de risco ou perigo.

De acordo com a Associação Brasileira de Normas Técnicas (ABNT), linha guia é qualquer elemento natural ou edificado que possa ser utilizado como referência de orientação direcional por todas as pessoas, especialmente as pessoas com deficiência visual (ABNT, 2015, p. 5). Então, diversas referências nos ambientes, tanto abertos como cobertos, podem ser utilizados por pessoas com deficiência visual como orientação. Os mais comuns podem ser paredes, muros e muretas, mas quaisquer outras referências no ambiente podem ser utilizadas como linha guia. Não são consideradas linhas guias os locais que podem incorrer em risco ou perigo às pessoas com deficiência visual como, por exemplo, o meio-fio das calçadas, pois nestes locais podem estar posicionados diversos obstáculos como postes, placas, telefones públicos, lixeiras, mobiliário, além de o local ser muito próximo a veículos em movimento (IPUF, 2015, p. 14; ABNT, 2016, p. 25). 
A sinalização tátil de piso, conhecido como piso tátil é, como nome sugere, uma sinalização para ser incorporada ao piso ou calçamento urbano, formando assim uma linha guia planejada. No Brasil, suas especificações são definidas pelas normas NBR-9050:2015 (ABNT, 2015, p. 47-81) e NBR-16537:2016 (ABNT, 2016), caracterizando-se como um tipo de piso instalado no calçamento que o diferencie do piso adjacente em cor e textura. É destinado para servir de orientação principalmente às pessoas com deficiência visual ou baixa visão. Para atingir o objetivo de guiar e de alertar, existem dois tipos de piso tátil: o piso tátil de alerta e o piso tátil direcional (ABNT, 2015, p. 5; ABNT, 2016, p. 3).

O piso tátil de alerta é utilizado para sinalizar situações de risco, para sinalizar a existência de equipamentos e mobiliários urbanos e para informar mudanças de direção. Como exemplo de situações de risco, pode-se citar a existência de desníveis e a possibilidade de colisão com placas, postes e orelhões de telefones públicos. Como exemplos de sinalização, pode-se citar a existência de equipamentos para uso das pessoas, como elevadores, aparelhos de autoatendimento e serviços. 0 piso tátil também é usado para informar mudanças de direção ou opções de percurso, indicar locais de travessia de pedestres, o início e o término de rampas e escadas, sinalizar a existência de seus patamares, além de servir para indicar áreas limítrofes de plataformas elevadas, como as utilizadas em estações de trens e metrôs (ABNT, 2015, p. 48; ABNT, 2016, p. 5-7). Todas essas sinalizações, informações e indicações com o mesmo tipo de piso tátil de alerta, sem oferecer detalhes sobre o tipo de alerta, sinalização ou indicação (foto 4).

Foto 4 - Exemplo de piso tátil de alerta

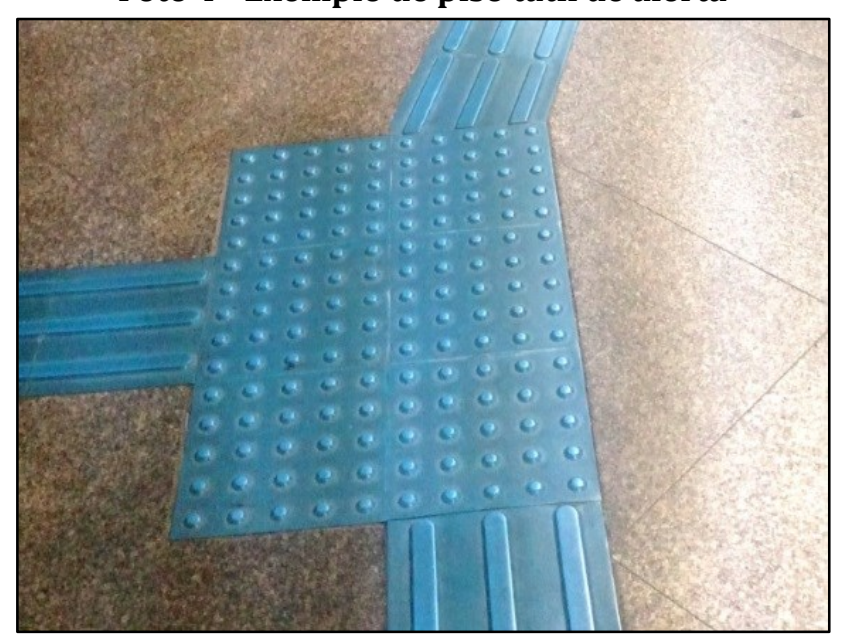

Fonte: do autor (2016) 
O outro tipo de sinalização é a promovida pelo piso tátil direcional. Este tipo de sinalização é utilizado em ambientes internos ou ao ar livre, no sentido de deslocamento das pessoas, quando não existe uma linha guia ou quando esta é descontínua (ABNT, 2015, p. 49; ABNT, 2016, p. 7-9) e em espaços amplos (IPUF, 2015, p. 12).

O piso tátil direcional fornece à pessoa com deficiência visual a indicação que está seguindo por um caminho sem obstáculos. No entanto, caso a pessoa não tenha familiaridade com o ambiente, esta informação é insuficiente, pois não há formas de a pessoa identificar os destinos que o piso direcional oferece (foto 5).

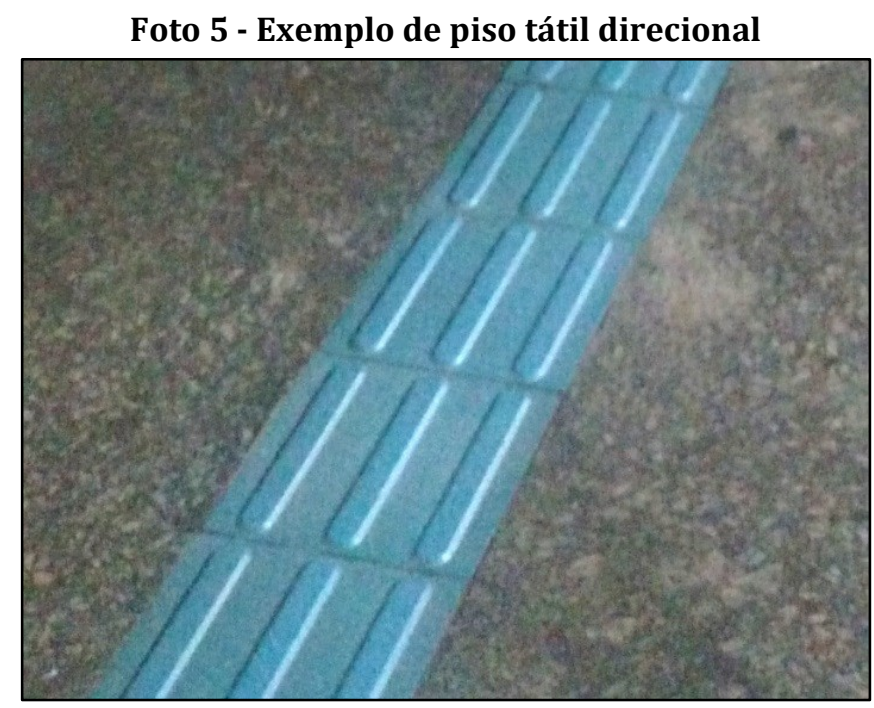

Fonte: do autor (2016)

Apesar de ser uma solução simples, o piso tátil facilita o deslocamento das pessoas com deficiência visual, ao fornecer um caminho a ser seguido e alertar sobre a existência de equipamentos e serviços ao longo do trajeto. No entanto, como é uma solução simples, o piso tátil não fornece detalhes sobre o caminho ou sobre os alertas os quais ele está se referindo. Assim, o piso tátil demonstra ser uma importante ferramenta para a autonomia na mobilidade de pessoas com deficiência visual, mas o aproveitamento de suas funcionalidades pode ser potencializado, quando utilizado em conjunto com tecnologias assistivas que complementem suas sinalizações por meio do fornecimento de informações mais abrangentes sobre o trajeto do piso tátil direcional e sobre os avisos do piso tátil de alerta. 


\subsubsection{O CÃO-GUIA}

Sendo um importante recurso de acessibilidade para a orientação e mobilidade, o cão-guia talvez seja também o mais controverso, não por sua importância, mas pelo que representa à sociedade. 0 cão-guia tem sua eficiência comprovada diariamente, mas enfrenta resistência por conta do desconhecimento de outras pessoas, devido a diversos motivos, desde o medo pessoal de animais até a resistência em dividir com eles os espaços supostamente inadequados, como locais de comércio de alimentos.

Existem poucas regulamentações brasileiras quando o assunto é usar um cão-guia. A lei federal 11.126 (BRASIL, 2005) garante o direito do ingresso e permanência de pessoa com deficiência visual acompanhada de seu cão-guia, sem uso de focinheira ${ }^{5}$, em todos os meios de transporte e em estabelecimentos de uso público e privados de uso coletivo. Além desta lei, não há outras citações e parametrizações sobre cães-guia no Brasil.

Fukuhara et al. (2014, p. 3) citam que o cão-guia faz parte de um esforço de acessibilidade chamado de treinamento de cães de serviço. Para uma pessoa com deficiência física o cão de serviço pode pegar objetos, acionar interruptores e, o mais importante, buscar ajuda em caso de quedas ou emergências de saúde. Para uma pessoa com deficiência auditiva, o cão de serviço pode alertar sobre riscos fora de seu campo de visão. Para as pessoas com deficiência visual, o cão-guia serve para auxiliar na mobilidade, protegendo a pessoa contra possibilidade de colisões ou quedas.

O uso dos cães de serviço também promove o bem-estar psicológico das pessoas com deficiência. Valentine, Kiddoo e Lafleur (2008) citam o aumento da confiança, da tolerância e da independência após a pessoa adquirir o cão de serviço, com resultados positivos de aumento da autoestima.

\footnotetext{
${ }^{5}$ Focinheira, trela ou açaimo é uma proteção para ser colocada na cabeça de animais, como cães e gatos, de forma a impedir que este utilize a boca para morder, mas permita a ingestão de alimentos pastosos e água (PRADO, SILVA, et al., 2011; MOURO, L.VILELA e NIZA, 2009).
} 
De acordo com Brito (2009), o treinamento de cães-guia ainda é raro no Brasil, e a maioria dos cães em uso no país é doada pelo Instituto de Integração Social e de Promoção da Cidadania, com sede em Brasília, que normalmente adquire os animais dos Estados Unidos da América e do Canadá, pois os Estados Unidos da América é o país pioneiro em treinamento em massa de cães-guia, devido ao esforço de diversas instituições para melhorar a vida de veteranos que retornaram cegos das batalhas das duas grandes guerras, à semelhança do desenvolvimento da bengala longa.

O uso do cão-guia exige também treinamento e mudança de costumes dos candidatos com deficiência visual. Um exemplo reside no uso da bengala longa, que é maciça entre pessoas com deficiência visual: para Casals (2007, p. 34), a utilização do cão-guia em conjunto com a bengala longa não é somente difícil, é uma situação completamente incompatível. No entanto, Casals complementa que o aprendizado do uso do cão-guia exige que a pessoa com deficiência visual já tenha experiência com técnicas de orientação e mobilidade por meio de tecnologias assistivas. Esta afirmação concorda com Ramos (2009, p. 31), que estabelece como fundamental o conhecimento prévio das técnicas de orientação e mobilidade pelo candidato a receber um cão-guia, pois a função principal do cão-guia não é prover orientação, é proteger a integridade física da pessoa por meio da identificação de situações de riscos ambientais, como obstáculos no solo ou na altura da cabeça. Assim, percebe-se que o cão-guia não faz uso de habilidades de wayfinding, exceto se o cão for ensinado a seguir uma rota previamente conhecida. Além disso, a pessoa com deficiência visual precisa das habilidades de orientação e mobilidade para não se tornar totalmente dependente do cão para executar suas tarefas diárias, pois o cão pode adoecer ou ser perdido. 


\subsection{PROCESSOS COGNITIVOS E SUAS IMPLICAÇÕES PARA O DESIGN}

As tarefas que as pessoas precisam realizar no dia-a-dia demandam de decisões. As pessoas tomam decisões a todo o momento, tanto conscientemente, ao escolher uma ação ao invés de outra, como inconscientemente, de forma quase automatizada, com base na combinação da identificação das características formais presentes nos objetos e nos instintos preexistentes em cada indivíduo (PENNA, 1987, p. 40). Os processos necessários para que as pessoas tomem decisões e, consequentemente, possam realizar suas tarefas, são os processos cognitivos, que são a combinação de diversos fatores psicológicos, físicos e sensoriais para permitir que a pessoa tome decisões.

Cognição é a capacidade da pessoa em compreender as informações percebidas pelos sentidos, utilizando o processamento mental, e quando a cognição está relacionada à percepção do mundo ao nosso redor, diversos sentidos podem estar envolvidos. Estes sentidos são muito mais do que visão, audição, tato, olfato e paladar, mas se estendem para o sistema háptico que, combinado com a memória e o sentido vestibular, proporciona a cinestesia.

De acordo com Schiffman (2005, p. 313) o sistema háptico ou tato ativo é o conjunto de sensações responsável pela percepção das propriedades geométricas, como medidas, peso, consistência, formatos, proporções e movimento dos objetos. Já o sentido vestibular é uma função complexa, conforme Ganança et al. (1999), responsável pelo equilíbrio corporal, composto pela sensação de deslocamento percebida pelo labirinto, pela posição no ambiente percebido com os olhos, pela sensação das superfícies em contato com a pele e pela a informação da posição dos músculos, das articulações, assim como dos movimentos corporais que estas partes produzem. Quanto à cinestesia, também conhecida por propriocepção, é definida por Schiffman (2005) como o sentido da percepção de movimento, equilíbrio, peso, força e resistência dos músculos e posição de cada parte do corpo do indivíduo, identificado por meio de uma combinação de informações táteis, posição das fibras musculares e do sistema vestibular, localizado no ouvido interno. 
De acordo com Rogers, Sharp e Preece (2013, p. 71) as pessoas criam uma ascendência de importância dos sentidos: usam primeiro a percepção da visão, que é seguida pela audição e pelo tato, e a combinação das dos sinais destes sentidos criam ligações sinápticas para formar memórias. Quando o sentido da visão é insuficiente ou ausente, o corpo precisa compensar com os outros sentidos para a orientação e a mobilidade. De acordo com Ganança et al. (1999), as informações provindas dos sentidos vão ser analisadas em áreas específicas do sistema nervoso central, providenciando correções rápidas do posicionamento do corpo, garantindo o equilíbrio, e se as informações forem incoerentes ou conflitantes a pessoa sofre tontura e outros sintomas associados.

Os ambientes, caminhos, ruas, edifícios, áreas, etc. são dinâmicos, sempre mudam de estado ou posição ao longo do tempo. As pessoas videntes tendem a imaginar os ambientes como representações estáticas, mas não são necessariamente assim, as pequenas diferenças que ocorrem com o tempo são compensadas inconscientemente pela visão. Para Dischinger (2000, p. 232), os elementos dinâmicos e estáticos dos ambientes interagem para modificar a percepção espacial, e por isso essa percepção não pode ser reduzida a simples "imagens congeladas" do ambiente, pois o reconhecimento espacial é a unificação das informações fornecidas pelos elementos permanentes com as diferenças temporais, os elementos móveis e até mesmo elementos sociais.

Para Machado et al. (2003) e Mariani (2016, p. 53), as pessoas também utilizam uma percepção sensorial chamada "sombra sonora". É, de fato, o eco sonoro que grandes obstáculos produzem ao refletirem os sons ambientes, ecos estes percebidos pelos ouvidos sobre diferenças de tempo entre o som original e seu eco. Pouco utilizado por pessoas videntes, esta percepção tende a se tornar mais importante para pessoas com deficiência visual, que se utilizam muito os ouvidos para a percepção ambiental.

As habilidades provindas dos processos cognitivos para o deslocamento da pessoa através dos espaços também envolvem a associação correlativa dos elementos pertencente ao ambiente. De acordo com Carlin e Ely (2005, p. 307) a orientação espacial depende da habilidade de uma pessoa em organizar mentalmente as 
características espaciais do arranjo físico do ambiente, situando-se dentro desta representação, criando assim um mapa cognitivo mental sobre o ambiente. Este mapa mental demanda, além da percepção do estado atual dos elementos, de experiências e sensações anteriores, por meio das affordances do ambiente.

De acordo com Gibson (1986, p. 127), as affordances dos ambientes referem-se ao que é oferecido, interativamente, ao indivíduo que os utilizam, e implicam na complementariedade entre o indivíduo e o ambiente. 0 autor cita como affordances o meio, como por exemplo, o ar, as substâncias como a água e os sólidos, as superfícies, os objetos e até mesmo os outros seres vivos no ambiente, sendo estas últimas fontes das mais ricas e elaboradas affordances que podem fazer parte do ambiente.

No domínio dos objetos, o conceito de affordances sobrepuja as características explicitas destes, envolvendo tanto as funcionalidades que o designer pensou como outras possíveis funcionalidades que o usuário sente, descobre ou percebe para os objetos (BROCH, 2010, p. 16; NORMAN, 2006, p. 33).

As affordances podem se tornar ainda mais poderosas para pessoas com deficiência visual. Para Mariani (2016, p. 55) as affordances são o que oferecem de mais importante no processo cognitivo das pessoas com deficiência visual, pois suas experiências prévias, expectativas e desejos sobre os locais onde se locomovem condicionam suas expectativas, podendo modificar suas habilidades, competências motoras e sensação de segurança. Esta afirmação pode ser notada em pessoas com deficiência visual adquirida após a idade adulta, quando caminham em ambientes os quais possuem memória visual que podem interferir na percepção sobre o estado atual do ambiente.

No entanto, a memória visual pode se perder ao longo do tempo. O Dr. John Martin Hull, escritor australiano e deficiente visual com cegueira adquirida, foi perdendo gradativamente sua visão desde os 13 anos, quando adquiriu catarata, tornando-se totalmente cego aos 48 anos. Sua história com a cegueira, contada no livro Touching the rock: an experience of blindness (HULL, 1992), narra o decréscimo da memória visual com o passar dos anos, demonstrando que nem sempre pessoas com deficiência visual adquirida mantêm lembranças de imagens. 
0 médico neurologista Oliver Sacks faz uma análise dos relatos de Hull (SACKS, 2010, p. 179-182), impressionando-se com a mudança gradativa de sua percepção do mundo: dois anos depois de se tornar totalmente cego, Hull parecia tão desprovido de imagens e de memória visual quanto um cego congênito. A formação de sensações sobre o mundo ao seu redor já estava totalmente modificado, não só as imagens desapareceram da mente, mas também conceitos predominantemente visuais, como "aqui", "alí" e "lá" não faziam mais sentido. Hull afirmou que passou a enxergar o mundo com o corpo, não com imagens.

O pressuposto de que pessoas cegas vivem em um mundo de trevas é um conceito impreciso. Tomando o termo "trevas" ao significado de escuridão visual, algumas pessoas com cegueira recentemente adquirida, que se lembram da visão, citam que a percepção que o cérebro sente pode ser o escuro, mas também pode variar até o totalmente claro. Existem casos de pessoas que tiveram dificuldades para dormir por longos períodos de tempo após tornarem-se cegas, pois seu sentido da visão mostrava uma claridade constante ao invés da escuridão. Quando atribuímos o termo "trevas" à incapacidade de reconhecer o ambiente, depoimentos como os de John Hull demonstram o oposto.

Estas premissas devem ser observadas pelo designer durante o processo de desenvolvimento de interfaces para pessoas com deficiência visual. Para Mburu (2013, p. 8), o conceito de interface é mais amplo do que simples projetos de controle e resposta para máquinas e computadores, pois envolve todo o conjunto necessário para desenvolver a tarefa, desde os processos cognitivos do usuário até o conhecimento das características da máquina. Assim, o designer deve realizar seu projeto com base em toda a cadeia relacionada à tarefa a ser executada, desde a memória, percepção, inteligência e capacidade motoras relacionadas às ações consciente e inconsciente das pessoas até as capacidades de processamento e memória das máquinas. A figura 6, na página 66, ilustra este modelo de estrutura para a elaboração da interface. 
Figura 6 - Modelo de interface humano-máquina

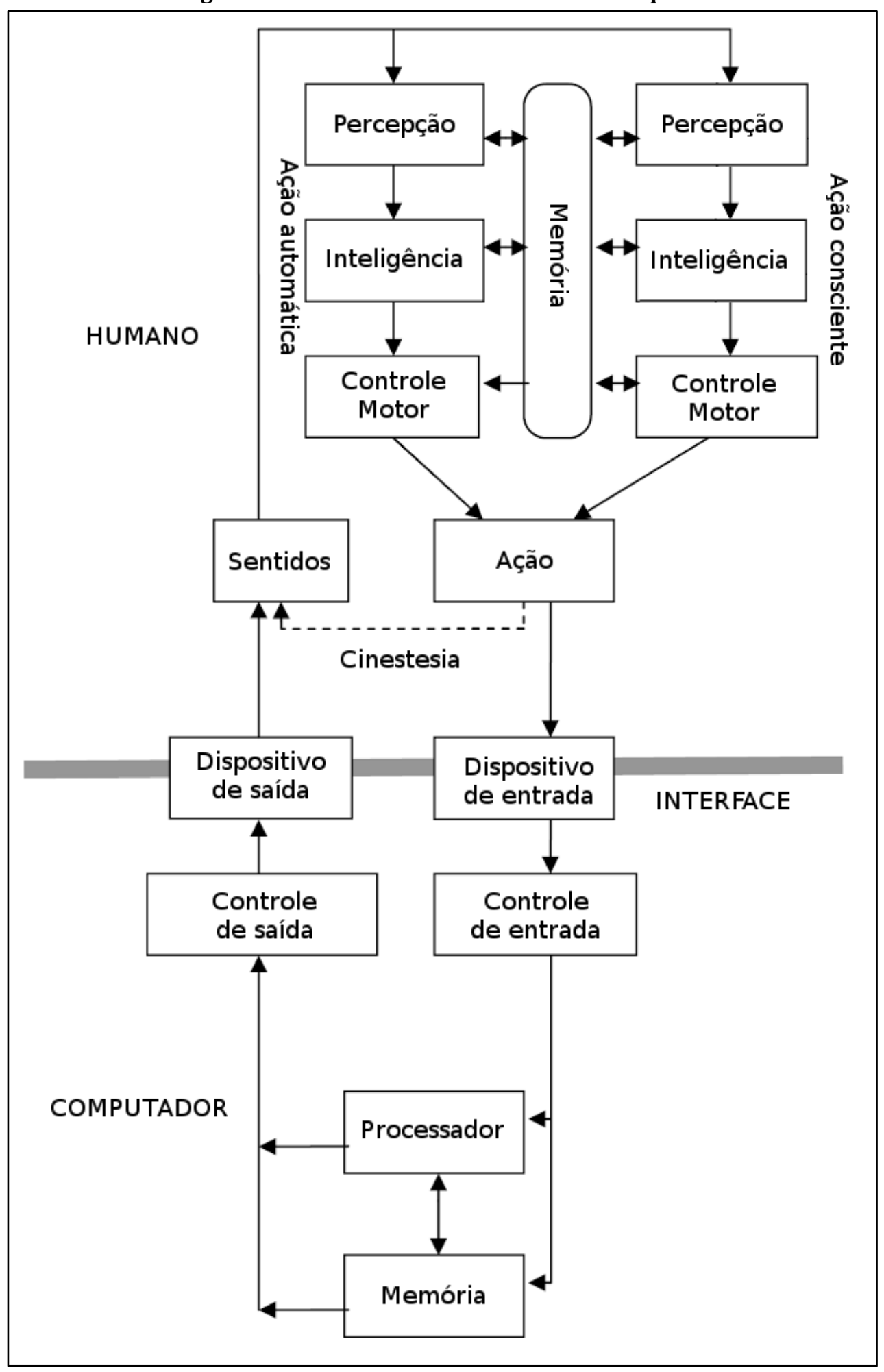

Fonte: o autor, com base em Mburu (2013, p. 8) 
De acordo com Hatwell (2003, p. 67-68), a cegueira não modifica os limites e a acuidade sensorial, mas redireciona a atenção para signos não visuais, por meio do aperfeiçoamento dos procedimentos exploratórios do tato e da audição, não por meio da potencialização destes sentidos, mas pelo aprendizado, acostumando-se com signos que não fazem parte do domínio cognitivo das pessoas videntes.

A percepção do mundo pelas pessoas com deficiência visual não é inferior à percepção das pessoas videntes, é só diferente. Por este motivo, durante o desenvolvimento de interfaces, o designer precisa considerar as capacidades cognitivas de seu usuário foco, por meio do estudo das peculiaridades dos usuários com a participação dos próprios usuários (AMARANTE e LIMA, 2009). Este processo é ainda mais necessário quando a pessoas tem deficiência visual, pois a suposição de que basta suprimir a visão de um voluntário vidente para compreender a deficiência visual é ingênua, os processos cognitivos das pessoas com deficiência visual são distintas das pessoas videntes, estendendo-se muito além da simples falta da capacidade visual.

Carvalho (1994, p. 39) afirma que é muito significativa a quantidade de interfaces projetadas por profissionais com bom conhecimento técnico sobre aspectos computacionais, mas que desconsideram que os aspectos humanos possuem importância e relevância para o bom funcionamento do sistema, sendo comum o desenvolvimento de interfaces que não levam em conta os processos envolvidos no pensamento dos usuários, considerando, muitas vezes, que os modelos mentais dos usuários são semelhantes aos seus.

Para Kulpa (2009, p. 23), muitos designers concentram esforços no desenvolvimento de sistemas com grande qualidade técnica na esfera interna do produto, mas desprezam a importância da elaboração de uma interface satisfatória para ao usuário, que muitas vezes não conhece os pormenores do funcionamento do sistema, tendo como única referência à interface a ele disponibilizada.

Kulpa (2009, p. 22) também cita que a lógica da compreensão dos elementos da interface é atingida quando o usuário consegue manipular, de forma axiomática e sem a necessidade de conhecimentos sobre o funcionamento interno da máquina, os conceitos representados pelos elementos da interface, ao relacionar o 
significado percebido pelo usuário ao resultado pretendido pelo designer, pois problemas axiomáticos na interface podem causar um efeito inesperado: segundo Norman (2006, p. 58), quando os usuários cometem os erros ao interagir com interfaces, com frequência se consideram culpadas pelo erro, presumindo "estupidez" ou "falta de jeito", sentimento este acentuado se a tarefa parece simples ou trivial, pois raramente o usuário percebe falhas na interface do equipamento.

$\mathrm{Na}$ busca pela forma correta dos usuários manejarem as interfaces, os designers precisam estimular corretamente os processos cognitivos. Dentre as ferramentas de estímulo, Rocha, Zanetti (2012, p. 66) e Norman (2006, p. 33) trazem do domínio dos objetos reais para o domínio dos objetos virtuais o conceito de affordance, incorporando-o nas interfaces digitais. Assim, pode ocorrer de o usuário descobrir affordances que o designer de determinado objeto sequer pensou existir.

A ausência de cuidados com as affordances pode constituir problemas quando os designers tentam representar situações e objetos reais por meio de objetos virtuais nos elementos das interfaces digitais. A interação do usuário com elementos visuais, sonoros e hápticos das interfaces digitais precisa ser facilitada pelo estudo das affordances que o designer deseja por meio da correta expressão da ação que a metacomunicação que o conteúdo pode representar (LEITE, 1998, p. 99). Este cuidado com a interface pode ser dificultado quando o usuário tem deficiência visual, pois todas as representações de situações e objetos precisam ser feitas sem utilizar imagens.

Os processos cognitivos são empregados nas tomadas de decisão. Rogers, Sharp e Preece (2013) elencam as especificidades envolvidas no processo cognitivo, demonstrando que cada especificidade é relacionada a um ou mais dos sentidos humanos. 0 estudo destas especificidades pode auxiliar no planejamento do design de soluções inclusivas. São os processos da atenção, percepção, memória, aprendizado, linguagem e tomada de decisão. 


\subsubsection{PROCESSO DA ATENÇÃO}

- COM BASE EM ROGERS, SHARP E PREECE (2013, P. 67).

É o processo no qual a pessoa seleciona uma ação ou situação dentre uma variedade de outras possíveis, as pessoas tomam providências para manter a atenção em situações desejadas. Rogers, Sharp e Preece citam que a atenção demanda dos sentidos da visão e da audição. A atenção permite que as pessoas criem prioridades e definam metas com base nas informações relevantes disponíveis nos ambientes nas interfaces e nas tarefas a serem executadas. 0 quadro 1 ilustra os subsídios necessários no design para o processo da atenção, com base nos sentidos das pessoas e em suas ações relacionadas a estes sentidos.

Quadro 1 - Processo da atenção

\begin{tabular}{lll}
\hline Sentidos & \multicolumn{1}{c}{ Ações envolvidas } & Subsídios para o design \\
\hline Visão, & Interrupção de tarefas, & Organizar prioridades, destacar a \\
audição e & seleção de opções, & informação importante e \\
tato. & focalização e \\
& estabelecimento de \\
prioridades. & \\
& & \\
\hline
\end{tabular}

Fonte: o autor, com base em Rogers, Sharp e Preece (2013, p. 67)

Quando transportamos este conceito para pessoas com deficiência visual, a audição e o tato podem ser utilizados como sentidos primários para a atenção. Norman (2006) relata que o som pode, inclusive, ter um significado mais eficiente na atenção, servindo até mesmo como interrupção ou desvio da atenção dispendida à visão em pessoas videntes (NORMAN, 2006, p. 132-133). 0 sentido do tato também pode servir para a atenção, quando a pessoa com deficiência visual recebe estímulos táteis para perceber a presença de objetos e pessoas nos ambientes (FELIPPE, 2001, p. 10-12) ou mesmo utilizando-se de ajudas eletrônicas com som e vibração para perceber a presença de objetos próximos (FELIPPE, 2001, p. 4). Para o desenvolvimento de interfaces eletrônicas, Rogers, Sharp e Preece citam a necessidade de facilitar a compreensão do usuário por meio da simplificação e ordenação dos elementos necessários para cada tarefa a ser realizada, destacando as informações relevantes para cada contexto e, preferencialmente, apresentando as informações na sequência da atividade, eliminando ou minimizando elementos desnecessários à tarefa. 


\subsubsection{PROCESSO DA PERCEPÇÃO}

- COM BASE EM ROGERS, SHARP E PREECE (2013, P. 71).

É um processo complexo, que se refere a como as pessoas interpretam e assimilam as informações recebidas pelos sentidos da visão, do tato e da audição, concatenando estas informações com outros processos cognitivos, como a memória, a atenção e a linguagem, caracterizando esta informação com experiências anteriores. Para interfaces digitais, percebe-se que a visão é o sentido predominante neste processo cognitivo, seguido da audição e do tato.

No desenvolvimento de interfaces, é importante apresentar as informações de maneira que possam ser interpretadas da forma pretendida e, para pessoas com deficiência visual, deve ser aprimorado para que a percepção não leve a dúvidas de interpretação. 0 quadro 2 ilustra os subsídios necessários no design para o processo da percepção, com base nos sentidos das pessoas e em suas ações relacionadas a estes sentidos.

Quadro 2 - Processo da percepção

\begin{tabular}{lll}
\hline Sentidos & Ações envolvidas & \multicolumn{1}{c}{ Subsídios para o design } \\
\hline Visão, & Obter uma & Utilizar símbolos reconhecíveis para o \\
audição e & informação do & usuário alvo, tornar visível a \\
tato. & ambiente. As ações & informação visual, escrever textos com \\
& dependem da & contraste e dimensões compatíveis, \\
& atenção, da memória & destacar a informação audível para \\
& e da linguagem. & sobrepujar o ruído do ambiente, \\
& posicionar a informação tátil ao \\
& alcance do corpo. \\
\hline
\end{tabular}

Fonte: o autor, com base em Rogers, Sharp e Preece (2013, p. 71)

O objetivo de fornecer informações ao usuário com deficiência visual, de forma a não deixar margens para dúvidas de interpretação se torna ainda mais importante quando a indicação está aplicada em um aparelho ou sistema que demanda de segurança de utilização, como um sistema de guia para que as pessoas com deficiência visual caminhem autonomamente em locais públicos repletos de riscos. Então, o processo cognitivo da percepção deve ser observado cuidadosamente, associando-o aos outros processos cognitivos, durante o desenvolvimento da interface. 


\subsubsection{PROCESSO DA MEMÓRIA}

- COM BASE EM ROGERS, SHARP E PREECE (2013, P. 72) .

Este processo está relacionado diretamente à capacidade das pessoas de se recordarem de fatos, objetos e ações já vividas anteriormente ou pelo conhecimento adquirido sobre a vivência de outras pessoas.

Sendo a memória relacionada à capacidade da lembrança, a possibilidade de sobrecarga do cérebro é grande, pois a todo o momento vemos, ouvimos, cheiramos, experimentamos e tocamos coisas, então, para que não ocorra esta sobrecarga, as sensações passam por filtros, que selecionam o que deve ser lembrado e o que deve ser esquecido. Este processo de filtragem talvez seja uma das ações mais complexas na execução do cérebro, e pode falhar quando, por exemplo, esquecemo-nos de situações que desejaríamos lembrar e nos lembramos de situações que desejaríamos nos esquecer.

Dentre diversos fatores utilizados pelo processo de filtragem das informações, o processo cognitivo da atenção tem relevância: quanto mais se presta atenção a um assunto ou situação, maior é a probabilidade de se refletir sobre ele, de discuti-lo com outras pessoas, de discorrer sobre ele e, consequentemente, a probabilidade de memorizá-lo é maior. 0 quadro 3 ilustra os subsídios necessários no design para o processo da memória, com base nos sentidos das pessoas e em suas ações relacionadas a estes sentidos.

Quadro 3 - Processo da memória

\begin{tabular}{lll}
\hline Sentidos & Ações envolvidas & \multicolumn{1}{c}{ Subsídios para o design } \\
\hline Visão, & Interpretação e & Elaborar ferramentas para \\
audição, tato, & reflexão sobre & reestabelecer situações e \\
paladar e & determinada situação, & informações, simplificar os \\
olfato. & recordações sobre & processos, promover a familiarização \\
& eventos conhecidos e & ao invés da necessidade de \\
& reação a situações & recordação, organizar a possibilidade \\
& conhecidas ou & de busca de informações, padronizar \\
& semelhantes. & informações e objetos interativos. \\
\hline
\end{tabular}

Fonte: o autor, com base em Rogers, Sharp e Preece (2013, p. 72) 
Para o desenvolvimento de interfaces, o processo da memória pode ser mais bem aproveitado se o cérebro não for sobrecarregado com informações e procedimentos complicados, promovendo o reconhecimento da informação por meio da reflexão ao invés da recordação direta, utilizando funções de comandos posicionados de forma lógica e fornecendo as informações em categorias de fácil reconhecimento. Relacionar os elementos da interface a elementos da vida real também é uma poderosa ferramenta, e sua simplificação é importante na busca pela memorização de seus elementos, principalmente quando o usuário tem os sentidos da audição e do tato como sentidos preferenciais ou exclusivos, tornando difícil a utilização quando um usuário com deficiência visual precisa usar uma interface com elementos exclusivamente visuais.

De acordo com Norman (2006, p. 96), os psicólogos citam dois tipos de memória: a memória de curto prazo e a memória de longo prazo. A memória de curto prazo é a mais importante para as tarefas do cotidiano. Sua principal vantagem é a capacidade de a pessoa recuperar rapidamente as lembranças nela contidas, mas apresenta duas desvantagens principais: a quantidade de informações que as pessoas são capazes de armazenar na memória de curto prazo é muito limitada, e as lembranças de curto prazo são extremamente frágeis, podem ser rapidamente esquecidas caso a pessoa seja interrompida ou sua atenção for desviada para outra tarefa.

Uma das implicações à usabilidade que precisam ser resolvidas é a sobrecarga de memória que as interfaces podem causar às pessoas. Então, procedimentos complicados, extensos ou com muitos passos podem se tornar rapidamente confusos. No campo da deficiência visual, a sobrecarga de memória em interfaces pode ser ainda mais prejudicial, pois os passos anteriores nas interfaces que exploram áudio e tato não estão disponíveis de forma rápida, implicando no repasse das informações de áudio ou buscando novamente com o tato uma informação passada.

Para Liben (1998), o wayfinding das pessoas com deficiência visual exige informações relacionadas à capacidade de memorização do ambiente, tais quais: conhecimento prévio sobre o espaço, estratégias específicas sobre o ambiente, 
lembrança de elementos presentes no espaço ou até mesmo semelhanças com ambientes que a pessoa esteja familiarizada. Assim, o processo da memória possui especial importância para a autonomia na orientação e mobilidade de pessoas com deficiência visual.

\subsubsection{PROCESSO DO APRENDIZADO}

- COM BASE EM ROGERS, SHARP E PREECE (2013, P. 81).

O aprendizado está relacionado à compreensão de determinada situação, e é um dos processos que fomentam a memorização. Existem situações que facilitam o aprendizado, e uma delas é a manipulação direta do objeto ou da situação, experimentando os resultados de cenários e acontecimentos derivados desta manipulação direta. 0 quadro 4 ilustra os subsídios necessários no design para o processo do aprendizado, com base nos sentidos das pessoas e em suas ações relacionadas a estes sentidos.

Quadro 4 - Processo do aprendizado

\begin{tabular}{lll}
\hline Sentidos & Ações envolvidas & Subsídios para o design \\
\hline Habilidades & Memorização de & Aprimorar os projetos, \\
individuais. & situações por meio da & disponibilizar experimentações \\
& compreensão, interação & exploratórias, criar \\
& com o objeto ou situação, & representações relacionais com \\
& experimentação de & objetos e situações cotidianas, \\
& processos, & minimizar os erros, facilitando a \\
& aperfeiçoamento pela & recuperação caso eles \\
& observação do processo e & ocorrerem, disponibilizar \\
& de seu resultado. & documentação e informação. \\
\hline
\end{tabular}

Fonte: o autor, com base em Rogers, Sharp e Preece (2013, p. 81)

O processo do aprendizado é muito utilizado nas técnicas de ensino de orientação e mobilidade. Felippe (2001) cita o aprendizado da utilização do estímulo tátil por pessoas com deficiência visual ao disponibilizar alguns recursos de manipulação de objetos com diversas texturas, pesos, tamanhos, formas, temperaturas, consistências e até mesmo cores, a manusear e construir mapas táteis, modelos e maquetes, a sentir o pelo e pele de animais empalhados e experimentar a funcionalidade de diversos outros tipos de materiais, além de estimular a cinestesia por meio da participação da pessoa em atividades físicas, esportivas e recreativas (FELIPPE, 2001, p. 37-38). 
Do lado do projetista de ambientes e interfaces, devem-se criar ferramentas que tornem as experimentações exploratórias mais ativas por parte do usuário, precavendo as situações de erro ao torna-las recuperáveis ou causadoras do menor prejuízo possível, além de informar ao usuário onde está o erro, informa também os motivos pelos quais ele ocorreu e fornece formas de corrigi-lo.

\subsubsection{PROCESSO DA LEITURA, FALA E AUDIÇÃO}

- COM BASE EM ROGERS, SHARP E PREECE (2013, P. 83).

Ler, falar e ouvir são os processos relacionados à propagação do conhecimento e da informação por meio de linguagens. Linguagens são formas de comunicar ideias, informações e sentimentos por meio de signos, símbolos e representações padronizadas, propagadas por meios visuais, sonoros e gestuais. 0 reconhecimento e reprodução de linguagens podem ser feitos por meio da leitura, da fala e da audição, relacionados aos sentidos do tato, da audição e da visão. A linguagem também faz uso de outros processos, como a memória e o aprendizado.

Por depender da memória e do aprendizado, a transferência do conhecimento ou da instrução precisa ser o mais sucinto possível, e deve seguir uma sequência lógica e de fácil acompanhamento, buscando a menor exigência de memorização. 0 quadro 5 ilustra os subsídios necessários no design para o processo da linguagem, com base nos sentidos das pessoas e em suas ações relacionadas a estes sentidos.

\section{Quadro 5 - Processo da linguagem}

\begin{tabular}{ccl}
\hline Sentidos & Ações envolvidas & \multicolumn{1}{c}{ Subsídios para o design } \\
\hline Visão, & Ler instruções, & Comunicar uma quantidade reduzida \\
audição e & tanto pela visão & de opções em cada passo da tarefa, \\
tato. & como pelo tato e & permitir a escolha de receber a \\
& ouvir instruções. & $\begin{array}{l}\text { informação por meio sonoro, tátil, } \\
\text { visual ou por mais de um meio, } \\
\end{array}$ \\
& aprimorar a qualidade do meio para \\
& garantir a compreensão da instrução. \\
\hline
\end{tabular}

Fonte: o autor, com base em Rogers, Sharp e Preece (2013, p. 83)

Os processos de linguagem podem sofrer interferências da complexidade da tarefa, do contexto, podem existir preferências individuais sobre utilizar um sentido ao invés do outro para receber a mesma informação. Esta necessidade pode ser suprida por meio da redundância das informações, disponibilizando-as por meio 
escrito, sonoro e, quando possível, por meio tátil, realizando-se variações de ajustes em cada meio para facilitar seu entendimento.

A linguagem é a forma que os projetistas de ambientes e interfaces podem utilizar para a comunicação bilateral entre o usuário e o recurso. Ao utilizar a linguagem em determinada interface, o projetista deve levar em conta que a linguagem falada é transitória, enquanto a escrita é menos volátil, o usuário pode, de forma rápida, reler a instrução, dispondo de sua atenção a trechos específicos da mensagem, enquanto que, na fala, a informação é passada de forma sequencial e sua compreensão depende do conhecimento de toda a instrução.

Dado à impossibilidade de informar situações dinâmicas às pessoas com deficiência visual por meio da linguagem escrita visual, pode-se dispender especial atenção à linguagem falada, que precisa ser direta e sintética, pois informações vocais muito complexas ou extensas podem levar a falhas de memorização. Além disso, as informações vocais devem apresentar boa entonação e fornecer um volume suficiente para a audição, oferecendo clareza e qualidade.

\subsubsection{RACIOCÍNIO E TOMADA DE DECISÕES}

- COM BASE EM ROGERS, SHARP E PREECE (2013, P. 84).

Os processos de raciocínio, tomada de decisões e suas resultantes, como a capacidade de planejamento e de resolução de problemas, implicam em pensar no que fazer, na reflexão sobre o assunto, é integrantes da cognição reflexiva. Normalmente envolvem processos conscientes, fazem uso intenso de todos os outros processos cognitivos e utilizam a capacidade argumentativa para discutir opções com terceiros e consigo mesmo.

O grau de empenho que uma pessoa dispende ao raciocínio e à tomada de decisão é dependente de seu domínio sobre o assunto. As pessoas com pouco domínio tendem a realizar associações com assuntos aparentemente correlatos (processo da memória), resolvendo os problemas pelo método da tentativa e erro (processo do aprendizado). É provável que cometam muitos erros e, dependendo do grau de dificuldade do problema, o avanço para a solução pode ser lento e ineficiente. Também podem agir de forma irracional, seguindo paradigmas, sem o 
planejamento em longo prazo. Por outro lado, os especialistas são capazes de selecionar estratégias e métodos para solucionar cada passo da tarefa, planejando o curto, o médio e o longo prazo, atingindo o resultado esperado de forma mais rápida, eficiente e definitiva. 0 quadro 6 ilustra os subsídios necessários no design para o processo da percepção, com base nos sentidos das pessoas e em suas ações relacionadas a estes sentidos.

Quadro 6 - Processo do raciocínio

\begin{tabular}{lll}
\hline \multicolumn{1}{c}{ Sentidos } & Ações envolvidas & \multicolumn{1}{c}{ Subsídios para o design } \\
\hline Todos os & Análise do & Possibilitar o acesso de informações \\
processos & problema, tomada & adicionais sobre as funções e o \\
cognitivos. & de decisões, & processo e disponibilizar funções \\
& planejamento e & descomplicadas, de fácil \\
& reflexão, & memorização, que apoiem o \\
& consciência, & planejamento e a tomada de decisão. \\
& capacidade & \\
& argumentativa. & \\
&
\end{tabular}

Fonte: o autor, com base em Rogers, Sharp e Preece (2013, p. 84)

A disponibilização de informações descomplicadas e precisas facilita na tomada de decisões, e a presença de informações mais completas, para acesso adicional opcional, estimula o aumento da eficiência para a finalização do processo, preferencialmente se esta informação adicional forneça subsídios de fácil utilização por pessoas com pouca experiência.

Ao se transportar os processos cognitivos para a orientação e mobilidade de pessoas com deficiência visual, pode-se incrementar tanto as formas de treinamento quanto buscar melhorias para os recursos de acessibilidade e tecnologias assistivas. Observam-se diversos pontos em comum nas sugestões para o design na análise de Rogers, Sharp e Preece que podem ser unificados e readequados, possibilitando a melhor compreensão das relações entre as necessidades do usuário e a contribuição que o design da interface pode fornecer. Estas relações podem ser vistas no infográfico 1, página 77. 
Infográfico 1 - Interfaces: necessidades do usuário x subsídios do design Necessidades do usuário Subsídio fornecido pelo design

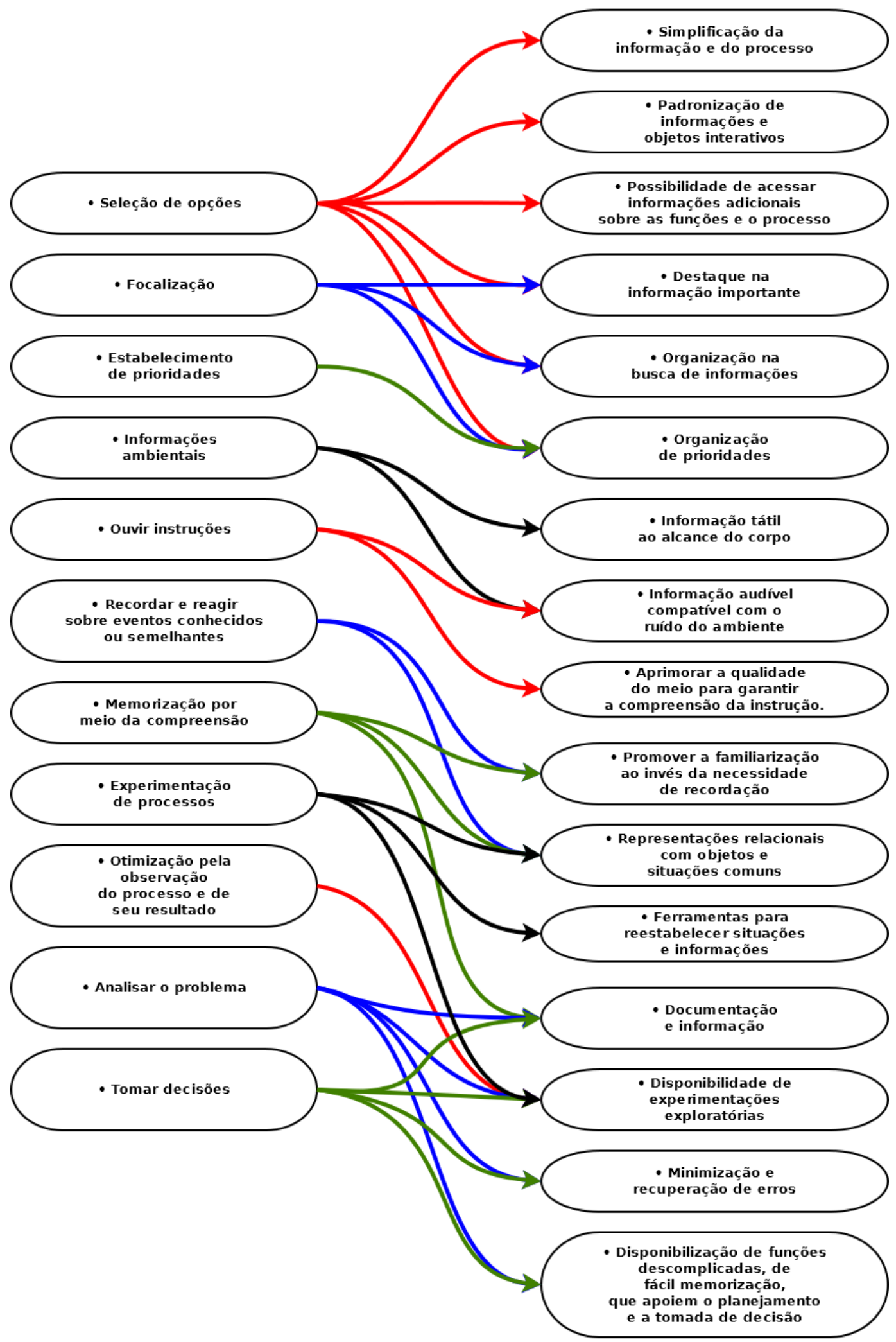

Fonte: o autor, com base em Rogers, Sharp e Preece (2013) 
Pode-se considerar que as informações táteis e sonoras, apesar de não exclusivas, são pré-requisitos do design de interfaces para pessoas com deficiência visual. Dentre os itens mostrados no infográfico 1 (página 77 ) relacionados à disponibilidade destas necessidades que criam modalidades específicas de informação, observa-se que as necessidades para o design associadas às informações táteis e sonoras não influenciam diretamente no design comum em quaisquer interfaces, posto que os únicos requisitos sejam o cuidado com a distância das informações táteis e com a qualidade das informações audíveis. 0 infográfico 2 ilustra esta parte específica do infográfico 1 da página 77, demonstrando que o design para pessoas com deficiência visual pode estar contido em todos os projetos de interfaces, corroborando com a filosofia do design universal.

Infográfico 2 - Modalidades de processos cognitivos importantes para o design de interfaces para pessoas com deficiência visual

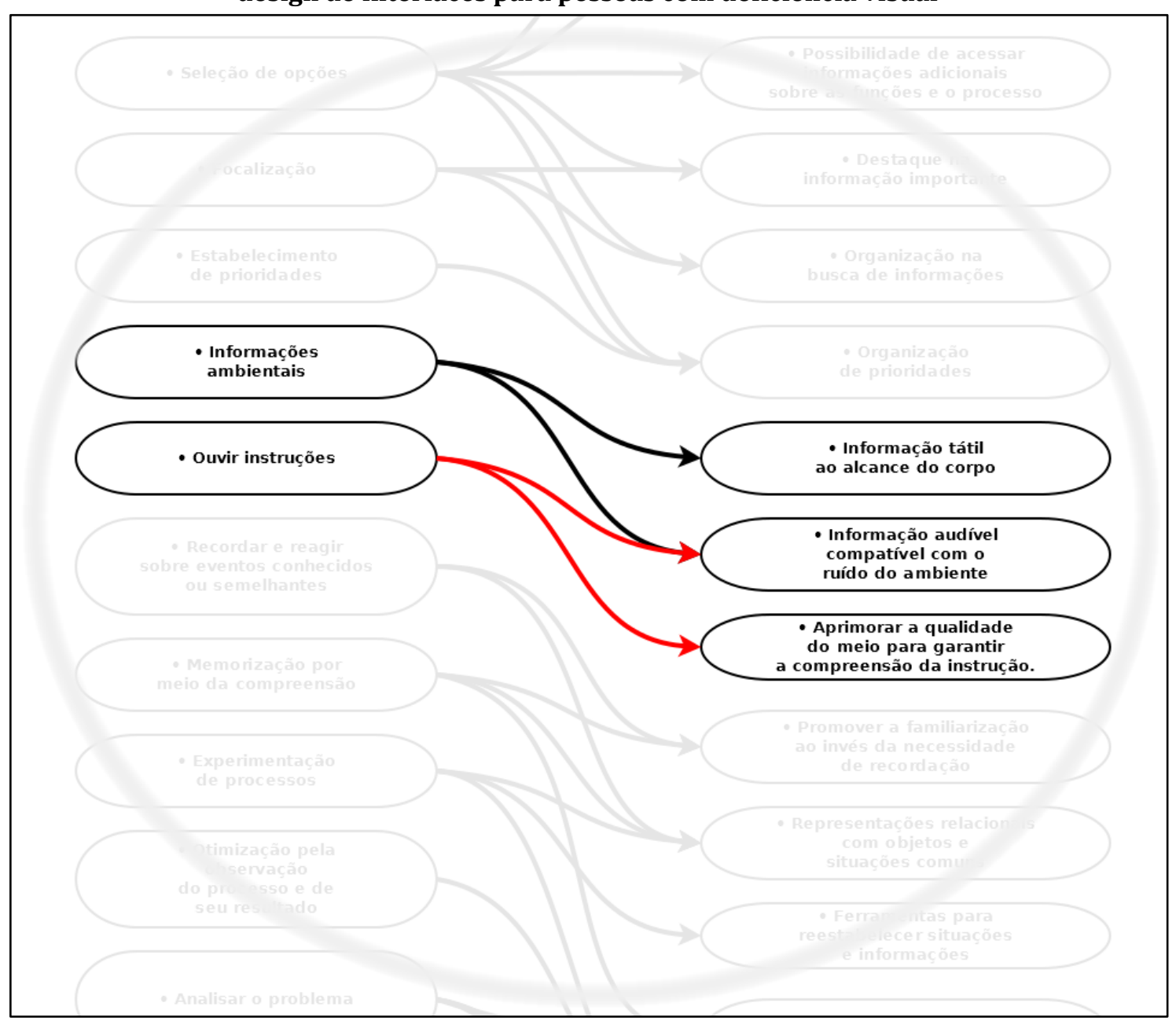

Fonte: do autor, com base em Rogers, Sharp e Preece (2013) 
Todos os aspectos da interface devem ser observados durante o seu desenvolvimento, mas, quando o foco é o usuário com deficiência visual, o designer precisa considerar a disponibilização de todas as informações para o usuário por meio das modalidades relacionadas no infográfico 2 da página 78, pois não há possibilidade de redundância de informação por meio visual.

\subsection{RELAÇÕES ENTRE SOM E IMAGEM PARA O DESIGN DE INFORMAÇÃO}

De acordo com Redig (2004, p. 66), a informação é fundamental para a cidadania, e não há informação sem design. 0 design é uma ferramenta fundamental para atender as necessidades das pessoas, por meio de interfaces bem planejadas e construídas. 0 planejamento eficiente do design da interface é o que dá poder ao usuário, pois oferece a ele toda a potência que o produto pode oferecer. 0 design na informação funciona da mesma forma, pois quando é corretamente planejado, possibilita total conhecimento do usuário sobre a informação presente.

Bonsiepe (1999), Braga (2004) e Bevilacqua (2007) citam que a interface é o meio interativo que proporciona ao usuário a capacidade de uso da ferramenta, possibilitando a realização das ações (figura 7).

\section{Figura 7- A interface}

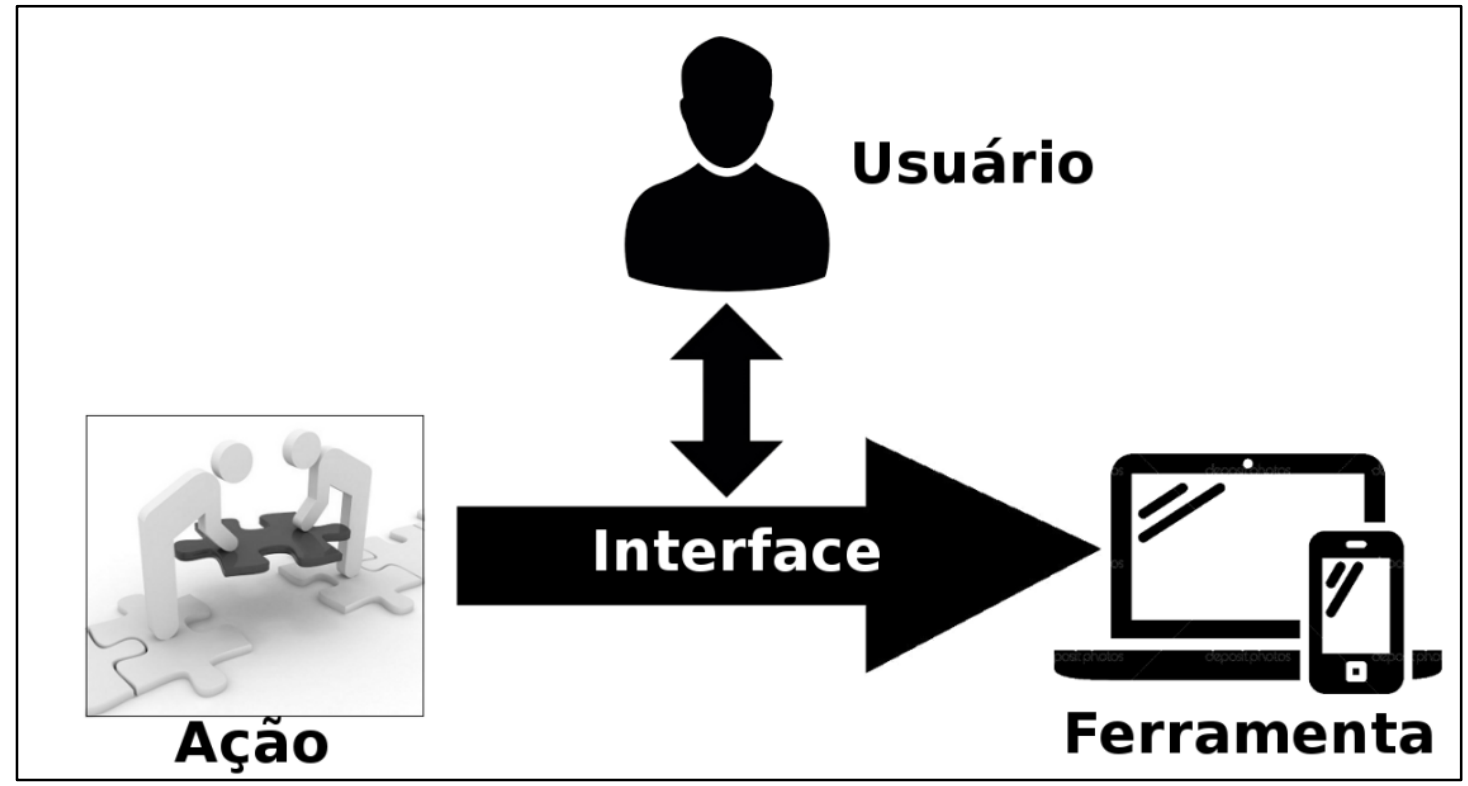

Fonte: o autor, com base em Bonsiepe (1999) 
O design da informação é a interface entre o usuário e a mensagem. Redig (2004) elenca algumas exigências para o design da informação, considerando a mensagem transmitida, o destinatário, o formato e o tempo da transmissão como preceitos básicos para o processo da comunicação. Ignorar estes preceitos é um caminho para tornar imperfeito o processo da comunicação, desfavorecendo as necessidades das pessoas. Além disso, Baumann (2010) alerta para a necessidade de se criar um sistema de comunicação compreensivo, claro e consistente, oferecendo informações focadas e relevantes para que o usuário possa usar a informação de forma eficiente, criando um sistema de comunicação visual compreensivo, claro e consistente, com mensagens concisas. Baumann (2010) também cita duas diretrizes básicas para a comunicação:

5) mostrar informações que são relevantes para guiar, localizar ou navegar no espaço em questão;

6) remover a informação excessiva, tirando elementos desnecessários para criar um ambiente visual limpo.

Toda comunicação é realizada a partir de algo ou alguém que origina a mensagem até algo ou alguém que a recebe. 0 design de informação precisa considerar não somente a mensagem e a origem, mas principalmente quem recebe a informação, pois, para que a comunicação se estabeleça, a informação fornecida pelo emissor precisa ser compreendida pelo receptor, então o receptor é o foco para a criação da informação (REDIG, 2004, p. 62). Assim, para criar a linguagem da interface, o designer de informação precisa personificar-se na figura de quem vai receber a mensagem.

Para que a comunicação se estabeleça, precisa existir uma analogia com seu conteúdo, planejando sua linguagem para as pessoas as quais este conteúdo se destina, fornecendo clareza e rapidez no seu entendimento, pois, de acordo com Redig (2004, p. 62) a informação é mais bem compreendida pelo receptor quando esta é aplicada de forma análoga pelo designer. 
O ser humano utiliza cinco sentidos principais para reconhecer o mundo: visão, audição, olfato, paladar e tato, todos relacionados a um ou mais órgãos sensores do corpo, cujos principais são os quimiorreceptores, os fotorreceptores, os mecanorreceptores e os fonorreceptores. Os quimiorreceptores são os responsáveis por receber estímulos químicos, como o olfato e o paladar. Os fotorreceptores percebem os estímulos luminosos, e estão localizados nos olhos. Os mecanorreceptores percebem estímulos mecânicos, como pressão e toque, e estão localizados por todo o corpo humano, predominantemente sob a pele. Os fonorreceptores também percebem estímulos mecânicos relacionados à pressão, mas conseguem perceber estas informações em uma sensação diferente do toque, traduzindo-as em sons (SANTOS, 2016).

Assim como os fotorreceptores nos olhos podem perceber estímulos visuais que nos permitem reconhecer informações por meio de cores, formas e contrastes, fornecendo linguagens visuais, como símbolos, e sensações visuais por meio da segregação, unidade, unificação, fechamento, continuação proximidade e semelhança dos objetos, os fonorreceptores nos ouvidos nos permitem reconhecer informações auditivas por meio de frequência, período e amplitude, fornecendo o reconhecimento de linguagens sonoras, como os sons que representam a língua, e sensações sonoras por meio da harmonia, da tonalidade e da melodia.

As características dos órgãos humanos que percebem estímulos visuais oferecem informações diferentes dos órgãos que percebem estímulos auditivos, inexistindo uma tradução direta entre as sensações visuais e auditivas. Conforme Baxter (2011, p. 48), o design de sinalização e de interfaces possui natureza predominantemente visual, por este motivo a maioria das características dos elementos visuais não possuem equivalentes nas características sonoras. No entanto, conforme Norman (2006, p. 132-133), é possível associar algumas características físicas do som com características da imagem, criando uma similitude que transfira as sensações que uma imagem possa representar por meio do uso do som, concebendo-se assim uma tradução, mesmo que indireta, das informações visuais para o domínio das informações sonoras. 
O som é o movimento vibratório que se propaga por um meio físico, seja este meio um sólido, um líquido ou gás. Ocorre quando o meio recebe um esforço que abala ou perturba sua condição física, e a energia cinética causada por esta perturbação trafega pelo meio físico, até a energia propagada atingir o final ou dissipar-se (FERNANDES, 2002, p. 9).

As pessoas percebem o som por meio da vibração que chega aos ouvidos, predominantemente pelo ar. Essas vibrações agem nos órgãos auditivos do ouvido médio (SPADA, 2015, p. 1; RUI e STEFFANI, 2007, p. 3). A vibração do ar atravessa o canal auditivo, chegando ao ouvido médio (figura 8) e são transmitidos ao cérebro.

Figura 8 - 0 ouvido humano

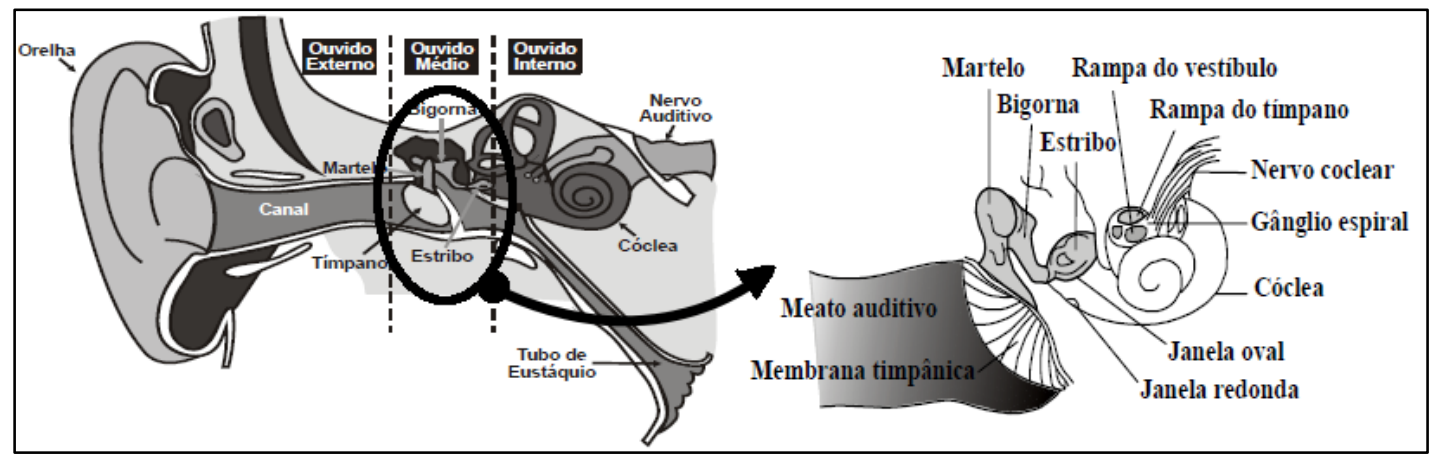

Fonte: Spada (2015, p. 1)

A pressão mecânica só é percebida pelo ouvido humano, recebendo a atribuição de som, caso a frequência esteja compreendida entre $20 \mathrm{~Hz}$ (vinte mudanças de estado por segundo) até os $20 \mathrm{mil} \mathrm{Hz}$ (20 MHz, ou vinte mil mudanças de estado por segundo), pois estes são os limites de frequência da pressão mecânica que os órgãos do ouvido humano conseguem perceber e decodificar (RUI e STEFFANI, 2007, p. 3).

Quaisquer frequências de variação de pressão abaixo dos $20 \mathrm{~Hz}$ são consideradas infrassons, ou frequências abaixo do som, e frequências acima dos 20 mil Hz são consideradas ultrassons, ou frequências acima do som. Assim, tudo o que o ser humano ouve, como músicas, fala, ruídos, apitos alarmes, assovios, etc. possuem frequências entre os 20 e os $20 \mathrm{mil} \mathrm{Hz}$. A intensidade de pressão é importante para a percepção dos sons, pois define se a frequência dentro da faixa audível tem 
intensidade suficiente para ser ouvida e se está abaixo do limiar onde a pressão passa a ser tão intensa que começa a se tornar perigosa para a saúde.

A figura 9 demonstra as regiões de sons que compreende toda a faixa de voz e música, desde os limiares de baixa pressão até os limites onde os seres humanos podem sentir dor nos ouvidos, além da possibilidade de sofrerem danos físicos e psicológicos.

Figura 9 - Faixa sonora humana

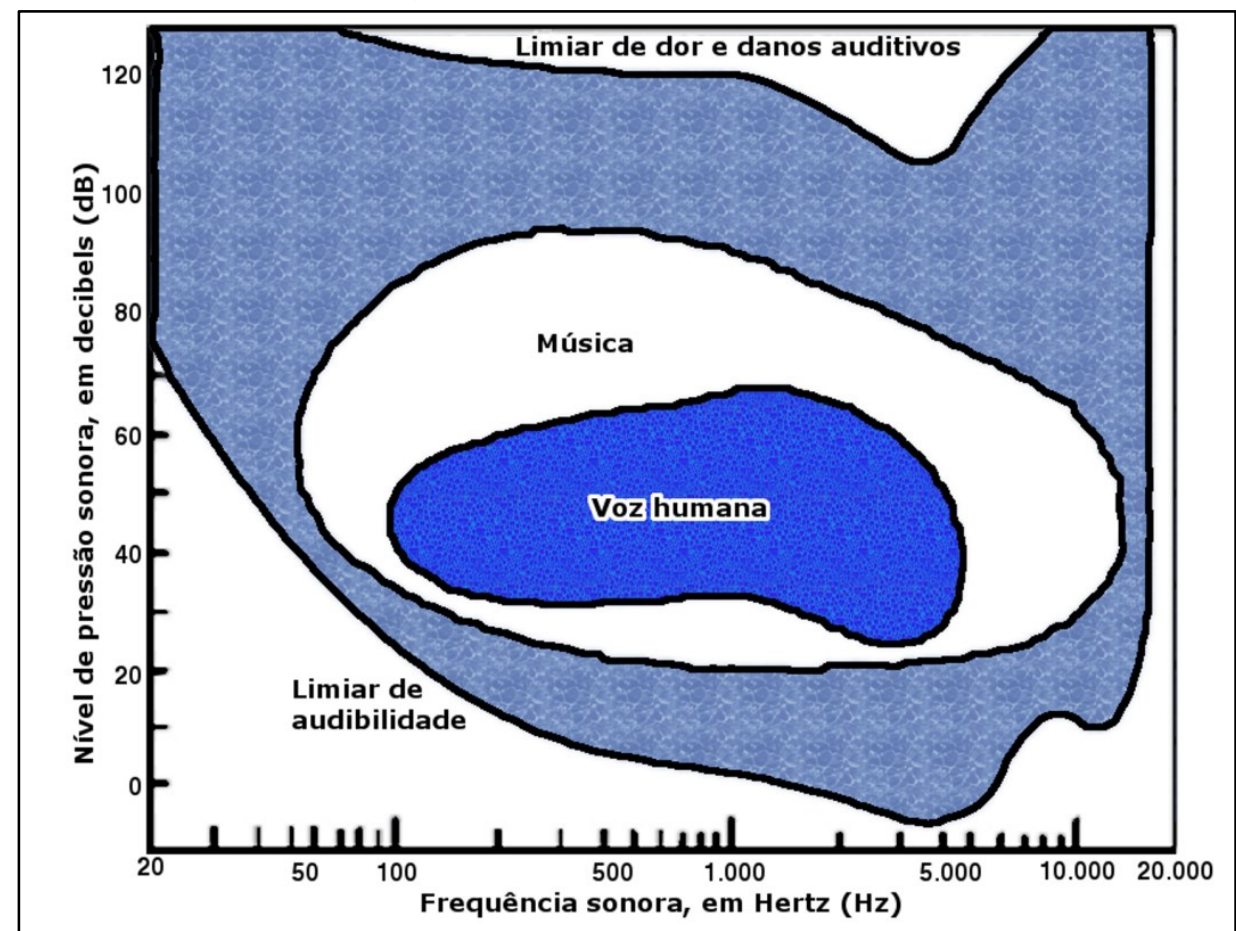

Fonte: Medeiros (2002).

As características principais do som são frequência e amplitude, e estão relacionados diretamente a qualidades físicas que as ondas sonoras podem assumir, como velocidade, direção, amplitude e período. A frequência refere-se à quantidade de vibrações de pressão por segundo, está relacionada às qualidades de velocidade e período da onda, enquanto que a amplitude se refere à força desta pressão, e está relacionada à intensidade e direção da onda. 
A frequência pode ser medida em $\operatorname{Hertz}^{6}$ (símbolo $\mathrm{Hz}$ ), sendo que $1 \mathrm{~Hz}$ significa uma mudança de pressão por segundo. Já a intensidade, também conhecida por volume ou altura, possui certa complexidade de mensuração, pois envolve uma combinação de medidas de pressão com componentes da percepção humana sobre volume ou intensidade sonora. De acordo com Medeiros (2002, p. 4), esta medida pode ser resumida como pressão sonora, e sua unidade é o decibel (símbolo dB). A figura 10 é uma representação visual de frequência e amplitude.

Figura 10 - Frequência e amplitude

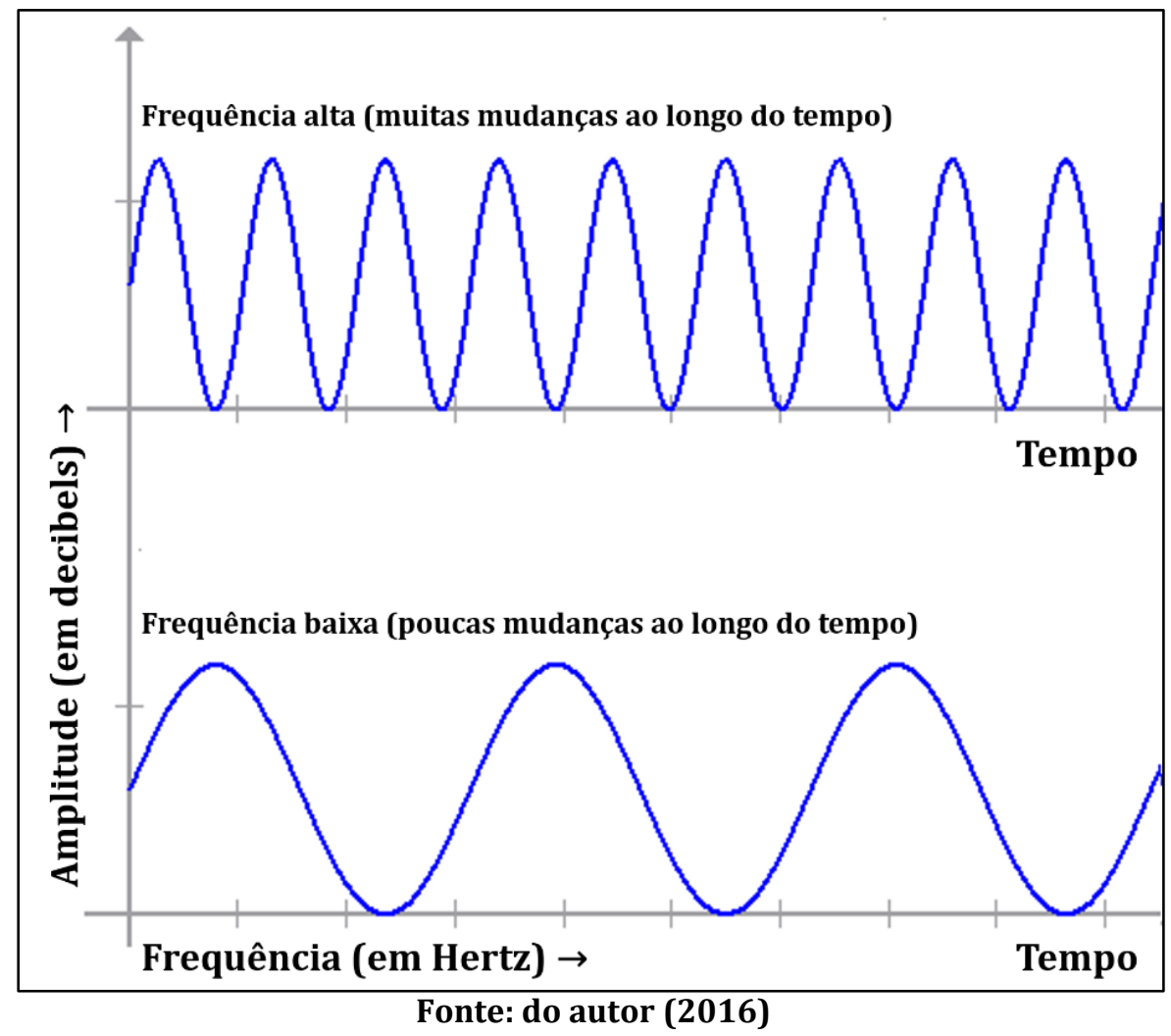

6 A unidade de frequência possuía a nomenclatura "cycles per second" ou "ciclos por segundo" (CPS) até 1960, quando a 11a Conferência Geral de Pesos e Medidas em Paris, França, 1960, substituiu o termo "CPS" pelo termo "Hertz" (Hz) (ALVAREZ e ALVAREZ, 2008). 0 termo Hertz foi adotado em homenagem ao físico alemão Heinrich Rudolf Hertz, que fez grandes contribuições científicas na área do eletromagnetismo. 
Há ainda outra relação que pode ser encontrada entre informações visuais e sonoras: a sensação de textura. Conforme Fabbri (2013) sons cujas ondas de pressão possuem formato senoidal, arredondadas, transmitem a sensação de suavidade, sensação de superfície lisa, enquanto que sons cujas ondas de pressão tendem a formatos com cantos vivos são mais agressivas aos ouvidos, transmitindo uma sensação de rugosidade. Quanto mais agudos os ângulos da onda sonora, maior é a sensação de rugosidade. As representações gráficas destes tipos de ondas podem ser visualizadas no quadro 7.

Quadro 7 - Representação gráfica de diferentes ondas de frequência

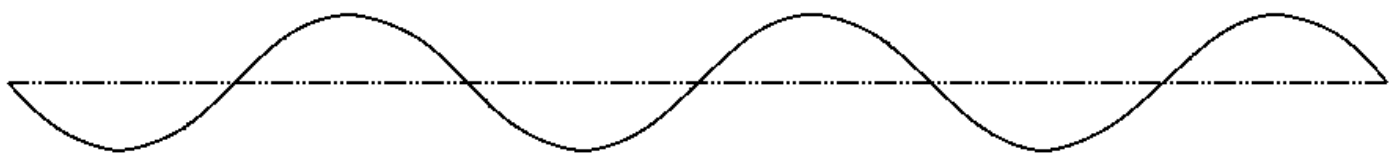

Onda senoidal

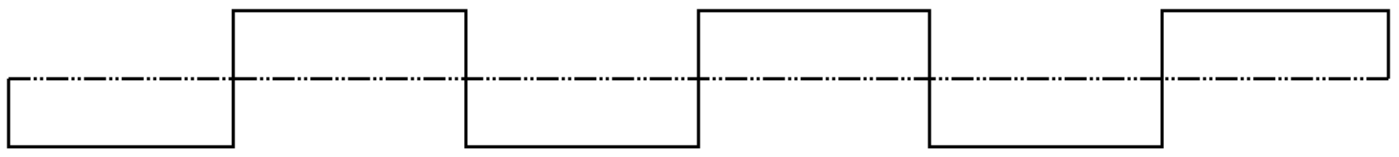

Onda quadrada

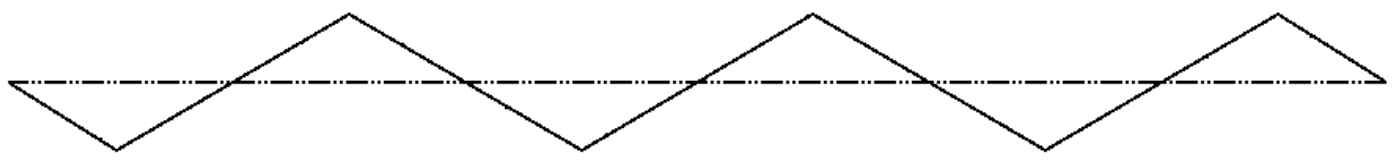

Onda triangular

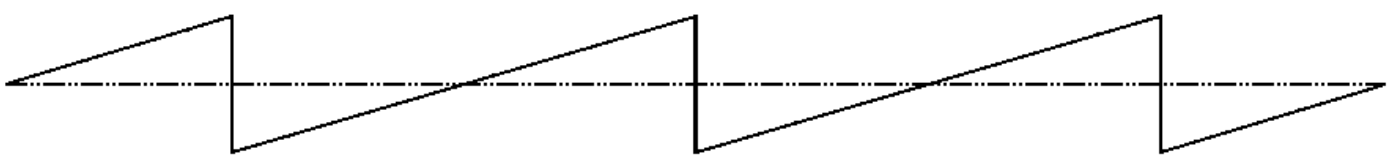

Onda "dente de serra"

Fonte: do autor (2016) com base em Fabbri (2013).

Tanto a frequência como a amplitude de uma vibração sonora pode ser somada ou subtraída com outras vibrações, criando outros formatos que são percebidos de forma composta pelo ouvido humano. De acordo com Joris, Schreiner e Rees (2004), a somatória de amplitudes de frequências sonoras é chamada de Amplitude Modulada (AM). 
0 quadro 8 demonstra graficamente um exemplo de soma de frequências em vibrações sonoras.

Quadro 8 - Somando frequências e amplitudes do som

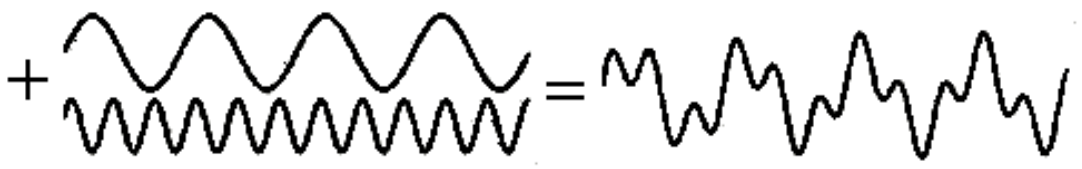

Somatória de duas frequências (baixa + alta frequência)

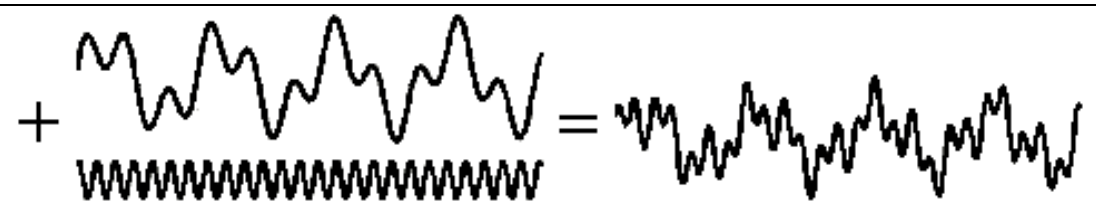

Somatória de três frequências (resultado anterior + alta frequência)

Fonte: do autor (2016) com base em Fernandes (2002).

Se a quantidade de frequências somadas for grande, ocorre uma indefinição de frequência principal. Para Fernandes (2002, p. 28), quanto mais se somam frequências, mais o som resultante vai se tornando uma mistura que o transforma em um tipo peculiar: o ruído, que é um som que não possui frequência definida. Para a percepção humana, o ruído se apresenta como um chiado (JORIS, SCHREINER e REES, 2004). Pode-se citar como exemplos de ruído o som resultante de um rádio fora de sintonia, muitas pessoas falando em um local amplo ou um trem entrando em uma estação subterrânea de metrô.

Assim como as imagens são percepções luminosas que representam um cenário com os objetos reais, os sons são uma representação auditiva de ações mecânicas que os objetos produzem. Tanto as percepções visuais como as auditivas podem ou não estarem de acordo com a realidade, pois são interpretações que o cérebro produz por meio dos processos cognitivos, com base nas sensações visuais e sonoras recebidas pelos olhos e ouvidos. Sendo os processos cognitivos o ponto comum na percepção do ambiente, este estudo busca correlações entre a forma de interpretação visual com a forma de interpretação auditiva. 
Uma das formas de estudo da percepção visual é a abordagem da Gestalt. Por meio do estudo da Gestalt, podem-se encontrar preceitos de interpretação da realidade visual mediante a percepção dos diversos elementos presentes nas imagens. De acordo com Hoffman (1998, p. 80), apesar de a percepção visual dispor da capacidade de captar uma imagem completa, o processo de interpretar o contexto da imagem não é instantâneo. Um exemplo citado por Hoffman é a experiência do neuropsicólogo H. Richard Tyler com sua voluntária "Senhora W". Nesta experiência, datada do final da década de 1960, Tyler apresenta, algumas vezes, uma imagem desenhada à Sra. W. Esta imagem está apresentada na figura 11.

Figura 11 - Imagen utilizada na pesquisa de H. Richard Tyler

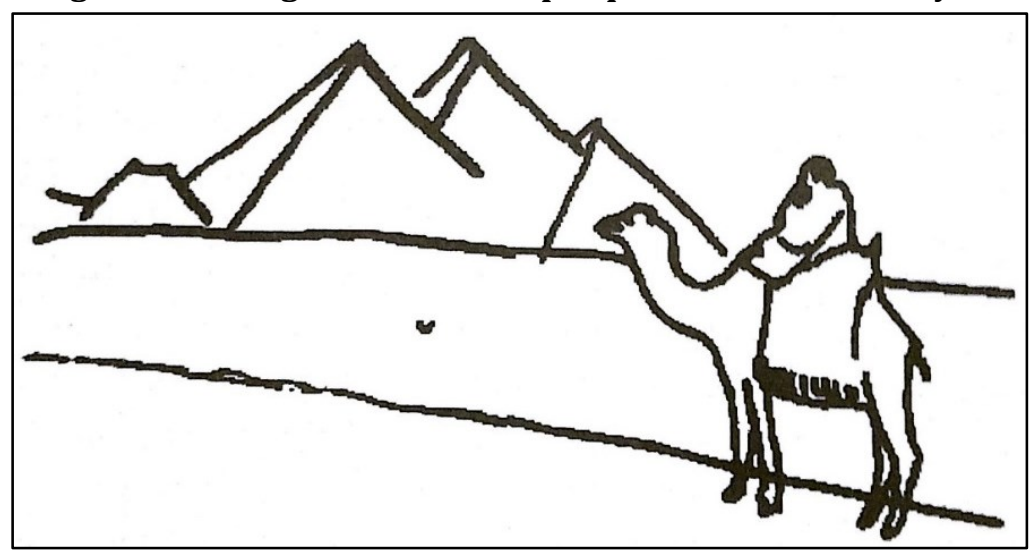

Fonte: Hoffman (1998, p. 80)

Na primeira vez que Tyler apresentou a imagem, a Senhora W pôde visualizá-la por seis segundos. Ao ser questionada sobre o a imagem, a Senhora W disse "uma montanha". Mostrada a imagem uma segunda vez, por dois segundos, a resposta foi "um homem", sem citar o camelo e sem demonstrar que a imagem vista por dois segundos era a mesma da primeira vez. Somente após visualizar a imagem por trinta segundos que a Senhora W contextualizou a cena, informando ser um homem em um camelo observando montanhas.

Esta experiência de Tyler, citada por Hoffman (1998, p. 79-80), sugere que as pessoas vêm o mundo por partes, contextualizando o que é de seu interesse somente após certo tempo observando determinada situação, contextualizando a informação na medida em que a mente processa cada elemento presente na cena. De acordo com Gomes Filho (2008), esta é a teoria geral da Gestalt. Similarmente, a linguagem falada também carrega informações complexas, compostas de diversas partes, mas com uma diferença: a linguagem verbal é sequencial, a informação da 
linguagem não existe de forma imediata, apesar da compreensão e interpretação da mensagem depender da execução de toda a sequência verbal. Assim, a interpretação da linguagem falada torna-se análoga à interpretação dos contextos obtidos por meio da visão, pois a fala entrega a informação por partes ao cérebro, provendo o tempo necessário para que a informação seja interpretada.

Hoffman (1998) cita que os objetos ou elementos visuais podem ser percebidos por meio da morfologia espontânea, contextualizando o tema da imagem na medida em que os elementos são identificados, por meio da segregação e da unidade destes elementos. Como exemplo desta característica da Gestalt, Hoffman demonstra a figura ambígua do vaso ou da face espelhada: segregando-se a imagem branca, percebe-se uma unificação que permite a identificação do vaso. Em contrapartida, segregando-se a imagem escura, percebe-se uma unificação que permite a identificação da face espelhada (figura 12).

\section{Figura 12 - Segregação e a unidade: morfologia espontânea}

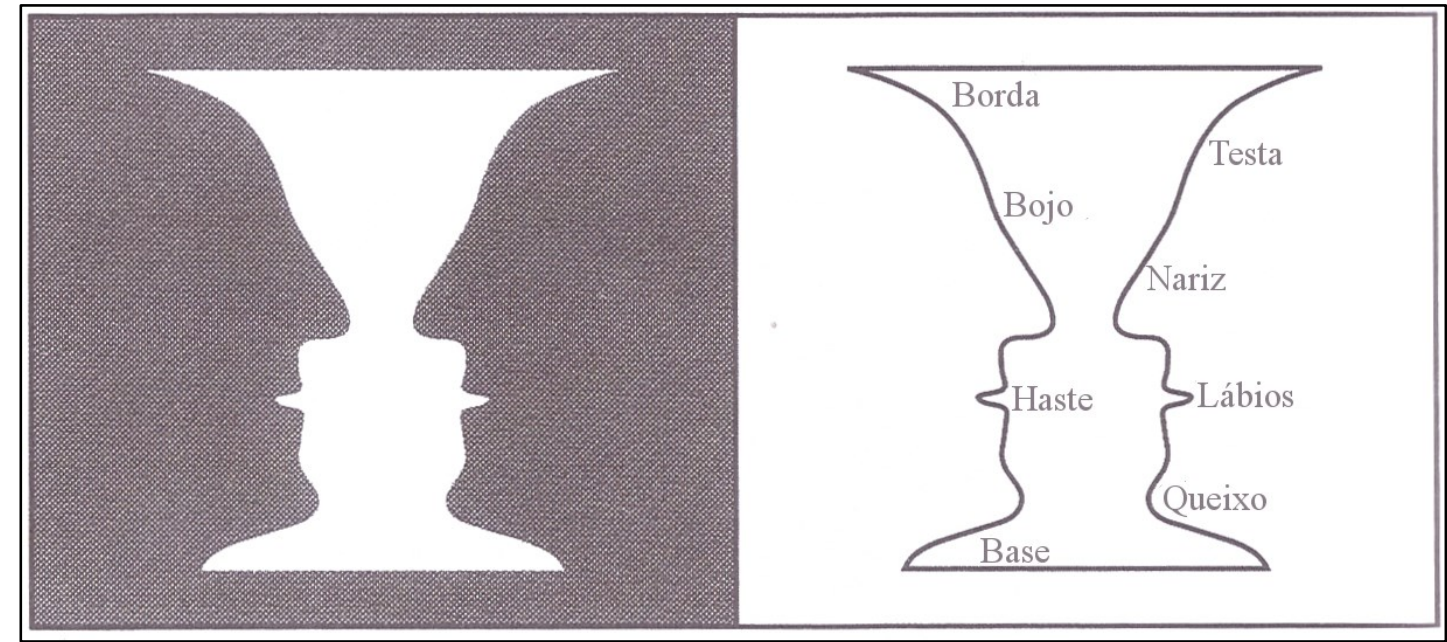

Fonte: Hoffman (1998, p. 92), com tradução pelo autor

Pelo mesmo princípio da morfologia visual espontânea, as frequências sonoras, tons, notas musicais e as construções verbais podem representar uma parte ou o todo de uma composição auditiva complexa. 0 reconhecimento dos sons depende de quase todos os processos cognitivos, como a atenção e a percepção para captar o som, a memória e o aprendizado para a formação de familiaridade e o processo da linguagem para a interpretação da mensagem. 
Desta forma, uma informação verbal falada pode ser interpretada com base na junção de seus elementos. Além disso, de acordo com Koch e Travaglia (2011, p. 40), o reconhecimento dos elementos das informações verbais também depende do universo cognitivo dos usuários receptores da mensagem, sem o qual a interpretação pode ser incompleta ou pode representar várias informações diferentes, análogo à unificação dos elementos visuais demonstrada por Hoffman (1998, p. 92).

Além disso, as informações por áudio precisam ser transmitidas de forma a prevalecerem sobre o ruído dos ambientes. Esta sobreposição pode ser feita por meio do realce do áudio da mensagem, combinando-se timbres e volumes sonoros, utilizando métodos análogos à pregnância da forma no design visual.

Para Gomes Filho (2008), Lupton e Phillips (2008), e Hoffman (1998), a pregnância da forma está relacionada à organização adotada na representação visual. A representação visual contém formas e fundos, os quais podem ser análogos à mensagem e ao ruído no domínio do áudio. Dependendo do modo com que a imagem é apresentada, pequenos detalhes na forma definem a importância do fundo, podendo, inclusive, tornar o fundo mais importante que a própria forma. Hoffman exemplifica este efeito da Gestalt por meio da figura 13, que apresenta três formas. A primeira e a terceira representação evidenciam uma forma inexistente e triangular de fundo, enquanto a representação central faz evidência aos três semicírculos. A diferença é que os semicírculos da representação central estão completos, enquanto os semicírculos das representações esquerda e direita estão abertos. Os semicírculos abertos tornam mais fáceis a visualização dos triângulos inexistentes.

Figura 13 - Pregnância da forma

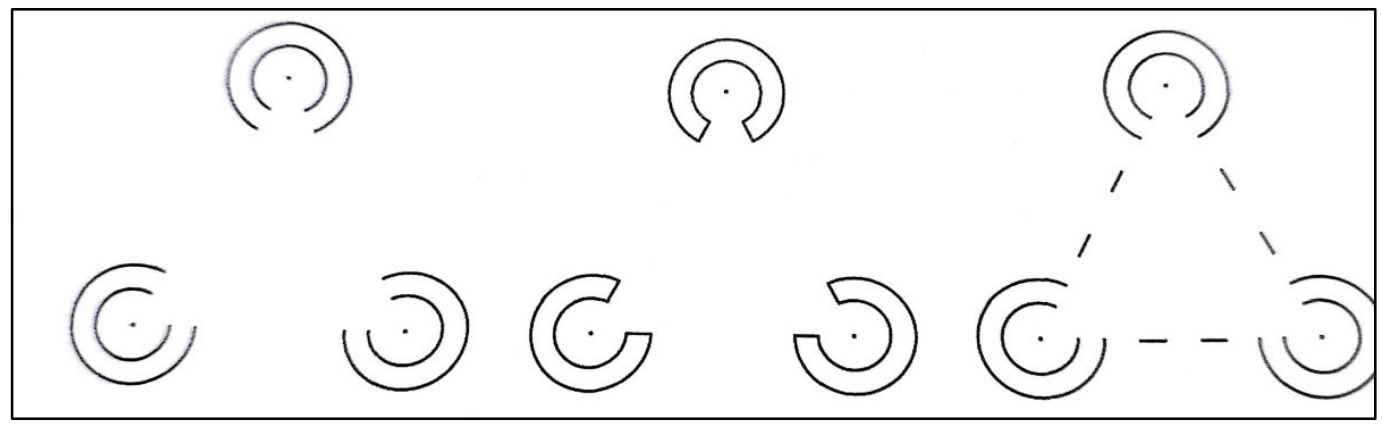

Fonte: Hoffman (1998, p. 63) 
Uma das formas de separar uma informação de um ruído, nos domínios do áudio, referenciando analogamente a pregnância da forma da Gestalt, é diferenciar a amplitude da informação com relação à amplitude do ruído, fazendo com que a informação prevaleça. Pode-se realizar esta ação por meio da redução do volume sonoro do ruído ou por meio do aumento do volume sonoro da informação. Desta forma, o áudio resultante da somatória do ruído com a informação tenderá para o reconhecimento da informação. As figuras 14 a 16 exemplificam este processo de contraste do som. A figura 14 representa graficamente uma forma de ruído ambiente:

Figura 14 - Representação gráfica de um ruído ambiente

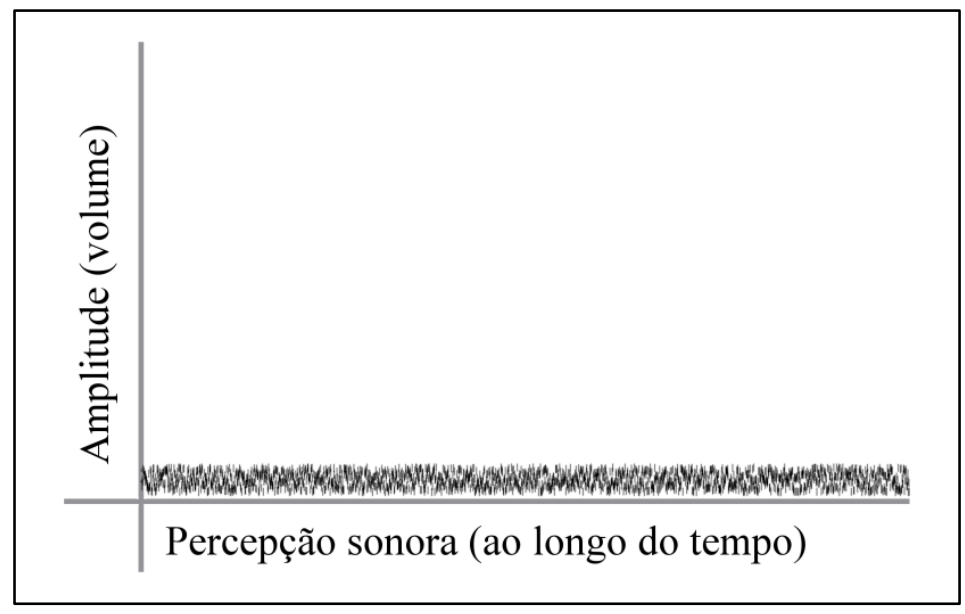

Fonte: do autor (2017)

A figura 15 representa a informação a ser transmitida. Nota-se que a amplitude da informação é muito maior que a amplitude do ruído representado na figura 15:

Figura 15 - Representação gráfica de uma informação sonora

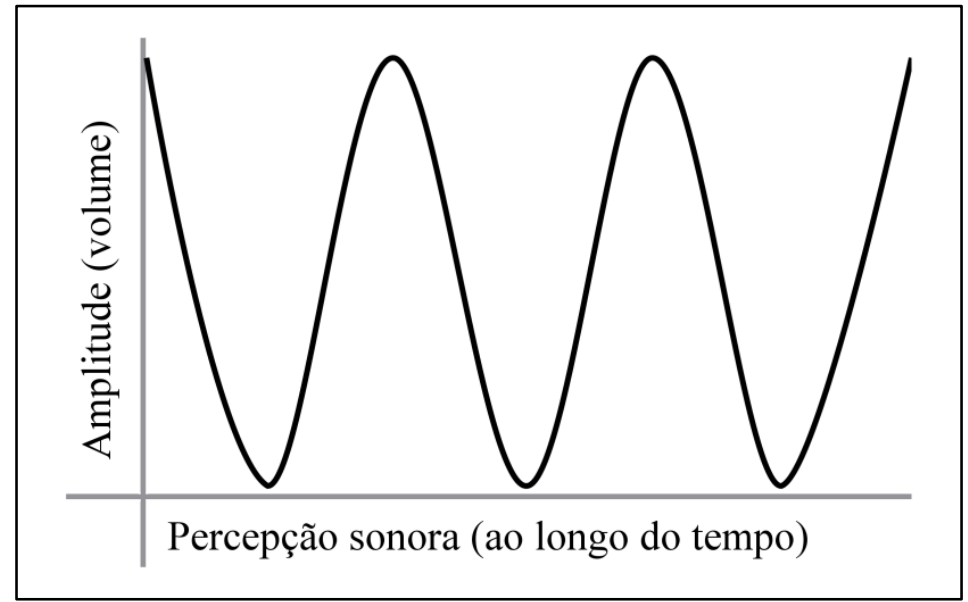

Fonte: do autor (2017) 
A percepção da pessoa que está ouvindo a informação e o ruído corresponde a uma somatória de ambos os áudios, representada na figura 16:

Figura 16 - Representação gráfica de uma informação sonora somada ao ruído

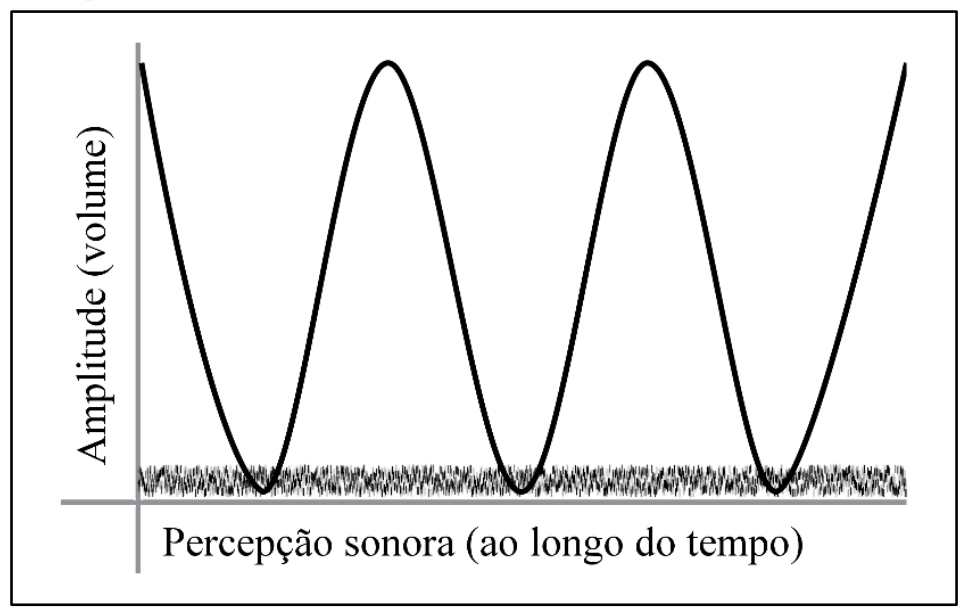

Fonte: do autor (2017)

Nota-se ainda a presença tanto do ruído como da informação. No entanto, a amplitude da informação torna-a predominantemente distinta do ruído, pois seu formato de onda continua evidente e prevalece sobre o ruído.

Se o processo fosse o oposto, ou seja, a informação tivesse menor amplitude sonora em relação ao ruído, este último prevaleceria, mesmo que a informação ainda possa ser discretamente percebida. As figuras 17, 18 e 19 exemplificam esta situação.

A figura 17 representa um ruído com grande volume sonoro:

Figura 17 - Representação gráfica de um ruído com grande volume sonoro

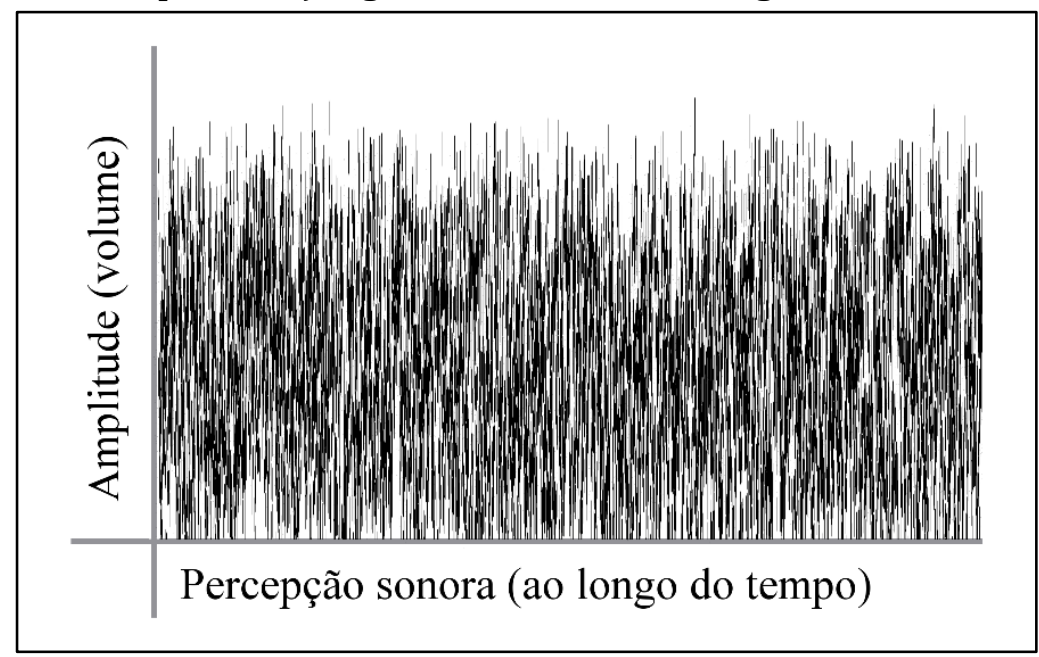

Fonte: do autor (2017) 
A figura 18 representa uma informação com volume sonoro inferior ao ruído representado na figura 17 (página 91):

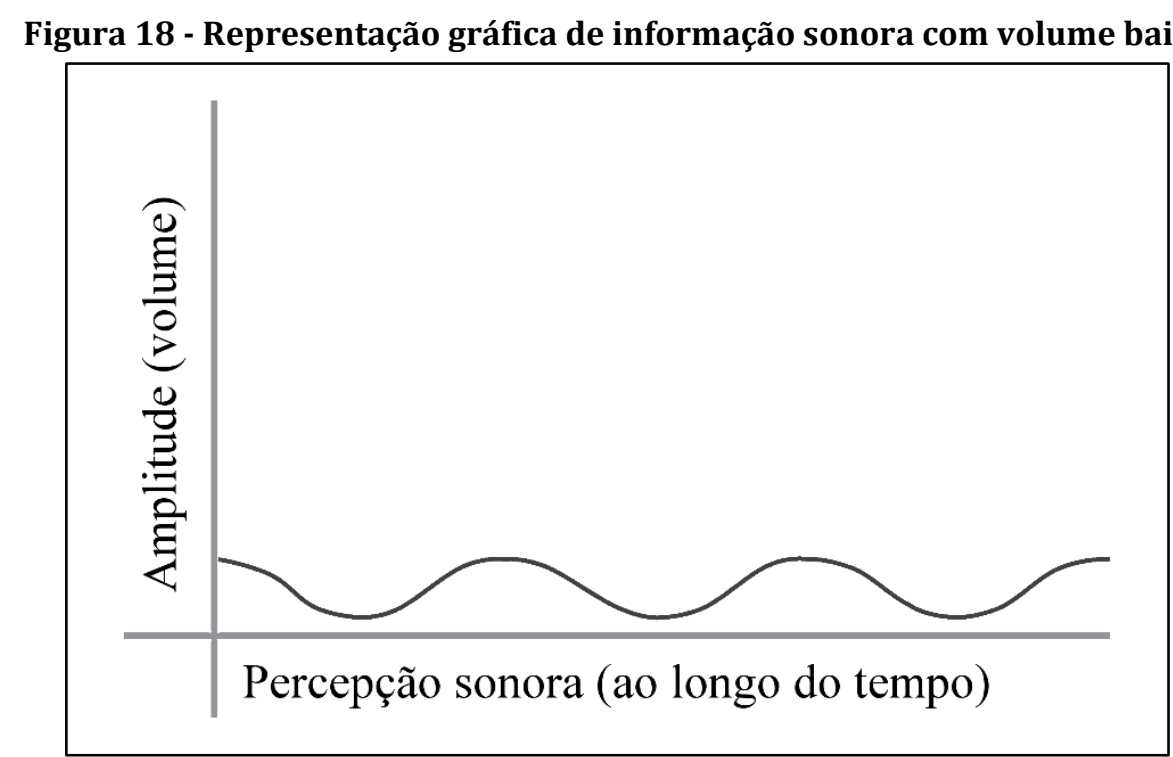

Fonte: do autor (2017)

A percepção auditiva da pessoa que está ouvindo ambos os sons, correspondentes ao ruído com volume alto e à informação com volume baixo, é uma somatória que pode ser representada como na figura 19:

Figura 19 - Representação gráfica de informação sonora com um ruído de volume alto

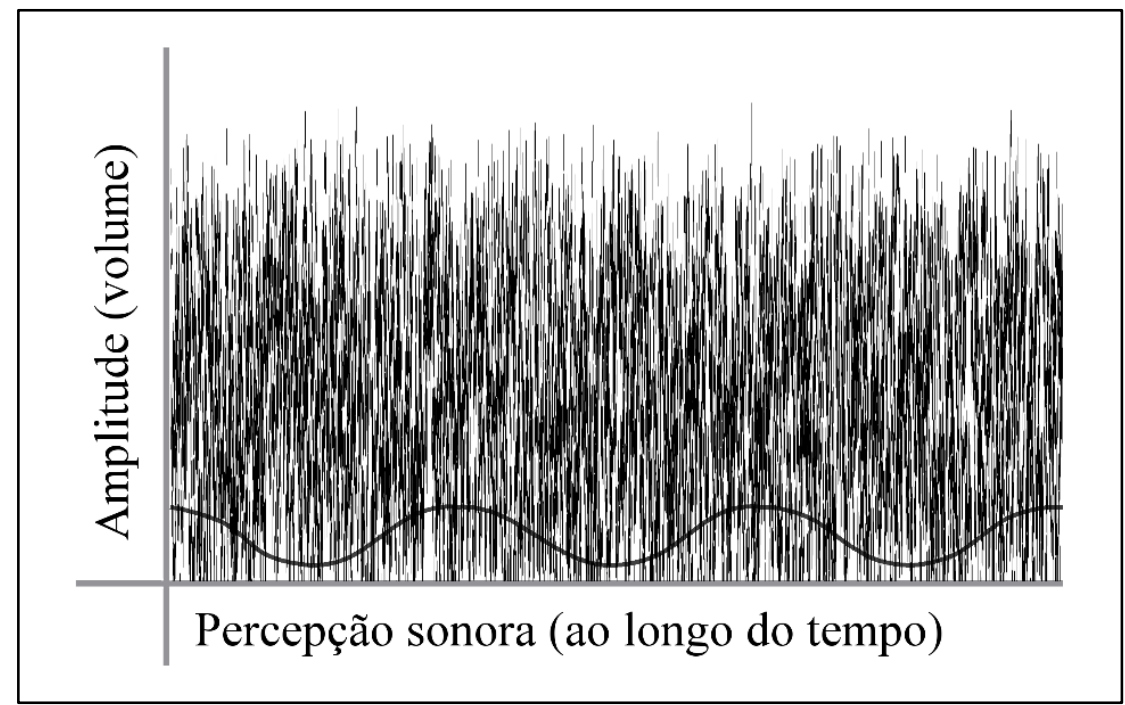

Fonte: do autor (2017) 
Na esfera da percepção auditiva da informação, o ruído pode ter representação em diversas fontes sonoras, não somente no ruído citado pela física. Uma música ambiente, uma propaganda comercial ou uma conversa entre duas pessoas próximas pode não ser uma informação importante para o usuário, e podem ser considerados ruídos à informação útil. 0 comportamento cognitivo da percepção auditiva ante a estes ruídos é semelhante ao ruído físico do chiado auditivo, e podem gerar interferências à compreensão da informação útil caso seu volume sonoro seja sobreposto a estes ruídos.

Nota-se na figura 19, página 92, que a informação auditiva útil ainda está presente, mas é quase completamente ofuscada pelo ruído. Este exemplo de ruído sonoro ressaltando sobre a informação sonora na percepção auditiva é análoga à pregnância da forma na Gestalt, quando a percepção visual do fundo prevalece sobre a percepção visual da forma.

A língua escrita e a língua vocal são os sistemas de informação com maior similaridade entre seus elementos gráficos e auditivos. A língua escrita faz uso de símbolos gráficos organizados em construções verbais que seguem regras gramaticais em formatos sintáticos, semelhante na língua vocal, onde frequências sonoras e tons são organizados em construções verbais que seguem regras gramaticais em formatos sintáticos, formando a linguagem falada.

Além das regras gramaticais necessárias para o estabelecimento da comunicação, a Gestalt também considera a pregnância da forma como elemento fundamental para a compreensão na língua escrita (GOMES FILHO, 2008), assemelhando-se à necessidade de clareza e realce como elementos fundamentais no emprego das frequências sonoras e dos tons para que a língua falada possa ser compreendida.

A analogia entre o visual e o sonoro também pode ser encontrada em características físicas da imagem e do som. As características físicas primordiais das imagens envolvem cor e textura. A cor é formada por componentes que definem como ela será percebida pelos olhos, que são matiz, saturação, brilho e transparência (BUENO, 2010). Toda imagem possui cor e textura, mesmo que não possua outras características associadas às formas, como plano, ritmo, equilíbrio, enquadramento, hierarquia, etc. Ao considerarem-se somente as características 
físicas primordiais da imagem, podem-se associa-las à frequência, timbre e amplitude do som, possibilitando a obtenção de mais uma analogia entre eles: a capacidade de fornecer informações por meio da diferenciação entre cores e sons, recursos estes amplamente utilizados nas sinalizações de informação: placas de aviso que indicam situações de risco e perigo utilizam cores predominantemente vermelhas e amarelas, enquanto que placas com conteúdo predominantemente informativo utilizam cores entre o verde e o azul.

De acordo com Soares (2009, p. 2), a experiência coletiva direciona o significado universal das cores, possibilitando a exploração das cores para finalidades funcionais, psicológicas, medicinais e para organizar a circulação de pessoas e veículos em locais públicos ao se aplicar cores no design de informação.

A associação das cores com informações pré-estabelecidas depende da convergência de processos intuitivos e educacionais com convenções culturais, ou seja, pode estar relacionado também com local e época, o que direciona a compreensão dos usuários das sinalizações cromáticas, oferecendo o potencial de determinar as ações automáticas e instantâneas dos indivíduos. Um exemplo é o uso das cores em sinalizações luminosas semafóricas, que, de acordo com WATANABE (2009) e SOARES (2009, p. 3) adota uma convenção internacional de cores, representada no quadro 9.

Quadro 9 - Convenção internacional de cores para o trânsito

\begin{tabular}{ll}
\hline Cor & Significado \\
\hline Vermelho & Alarme, perigo. \\
\hline Amarelo & Atenção. \\
\hline Azul & Informação. \\
\hline Verde & Ação segura. \\
\hline & Fonte: Watanabe (2009) e Soares (2009)
\end{tabular}

Fonte: Watanabe (2009) e Soares (2009)

Nota-se que a tonalidade das cores de sinalização não é restritiva, admitindo-se variações dentro de cada domínio de cor.

Devido à padronização de cores na sinalização de trânsito que motoristas do mundo, todo cessam o movimento de seus veículos ao se depararem com um semáforo com aspecto vermelho aceso. 
Analogamente, quando se deseja indicar perigo ou risco por meio de som, são utilizadas frequências mais altas, que formam sons agudos, como os encontrados em sirenes de ambulâncias, viaturas policiais, avisos de entrada e saída de veículos, alarmes de incêndio e outros alertas e alarmes, não se encontrando sons graves, de baixa frequência, para estes casos.

Watanabe (2009) cita também o uso da neurolinguística para a escolha das cores verde e azul em indicações de direção e localização, respectivamente. Por este motivo a cor verde, que representa permissão, é utilizada em placas de trânsito de direcionamento, simbolizando uma "permissão para seguir". Todas as placas verdes possuem setas indicativas de qual direção seguir, conforme mostrado nos exemplos da figura 20.

Figura 20 - Exemplos de placas verdes para indicação de direção pelo mundo

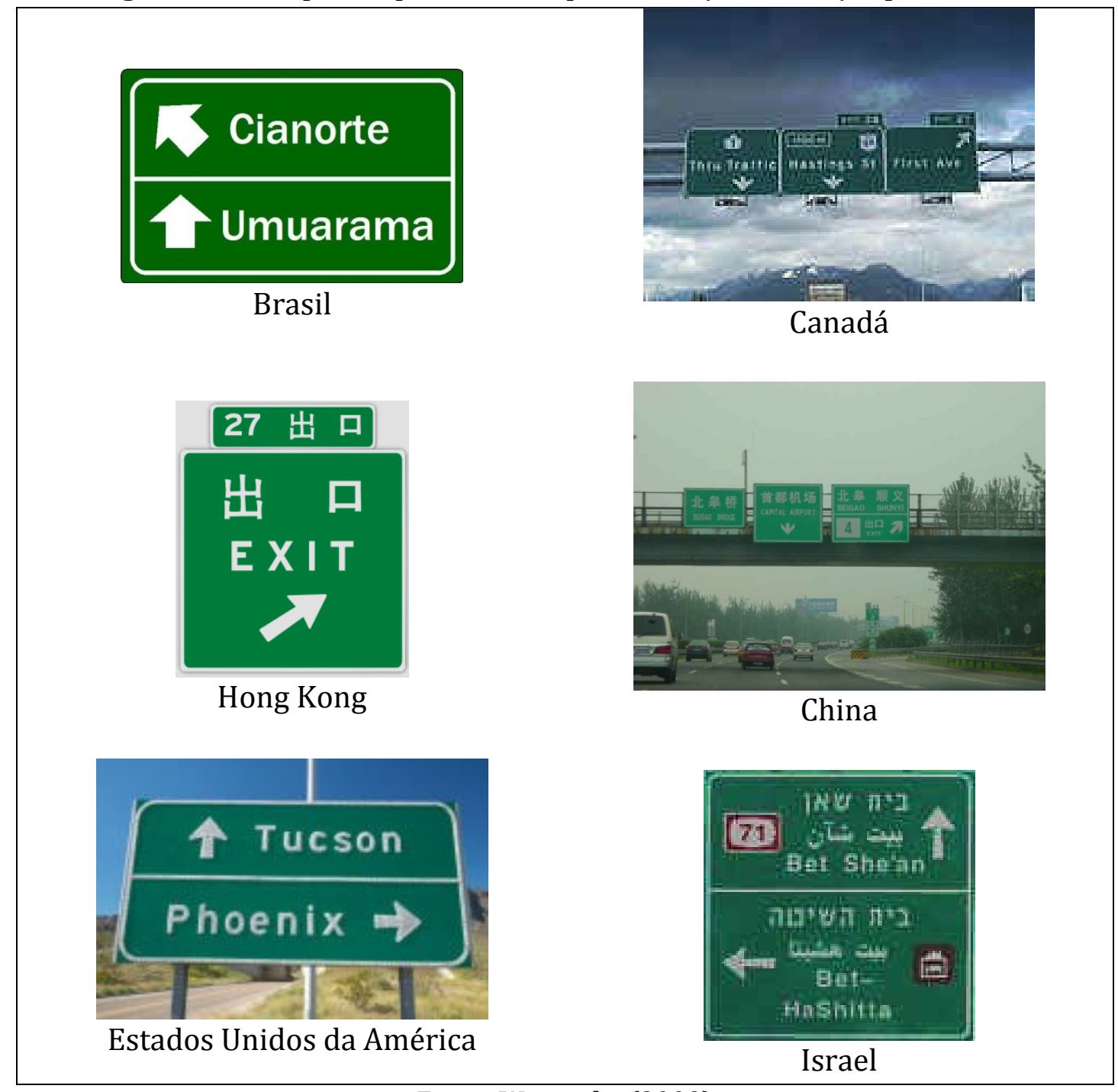

Fonte: Watanabe (2009) 
Da mesma forma, sendo a cor azul a adotada para informação, placas de cor azul são utilizadas internacionalmente para indicar localizações (WATANABE, 2009). Assim, placas com nomes de rua, indicações de locais de descanso, de restaurantes e de postos de combustível nas estradas possuem cor azul, conforme mostrado nos exemplos da figura 21.

Figura 21 - Exemplos de placas azuis de indicação de lugares

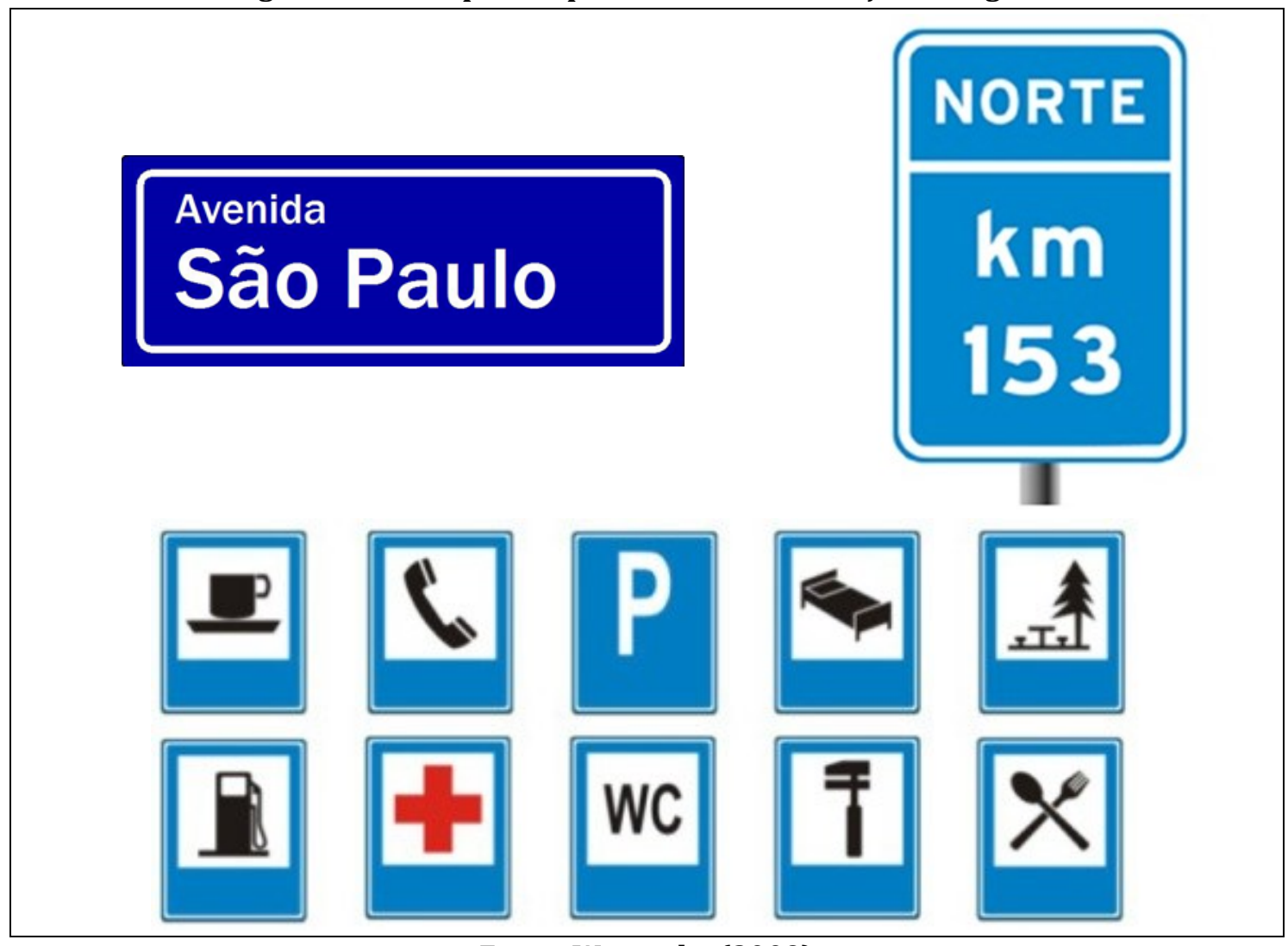

Fonte: Watanabe (2009)

Assim, as cores podem ser utilizadas como um indicador que facilita a identificação do tipo de informação que ela contém. 0 mesmo princípio pode ser utilizado com informações por áudio: para fornecer uma mensagem verbal, o designer pode precedê-la com um formato de áudio que funcione como contraste para o som ambiente e como contextualização do conteúdo que virá em seguida. Este formato de informação audível é amplamente utilizado em informações direcionadas a ambientes públicos, como locuções em aeroportos, estações e trens urbanos e shopping centers, quando determinada mensagem verbal é precedida de um pequeno conjunto de tons harmônicos para chamar a atenção das pessoas à informação que virá a seguir. 
Analogamente, os elementos sonoros podem ser organizados em estruturas que evidenciam o conjunto. Um exemplo de estrutura sonora é a música. De acordo com Sacks (2007), ouvir música não é um processo passivo, pois a música provoca uma interrupção nos processos da atenção, concordando com Norman (2006). Sacks cita que a atenção dispendida à música ocorre de forma automática, independentemente se a pessoa está ouvindo de modo consciente ou inconsciente, e os processos cognitivos voltam-se ao processamento da estrutura musical de forma tão intensa que as nuances das notas e da construção da música são compreendidas de forma tão rápida e precisa que bastam alguns compassos para tornar possível a previsão da estrutura musical que virá em seguida.

A estrutura musical é uma forma de organizar as notas musicais, promovendo uma linguagem harmônica que irradia uma sensação de continuidade por meio de uma sucessão de sons, chamada melodia, no objetivo de formar um sentido musical (DANTAS, 2003, p. 18). Segundo Dantas (2003, p. 20), as notas musicais são frequências sonoras que possuem quatro propriedades: altura, duração, intensidade e timbre. Cada instrumento musical gera frequências sonoras que se diferenciam pela combinação destas quatro características, tornando possível sua identificação pelo sentido da audição.

Um conceito musical que faz parte da melodia é a tonalidade. Este conceito é aplicado à música, fazendo com que a melodia siga a frequência e a intensidade de determinadas notas, fomentando um equilíbrio nas relações entre as notas musicais (DANTAS, 2003, p. 47). A tonalidade mantém a harmonia da melodia, delimitando a faixa de frequências que farão parte da música, mas pode ser modificada ao longo da música, criando uma variação na melodia.

Estes conceitos de estrutura musical podem ser organizados hierarquicamente para facilitar a compreensão da importância de cada componente musical. Esta organização pode ser representada como na figura 22, página 98. 
Figura 22 - Hierarquia dos componentes sonoros na música

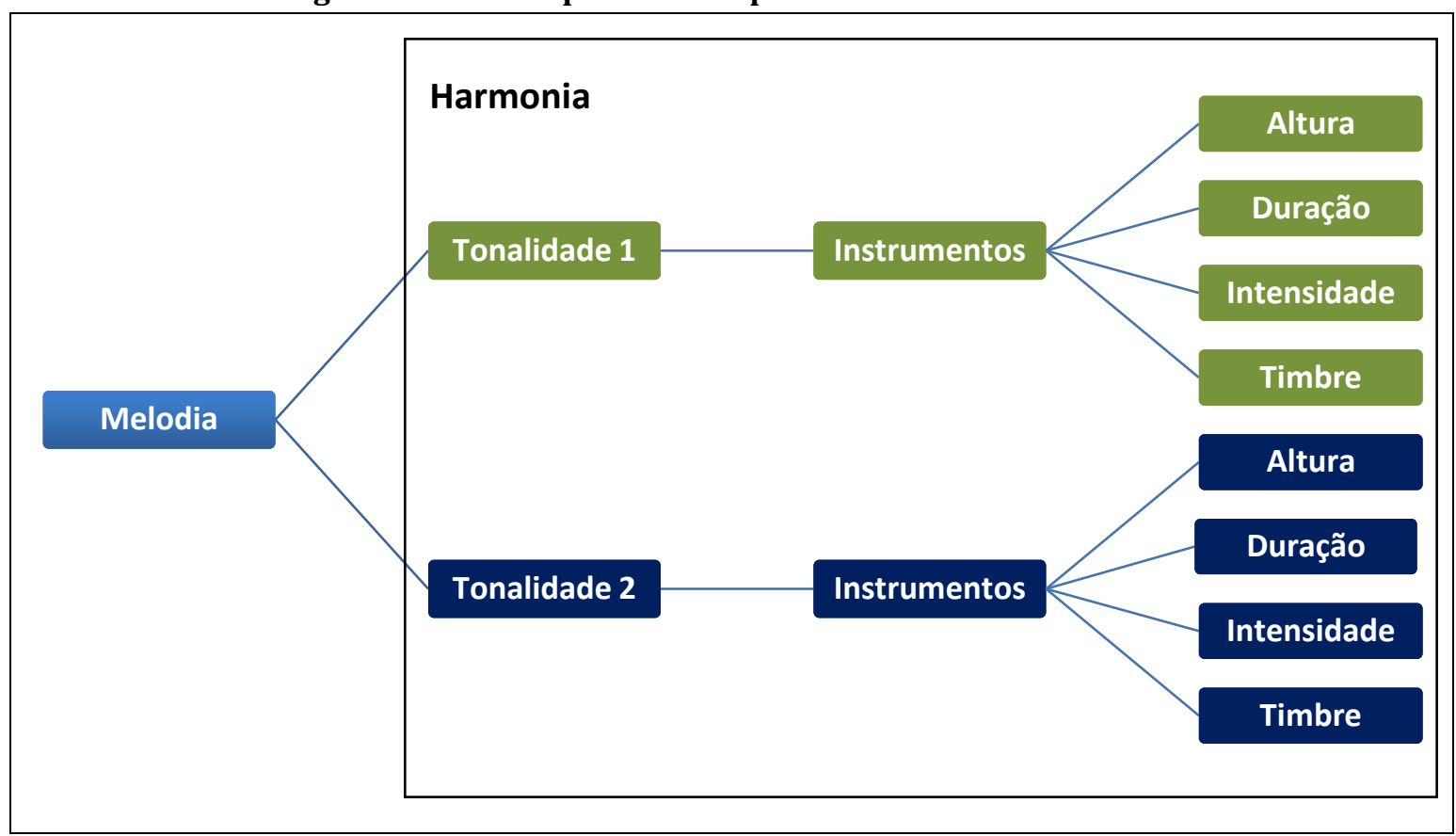

Fonte: o autor, com base em Dantas (2003)

Apesar de exemplificadas duas tonalidades, sua quantidade pode variar ao longo do tempo, conforme a autoria da música.

A figura 22 demonstra que a melodia é o resultado do conjunto das tonalidades, formando uma organização sintática que determina a harmonia da música, ou seja, é a linguagem musical que o compositor criou. Sendo uma linguagem, os processos cognitivos trabalham para reconhecer padrões linguísticos, mesmo que não verbais, possibilitando até mesmo a identificação de uma melodia conhecida, mesmo quando esta melodia está inserida em uma música diferente da originalmente conhecida pela pessoa. Este modo de reconhecimento possibilita ao cérebro humano uma compreensão geral da forma da melodia, semelhantemente à pregnância da forma.

A semelhança entre a estrutura da imagem e a estrutura musical possibilita a transposição aproximada das leis da Gestalt para os elementos sonoros. 0 quadro 10 na página 99 demonstra esta possível analogia. 
Quadro 10 - Analogia das características visual x sonoro

\begin{tabular}{|c|c|c|}
\hline Regras da Gestalt & Elementos visuais & Elementos sonoros \\
\hline $\begin{array}{l}\text { - Segregação; } \\
\text { - Unidade. }\end{array}$ & $\begin{array}{l}\text { - Objeto único ou parte de } \\
\text { um todo. }\end{array}$ & $\begin{array}{l}\text { - Tonalidade; } \\
\text { • Nota musical. }\end{array}$ \\
\hline $\begin{array}{l}\text { - Unificação; } \\
\text { - Fechamento. }\end{array}$ & - Objeto consubstanciado. & • Harmonia. \\
\hline $\begin{array}{l}\text { - Continuação; } \\
\text { - Semelhança. }\end{array}$ & - Similaridade. & $\begin{array}{l}\text { - Tonalidade; } \\
\text { - Melodia; } \\
\text { - Harmonia. }\end{array}$ \\
\hline $\begin{array}{l}\text { - Proximidade; } \\
\text { - Semelhança. }\end{array}$ & - Familiaridade. & $\begin{array}{l}\text { - Frequência; } \\
\text { - Melodia. }\end{array}$ \\
\hline $\begin{array}{l}\text { - Compreensão da } \\
\text { língua. }\end{array}$ & $\begin{array}{l}\text { - Organização sintática de } \\
\text { símbolos gráficos; } \\
\text { - Pregnância da forma. }\end{array}$ & $\begin{array}{l}\text { - Organização sintática de } \\
\text { frequências sonoras e } \\
\text { tonalidades; } \\
\text { - Clareza, realce. }\end{array}$ \\
\hline
\end{tabular}

Fonte: do autor (2016)

Assim como é possível identificar algumas qualidades da Gestalt para os sons, por meio do estudo das frequências e notas, tonalidades, melodia e harmonia, pode-se utilizar o som para transmitir a uma pessoa, mesmo que de forma menos apurada que a visual, algumas sensações relacionadas a características físicas da linguagem visual, como as sensações simbolizadas por cores ou texturas de superfícies, compondo uma linguagem de sinalização sonora que busque a clareza da informação por meio da organização sintática de frequências ou notas musicais, de tonalidades e até mesmo fazendo o uso de harmonias e melodias.

Por fim, a clareza e concisão dos elementos da comunicação levam também aos elementos temporais da informação, relacionados ao momento de informar, ao tempo dispendido para informar e à estabilidade da informação. Redig (2004, p. 65) cita a necessidade de prudência do designer de informação para fornecer uma comunicação atualizada no momento em que ela é necessária, em velocidade suficiente para que o receptor decifre toda a informação, tornando-a útil para sua tomada de decisão. 
Os preceitos obtidos com os pressupostos da analogia entre os conceitos visuais e auditivos podem ser aplicados à elaboração de interfaces eletrônicas para o uso de pessoas com deficiência visual, as chamadas ajudas eletrônicas (FELIPPE, 2001, p. $10)$.

\subsection{ORIENTAÇÃO POR AJUDAS ELETRÔNICAS}

0 acesso aos dispositivos eletrônicos portáteis inteligentes pode ser uma das soluções que proporcione maior liberdade e autonomia para a navegação de pessoas com deficiência visual, mas, para que isto ocorra, é necessário que o projetista da interface minimize e até mesmo elimine as complexidades destes aparelhos por meio do conhecimento sobre as peculiaridades inerentes à deficiência visual, possibilitando uma interação segura e autônoma também na interface, tanto no campo da sintática de comandos e indicações como no campo da semântica sobre a compreensão das informações fornecidas pela interface. Segundo Galitz (2007, p. XIX), para que o uso da interface seja eficiente, o bom design precisa englobar fatores relacionados aos processos cognitivos, buscando relações sobre as formas com que as pessoas compreendem, sentem e pensam sobre a interface, e isto inclui o formato que a informação precisa ter para melhor aceitação e a compreensão do usuário.

A interface é a parte do sistema que o usuário tem contato, é o meio pelo qual ele interage para realizar tarefas (KULPA, 2009, p. 22) e pode conter diversos elementos de interação com o usuário, entre elas imagem, forma, sons e sinais hápticos. De acordo com Bonsiepe (1997, p. 59), a função da interface é "permitir ao usuário obter uma visão panorâmica do conteúdo, navegar na massa de dados sem perder a orientação e, por fim, mover-se no espaço informacional de acordo com seus interesses".

Para Carvalho (1994, p. 21), as interfaces de computadores são como a embalagem do produto: quando os sistemas possuem interfaces bem projetadas, fomentam sentimentos positivos de sucesso e competência no usuário, pois as interfaces que não trazem dificuldades na sua operação permitem que o usuário se concentre no trabalho que precisa realizar, e não na resolução de falhas que, muitas vezes, não são de seu domínio. É importante observar que a interface representa significados 
comuns, espelhados no comportamento de objetos disponibilizados ao usuário, tornando-se uma ponte entre sua compreensão e a atividade a ser executada. 0 conhecimento técnico de como o sistema executa determinadas tarefas, muitas vezes não é conhecida pelo usuário. Então, a utilização de uma linguagem metafórica por meio de um contexto comum entre o usuário e o sistema, menos técnica e mais humana, torna a compreensão da tarefa mais fácil de ser atingida (ROCHA e BARANAUSKAS, 2003, p. 12).

Outro conceito que deve ser reforçado é que o projeto de interfaces humanocomputador deve ser pautado nos princípios do design universal, permitindo que esta interface seja utilizada por pessoas com habilidades diversas. Isso significa que não se deve atribuir peso demais a uma determinada habilidade, privilegiando uma competência em detrimento de outras (BARANAUSKAS, HORNUNG e MARTINS, 2008). No entanto, deve ser dispendido um trabalho cuidadoso para o design universal, pois a necessidade de integrar diversas funções que universalizam a interface não deve ser justificativa para o design complexo e confuso, posto que o aumento do número de opções e capacidades de qualquer aparelho pode significar também um aumento no número e na complexidade de seus controles. Os princípios do bom design podem ser aplicados para tornar esta complexidade controlável e fácil de lidar (NORMAN, 2006, p. 55).

Para possibilitar que o uso de equipamentos eletrônicos auxilie as pessoas com deficiência visual a navegarem em ambientes públicos, se faz necessário um método de descrever o trajeto da pessoa. Um modelo similar conhecido são os aparelhos de navegação por GPS, que fornecem indicações audiovisuais acerca do trajeto programado pelo usuário, informando a este, em tempo real, as direções que precisam ser seguidas ao longo do trajeto. No entanto, segundo Quaresma e Moraes (2008, p. 2), ao utilizarem o navegador GPS, os usuários habituais possuem a opção de olharem a tela do aparelho em caso de dúvidas quanto às informações de áudio, e esta opção não é viável para pessoas com deficiência visual.

As tecnologias de equipamentos eletrônicos projetadas para facilitar a identificação de obstáculos no processo de orientação e mobilidade são chamadas de ajudas eletrônicas (GIACOMINI, 2008, p. 22). De acordo com Harper (HARPER, 
1998, p. 23), desde 1897 existem pesquisas e o desenvolvimento de tecnologias assistivas para pessoas com deficiência visual com base em aparelhos elétricos, e as pesquisas com aparelhos eletrônicos portáteis para a autonomia no deslocamento de pessoas com deficiência visual advém da década de 1950.

A navegação por reconhecimento de elementos distantes depende primeiramente de pontos de referência visuais: esquinas, edificações, placas, etc. Algumas referências distantes podem ser percebidas a distância pelo sentido da audição: barulhos de automóveis, alarmes, buzinas, etc. Nenhuma referência à distância pode ser percebida pelo tato, somente referências próximas, ao alcance da pessoa. As pessoas com deficiência visual têm dificuldades de percepção de pontos de referência visuais, dependendo da profundidade de sua deficiência. Desta forma é comum utilizarem-se da navegação cinestésica, do conhecimento prévio do trajeto a ser seguido e de alguns pontos de referência táteis e sonoros para confirmação e ajustes de rota (LOOMIS, KLATSKY e GOLLEDGE, 2001, p. 283).

Com a popularização dos smartphones ${ }^{7}$, as pessoas com deficiência visual também têm se utilizado destes pequenos computadores em seu dia-a-dia, inclusive da navegação por GPS, buscando incrementar a autonomia no processo de caminharem em áreas públicas ao ar livre (LOOMIS, KLATSKY e GOLLEDGE, 2001, p. 286). No entanto, de acordo com Treuille et al. (2007), Mariani (2016) e Loomis et al. (2001), as interfaces atuais dos GPSs não são adequadas para pessoas com deficiência visual, parte devido às características intrínsecas ao sistema, que tem uma imprecisão de posicionamento da ordem de 10 metros no mínimo, e parte devido ao amplo emprego de informações gráficas, impossíveis de serem utilizadas por pessoas com deficiência visual.

Com a correta aplicação do design universal, a tecnologia de navegação eletrônica com audiodescrição pode ajudar na missão de fornecer a identificação de pontos de referência distantes, assim como outras informações sobre os ambientes para

\footnotetext{
7 De acordo com Zheng e Ni (2006, p. 2), smartphone é uma categoria de telefones celulares que possui tela colorida, capacidade avançada de rede sem fio, grande capacidade de memória e de processamento, e a presença de um sistema operacional completo que permita a instalação de aplicativos.
} 
usuários com deficiência visual, por meio de tecnologias que possam informar, antecipadamente, as peculiaridades que vão surgindo ao longo do trajeto.

\section{- NAVEGAÇÃO ELETRÔNICA}

O GPS é um sistema que permite identificar, por meio de sinais emitidos por satélites em órbita da Terra, a posição geográfica terrestre exata do aparelho receptor (PARKINSON e ENGE, 1996). Por utilizar satélites em órbita terrestre, somente funciona ao ar livre, tornando sua utilização impossível em ambientes fechados, caso a visada para o céu esteja obstruída, pois a ausência da visada para o céu causa um aumento exponencial no erro de distância de indicação (WELLENHOF, LICHTENEGGER e COLLINS, 2013, p. 152).

Também conforme Wellenhof, Lichtenegger e Collins (2013, p. 6-13), o GPS foi planejado inicialmente com propósitos militares, mas, no início dos anos 2000, os sistemas de navegação por GPS começaram a ser disponibilizados para outras funcionalidades, se tornando populares e de fácil acesso, possibilitando seu uso por civis em diversas aplicações, como por exemplo, para realizar agrimensura ou até mesmo para que profissionais especialistas de diversas áreas de conhecimento possam se localizar em regiões inóspitas do planeta. No entanto, provavelmente a utilização mais notável seja a de auxiliar no deslocamento por ruas e avenidas de cidades, ação conhecida como "navegação por GPS", que faz uso de mapas eletrônicos instalados em pequenos computadores dedicados e, desde meados dos anos 2000, também presente em smartphones.

Os mapas presentes na navegação por GPS oferecem informações para facilitar a navegação com base em pontos de referência, mas também disponibilizam a facilidade de mostrar, com certa antecedência, a próxima mudança de direção no trajeto, livrando a pessoa da necessidade de memorização do mapa. Assim, a pessoa pode simplesmente fornecer o destino ao equipamento e seguir sequencialmente as indicações fornecidas, sem a necessidade de conhecer previamente o trajeto até o destino. A figura 23, na página 104, ilustra um exemplo de mapa mostrado em tela de aplicativo GPS. 


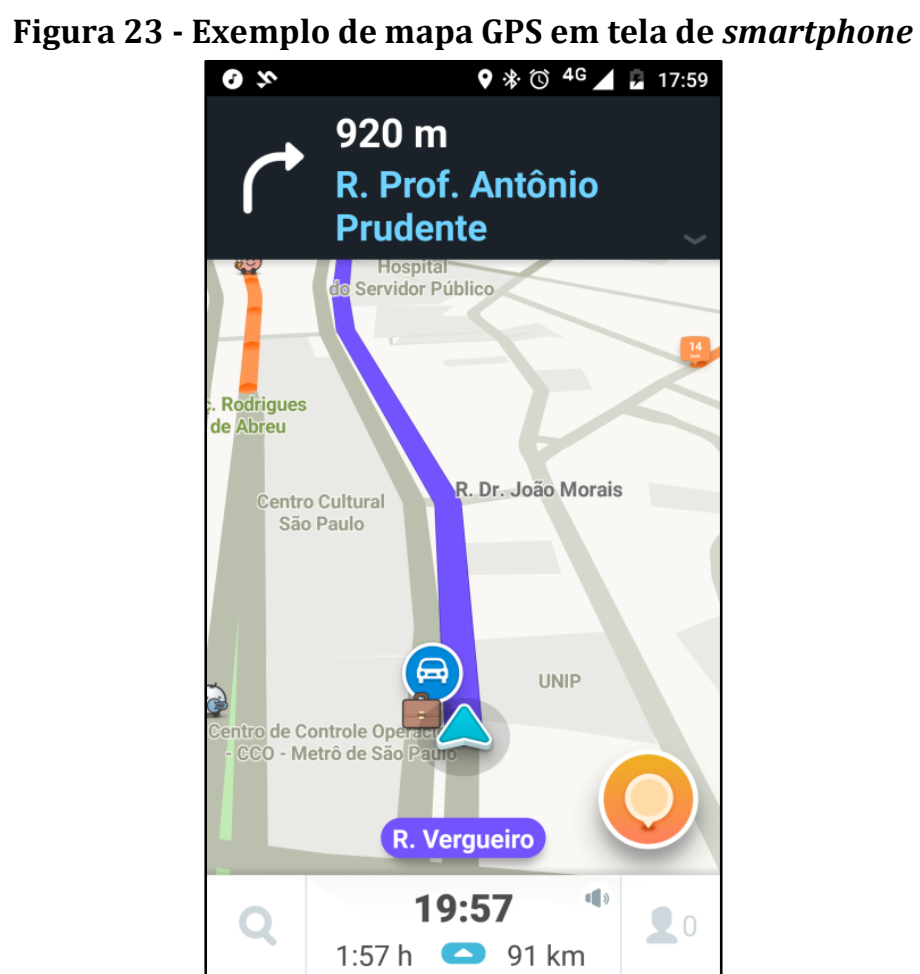

Fonte: tela capturada pelo autor (2016)

Alguns computadores de navegação por GPS utilizam sons simples, sem voz, para guiar o caminho a ser seguido. Os sons não vocais são componentes presentes em diversas interfaces de equipamentos. Sua utilização facilita a comunicação rápida de situações onde não seja necessário alertar para algo, ou quando se deseja o uso de efeitos sonoros (NORMAN, 2006, p. 132-133). Em um primeiro momento, podese pensar que GPSs que empregam este tipo de funcionamento serviriam para o uso de pessoas com deficiência visual, pois independe da existência de um mapa gráfico. No entanto, esta abordagem pode causar confusão, pois os usuários podem não compreender qual informação o sistema está apresentando (QUARESMA e MORAES, 2008). De acordo com Barbosa (2015, p. 476) e Mariani (2016, p. 235) os melhores resultados para guiar pessoas com deficiência visual em espaços públicos seriam obtidos por meio do uso de aparelhos que empregam formas de audiodescrição para descrever os pontos de referência ao longo do trajeto a ser seguido, complementando assim a capacidade da navegação cinestésica. 


\section{- AUDIODESCRIÇÃO}

De acordo com Franco e Silva (2010, p. 24) não existe registro de quando se iniciou a prática de descrever o mundo visual para pessoas com deficiência visual, mas a atividade técnica e profissional de executar esta tarefa iniciou-se em 1975, nos Estados Unidos, e é chamada "audiodescrição", frequentemente citada com a sigla de “AD”.

O uso da eletrônica para facilitar a audiodescrição iniciou-se em 1982, pelo casal Margareth e Cody Pfanstiehl, que disponibilizaram a audiodescrição do programa de Televisão (TV) American Playhouse. Enquanto a série era transmitida pela Public Broadcasting Service (PBS), a audiodescrição era transmitida simultaneamente via rádio (FRANCO e SILVA, 2010, p. 24).

No Brasil, a audiodescrição de eventos culturais com peças teatrais, programas de TV e cinemas é um direito garantido pela lei 10.098 (BRASIL, 19. dez. 2000) e regulamentada pelo Decreto 5.296 (BRASIL, 2 dez. 2004), mas, de acordo com Franco e Silva (2010, p. 33), a aplicação em definitivo da lei vem sofrendo seguidas concessões de descumprimento pelos meios de comunicação por meio de portarias, enquanto a continuidade das pesquisas e uso da audiodescrição vem aumentando por conta do interesse da iniciativa privada em disponibilizar seu conteúdo para pessoas com deficiência visual.

A audiodescrição depende de diversos fatores sintáticos e semânticos relacionados ao tipo de conteúdo a ser disponibilizado, modificando tanto a forma de se descrever o assunto quanto ao planejamento da forma do usuário compreendê-las. Além disso, a audiodescrição é um produto que descreve outros produtos para o usuário com deficiência visual. Assim, o estudo necessário para a elaboração da audiodescrição precisa assimilar três conceitos inter-relacionados: as peculiaridades do usuário, os produtos a serem descritos e as características disponíveis para a elaboração da audiodescrição. Segundo Dantas (2005, p. 227), o estudo da relação entre o usuário e os objetos é o foco da pesquisa para o desenvolvimento de produtos, exigindo que o designer se integre no cotidiano do usuário, de modo intuitivo e não-reflexivo, obtendo-se maior objetividade por meio da percepção dos anseios do usuário e da minimização dos próprios 
preconceitos do designer. Estes preceitos precisam ser ainda mais reforçados quando o desenvolvimento do produto envolve usuários cuja percepção da realidade é muito diferente do usual, como as pessoas com deficiência visual, das quais o mundo é um conjunto de sensações sonoras, táteis, olfativas e gustativas.

Enquanto a audiodescrição de programas de televisão e de imagens na tela de computadores apresentam informações diretas ao usuário, que se referem à imagem que está sendo apresentada na tela, a audiodescrição de um caminho em um aparelho de GPS refere-se a uma ação relativa ao trajeto que a pessoa precisa seguir, independentemente se a pessoa está na direção de um veículo ou se está cumprindo o trajeto a pé. Para que o trajeto seja seguido corretamente, a informação precisa ser legível e completa. Por outro lado, como a pessoa está em movimento, esta informação também precisa ser transmitida de forma rápida, dentro de limites de tempo que permitam à pessoa realizar as mudanças de direção para continuarem no trajeto correto (QUARESMA e MORAES, 2008, p. 2).

Da mesma forma, pode-se diferenciar a audiodescrição da tela de TV com a tela de computadores. Mesmo possuindo características aparentemente semelhantes, de conteúdo visual, o ato de assistir a filmes e programas de televisão são fundamentalmente diferentes de utilizar de telas em computadores com Graphical User Interface - GUI (HEWETT, BAECKER, et al., 1992; MBURU, 2013), ou interface gráfica para o usuário (tradução livre pelo autor). Ambas as audiodescrições fornecem informações sobre o conteúdo visual das telas, por meio de voz digital. No entanto, a utilização de audiodescrição em computadores difere da audiodescrição de filmes e programas de televisão, pois na GUI o usuário não é simplesmente um espectador, ele interage com o computador, fornecendo comandos e informações para que a máquina processe. Assim, para este tipo específico de audionavegação, surgiram os leitores de tela, que são aplicativos que transformam as informações gráficas em voz.

De acordo com Carvalho e Aranha (1998), até o final da década de 1990 as aplicações que funcionam em ambiente GUI eram muito difíceis de serem adaptadas aos leitores de tela. No entanto, de acordo com Neto et al. (2005), a tecnologia mais atual de processamento de fala encontra-se bastante avançada, o 
atual nível de desenvolvimento dos softwares sintetizadores de voz já permite a utilização de ambientes gráficos em praticamente toda sua plenitude. Inicialmente utilizado para ler exclusivamente os textos presentes na tela do computador, hoje os softwares de voz sintética podem realizar a audiodescrição de praticamente todo o conteúdo que está sendo apresentado para o usuário, seja texto ou gráfico.

Duas tecnologias de interface de voz referem-se à interação de mão dupla necessária para a utilização de computadores por meio da voz: a Automatic Speech Recognition $\left(A S R^{8}\right)$, que é a tecnologia responsável pelo envio de comandos de voz para o computador; e a Text-to-speech $\left(T T S^{9}\right)$, que é a tecnologia responsável pela transformação das respostas do computador em voz sintetizada para o usuário (NETO, SOUZA, et al., 2005).

0 uso de tecnologias ASR demanda maior poder de processamento dos computadores, comparando-a às tecnologias TTS, e por isso a ASR era inviável antes da década de 1980, quando surgiram as primeiras tecnologias de TTS. Ainda hoje, para que seja possível o reconhecimento de voz para comandos $A S R$, muitas vezes se faz necessário estar conectado à internet, para que a fala humana possa ser processada por computadores com maior capacidade de cálculo, em uma forma de processamento compartilhado conhecido como computação em nuvem ${ }^{10}$.

Dois exemplos desta forma de processamento são utilizados pela Apple e seu software Siri ${ }^{11}$, e pela Google ${ }^{12}$ e seu software Google Voice Search ${ }^{13}$. Ambos os exemplos são amplamente utilizados em smartphones, no objetivo de permitir que

\footnotetext{
8 Reconhecimento Automático de Fala (tradução pelo autor).

9 Texto a ser dito (tradução pelo autor).

10 De acordo com Ruschel, Zanotto e Mota (2010), a computação em nuvem é a ideia de se utilizar, em qualquer lugar e independente de plataforma, os mais variados tipos de aplicações, por meio da internet, com a mesma facilidade de tê-las instaladas nos computadores do usuário. Com isso, a capacidade de supercomputadores colocados em centros de processamento pode ser utilizada pelas pessoas de forma remota, pois tudo será baseado na internet.

11 Speech Interpretation and Recognition Interface, ou "Interface de Interpretação e Reconhecimento de Fala" (tradução pelo autor).

12 Google Inc. é uma empresa norte-americana de software e serviços de tecnologia da informação.

13 Busca por voz do Google (tradução pelo autor).
} 
o usuário forneça instruções por voz sem que seja necessário disponibilizar recursos de processamento pesado no smartphone (BRITO, STRAUSS e MELLO, 2012).

Diferente da $A S R$, as tecnologias TTS demandam de menor poder computacional. No entanto, isso não significa obrigatoriamente que são tecnologias simples. No final da década de 1980 já existiam softwares que permitiam a computadores pessoais gerarem voz. No entanto, as vozes geradas pelos computadores daquela época eram vozes "robóticas", pois simplesmente se dedicavam a transformar sílabas em som. Ainda hoje, mesmo sendo as atuais capacidades de processamento computacionais muito superiores às disponíveis no final da década de 1980, o principal desafio dos desenvolvedores é fazer com que a voz sintetizada se pareça com a voz natural humana, por meio da evolução de técnicas eletrônicas de modelagem da prosódia ${ }^{14}$ e da ortoépia ${ }^{15}$, para que a voz sintetizada consiga reproduzir o ritmo e a emoção que um ser humano empregaria em uma fala natural (NETO, SOUZA, et al., 2005).

A adoção de sistemas eletrônicos com recursos de voz sintetizada por audiodescrição e com reconhecimento de voz tem se tornado cada vez mais numerosos, mesmo para sistemas cujo desenvolvimento não é especificamente voltado a pessoas com deficiência visual. Provavelmente o recurso com maior número de usuários e que utilize sintetização de voz sejam os softwares para guiar as pessoas por GPS, onde o mapa é apresentado na tela do computador enquanto uma voz sintetizada vai informando o caminho a ser percorrido em tempo real, permitindo ao usuário, normalmente um condutor de veículo, seguir a audiodescrição do trajeto, desviando o olhar para a tela do computador somente em situações de dúvidas.

\footnotetext{
14 De acordo com Rodrigues e Figueiredo (2010), prosódias são segmentos da fala que contém fenômenos das línguas naturais que abarcam os parâmetros de altura, intensidade, duração, pausa, velocidade, tom, entoação, acento e ritmo.

15 De acordo com Cipro Neto e Infante (1998, p. 25), ortoepia ou ortoépia é uma área da fonoaudiologia que estuda a correta produção oral das palavras.
} 
Existem dois tipos de frases que podem ser utilizadas para gerar informações a serem utilizadas na audiodescrição para a navegação de ambientes: informações com frases imperativas e informações com frases declarativas.

As informações com frases imperativas produzem uma conotação de sugestão ou ordem, fomentando uma ação imediata do usuário. Por este motivo as informações de navegação e orientação são predominantemente imperativas, ao comporem-se de instruções que vão sendo disponibilizadas no momento em que existe a demanda pela realização de determinada tarefa. No escopo de guia e navegação por voz, as informações imperativas podem ser subdivididas em dois tipos intermediários:

- Informações imperativas absolutas de orientação e navegação: são aquelas que indicam uma situação direta, que pode ser percebida e executada sem a necessidade de outras informações. Por exemplo, "vire à direita" é uma informação vocal que pode ser executada no exato momento em que é recebida, pois não precisa de outras informações para ser executada.

- Informações imperativas relativas de orientação e navegação: são aquelas cuja indicação demanda da relação com outras informações de conhecimento prévio. Por exemplo, para que a pessoa execute a ordem vocal "siga por vinte metros", é necessário que esta pessoa tenha capacidade de mensurar a distância em metros, para que ele possa contar vinte unidades de metro.

As informações imperativas relativas de orientação e navegação são específicas da condição do usuário. Por exemplo, para a realidade de uma pessoa vidente, a ordem "vire no segundo corredor à direita" pode parecer uma informação absoluta, pois basta que a pessoa olhe o caminho e identifique o segundo corredor à direita, antes mesmo de chegar a este corredor. Para uma pessoa com deficiência visual, a ausência da identificação prévia do local está prejudicada, pois é uma informação visual, tornando-a uma informação relativa, devido à necessidade da existência de uma informação prévia sobre a posição de ambos os corredores, tornando possível que a pessoa siga corretamente até o segundo corredor. Esta 
informação prévia pode vir de várias fontes, como, por exemplo, por meio da memorização do ambiente que o usuário porventura esteja familiarizado, ou por outros meios não visuais de se identificar ambos os corredores, como indicações no piso tátil, sensações táteis ao buscar o vão de entrada do corredor com a bengala longa ou as mãos, ou qualquer outra forma que possibilite que o usuário com deficiência visual possa contar os corredores à direita e escolher o segundo.

As informações com frases declarativas não se prestam para guiar a pessoa por um caminho. São informações com conteúdo indicativo. Por exemplo, uma mensagem "porta do elevador aberta" é uma informação exclusivamente indicativa, não existe conotação imperativa que demande de uma ação imediata do usuário. No entanto, a mensagem a ser transmitida pode ser composta de frases declarativas e frases imperativas. Por exemplo, se a mensagem fosse "porta do elevador aberta, entre no elevador", seria uma mensagem que se inicia com um componente declarativo, para informar uma situação, e que termina com um componente imperativo, pois se o usuário quiser continuar seu caminho, ele precisa entrar no elevador.

As pessoas videntes tendem a associar o wayfinding a informações visuais, dado que a linguagem sonora não está normalmente relacionada aos processos cognitivos que percebem a navegação enquanto caminham por um trajeto. No entanto, de acordo com o trabalho de Klatzky et al. (2006, p. 224), o uso de sons, especificamente sons eletrônicos, tem se mostrado surpreendentemente mais eficiente para a navegação, quando comparado ao uso de informações visuais. Este conceito leva à necessidade de compreender as características do wayfinding que podem fornecer uma linguagem específica de consolidação entre a audiodescrição e a navegação, estabelecendo um formato de audionavegação que possibilite uma maior autonomia para a orientação e mobilidade de pessoas com deficiência visual.

O levantamento bibliográfico possibilitou o refinamento dos saberes acerca de produtos e recursos que possam ser utilizados para prover autonomia na orientação e mobilidade de pessoas com deficiência visual. A primeira parte deste levantamento possibilitou a obtenção de informações sobre os processos cognitivos que atuam sobre as pessoas com cegueira e a baixa visão, relacionando estas informações com as atuais ferramentas que descomplicam o cotidiano dessas 
pessoas. A segunda parte deste levantamento bibliográfico investigou possíveis analogias da percepção humana acerca da física das imagens e dos sons, no domínio do design de informação, buscando-se aspectos do design identificáveis também na informação sonora, culminando na busca por saberes relacionados às tecnologias de mobilidade, orientação e navegação por voz, tanto as atualmente utilizadas por pessoas com deficiência visual como tecnologias regulares mas com potencial de adequação para o design universal. Os conhecimentos adquiridos neste levantamento bibliográfico possibilitaram o planejamento e a execução das pesquisas práticas, por meio da inserção dos conceitos obtidos no domínio dos métodos de pesquisa qualitativa. 



\section{PROCEDIMENTOS METODOLÓGICOS}

A pesquisa prática deste estudo, de natureza exploratória, buscou peculiaridades da possibilidade do uso de audionavegação para orientar a mobilidade de pessoas com deficiência visual em ambientes públicos e transportes de massa. Para este estudo, adotaram-se os princípios da pesquisa qualitativa, de caráter experimental, integrando-se os saberes obtidos nos preceitos teóricos no planejamento da pesquisa prática.

Devido à ausência de formatos de audiodescrição específicos para orientação e mobilidade, constatou-se a necessidade de levantar dados que pudessem ser incorporados a um modelo preliminar de audionavegação, tornando possível a pesquisa prática em ambientes públicos. Estes dados foram obtidos por intermédio de duas pesquisas preliminares, a primeira pesquisa preliminar foi constituída por entrevistas semiestruturadas com a participação de pessoas com deficiência visual para obter conteúdos verbais sobre direcionamento e orientação para a mobilidade, e a segunda pesquisa preliminar consistiu no uso destes conteúdos verbais para orientar voluntários com deficiência visual por audionavegação em um ambiente controlado e privativo. A pesquisa preliminar neste ambiente controlado possibilitou a eliminação de variáveis causadas por situações de imprevisão inerentes a ambientes públicos, no objetivo de encontrar desvios na interface de audionavegação que pudessem ser corrigidos preliminarmente, favorecendo a compilação dos dados que seriam obtidos nos experimentos posteriores, realizados em ambientes públicos.

Nos experimentos práticos em ambientes públicos, denominados experimentos principais, os voluntários com deficiência visual foram acompanhados enquanto orientados pelo aparelho eletrônico com audionavegação para seguirem um trajeto pré-definido, em um percurso envolvendo três ambientes públicos distintos, mas interconectados: o interior de uma estação do Metrô de São Paulo, um trecho de cerca de cento e vinte metros de calçada pública a céu aberto e o interior de uma instituição cultural da cidade de São Paulo, que abriga uma biblioteca planejada para pessoas com deficiência visual. 
Dada à natureza desta pesquisa, de características não biológicas, os voluntários não foram submetidos a riscos, pois o levantamento dos dados da pesquisa foi obtido por meio de entrevistas semiestruturadas e observações participativas, configurando-se como pesquisa de opinião, preservando-se o sigilo das identidades dos voluntários por intermédio da identificação por siglas ao invés de nomes e da descaracterização de rostos em fotografias, tornando este estudo adequado ao artigo $1^{\circ}$ da resolução 510/2016 sobre ética em pesquisa (BRASIL, 2016).

\subsection{PESQUISAS PRELIMINARES}

Por intermédio das informações obtidas nos preceitos teóricos, observou-se a necessidade de um plano de ação gradativo para a pesquisa prática. No objetivo de preparar o experimento principal, no qual os voluntários com deficiência visual se utilizam de aparelho eletrônico com audionavegação para sua orientação em ambientes públicos, foram programadas duas pesquisas preliminares, constituindo-se de entrevistas semiestruturadas e de experimentações prévias do equipamento.

A primeira pesquisa preliminar constituiu-se de entrevistas semiestruturadas, cujo objetivo foi coletar informações essenciais para a elaboração das construções verbais com enfoque em audionavegação, possibilitando a composição das vozes geradas pelo aparelho eletrônico utilizado nas pesquisas subsequentes. Nestas entrevistas buscou-se o entendimento dos voluntários com deficiência visual com relação a construções verbais para orientação e navegação que pudessem ser incorporadas à audionavegação por aparelhos eletrônicos.

Na segunda fase da pesquisa preliminar, as construções verbais obtidas por meio da análise das entrevistas da primeira fase foram incorporadas a uma interface eletrônica a ser utilizada nos testes práticos. Esta interface foi utilizada no interior de uma instituição de apoio a deficientes visuais por pessoas convidadas pela própria instituição. Esta segunda fase das pesquisas preliminares, de caráter qualitativo, teve por objetivo avaliar as peculiaridades cognitivas dos convidados, todos com deficiência visual, enquanto utilizavam a audionavegação para seguir trajetos no interior da instituição. 
A segunda fase da pesquisa preliminar foi realizada em um local fechado e controlado no objetivo de eliminar as interferências inerentes a locais públicos, possibilitando a avaliação isolada das peculiaridades das construções verbais disponibilizadas pela audionavegação. Esta abordagem possibilitou o refinamento das construções verbais obtidas por meio das entrevistas ao avaliá-las em um contexto prático.

\subsubsection{ENTREVISTA COM PESSOAS COM DEFICIÊNCIA VISUAL}

A principal característica da voz sintetizada é a linguagem verbal. Conforme Rogers, Sharp e Preece (2013, p. 83), a linguagem é um processo cognitivo que envolve, além da audição e da fala, outros fatores pessoais como a memória e o aprendizado. Desta forma, para iniciar o estudo, foi necessário colher informações a respeito de linguagens verbais para guiar pessoas, mas com foco na percepção de pessoas com deficiência visual.

Foi elaborado um protocolo de entrevista que realizasse uma coleta de informações que possam compor um modelo de voz sintetizada para guiar pessoas com deficiência visual. Foi escolhida a entrevista padronizada semiestruturada (MARCONI e LAKATOS, 2007, p. 94; LODI, 1998, p. 16; CRESWELL, 2014, p. 116; FLICK, 2009, p. 148), no objetivo de adquirir uma comparação direta entre as respostas por meio da padronização das perguntas.

Para obterem-se voluntários para esta pesquisa, foram contatadas instituições e organizações para pessoas com deficiência visual, e obteve-se uma resposta para colaboração para a pesquisa advinda da Associação para Deficientes Visuais e Amigos (ADEVA), localizada à Rua São Samuel, número 174, no bairro de Vila Mariana, cidade de São Paulo/SP, uma instituição que busca a inclusão de pessoas com deficiência visual na sociedade por meio de cursos de capacitação, educação para o trabalho e reabilitação. Os critérios para a seleção dos convidados tiveram por base os princípios de amostragem intencional elencados por Creswell (2014, p. 128) e Flick (2009, p. 117), selecionando-se convidados para as entrevistas entre pessoas adultas, com liberdade para exercerem sua cidadania, de forma a representarem diferentes características pessoais que fornecessem percepções diferentes, ainda que dentro do domínio da deficiência visual. Também foi pedido 
que os convidados tivessem autonomia em orientação e mobilidade, característica que define a capacidade da pessoa em caminhar autonomamente em locais públicos, pois as pessoas que possuem autonomia podem auxiliar melhor na formação de construções verbais inteligíveis para a audionavegação, pois vivenciam a orientação e mobilidade. Considerou-se pessoas com autonomia aquelas que fazem uso de espaços públicos de forma autônoma em pelo menos três dos cinco dias úteis da semana (de segunda a sexta), buscando-se, desta forma, pessoas que estudam, trabalham ou executam tarefas habituais fora de casa.

As características de diferenciação importantes para selecionar convidados para a entrevista foram relacionadas ao tipo de deficiência, associadas à acuidade visual e ao período da vida o qual o convidado adquiriu a deficiência visual. Foram selecionados voluntários com características diferentes entre os convidados para que se obtenha maior abrangência nas respostas, enriquecendo o conteúdo pretendido:

- Diferenciação de voluntários quanto ao tipo de deficiência visual: possibilita a obtenção de diferenças nos dados sobre a percepção dos ambientes que se relacionem com os diversos graus de deficiência visual, desde a cegueira, que representa a ausência total de percepção de imagens, até a baixa visão, que restringe a acuidade do campo visual, limitando o desempenho da execução de tarefas relacionadas à visão (SILVEIRA, 2010, p. 41). O grau da deficiência não foi mensurado, somente foram classificados em dois grupos, voluntários sem percepção visual dos ambientes e voluntários com alguma percepção visual dos ambientes.

- Diferenciação por período da perda da visão: importante para a compilação das informações que possam sofrer interferências da memória visual latente, posto que uma pessoa com cegueira congênita, ou seja, que nasceu com a deficiência ou a adquiriu antes dos dois anos de idade, não possui memória visual, conforme citado por Mota e Romeu Filho (2010, p. 77).

As características para os voluntários foram apresentadas para a equipe da organização da pesquisa na ADEVA, que convidou seus associados de acordo com o solicitado. As entrevistas foram executadas entre os meses de setembro e outubro 
de 2015. Foi exposta uma introdução para explicar a entrevista, como surgiu sua necessidade e o objetivo pretendido (CRESWELL, 2014, p. 111). Os entrevistados foram convidados a responder às perguntas em uma sala fechada, silenciosa, cedida pela ADEVA. Foram informados que teriam liberdade de tempo para responder a cada uma das questões, assim como para dirimir quaisquer dúvidas sobre cada pergunta antes de responder. Também foram informados que não precisariam responder, caso não soubessem ou não quisessem.

Ainda que esta parte da pesquisa tenha utilizado a entrevista padronizada, foi efetuada de forma semiestruturada, buscando informações de natureza qualitativa, pois seu objetivo foi elaborar modelos verbais que seriam incorporados nos experimentos de campo. Por este motivo os entrevistados indicados pela ADEVA foram chamados sob demanda, por e-mail e telefone, e os convites cessaram no momento em que se observou uma saturação de dados por padrão nas respostas, definindo assim a quantidade de voluntários entrevistados, conforme os preceitos citados por Flick (2009, p. 120).

Os convidados entrevistados foram:

- "RB": sexo masculino. Possui cegueira adquirida após a infância. Sua idade está compreendida entre 40 e 50 anos. Caminha autonomamente em locais públicos utilizando bengala longa. Não possui treinamento formal em orientação e mobilidade, pois é autodidata nesta esfera. Utiliza computador com voz sintetizada. A entrevista foi gravada em áudio, o entrevistado foi informado da gravação.

- "MC": sexo masculino. Possui baixa visão severa, discerne somente luzes e cores. Sua idade está compreendida entre 30 e 40 anos. Caminha autonomamente em locais públicos utilizando bengala longa. Possui treinamento formal em orientação e mobilidade. Não utiliza computador com voz sintetizada. A entrevista foi gravada em áudio, o entrevistado foi informado da gravação.

- "MK": sexo masculino. Possui cegueira congênita. Sua idade está compreendida entre 50 e 60 anos. Caminha autonomamente em locais 
públicos utilizando bengala longa. Possui treinamento formal em orientação e mobilidade. Utiliza computador com voz sintetizada.

- "MI": sexo feminino. Possui baixa visão severa, discerne somente escuro/claro. Sua idade está compreendida entre 30 e 40 anos. Caminha autonomamente em locais públicos utilizando bengala longa. Possui treinamento formal em orientação e mobilidade. Utiliza computador com voz sintetizada.

- "CE": sexo feminino. Possui cegueira congênita. Sua idade está compreendida entre 50 e 60 anos. Caminha autonomamente em locais públicos utilizando bengala longa. Possui treinamento formal em orientação e mobilidade. Utiliza computador com voz sintetizada.

- "SE": sexo masculino. Possui cegueira congênita. Sua idade está compreendida entre 40 e 50 anos. Caminha autonomamente em locais públicos utilizando cão-guia. Possui treinamento formal em orientação e mobilidade. Utiliza computador com voz sintetizada.

Aos convidados que participaram das entrevistas foi oferecido um termo de consentimento livre e esclarecido, enviado por e-mail a pedido deles, pois puderam ler o termo de forma autônoma com seus próprios aparelhos eletrônicos. 0 termo lhes garantiu o anonimato e o conhecimento prévio dos objetivos da entrevista, conforme proposto por Creswell (2014, p. 128). Os modelos dos termos estão no apêndice " $F$ " (página 219) deste trabalho.

Como o objetivo de incorporar as respostas desta entrevista em interfaces vocais, foram elaborados cenários fictícios sobre situações de direcionamento e descrição ambiental. Assim, adotaram-se perguntas para o levantamento de respostas com conteúdo direcional e informativo, com conotação absoluta e relativa, e que resultem em frases imperativas ${ }^{16}$ e frases descritivas objetivas ${ }^{17}$. Também foi solicitado aos entrevistados que formulassem respostas tão curtas e diretas quanto

\footnotetext{
16 Imperativo: quando o verbo indica ordem, pedido ou sugestão (CIPRO NETO e INFANTE, 1998).

$17 \mathrm{Na}$ descrição objetiva (...) o propósito é relatar as características do "objeto" de modo preciso, isentando-se de comentários pessoais ou atribuições de quaisquer termos que possibilitem a múltiplas interpretações (DUARTE, 2016).
} 
possível, pois, de acordo com Rogers, Sharp e Preece, interfaces com respostas sintéticas reduzem a carga da memória (ROGERS, SHARP e PREECE, 2013, p. 72) e da atenção (ROGERS, SHARP e PREECE, 2013, p. 67), facilitando que o usuário possa dispender sua atenção a outras informações ambientais que não provém da interface.

O questionário tomou por base os princípios citados por Lodi (1998, p. 44), formado por nove perguntas contendo subitens, organizadas de forma a elevar gradualmente a imersão do entrevistado na entrevista e concebidas para buscar situações do cotidiano que pudessem ser traduzidas em modelos de linguagens verbais por voz. A ordem das perguntas foi definida para facilitar a compreensão dos entrevistados acerca do conteúdo pretendido, evoluindo de questões pragmáticas e fáceis de responder a questões que demandam de respostas mais complexas e abstratas. Cada uma das questões foi aplicada no decorrer do diálogo entre o entrevistador e o entrevistado, seguindo a ordem gradual de abstração e dificuldade, partindo de uma questão com conteúdo pragmático ('como uma interface vocal deve ordenar para virar à direita, à esquerda, seguir em frente e retornar?') até a mais abstrata ('como uma interface vocal deve informar sobre a existência de uma depressão à frente, à direita e à esquerda?'). 0 quadro 18, no apêndice " $A$ " (página 194) contém a estrutura sequencial das questões e seu conteúdo.

As seis entrevistas ocorreram ao longo do mês de setembro de 2015. Foram registradas por meio escrito, e duas também foram registradas em áudio. Nenhum dos entrevistados expressou dúvidas quanto ao tema de cada uma das perguntas, e a média de tempo para a entrevista completa foi de 45 minutos. 0 apêndice "B" contém os quadros 19 a 24 (páginas 195 a 200) com a síntese das respostas de cada entrevistado.

Os resultados das entrevistas ofereceram subsídios para a elaboração das construções verbais a serem inseridas no equipamento eletrônico de audionavegação utilizado nos experimentos práticos em local controlado e em locais públicos, além de servirem de base para a compilação dos dados gerais do 
estudo. Os detalhes dos resultados desta entrevista estão no capítulo 4.1, a partir da página 143.

\subsubsection{EXPERIMENTO PRÁTICO EM LOCAL CONTROLADO}

O objetivo deste experimento foi identificar aspectos importantes a serem inclusos na ferramenta que disponibilizaria a audionavegação, esclarecendo algumas particularidades do ato de guiar pessoas com deficiência visual por meio eletrônico, para compreender como ocorreria a interação dos convidados com os equipamentos e com algumas situações ambientais. Esta análise preliminar confirmou a escolha do smartphone como gerador da voz sintetizada, assim como identificou os tipos de fones de ouvido que estariam disponíveis para a escolha dos convidados.

Com a finalidade de disponibilizar ferramentas adequadas para que os voluntários com deficiência visual possam ser guiados por audionavegação nos ambientes públicos de experimentação, foi realizada uma análise preliminar em um ambiente controlado, com local e convidados também cedidos pela ADEVA, em continuação à sua colaboração iniciada com as entrevistas preliminares. A equipe de organização da pesquisa da associação convidou quatro associados com deficiência visual para participarem desta fase do estudo.

Para esta coleta de informações preliminares optou-se pela captação de dados por meio de observação participante (FLICK, 2009, p. 207; CRESWELL, 2014, p. 72) de cada convidado sendo guiado por meio eletrônico em trajetos simulados, buscando-se informações sobre usabilidade que pudessem ser incorporadas à pesquisa principal.

A observação participante foi realizada em dois ambientes preparados e seguros no interior da ADEVA, em três dias distintos, e, semelhantemente à entrevista preliminar, os convidados que participaram desta fase autorizaram sua participação por meio dos termos de consentimento livre e esclarecido, cujos modelos estão no apêndice "F" (página 219), enviados por e-mail a pedido deles para que pudessem ler o termo de forma autônoma com seus próprios aparelhos 
eletrônicos. 0 termo lhes garantiu o anonimato e o conhecimento prévio dos objetivos da entrevista, conforme proposto por Creswell (2014, p. 128).

Posteriormente a cada observação, os convidados forneceram suas considerações sobre a experiência de serem guiados pela voz sintetizada. As observações também foram acompanhadas por uma especialista em orientação e mobilidade da ADEVA, identificada neste estudo como "CM", que forneceu informações elucidativas sobre as ações observadas em cada acompanhamento. Além de ministrar aulas na ADEVA, a experiência de "CM" é reforçada pela convivência com seu marido, que possui cegueira adquirida após adulto.

Durante as experimentações foi utilizado um equipamento eletrônico que fornece indicações de audionavegação por voz sintetizada. Este equipamento eletrônico faz uso de um telefone celular do tipo smartphone, que contém o aplicativo de voz sintetizada, além de gerar alertas hápticos e sonoros. Os aplicativos de voz sintetizada disponibilizados foram o SVOX Luciana TTS (SVOX MOBILE VOICES, 2010) e a Síntese de Voz do Google (GOOGLE INC., 2016). Estes dois aplicativos foram usados porque, no momento da pesquisa, eram os únicos disponíveis em português do Brasil. Quanto ao gênero da voz, o aplicativo SVOX Luciana TTS somente está disponível no gênero feminino, enquanto a Síntese de Voz do Google possui versões em ambos os gêneros. Para não fomentar preferências comerciais, os nomes dos aplicativos não foram disponibilizados para os convidados.

Antes de cada frase de audionavegação, o equipamento emite um alerta sonoro, em forma de melodia de dois tons com duração total de um segundo, que tem o propósito de informar que o equipamento apresentará uma instrução vocal a seguir.

O equipamento foi instalado no local cedido pela ADEVA para disponibilizar as informações sobre os trajetos simulados de forma semelhante à navegação por GPS, mas utilizando somente audionavegação sem informação visual. Os convidados da ADEVA puderam escolher a forma de audição de sua preferência entre quatro opções diferentes de transmissão sonora: 1 - Viva-voz. 2- Fones de ouvido do tipo earphones (dentro do ouvido). 3 - Fones de ouvido do tipo headphones (fora do ouvido). 4 - Fones de condução óssea. À exceção da viva-voz, 
cujo som é gerado diretamente pelo smartphone, os fones utilizavam fios de conexão, por ser o tipo mais comum disponível no mercado. Como características gerais de cada forma de audição, pode-se citar que a viva-voz exige que a pessoa mantenha o smartphone em sua mão, além de tornar possível a outras pessoas ao redor escutarem as instruções, sendo desta forma o meio menos discreto e menos seguro. Já a utilização dos dois tipos de fones auriculares pode prejudicar a audição do ambiente, pois obstruem os ouvidos. Por fim, a utilização de fones de condução óssea não obstrui os ouvidos, permitindo que a pessoa escute as instruções do smartphone sem interferir na audição dos outros sons presentes nos ambientes.

Para registrar o estudo foram utilizadas câmeras de foto e vídeo e um gravador de som. Os resultados foram transcritos, tabulados e classificados, na busca pelos conceitos-chave relacionados às questões pretendidas (JORDAN e PERSSON, 2007, p. 104).

0 primeiro dia de experimentação foi em 21 de outubro de 2015, realizado em um corredor ao ar livre, iniciado a leste da instituição, em rampa leve, com 25 metros de comprimento e dois metros de largura, encerrada por uma curva de noventa graus à esquerda, seguida de outra curva a noventa graus à direita, esta última delimitada por uma porta aberta à oeste. Cada uma das curvas está posicionada a cerca de dois metros uma da outra. Dois percursos foram utilizados neste local, o primeiro no sentido oeste e o segundo no sentido leste. Foi utilizado somente o trecho onde as curvas estavam presentes (figura 24).

Figura 24 - Percursos do primeiro dia, 21/10/2015

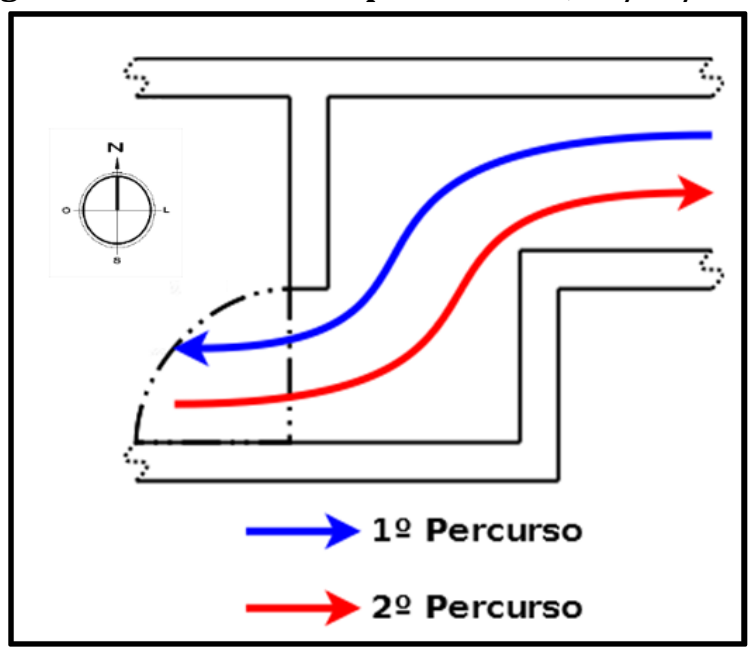

Fonte: do autor (2015) 
As mensagens vocais apresentadas aos convidados, no sentido leste, foram:

a) "Vire à esquerda", quando o convidado chega à curva para o sul.

b) "Porta à direita", quando o convidado se posiciona com a porta à sua direita.

No sentido oeste, as mensagens vocais apresentadas aos convidados foram:

c) "Porta à frente", com a porta à distância de dois metros à frente do convidado.

d) "Vire à esquerda", assim que o convidado atravessa a porta.

e) "Rampa à direita", quando o convidado se posiciona com o corredor à sua direita.

No segundo e no terceiro dia de experimentação foi utilizado o outro ambiente, no pátio da associação, que consiste em uma área quadrada, com vinte metros de lado, com acessos por dois corredores tangenciais ao norte. Neste segundo ambiente os experimentos foram realizados nos dias 10 e 12 de novembro de 2015 . Neste pátio foram preparados outros dois percursos (figura 25).

Figura 25 - Percursos do segundo e terceiro dias, 10 e 12/11/2015

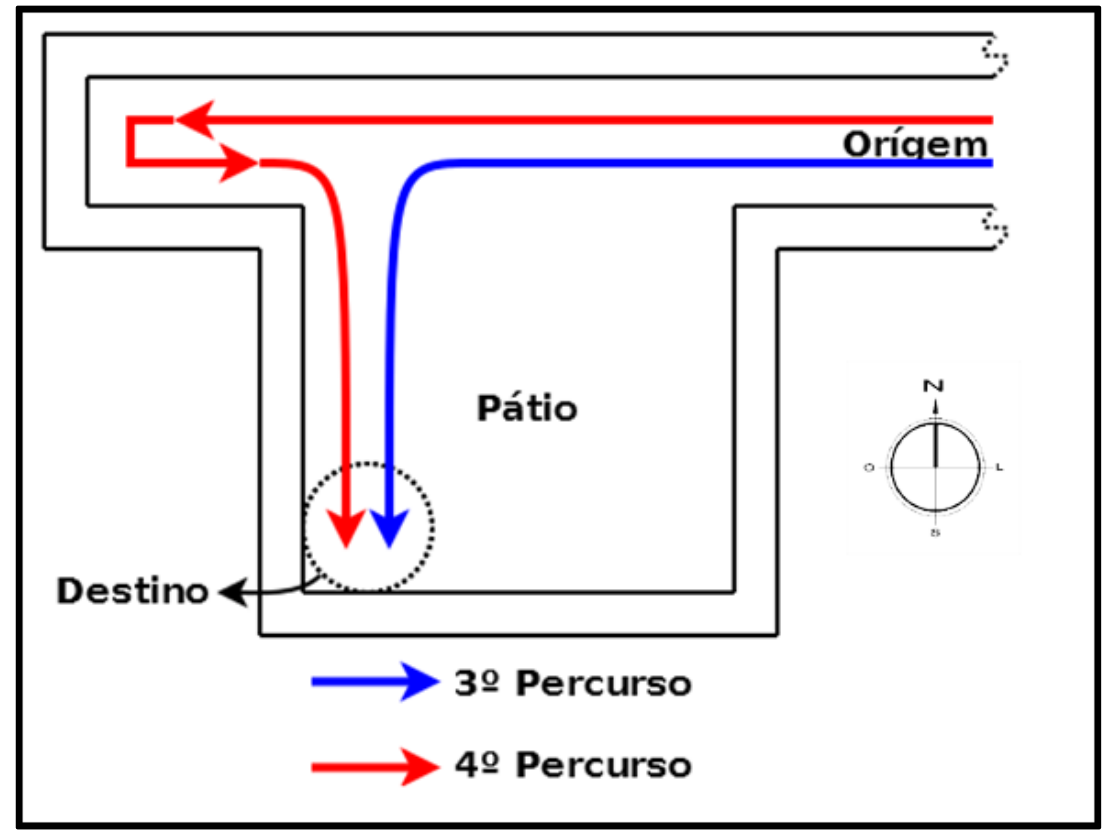

Fonte: do autor (2015) 
O terceiro percurso inicia-se no corredor a leste, seguindo até a borda da parede oeste do pátio, realizando então uma curva à esquerda e seguindo paralelo à parede oeste do pátio, utilizada aqui como linha guia para o convidado, e termina na parede sul do pátio. 0 quarto percurso inicia-se no corredor leste, mas segue direto até o corredor oeste do pátio, e termina em uma parede, quando então faz um retorno em 180 graus, com destino à parede oeste do pátio, novamente utilizando esta como linha guia, terminando no mesmo ponto do primeiro percurso. Este quarto percurso foi planejado para simular uma falha de navegação no terceiro percurso.

Novas frases para o conteúdo da voz sintetizada foram utilizadas para guiar o convidado nestes dois novos percursos. Estas frases, para o terceiro percurso, são:

f) "Siga em frente por vinte passos", no início do segundo percurso.

g) "Vire à esquerda e siga a linha guia à direita", dita quando o convidado chega ao início do corredor oeste.

h) "Você chegou ao destino", dita quando o convidado chega ao final da parede oeste.

Para o quarto percurso, a sequência de frases é esta:

i) "Siga em frente por vinte passos", semelhante ao item "f".

j) "Você está fora da rota, retorne", quando o convidado se aproxima do final do corredor oeste, simulando uma falha de indicação do item "g".

k) "Vire à direita e siga pela linha guia à direita", quando o convidado retorna ao início do corredor oeste.

l) "Você chegou ao destino", idêntica em localização e situação à frase do item "h".

O critério de seleção para solicitar voluntários à ADEVA considerou somente a diferenciação entre pessoas com cegueira e pessoas com baixa visão e que possuem diferenciação em experiência com o uso de aparelhos eletrônicos portáteis com voz sintetizada. Por ordem de acompanhamento, os convidados pela ADEVA foram: 
- "MI", mulher, tem baixa visão severa no olho direito e cegueira no olho esquerdo, adquiridas após a idade adulta. Participou da pesquisa no primeiro e no segundo dia.

- "MA", homem, nasceu com cegueira total em ambos os olhos. Participou da pesquisa no primeiro e no segundo dia;

- "RE", homem, tem baixa visão em ambos os olhos, adquirida após a idade adulta. Participou da pesquisa no segundo dia;

- "CE", mulher, nasceu com cegueira total em ambos os olhos. Participou da pesquisa no terceiro dia.

Não houve mais pessoas disponíveis para esta experiência preliminar. No entanto, os experimentos concretizados forneceram as informações suficientes para a experiência prática em local público, objetivo desta experiência preliminar.

Previamente às observações, os pesquisadores instruíram os convidados sobre a operação do smartphone e sobre as escolhas de recursos de transmissão sonora. Após esta breve instrução, os convidados foram observados ao realizarem caminhadas pelos trechos apresentados, seguindo-se de um breve diálogo quando cada convidado ofereceu suas impressões sobre sua participação.

Os resultados deste experimento prático, descritos no capítulo 4.2 a partir da página 145, foram unificados aos resultados das entrevistas para obtenção dos conteúdos de verbalização e forneceram subsídios para a preparação e a compilação dos dados do experimento de audionavegação em ambientes públicos. 


\subsection{AUDIONAVEGAÇÃO EM AMBIENTES PÚBLICOS}

Com a necessidade de conhecer as peculiaridades da utilização de audionavegação em ambientes públicos para pessoas com deficiência visual, neste estudo foram utilizadas as informações obtidas nos experimentos preliminares, que possibilitaram a preparação dos ambientes e ferramentas para documentar a observação da utilização de audionavegação em locais públicos.

Segundo DISCHINGER (2000, p. 141), em pesquisa com pessoas com deficiência visual, as informações precisam ser obtidas diretamente das pessoas. Assim, efetuou-se a aquisição de dados por meio de observação participante (FLICK, 2009, p. 207; CRESWELL, 2014, p. 72) durante a caminhada de cada voluntário.

\subsubsection{FERRAMENTAS E LOCAIS}

Este experimento foi realizado em um trajeto que atravessa três ambientes públicos distintos, com características e recursos de acessibilidade diversificados. Os três ambientes são de uso comum para as pessoas, independentemente de possuírem ou não quaisquer tipos de deficiências, e o experimento foi realizado em horários livres, com a presença comum de outras pessoas não relacionadas à pesquisa.

Para registrar o estudo, foram utilizados equipamentos audiovisuais. Os resultados foram transcritos, tabulados e classificados, na busca pelos conceitos-chave relacionados às questões pretendidas (JORDAN e PERSSON, 2007, p. 104).

Como voluntários, foram convidadas pessoas com deficiência visual que possuem características diferentes com relação ao seu grau de deficiência, sua experiência com autonomia em orientação e mobilidade, sua familiaridade com os locais do experimento, e sobre sua experiência na utilização de diferentes ferramentas de orientação e mobilidade.

Cada voluntário recebeu por meio digital (e-mail) um termo de consentimento livre e esclarecido, solicitando sua autorização para realizar a pesquisa. 0 termo foi composto pelo objetivo, justificativa da pesquisa, forma de participação e dados pessoais do pesquisador e da universidade, para que pudessem entrar em contato 
caso fosse necessário. Cópias dos termos, que são diferentes somente pelo gênero do voluntário, estão no apêndice "F" (página 219) deste trabalho. A opção de enviar os termos por meio digital tornou possível a cada voluntário utilizar suas ferramentas pessoais de leitura, decidindo autonomamente sobre sua participação. Ao aceitar sobre a participação, foi realizado o agendamento para os voluntários se dirigirem ao local do experimento, quando cada voluntário trouxe uma cópia assinada do termo. Desta forma, buscou-se manter a clareza dos objetivos e o anonimato de todos os participantes, ao adotar-se o posicionamento ético para pesquisas qualitativas, de acordo com FLICK (2009, p. 54 a 56).

Para cumprir o trajeto planejado para as observações, os voluntários receberam um smartphone que forneceu a audionavegação dos ambientes. Utilizando voz sintetizada, o smartphone serviu para informar as opções disponíveis em cada situação de tomada de decisão, possibilitando aos voluntários a escolha de cada opção, de acordo com suas preferências.

O trajeto iniciou-se na porta de saída do trem para pessoas com deficiência visual, na plataforma de desembarque oeste da Estação Vergueiro do Metrô de São Paulo, situada no número 790 da Rua Vergueiro, bairro da Bela Vista, cidade de São Paulo. 0 pesquisador forneceu aos voluntários a tarefa de caminhar até a biblioteca Louis Braille, localizada no interior do Centro Cultural São Paulo, que fica no número 1000 da Rua Vergueiro, também no bairro da Bela Vista, cidade de São Paulo. Assim foram fornecidas, para cada voluntário, somente duas informações sobre o trajeto a ser seguido: a origem, na plataforma oeste da Estação Vergueiro onde cada voluntário iniciou a caminhada, e o destino pretendido, na porta de entrada da biblioteca Louis Braille no interior do Centro Cultural São Paulo. Todo o trajeto entre a origem e o destino foi escolha do voluntário, baseando-se nas informações fornecidas pelo smartphone por meio da audionavegação. 
Os croquis dos espaços para os trajetos no primeiro ambiente público, a estação Vergueiro do Metrô, estão mostrados nas figuras 26, 27 e 28, páginas 128, 129 e 130.

Figura 26 - Croqui: plataforma oeste da Estação Vergueiro

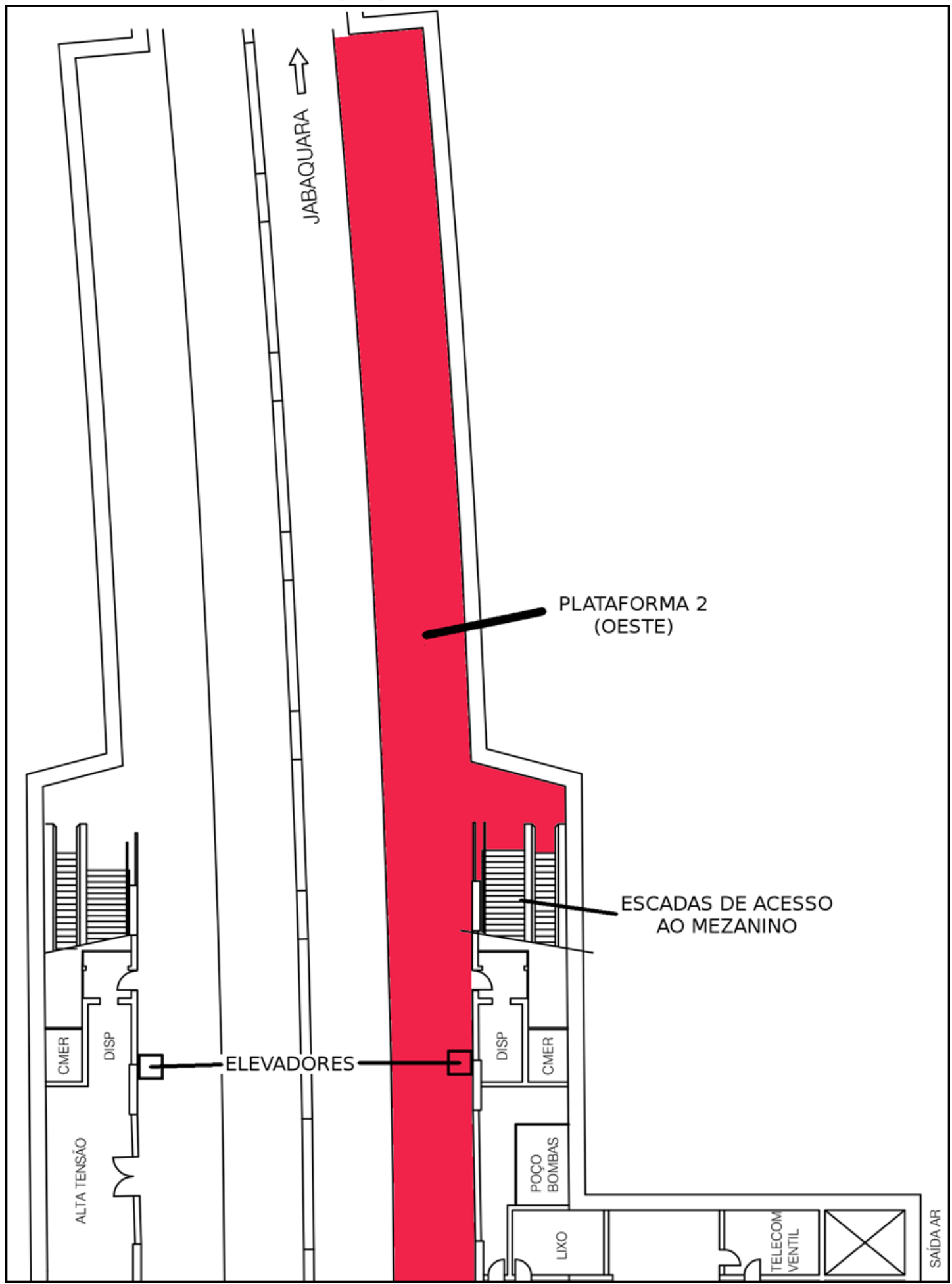

Fonte: do autor (2016) 
Figura 27 - Croqui: mezanino lado oeste da Estação Vergueiro

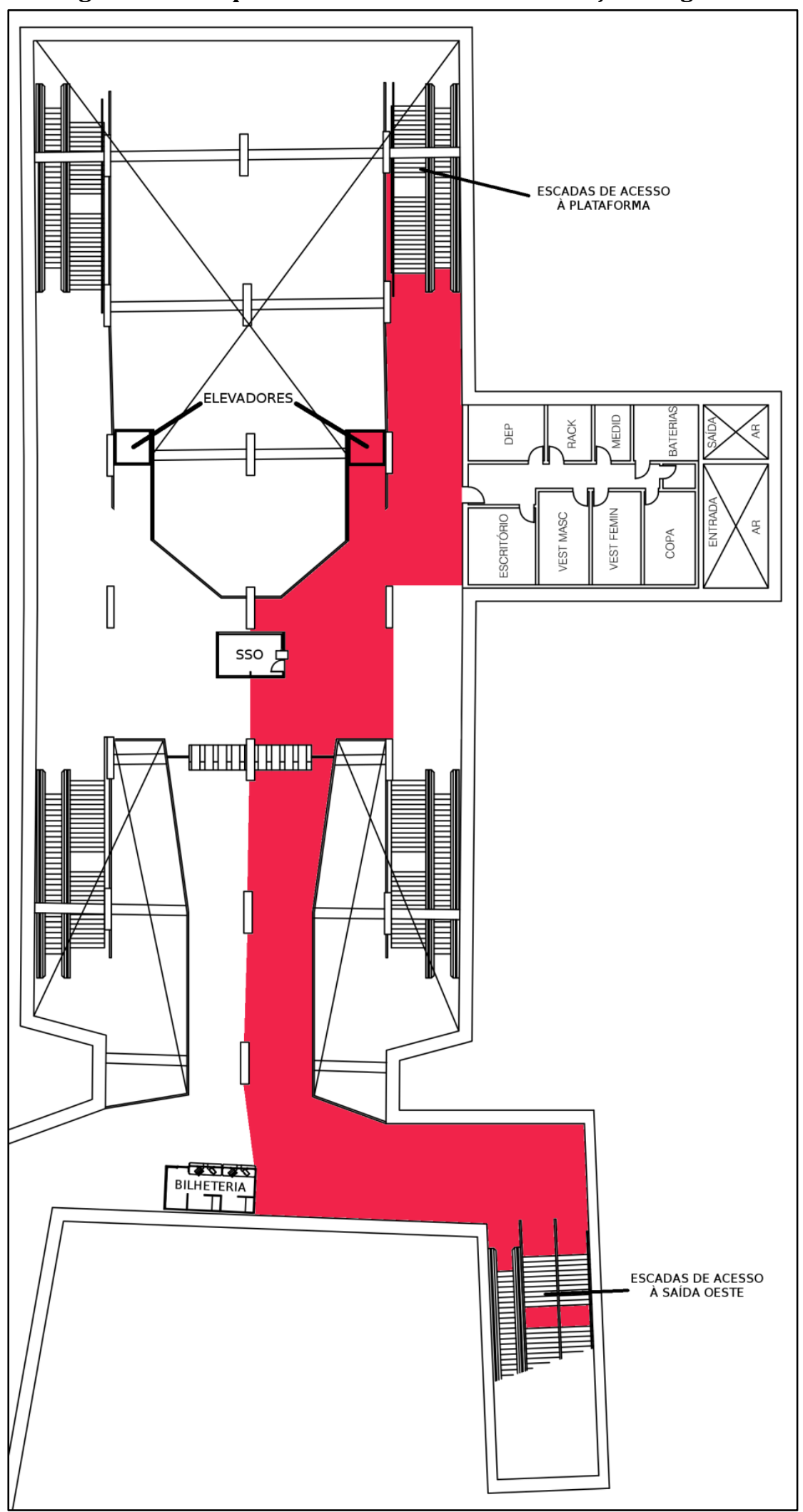

Fonte: do autor (2016) 
Figura 28 - Croqui: acesso externo oeste da Estação Vergueiro

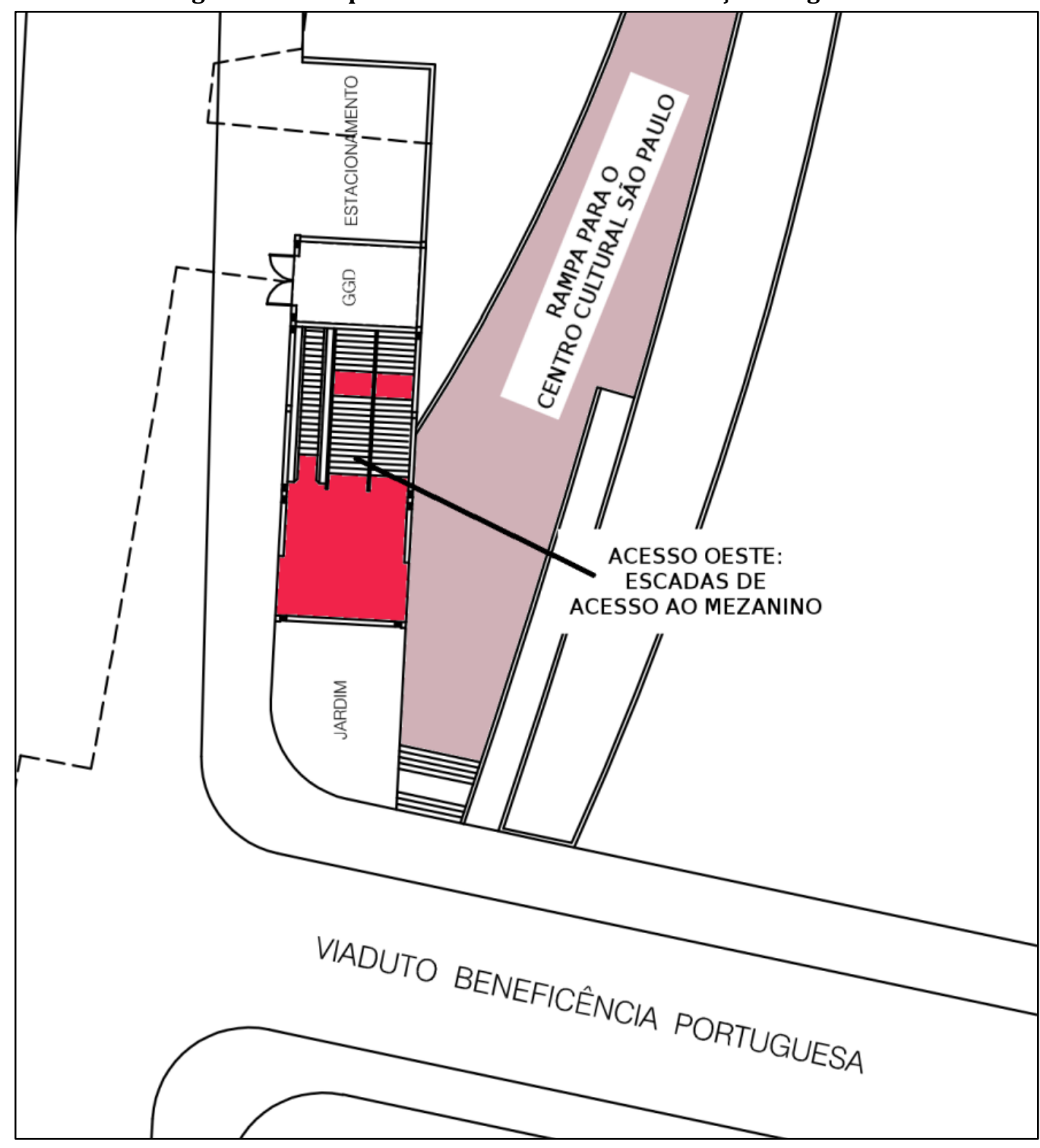

Fonte: do autor (2016) 
O segundo ambiente é o calçamento público em área aberta que faz a ligação entre a Estação Vergueiro e o Centro Cultural São Paulo. Consiste de uma rampa em área aberta, com cerca de 120 metros, delimitada por muretas em ambos os lados. A partir da Estação Vergueiro, esta rampa é em aclive, e segue do Acesso Oeste da estação até os portões do Centro Cultural São Paulo (figura 29).

Figura 29 - Croqui: rampa para o Centro Cultural São Paulo

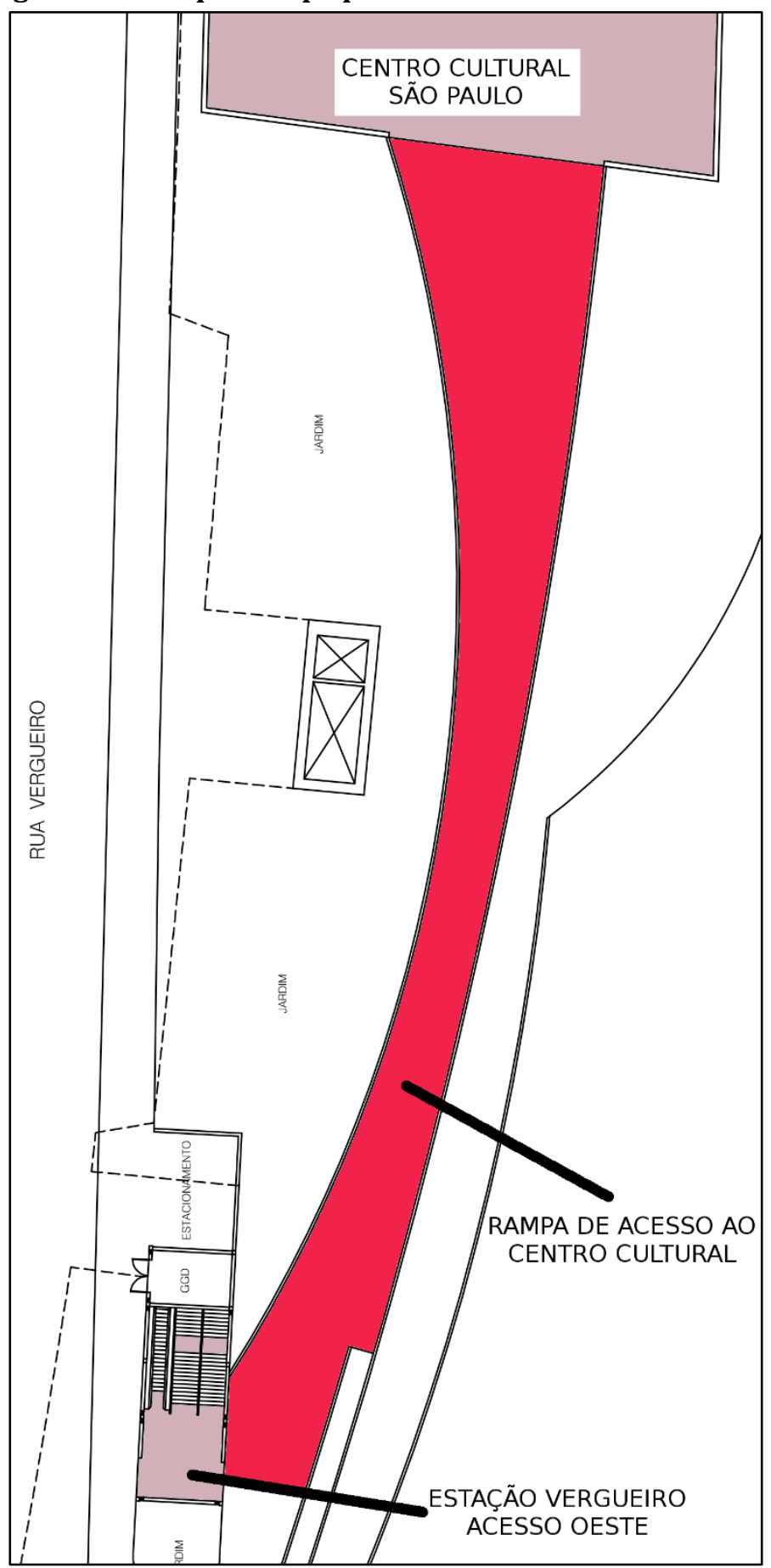

Fonte: do autor (2016) 
0 terceiro ambiente do trajeto inicia-se assim que o voluntário acessa os portões do Centro Cultural São Paulo. É uma área pública, coberta, que disponibiliza serviços culturais aos cidadãos. Dentre os serviços está a biblioteca Louis Braille, que possui um acervo para pessoas com deficiência visual. A biblioteca está localizada no interior do Centro Cultural, com acesso facilitado ao público alvo por meio de piso tátil instalado a partir dos portões (figura 30).

Figura 30 - Croqui: Centro Cultural São Paulo (acesso à biblioteca)

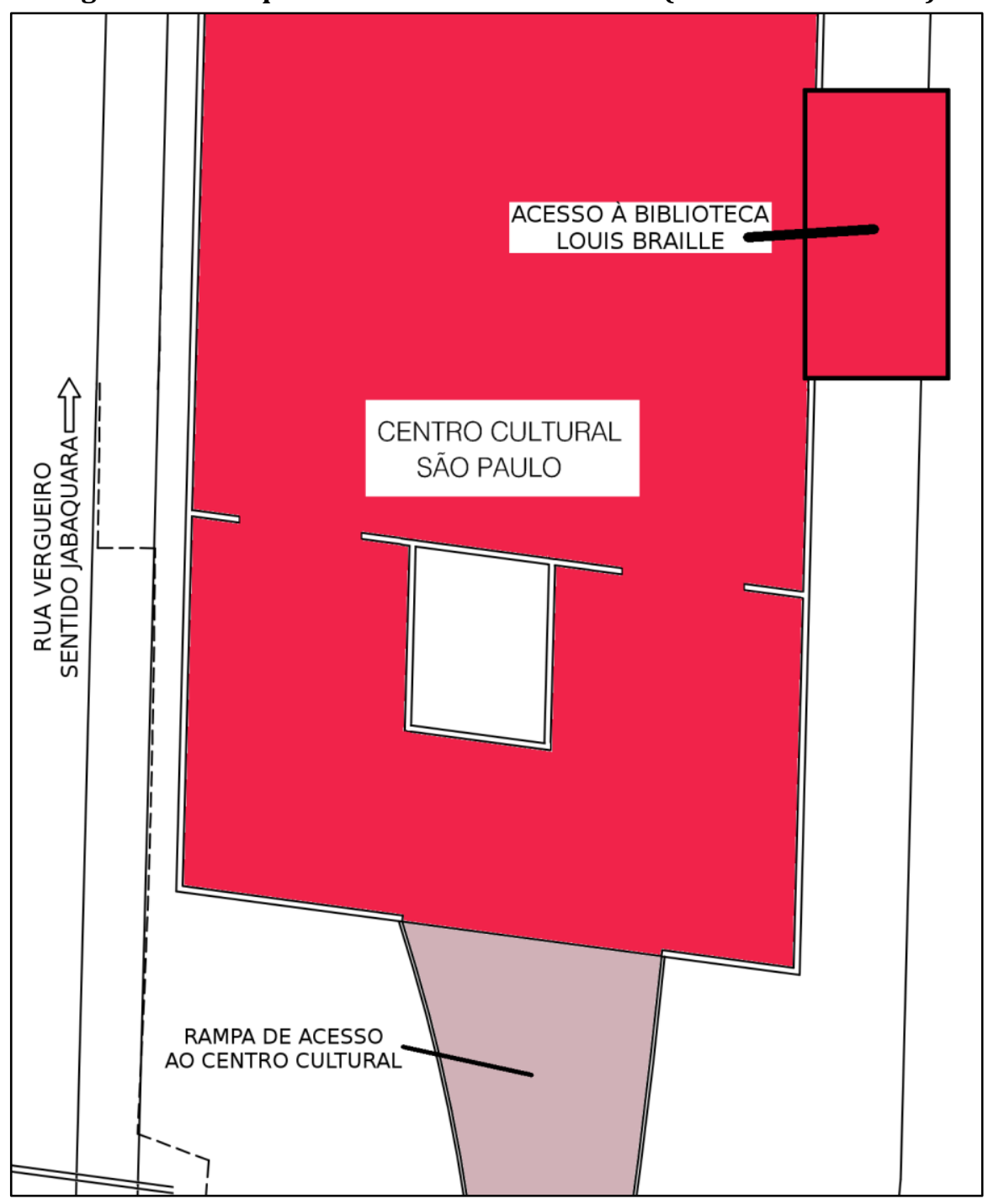

Fonte: do autor (2016) 
Tanto a estação Vergueiro do Metrô quanto o interior do Centro Cultural São Paulo cumprem as adequações para pessoas com deficiência, de acordo com o decreto federal 5296 (BRASIL, 2 dez. 2004), então ambos os espaços possuem piso tátil. Nestes locais, a audionavegação programada no smartphone forneceram informações que permitiram aos voluntários a escolha de seguir ou não o piso tátil, quando existiu esta possibilidade. No entanto, a maioria do trajeto dentro da estação e do Centro Cultural foi realizada sobre o piso tátil, por estar instalado no caminho comum a todas as pessoas.

Devido à inexistência do piso tátil nas calçadas públicas que ligam a estação Vergueiro ao Centro Cultural São Paulo, os voluntários seguiram utilizando somente a audionavegação, algumas vezes auxiliados pela mureta de delimitação da calçada, que serviu de linha guia.

$\mathrm{Na}$ estação, foram utilizadas a plataforma oeste, o lado oeste do mezanino e o acesso oeste da estação. Todos os níveis podem ser acessados por meio de escadas fixas, escadas rolantes e elevadores. 0 trajeto no interior da estação Vergueiro passa por três pavimentos ligados por escadas fixas e escadas rolantes. No trajeto, o nível da plataforma no segundo subsolo é ligado por uma escada rolante e uma escada fixa para o mezanino no primeiro subsolo (foto 6).

Foto 6 - Escadas que levam da plataforma para o mezanino

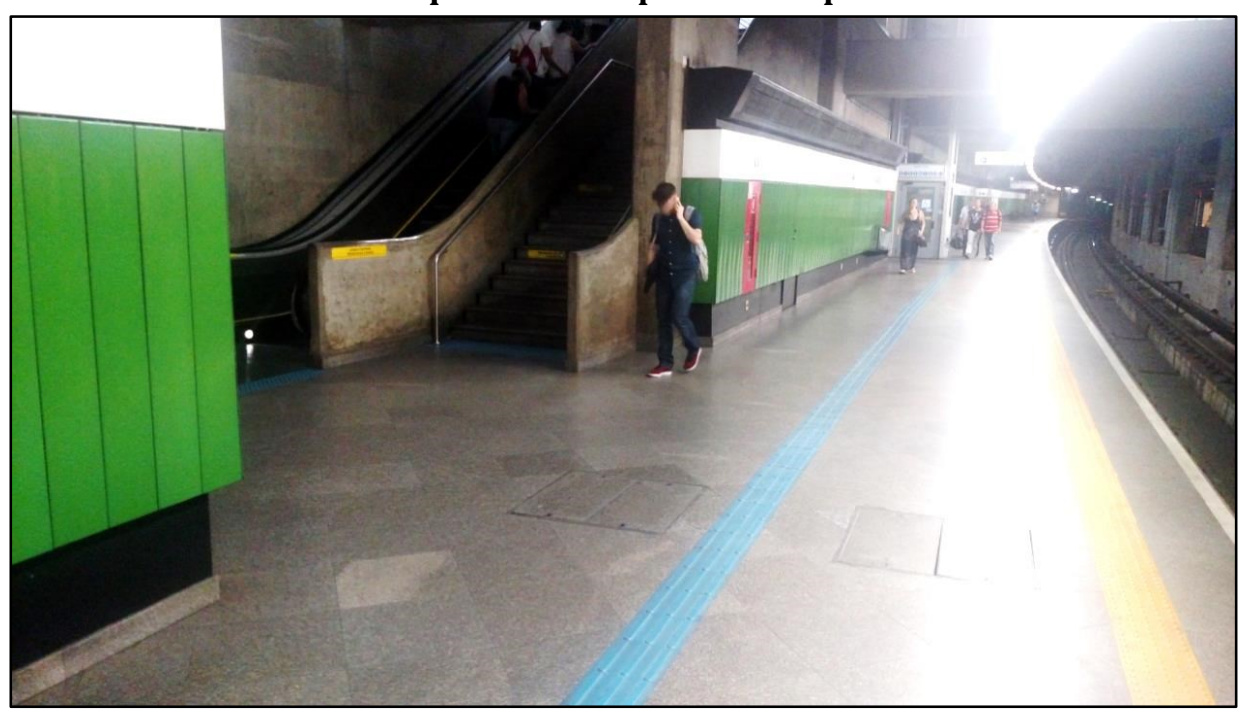

Fonte: o autor (2016) 
O mezanino é ligado ao acesso oeste da estação, no nível da rua, por duas escadas fixas e uma escada rolante. Nestas escadas há piso tátil que direciona para a escada fixa central (Foto 7).

Foto 7 - Escadas que levam do mezanino para o acesso oeste

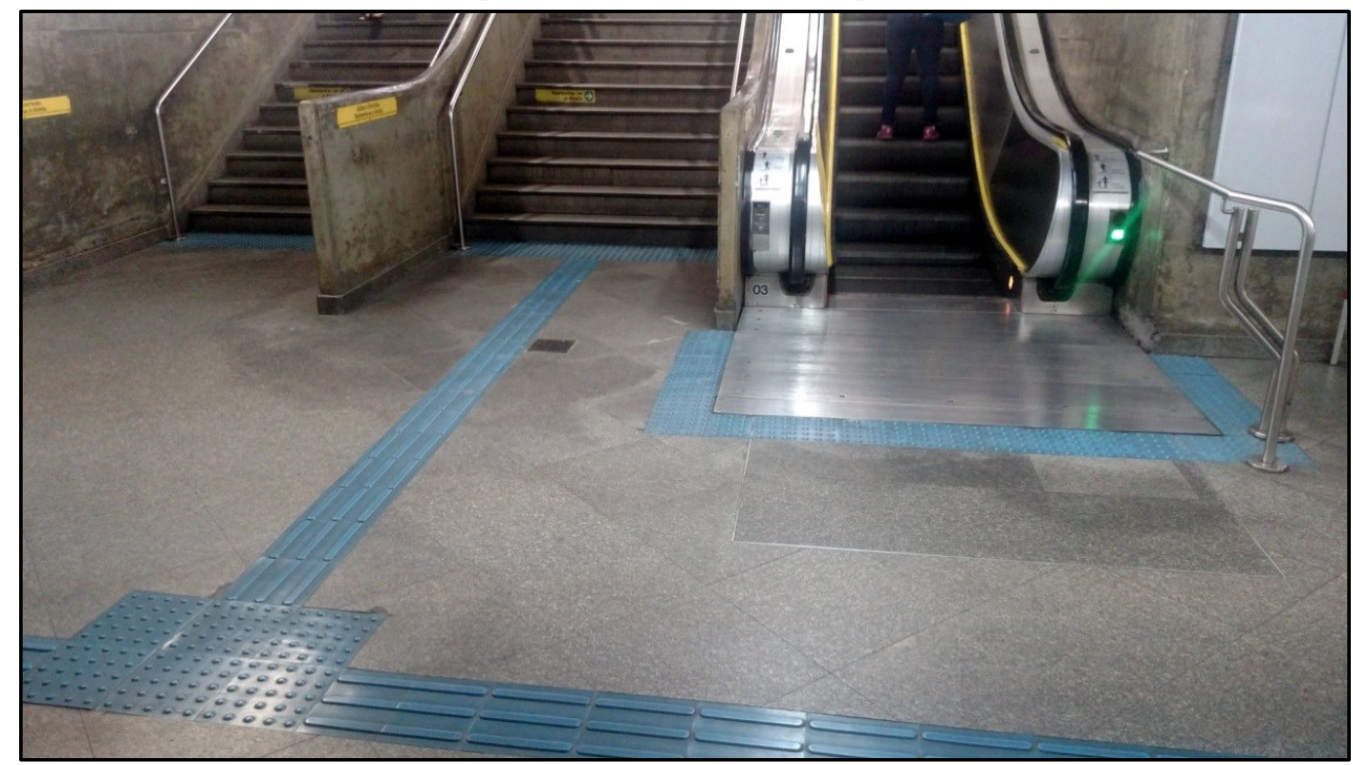

Fonte: o autor (2016)

Para este estudo foi escolhido o design de audionavegação por audiodescrição ambiental. Este formato viabiliza maior liberdade de escolha para a pessoa com deficiência visual, pois descreve o ambiente em que está imerso ao invés de fornecer simples indicações vocais de direcionamento, além de dispensar a necessidade de o usuário programar previamente um destino na interface.

Para que a audionavegação pudesse fornecer informações relevantes para os voluntários, os conteúdos verbais foram planejados para serem apresentados em momentos adequados ao trajeto. Foram elaborados dezenove conteúdos verbais para serem utilizados em locais específicos ao longo do trajeto, utilizando-se os conceitos obtidos nas entrevistas e nos experimentos anteriores.

Sendo a interface vocal semelhante à voz humana, foi inserida uma melodia antes de cada verbalização da audionavegação, criando um contraste sonoro ao ambiente e às vozes de outras pessoas, para que os voluntários pudessem perceber que a voz que se seguiria é uma instrução do equipamento. A melodia escolhida é uma composição de dois tons tocados em um instrumento sintetizado semelhante 
a uma flauta. É agradável aos ouvidos, pois é neutra e utiliza tons suaves, seu volume sonoro não ofusca e tampouco é ofuscado pelo áudio subsequente. Os dois tons utilizados são facilmente identificáveis, pois e não compõem uma melodia usual nos ambientes públicos e suas frequências estão compreendidas entre 500 $\mathrm{Hz}$ e $1000 \mathrm{~Hz}$, indicados por Medeiros (2002) como o ponto central da percepção auditiva humana.

Para que os voluntários pudessem seguir as instruções, foi necessário calcular as distâncias entre o início de cada frase e os locais os quais cada frase se refere, levando-se em conta a velocidade média de uma pessoa com deficiência visual caminhando. De acordo com Ribeiro et al. (2010, p. 30), a velocidade média das pessoas com deficiência visual caminhando é de 0,6 m/s. Assim, para que a frase mais curta, de 2 segundos, possa ser completamente ouvida, é necessário que o som se inicie no mínimo a 1,2 metros antes. No caso das maiores frases, de sete segundos, seu início foi de no mínimo, 4,2 metros de distância antes do ponto de interesse. A tabela 1 demonstra esta relação tempo x distância a percorrer, com base na velocidade média de 0,6 m/s, considerando-se frases com tamanhos entre 2 e 10 segundos:

Tabela 1 - Cálculo médio de distâncias a percorrer com base no tempo das frases

\begin{aligned} & \hline Tempo da frase Distância mínima a percorrer \\ & \hline 2 segundos 1 metro e 20 centímetros \\ & \hline 3 segundos 1 metro e 80 centímetros \\ & \hline 4 segundos 2 metros e 40 centímetros \\ & \hline 5 segundos 3 metros \\ & \hline 6 segundos 3 metros e 60 centímetros \\ & \hline 7 segundos 4 metros e 20 centímetros \\ & \hline 8 segundos 4 metros e 80 centímetros \\ & \hline 9 segundos 5 metros e 40 centímetros \\ & \hline 10 segundos 6 metros \\ & \hline\end{aligned}

Fonte: do autor (2016) com base em Ribeiro et al. (2010, p. 30)

As instruções verbais e seus respectivos tamanhos, em segundos, estão listados no quadro 11 (página 136). Nota-se que as frases ditas pela audionavegação possuem tempos relacionados à quantidade de informações ambientais na vocalização. Os tempos de cada frase variam bastante, entre dois e sete segundos, e são compostos de cada frase precedida pela melodia, que tem 1 segundo de comprimento. 
Observa-se também que conteúdos verbais foram divididos em dois tipos: conteúdos comuns, que podem ser utilizados em mais de um local ao longo do trajeto, e conteúdos verbais específicos, que estão relacionados a locais exclusivos no trajeto.

Quadro 11 - Conteúdos verbais da observação prática

\begin{tabular}{|c|c|c|}
\hline Tipo & Conteúdo verbal & Duração \\
\hline \multirow{5}{*}{$\begin{array}{r}\text { Conteúdos } \\
\text { verbais } \\
\text { comuns }\end{array}$} & Direita. & 2 segundos \\
\hline & Esquerda. & 2 segundos \\
\hline & Siga a parede. & 3 segundos \\
\hline & Siga o piso tátil. & 3 segundos \\
\hline & Chegando no elevador. & 3 segundos \\
\hline \multirow{13}{*}{$\begin{array}{l}\text { Conteúdos } \\
\text { verbais } \\
\text { específicos }\end{array}$} & Esquerda: escadas. Frente: elevador. & 5 segundos \\
\hline & Saída à esquerda. & 3 segundos \\
\hline & Escadas à direita. Primeira, fixa. Segunda, rolante. & 7 segundos \\
\hline & Esquerda: Centro Cultural. Direita: Colégio Santo Agostinho. & 6 segundos \\
\hline & $\begin{array}{l}\text { Esquerda: Centro Cultural. Direita: ponto de ônibus e táxi da Rua } \\
\text { Vergueiro. }\end{array}$ & 7 segundos \\
\hline & Esquerda: Centro Cultural. Direita: Viaduto Beneficência. & 7 segundos \\
\hline & Escadas à direita. Primeira: rolante. Segunda e terceira: fixas. & 7 segundos \\
\hline & Você está seguindo no sentido Centro Cultural São Paulo. & 5 segundos \\
\hline & Bem-vindo ao Centro Cultural São Paulo. & 4 segundos \\
\hline & Direita: biblioteca. Frente: lanchonete. & 5 segundos \\
\hline & Esquerda: pista de dança. Frente: Biblioteca. & 5 segundos \\
\hline & Esquerda: biblioteca. Direita: saída Metrô Vergueiro. & 6 segundos \\
\hline & Bem-vindo à Biblioteca Louis Braille. Um atendente o acompanhará. & 6 segundos \\
\hline
\end{tabular}

\section{Fonte: o autor (2016)}

O apêndice "E", página 205, contém os croquis dos locais onde estas construções verbais são utilizadas, e as vozes sintetizadas estão disponíveis na internet por meio dos códigos de barra mostrados no apêndice “G”, na página 225.

Devido ao alto nível de ruído presente nos ambientes públicos utilizados, a vivavoz dos smartphones poderia não ser suficiente para a correta compreensão das instruções da audionavegação. 0 destaque ficou para a plataforma da estação Vergueiro do Metrô que, por ser um ambiente fechado com circulação de trens, demonstrou ser bem ruidosa, principalmente nos momentos de entrada e saída do trem. 0 nível de ruído, nestes instantes, ficou em torno dos $74 \mathrm{~dB}$ (decibel) com picos de $78 \mathrm{~dB}$, equivalente a uma avenida com circulação intensa de veículos. Sem o trem, o ruído da mesma plataforma ficou em torno dos $51 \mathrm{~dB}$, com picos de 53 $\mathrm{dB}$, equivalente ao som de uma conversação entre duas pessoas (figura 31, página 137). 
Figura 31 - Medição de ruído na plataforma da Estação Vergueiro

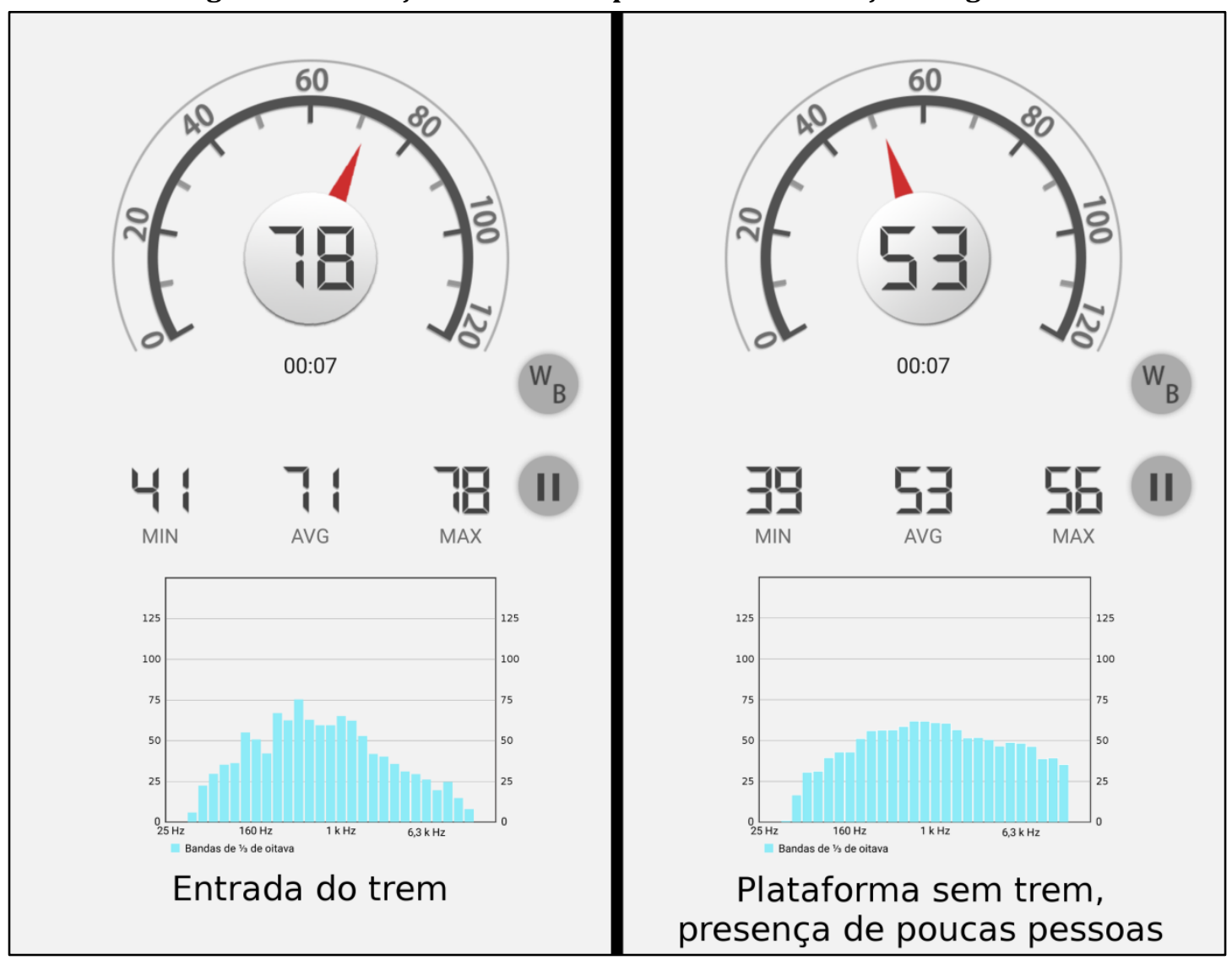

Fonte: o autor (2016) por meio do aplicativo "Sound Meter" no smartphone

Observa-se, pelas mensurações, que a zona do ruído está localizada bem no meio da capacidade humana de percepção sonora, e com um volume que sobrepõe conversação humana convencional. Ao combinar esta medida no gráfico de capacidade da faixa sonora humana, pode-se observar melhor esta sobreposição quase total do ruído da estação sobre a faixa de voz média das pessoas. Pode-se observar melhor este efeito de sobreposição na figura 32 na página 138, com as barras vermelhas representando o ruído na estação. 
Figura 32 - Sobreposição do ruído da plataforma no gráfico de audição humana

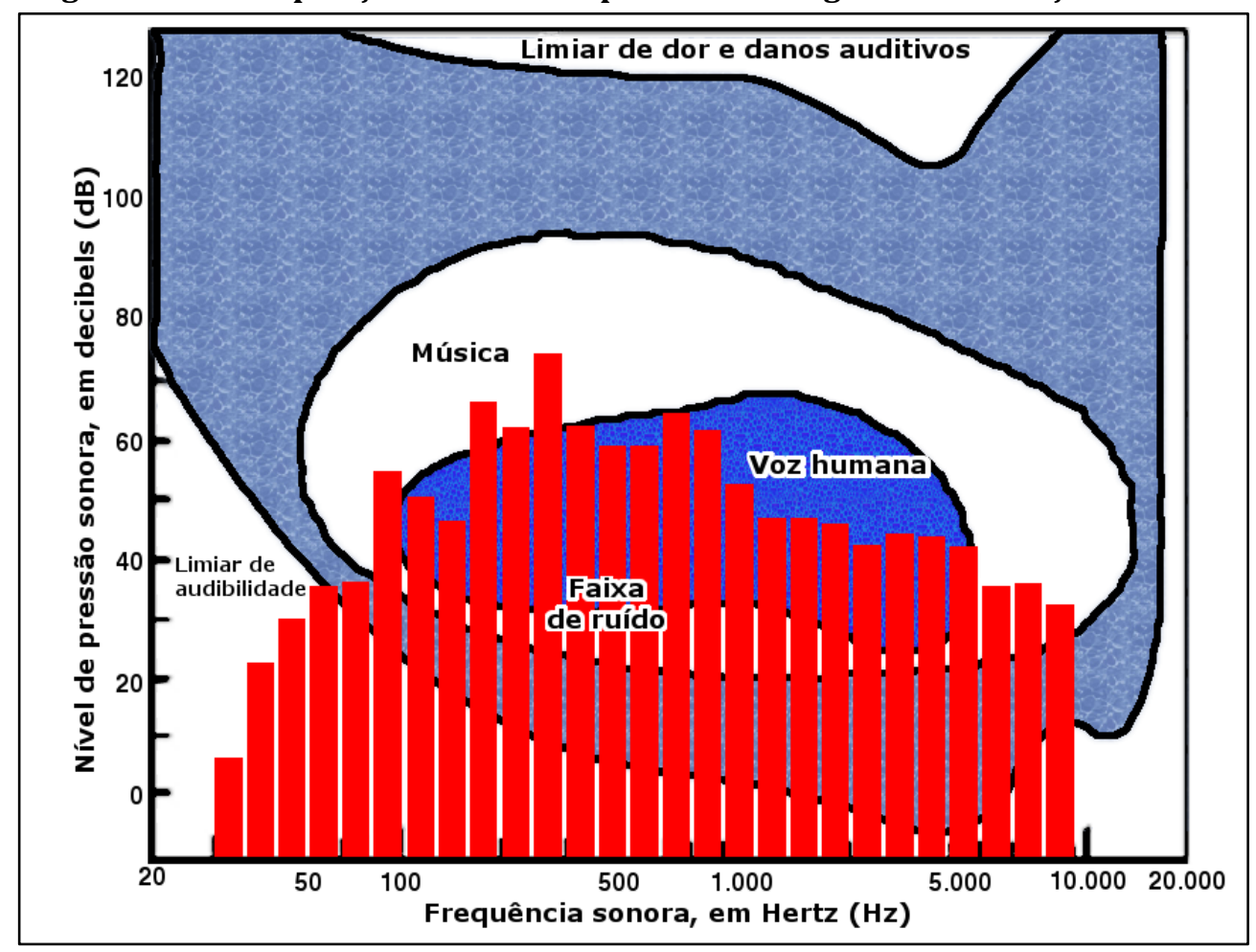

Fonte: o autor (2016)

Por este motivo, à semelhança do experimento prático na ADEVA, foi disponibilizada aos voluntários a escolha de três aparelhos para audição, além da viva-voz do smartphone: fones do tipo earphone (dentro do ouvido), fones do tipo headphone (presos sobre a cabeça) e fones de condução óssea (presos sobre as orelhas, sem entrar nos ouvidos), os três tipos sem fio (foto 8).

Foto 8 - Fones disponibilizados para os voluntários

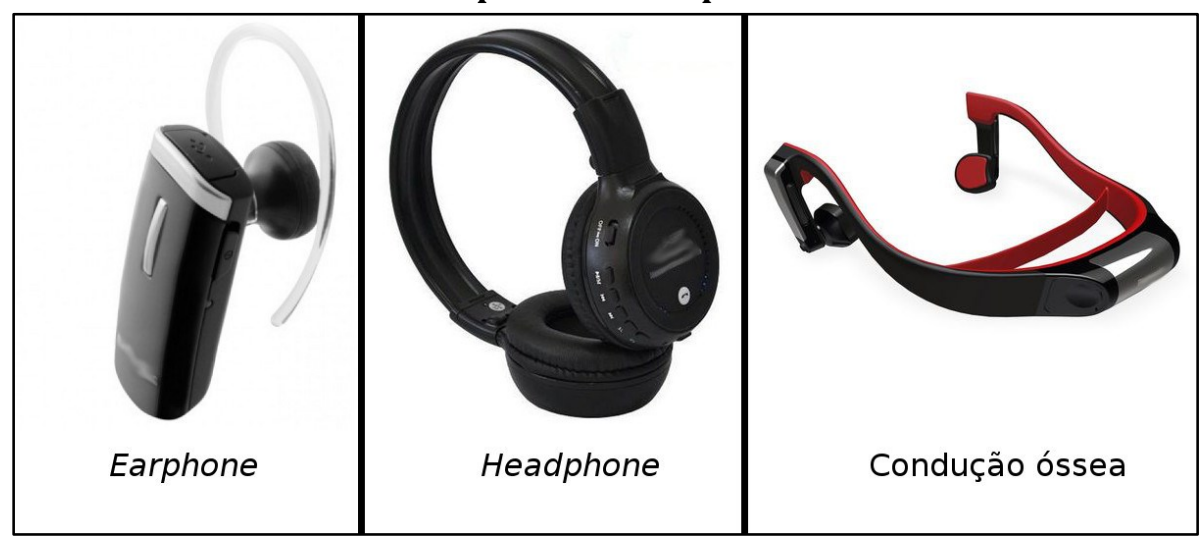

Fonte: o autor (2016) 
Para a seleção dos voluntários a participar desta fase da pesquisa, foi solicitada à Gerência de Operações do Metrô de São Paulo que realizasse um convite aos seus usuários cadastrados que têm deficiência visual. Devido aos experimentos ocorrerem em ambientes públicos, adotou-se como condições básicas de seleção a escolha de voluntários adultos, com cegueira ou com baixa visão, e sem a presença de outras deficiências físicas, mentais ou sensoriais que pudessem interferir na percepção da audionavegação ou dificultar sua locomoção pelos espaços públicos e na estação do Metrô. Desta forma, o Metrô de São Paulo convidou usuários com as características solicitadas.

Como esta pesquisa prática buscou peculiaridades na possibilidade do uso de audionavegação para orientar a mobilidade de pessoas com deficiência visual em ambientes públicos e transportes de massa, por meio de observações exploratórias, buscou-se selecionar voluntários com diferentes características físicas, cognitivas e de autonomia, dentro da esfera da deficiência visual, dentre os convidados pelo Metrô de São Paulo, chamados por telefone a participarem da pesquisa na medida em que esta ocorria, possibilitando assim uma análise na busca pela saturação de dados antes de chamar o próximo voluntário, definindo-se assim a quantidade de voluntários, conforme os preceitos citados por Flick (2009, p. 120).

Assim, no quinto voluntário os dados estavam saturados, percebendo-se este efeito após a análise dos dados do sexto e do sétimo voluntários, que confirmaram a saturação de dados.

Por ordem alfabética, os voluntários foram:

- DA: mulher, idade entre 30 e 40 anos. DA é funcionária pública estadual, e possui ensino superior. Tem cegueira congênita. Fez treinamento de orientação e mobilidade, e caminha com autonomia em espaços públicos. Utiliza piso tátil e bengala longa. Não tem familiaridade com os locais públicos utilizados no experimento. Tem pouca experiência com smartphones. Participou da pesquisa no dia 5 de agosto de 2016.

- EA: homem, idade entre 30 e 40 anos. EA é jornalista. Possui cegueira total congênita. Possui treinamento de orientação e mobilidade, e caminha com 
autonomia em espaços públicos. Utiliza piso tátil e bengala longa. Não tem familiaridade com os locais públicos utilizados no experimento. Utiliza smartphone e computadores que possuem recursos de acessibilidade. Participou da pesquisa no dia 26 de julho de 2016.

- IC: mulher, idade entre 30 e 40 anos. IC trabalha como analista de redes sociais e tem ensino médio. Possui deficiência visual severa congênita em ambos os olhos, não tem capacidade de definição de cores tampouco de formas, somente percebe claro e escuro. Não possui treinamento de autonomia e mobilidade, e depende de guia vidente para caminhar em locais públicos. Não utiliza piso tátil, mas utiliza bengala longa. Tem familiaridade com a Estação Vergueiro do Metrô, mas somente a utiliza com acompanhamento de guia vidente. Não tem familiaridade com o Centro Cultural São Paulo. Utiliza smartphone e computadores que possuem recursos de acessibilidade. Participou da pesquisa no dia 22 de julho de 2016.

- MR: homem, idade entre 40 e 50 anos. MR é analista de sistemas. Possui deficiência visual severa congênita, não define formas, mas define cores, claro e escuro. Não tem treinamento de orientação e mobilidade, mas caminha com autonomia em espaços públicos. Utiliza piso tátil e bengala longa. Não tem familiaridade com os locais públicos utilizados no experimento. Utiliza smartphone e computadores que possuem recursos de acessibilidade. Participou da pesquisa no dia 31 de julho de 2016. Já havia participado das entrevistas preliminares.

- RB: homem, idade entre 50 e 60 anos. RB é arquiteto e trabalha como locutor de rádio. Possui cegueira total adquirida após adulto. Não possui treinamento de autonomia e mobilidade, mas caminha com autonomia em locais públicos, desenvolvendo suas próprias técnicas e métodos para isso. Utiliza piso tátil e bengala longa. Tem familiaridade com a Estação Vergueiro do Metrô, mas não tem familiaridade com o Centro Cultural São Paulo. Utiliza smartphone, outros aparelhos eletrônicos portáteis e computadores que possuem recursos de acessibilidade. Participou da pesquisa no dia 14 de julho de 2016. À semelhança de MR, também havia participado das entrevistas preliminares. 
- RC: mulher, idade entre 40 e 50 anos. RC é professora, e possui ensino superior. Possui cegueira total congênita. Tem treinamento de orientação e mobilidade, e caminha com autonomia em espaços públicos. Utiliza piso tátil e bengala longa. Tem familiaridade com os locais do experimento, inclusive com o trajeto, pois faz uso da biblioteca Louis Braille. Não utiliza smartphone regularmente. Participou da pesquisa no dia 28 de julho de 2016.

- SE: homem, idade entre 30 e 40 anos. SE é jornalista. Possui cegueira adquirida após adulto. Tem treinamento de orientação e mobilidade e treinamento para uso de cão-guia com adestramento em inglês, e caminha com autonomia em espaços públicos. Utiliza piso tátil e cão-guia. Não tem familiaridade com os locais públicos utilizados no experimento. Utiliza smartphone e computadores que possuem recursos de acessibilidade. Participou da pesquisa no dia 26 de julho de 2016, antes da participação de EA. Já havia oferecido suas opiniões nas entrevistas preliminares.

No objetivo de favorecer a análise dos dados obtidos, os voluntários foram categorizados de acordo com suas experiências relacionadas à capacidade de autonomia em orientação e mobilidade (OM), e na familiaridade com os ambientes pesquisados, com recursos para a acessibilidade e com sua o uso de smartphones. 0 levantamento dessas informações está mostrado na tabela 2.

Tabela 2 - Levantamento das experiências com OM dos voluntários

\begin{tabular}{|c|c|c|c|c|c|c|c|}
\hline & \multicolumn{7}{|c|}{ Voluntários } \\
\hline & DA & EA & IC & MR & RB & RC & SE \\
\hline Sexo: & Fem. & Masc. & Fem. & Masc. & Masc. & Fem. & Masc. \\
\hline Cegueira? & $\checkmark$ & $\checkmark$ & & & $\checkmark$ & $\checkmark$ & $\checkmark$ \\
\hline Baixa visão? & & & $\checkmark$ & $\checkmark$ & & & \\
\hline Deficiência congênita? & $\checkmark$ & $\checkmark$ & $\checkmark$ & $\checkmark$ & & $\checkmark$ & \\
\hline Deficiência adquirida? & & & & & $\checkmark$ & & $\checkmark$ \\
\hline Treinamento de orient. e mobilidade? & $\checkmark$ & $\checkmark$ & & & & $\checkmark$ & $\checkmark$ \\
\hline Autonomia em espaços públicos? & $\checkmark$ & $\checkmark$ & & $\checkmark$ & $\checkmark$ & $\checkmark$ & $\checkmark$ \\
\hline Usa bengala longa? & $\checkmark$ & $\checkmark$ & $\checkmark$ & $\checkmark$ & $\checkmark$ & $\checkmark$ & \\
\hline Usa piso tátil? & $\checkmark$ & $\checkmark$ & & $\checkmark$ & $\checkmark$ & $\checkmark$ & $\checkmark$ \\
\hline Usa cão guia? & & & & & & & $\checkmark$ \\
\hline Familiaridade com os locais da pesquisa? & & & $*$ & & $\checkmark$ & $\checkmark$ & $\checkmark$ \\
\hline Usa smartphone regularmente? & & $\checkmark$ & $\checkmark$ & $\checkmark$ & $\checkmark$ & & $\checkmark$ \\
\hline
\end{tabular}

Fonte: o autor (2016) 
A tabela 2 da página 141 demonstra a heterogeneidade das características observadas nos voluntários, o que possibilitou a compilação dos dados de forma a identificar a ausência de distorções relacionadas às habilidades cognitivas que estas características possam representar.

O pesquisador instruiu cada voluntário a caminhar até a porta da biblioteca do Centro Cultural e, caso se sentisse inseguro, enfrentasse algum problema ou tivesse dúvidas, bastaria parar e levantar qualquer uma das mãos para o pronto atendimento. Foi sugerido a cada voluntário que não aceitasse auxílio de outras pessoas. Os funcionários do Metrô e do Centro Cultural já estavam comunicados da pesquisa, e não interfeririam na observação.

As observações foram realizadas entre os dias 14 de julho e 5 de agosto de 2016, e foram registradas por filmadoras em posse do pesquisador e de seus auxiliares. Quando os voluntários participaram da pesquisa no mesmo dia, foram observados em horários diferentes, para evitar interferências entre eles. As filmagens resultantes foram transcritas, de acordo com Jordan e Persson (2007, p. 104), possibilitando a classificação das ações dos voluntários em cada situação informada pela audionavegação e a comparação das ações realizadas entre os voluntários. A classificação também possibilitou a análise de peculiaridades em algumas circunstâncias durante os trajetos, circunstâncias essas relacionadas à audiodescrição, às especificidades dos elementos existentes nos espaços públicos utilizados e às interferências provindas de outras pessoas que faziam uso dos espaços. 


\section{RESULTADOS}

\subsection{PESQUISAS PRELIMINARES: ENTREVISTAS COM PESSOAS COM DEFICIÊNCIA VISUAL}

As entrevistas com os convidados da ADEVA possibilitaram a obtenção de diretrizes para a elaboração de construções verbais a serem incorporadas à interface de testes que foi utilizada nas experiências posteriores. A análise qualitativa das respostas da entrevista, mostradas no apêndice "B", página 195, possibilitou a confecção da tabela 3:

Tabela 3 - Opinião dos voluntários sobre o conteúdo da interface vocal

\begin{tabular}{|c|c|c|c|c|c|c|c|}
\hline Perguntas & Padrão & RB & MC & MK & MI & CF & SE \\
\hline $1^{\mathrm{a}}$ & $\begin{array}{l}\text { Informar a } \\
\text { direção. }\end{array}$ & $\checkmark$ & $\checkmark$ & $\checkmark$ & $\checkmark$ & $\checkmark$ & $\checkmark$ \\
\hline $2^{\mathrm{a}}$ & $\begin{array}{l}\text { Não usar } \\
\text { diagonais. }\end{array}$ & $\checkmark$ & $\checkmark$ & $\checkmark$ & $\checkmark$ & $\checkmark$ & $\checkmark$ \\
\hline $3^{\underline{a}}$ & $\begin{array}{l}\text { Somente } \\
\text { descrever } \\
\text { quando não é } \\
\text { piso tátil. }\end{array}$ & $\checkmark$ & $\checkmark$ & $\begin{array}{l}\text { Nunca } \\
\text { descrever } \\
\text { linha-guia. }\end{array}$ & $\checkmark$ & $\checkmark$ & $\checkmark$ \\
\hline $4^{\underline{a}}$ & $\begin{array}{l}\text { Não mensurar } \\
\text { longas } \\
\text { distâncias } \\
\text { Passos para } \\
\text { pequenas } \\
\text { distâncias. }\end{array}$ & $\checkmark$ & $\checkmark$ & $\begin{array}{l}\quad \checkmark \\
\text { (Mais: } \\
\text { Nunca dizer } \\
\text { distâncias, } \\
\text { somente } \\
\text { direções.) }\end{array}$ & $\begin{array}{l}\quad \checkmark \\
\text { (Mais: } \\
\text { Pequenas } \\
\text { distâncias, } \\
\text { prever o } \\
\text { tamanho da } \\
\text { bengala). }\end{array}$ & $\begin{array}{l}\text { Informar } \\
\text { sobre } \\
\text { longas } \\
\text { distâncias. } \\
\text { Não } \\
\text { informar } \\
\text { pequenas } \\
\text { distâncias. }\end{array}$ & $\begin{array}{l}\text { Não } \\
\text { informar } \\
\text { grandes } \\
\text { distâncias. } \\
\text { Pequenas } \\
\text { distâncias, } \\
\text { somente } \\
\text { indicar a } \\
\text { direção. }\end{array}$ \\
\hline $5^{\underline{a}}$ & $\begin{array}{l}\text { Não citar } \\
\text { tempo. Não } \\
\text { nomear o } \\
\text { destino. }\end{array}$ & $\checkmark$ & $\checkmark$ & $\checkmark$ & $\checkmark$ & $\checkmark$ & $\checkmark$ \\
\hline $6^{\mathrm{a}}$ & $\begin{array}{l}\text { Somente } \\
\text { descrever o } \\
\text { obstáculo }\end{array}$ & $\checkmark$ & $\checkmark$ & $\checkmark$ & $\checkmark$ & $\checkmark$ & $\begin{array}{l}\quad \checkmark \\
\text { (Mais: o } \\
\text { cão-guia faz } \\
\text { o desvio.) }\end{array}$ \\
\hline $7 \underline{a}$ & $\begin{array}{l}\text { Descrever o } \\
\text { objeto. }\end{array}$ & $\checkmark$ & $\checkmark$ & $\checkmark$ & $\checkmark$ & $\checkmark$ & $\checkmark$ \\
\hline $8^{\underline{a}}$ & $\begin{array}{l}\text { Informar riscos. } \\
\text { Informar } \\
\text { impedimentos. } \\
\text { Não descrever. }\end{array}$ & $\checkmark$ & $\checkmark$ & $\checkmark$ & $\checkmark$ & $\checkmark$ & $\begin{array}{l}\text { Descrever, } \\
\text { mas o cão- } \\
\text { guia faz o } \\
\text { desvio. }\end{array}$ \\
\hline 9a & $\begin{array}{l}\text { Informar a } \\
\text { possibilidade } \\
\text { de acidente. }\end{array}$ & $\checkmark$ & $\checkmark$ & $\checkmark$ & $\checkmark$ & $\checkmark$ & $\begin{array}{l}\quad \checkmark \\
\text { (Mais: o } \\
\text { cão-guia faz } \\
\text { o desvio.) }\end{array}$ \\
\hline
\end{tabular}


Durante a execução das entrevistas observou-se que as respostas seguiram o mesmo padrão desde o início, com poucas diferenças de conteúdo, atingindo-se a saturação dos dados (FLICK, 2009, p. 120; THIRY-CHERQUES, 2009) e levando à cessão das entrevistas no sexto voluntário.

As respostas obtidas às questões das entrevistas foram predominantemente semelhantes. De fato, os dois primeiros entrevistados forneceram informações com conteúdo essencialmente idêntico, e os quatro entrevistados subsequentes forneceram algumas mudanças, principalmente na quarta questão, cujas respostas assemelharam-se, mas apresentaram adicionais à resposta principal que se diferenciaram para cada voluntário.

Notou-se também que o entrevistado "SE", por utilizar cão-guia, tem preferências ligeiramente diferentes quanto a informar a presença de obstáculos e riscos, pois o cão guia o protege de situações onde existem riscos de queda ou de colisão com objetos, realizando um desvio ou bloqueando sua passagem. No entanto, citou que o cão não possui a capacidade de informar o motivo do desvio, e por isso considera ser importante que um sistema de audionavegação descreva os obstáculos e as situações de risco e de perigos.

Com base nos dados obtidos, observa-se que as maiores discrepâncias de opiniões nos entrevistados residem no modo de informar distâncias, pois a maioria não faz uso de distâncias por unidades em metros, tampouco por passos. A entrevistada "CE" citou que, ao receber informações de distância em metros ou passos, realiza uma correlação abstrata de longe ou perto: muitos passos são equivalentes a longe, e poucos passos significam perto. Devido às respostas a esta quarta pergunta terem sido divididas, posto que três dos seis entrevistados citaram não ser desejável a informação de medidas de distâncias, uma informação com este conceito foi incorporada à interface eletrônica de audionavegação, para que pudesse ser observada a percepção dos voluntários durante o experimento em ambiente controlado.

De acordo com a opinião dos entrevistados, quando a distância é pequena, é esperado que a audionavegação somente fornecesse a direção, suprimindo-se quaisquer unidades, sejam elas metros ou passos. A entrevistada "MI" também 
citou a importância de se prever o tamanho da bengala quando informar pequenas distâncias, lembrando que "a bengala é uma extensão do corpo da pessoa com deficiência visual”.

As respostas às questões pragmáticas foram bem diretas e precisas, demandando de menor tempo de reflexão para serem respondidas, e seu conteúdo foi mais relacionado a informações direcionais. Já as respostas mais abstratas demandaram de maior tempo de reflexão para serem respondidas pelos entrevistados, pois quanto mais abstrata foi a questão, maior quantidade de possibilidades para descrevê-la, e seu conteúdo apresentou respostas mais informativas e descritivas.

Os preceitos de indicações e de descrição ambiental obtidos com estas entrevistas foram utilizados para a elaboração das construções verbais para incorporação na interface eletrônica de testes, possibilitando a execução das observações práticas, tanto na pesquisa preliminar em ambiente fechado quanto na pesquisa em ambientes públicos.

\subsection{PESQUISAS PRELIMINARES: EXPERIMENTO PRÁTICO EM LOCAL CONTROLADO}

A elaboração das construções verbais para este primeiro experimento prático considerou os preceitos obtidos por meio dos resultados das entrevistas preliminares, e foram incorporadas à interface de testes, embutida em um smartphone, que forneceu a audionavegação aos voluntários cedidos pela ADEVA, sendo então disponibilizados os equipamentos que forneceriam a audionavegação para que os voluntários pudessem escolher e utilizar durante as observações.

No primeiro dia, ambos os convidados, "MI" e "MA", experimentaram a utilização do fone de condução óssea, por curiosidade quanto a este tipo de aparelho, considerado ainda uma novidade no Brasil. No entanto, a partir do segundo dia de experimentação, estes mesmos convidados recusaram a utilização do fone de condução óssea, preferindo, respectivamente, headphones e a viva-voz, indicando que os fones de condução óssea e os earphones não foram preferência para os convidados. Considerando-se que a escolha do fone de condução óssea no primeiro 
dia foi feita com base na curiosidade, não se repetindo dias subsequentes, foram analisadas somente as escolhas realizadas no segundo e no terceiro dia.

Os convidados "RE" e "CE", que participaram no segundo e terceiro dia, recusaram o uso de fones de quaisquer tipos, preferindo a viva-voz. Observou-se também que a utilização da viva-voz sofreu leve diferenciação, pois os convidados "MA" e "CE" posicionaram o smartphone no ouvido de forma constante, enquanto "RE" somente aproximava smartphone do ouvido quando sentia a vibração háptica de aviso de mensagem. Durante a entrevista, "MA" relatou ter o costume de caminhar utilizando-se de smartphone para realizar ligações, sem utilizar fones. Os outros três convidados informaram não utilizar smartphones enquanto estão caminhando, devido ao receio de serem assaltados e para manterem uma das mãos livres (quadro 12).

Quadro 12 - Escolhas dos convidados sobre os recursos de audio do experimento

\begin{tabular}{rllll}
\hline & \multicolumn{4}{c}{ Convidados } \\
\cline { 2 - 5 } & MI & MA & RE & CE \\
\hline Recurso Sonoro & Fone & Viva-voz & Viva-voz & Viva-voz \\
\hline Posição do & \multirow{2}{*}{ Bolso } & Mão (ouvido & Mão & Mão \\
smartphone & & constantemente) & $\begin{array}{l}\text { quando } \\
\text { necessário) }\end{array}$ & (ouvido só \\
& & & quando \\
& & & necessário) \\
\hline
\end{tabular}

Fonte: do autor, com base nos dados da pesquisa (2016)

Questionados se utilizavam smartphones com fones de ouvido em locais públicos, os voluntários informaram as escolhas mostradas no quadro 13:

Quadro 13 - Respostas dos voluntários sobre utilizar eletrônicos em locais públicos

\begin{tabular}{rllll}
\hline & \multicolumn{4}{c}{ Convidados } \\
\cline { 2 - 5 } & MI & MA & RE & CE \\
\hline $\begin{array}{r}\text { Utilizaria smartphone } \\
\text { em locais públicos? }\end{array}$ & Não & Sim & Não & Não \\
\hline $\begin{array}{r}\text { Utiliza fones de ouvido } \\
\text { em locais públicos? }\end{array}$ & Sim & Não & Não & Não \\
\hline
\end{tabular}

Fonte: o autor (2016) 
Perguntado à voluntária "MI" sobre o uso de fones de ouvido em locais públicos, pois informou não fazer uso de smartphone, "MI" respondeu que utiliza aparelho de som portátil para ouvir música e rádio.

Mesmo com as desvantagens observadas com o uso da viva-voz, relacionadas à necessidade de manter o smartphone na mão além do som poder ser ouvido por outras pessoas ao redor, notou-se que a utilização de fones de qualquer tipo não foi bem recebida pelos convidados. Nos comentários após cada acompanhamento, todos os convidados relataram que a utilização de fones é desconfortável e incômoda. "MI" citou que parte deste incômodo se deve aos fios de conexão, presentes nos três tipos de fones, complementando a informação ao dizer que fones sem fio seriam mais bem aceitos. No entanto, a opção de uso de fones sem fio não foi confirmada com os outros convidados, que negaram diferenciar fones com e sem fio, citando que o incômodo existe devido ao posicionamento do fone, fixo nos ouvidos ou na cabeça, independentemente da existência de fios.

A especialista "CM" citou que as pessoas com deficiência visual total valorizam as informações sonoras e vocais, avaliando que este foi o motivo dos convidados "MA" e "CE" manterem o smartphone no ouvido, contrariando o treinamento de orientação e mobilidade que instrui as pessoas com deficiência visual a conservar livre, por motivo de segurança, a mão que não está segurando a bengala longa. "CM" também comentou que as pessoas com deficiência visual, usuárias de smartphones ou outros aparelhos sonoros, procuram fazer uso de fones de ouvido, citando como exemplo seu marido, que tem deficiência visual total e frequentemente caminha na rua usando fones do tipo earphones. Devido às observações conflitantes com as recomendações da especialista, este item tornouse um dos focos de observação para a pesquisa em locais públicos.

Quanto à funcionalidade do alerta sonoro prévio às mensagens, observou-se que os convidados compreenderam sua funcionalidade de forma imediata. As observações também indicaram que o tempo de um segundo entre o início do alerta e o início da fala demonstrou-se adequado, fornecendo um intervalo de tempo para que o convidado possa dispender atenção à mensagem que viria a seguir. Ao serem incentivados a dar sugestões sobre a melodia prévia, os convidados informaram 
que não há necessidade de modificações em suas características. Como aspecto importante, observou-se que houve uma tendência de os convidados reduzirem a velocidade de seus passos no momento em que a melodia era ouvida.

Todos os convidados demonstraram compreender corretamente as instruções de voz, conforme chegavam aos locais os quais as instruções se referiam. Durante as observações, os aplicativos e gêneros de voz foram trocados constantemente, e todos os convidados experimentaram as opções disponíveis. Não foram percebidas diferenças de cognição dos convidados durante o uso das diferentes vozes. Nos comentários posteriores, todos os convidados informaram ter experiência com voz sintetizada, de tipos e gêneros diferentes, pois utilizam sistemas de leitura de textos em computadores. Os convidados afirmaram que não fazem distinção de preferência entre gêneros de vozes digitais, mas consideram importante que a voz digital realize uma sintetização mais próxima possível da voz humana verdadeira. Por este motivo, os convidados consideraram que o aplicativo "síntese de Voz do Google" realça a sensação de estar ouvindo uma máquina, sendo unânimes na preferência pelo aplicativo SVOX Luciana TTS, pois, segundo eles, o SVOX simula muito bem a fala humana. A convidada "MI" comentou que sua preferência pela voz gerada pelo SVOX Luciana TTS é devido à sua percepção de ser mais aproximada da voz humana natural, tornando-se, portanto, mais agradável. "MI" disse que algumas vezes as vozes sintetizadas são irritantes, pois o ritmo e compasso da fala parecem muito artificiais.

0 ponto notável das observações foram os conteúdos verbais das vozes sintetizadas. Todos os convidados realizaram comentários quanto aos conteúdos verbais. A convidada "MI" destacou a frase dita no item "b" (porta à direita), pois a porta estava, de fato, à fronte-direita da convidada. "MI" disse que, apesar da localização da porta não ser exatamente à sua direita, a informação não é incorreta, pois considera que a bengala longa é uma extensão háptica de seu braço, utilizando-a para buscar os batentes da porta. Nota-se, então, que qualquer informação sobre objetos ou locais próximos precisa considerar o alcance da bengala longa, não somente o corpo da pessoa. 
As frases utilizadas nas falas "g" e " $k$ ", que instruíam a utilizar a parede como linha guia, também receberam comentários. 0 convidado "MA" disse que não tem o costume de caminhar próximo a paredes, sentindo-se incomodado ao perceber que a linha guia era a parede do pátio. Em contrapartida, a convidada "MI" disse que utiliza constantemente paredes e muros nos espaços públicos como linha guia. Os convidados "RE" e "CE" não se pronunciaram quanto a estas frases, mas observouse que compreenderam facilmente que a parede era a linha guia.

A frase utilizada nos itens "f" e "i" ("siga em frente por vinte passos") também produziu resultados importantes: todos os convidados informaram que não é adequado utilizar contagem de passos como métrica. Esta discrepância já foi notada durante a observação da experiência, pois cada convidado teve comportamento peculiar ao receber esta instrução, e concordou com as opiniões dos convidados que participaram da entrevista preliminar, conforme resultados mostrados no capítulo 4.1, página 143.

O convidado "MA", no momento que ouviu a instrução, parou de caminhar e imediatamente disse que haveria problemas com a contagem de passos, seguindo o trajeto logo em seguida.

A convidada "MI" atingiu os vinte passos antes de chegarem ao local onde receberia a próxima informação, demonstrando dúvidas ao reduzir sua velocidade, mas seguiu caminhando em baixa velocidade até receber a próxima informação, logo à frente.

Os convidados "CE", "MA" e "RE" atingiram a contagem antes que a próxima informação fosse disponibilizada. Neste momento, "MA" e "RE" cessaram sua caminhada, precisando ser instruídos pelo pesquisador a continuarem até a próxima mensagem.

Em contrapartida, a convidada "CE" manteve-se caminhando mesmo após ter atingido os vinte passos. Ao ser questionada posteriormente sobre sua ação neste caso em particular, "CE" disse que não contou passos enquanto estava seguindo a indicação, simplesmente seguiu em frente, pois informou que considera medidas 
que indicam longas distâncias, como a instrução "vinte passos", são sinônimos de "longa distância".

Estas informações podem ser mais bem visualizadas no quadro 14.

Quadro 14 - Reconhecimento das instruções “f”e "i" (siga por 20 passos)

\begin{tabular}{|c|c|c|c|c|}
\hline & \multicolumn{4}{|c|}{ Convidados } \\
\hline & MI & MA & RE & $\mathbf{C E}$ \\
\hline Ação realizada & $\begin{array}{l}\text { Contou os } \\
\text { passos. }\end{array}$ & $\begin{array}{l}\text { Contou os } \\
\text { passos, mas } \\
\text { informou } \\
\text { imediatamente } \\
\text { que não } \\
\text { concorda. }\end{array}$ & $\begin{array}{l}\text { Contou os } \\
\text { passos. }\end{array}$ & $\begin{array}{l}\text { Desconsiderou } \\
\text { a métrica. }\end{array}$ \\
\hline $\begin{array}{r}\text { Ao atingir } 20 \\
\text { passos }\end{array}$ & $\begin{array}{l}\text { Parou antes do } \\
\text { local. }\end{array}$ & $\begin{array}{l}\text { Parou antes do } \\
\text { local. }\end{array}$ & $\begin{array}{l}\text { Parou antes do } \\
\text { local. }\end{array}$ & $\begin{array}{l}\text { Continuou } \\
\text { caminhando. }\end{array}$ \\
\hline $\begin{array}{r}\text { Opinião posterior } \\
\text { (depoimento) }\end{array}$ & $\begin{array}{l}\text { "Passos" não é } \\
\text { adequada. }\end{array}$ & $\begin{array}{l}\text { "Passos" não é } \\
\text { adequada. }\end{array}$ & $\begin{array}{l}\text { "Passos" não é } \\
\text { adequada. }\end{array}$ & $\begin{array}{l}\text { Considerou } \\
\text { como longa } \\
\text { distância. }\end{array}$ \\
\hline
\end{tabular}

Fonte: do autor (2016)

A especialista "CM", durante a entrevista, comentou não ser comum utilizar "passos" como medida de distância, afirmando que, em situações específicas, é comum utilizar-se metros, pois cada pessoa tende a se acostumar com o tamanho de seu próprio passo, formando uma associação individual entre passos e metros. Lembrou que existem situações que utilizam "passos" como métrica, mas somente se as distâncias envolvidas forem curtas, para até três passos. "CM" também comentou que até mesmo a utilização de "metros" não é comum, pois raramente as pessoas contam passos quando caminham por longas distâncias. Nestes casos, "CM" informou que as pessoas com deficiência visual utilizam referências táteis, sonoras e até mesmo olfativas quando as distâncias são longas. Caso seja necessário usar termos para longas distâncias, é preferível utilizar termos abstratos e relativos, conforme observado no experimento e no depoimento da convidada "CE".

Uma situação notável ocorreu no terceiro trajeto, durante a caminhada da convidada "CE": ao se aproximar do final do corredor oeste, que termina em uma parede perpendicular, "CE" diminuiu o passo antes mesmo de receber a informação para retornar, dita pela frase "j". Lembrando que "CE" tem deficiência visual total, foi questionada sobre esta ação, e respondeu que percebeu que estava 
se aproximando de uma parede porque sentiu o obstáculo, como se fosse uma "sombra". A especialista "CM" comentou o caso, afirmando conhecer este fenômeno por meio de sua experiência ao ministrar o curso de orientação e mobilidade, pois alguns alunos com deficiência visual total percebem que estão próximos de paredes, esquinas e corredores estreitos. "CM" informou que esta peculiaridade da percepção das pessoas com deficiência visual tem relação com o eco sonoro refletido por obstáculos de grande porte. É o fenômeno da "sombra sonora" citada por Machado et al. (2003) e Mariani (2016, p. 53). Este fenômeno não foi identificado na observação dos outros três convidados.

As informações colhidas no experimento na ADEVA, juntamente dos resultados das entrevistas, foram utilizadas na preparação das construções verbais, na preparação dos ambientes, na execução e na análise dos dados da experiência de audionavegação em ambientes públicos, cujos resultados seguem no capítulo 4.3, página 152. 


\subsection{PESQUISA PRINCIPAL: EXPERIMENTOS DE AUDIONAVEGAÇÃO EM ESPAÇOS PÚBLICOS}

Durante as observações dos voluntários utilizando audionavegação ao caminharem pelos ambientes públicos, foram percebidas algumas características gerais e algumas características específicas que estão relacionadas à condição do voluntário, da forma de uso dos recursos de acessibilidade ou relacionadas a situações momentâneas presentes nos ambientes.

Primeiramente foi mostrado a cada voluntário o volume sonoro da viva-voz do smartphone, e todos os voluntários concluíram que o volume não seria suficiente devido ao ruído presente nos ambientes públicos, sendo necessário utilizar algum tipo de fone de ouvido. Assim, três dos voluntários escolheram utilizar o headphone: o voluntário "IC", “MR" e "RB” (foto 8, página 138, a centro). Os outros quatro perguntaram se não poderiam utilizar seus próprios fones de ouvido, e foram autorizados a colocá-lo. Os fones de ouvido dos voluntários são do tipo earphone, mas, ao contrário do earphone disponibilizado (foto 8 , página 138, à esquerda), os fones dos voluntários possuíam fios, semelhantes ao da foto 9.

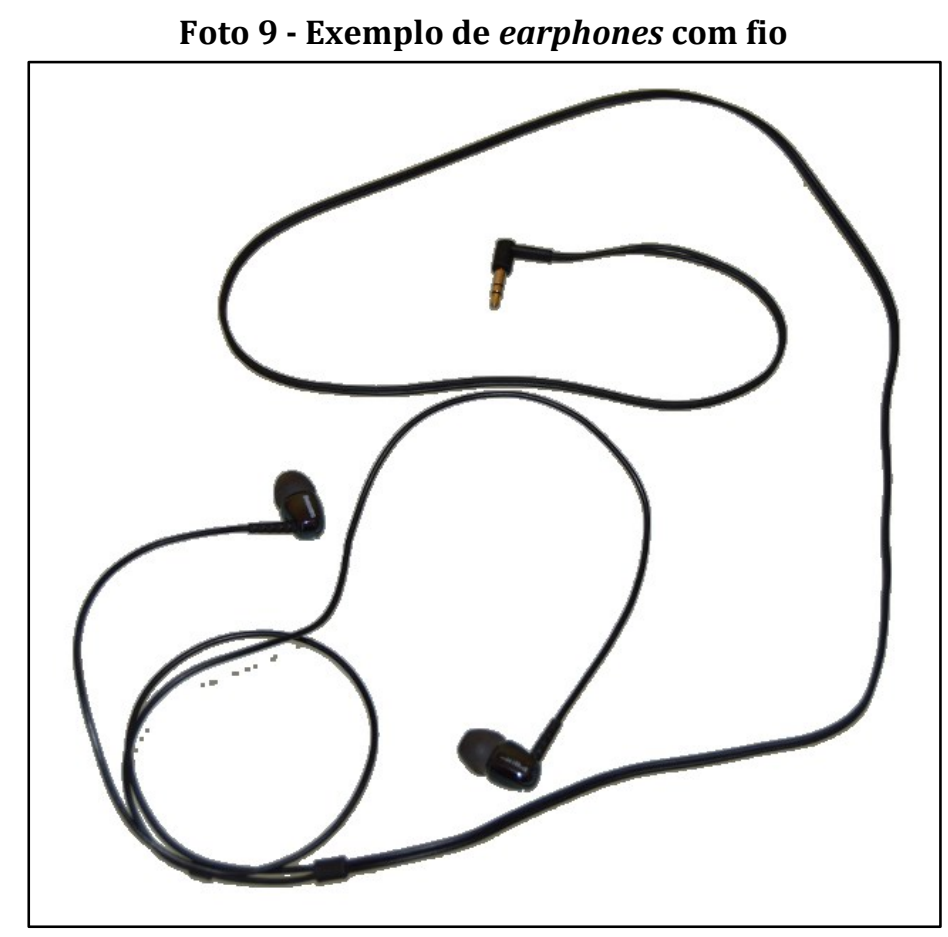

Fonte: do autor (2016) 
Ao serem questionados de sua escolha, os voluntários "IC", "MR", e "RB" informaram ter gostado do headphone por ser confortável, pois não precisa ser colocado dentro dos ouvidos e possuir espuma que possibilita continuar ouvindo o ambiente. Os voluntários "DA", "EB", "RC" e "SE" informaram que usariam seus próprios fones porque já estavam acostumados. Estas informações podem ser mais bem vistas no quadro 15.

\section{Quadro 15 - Escolhas das ferramentas para audição da audionavegação}

\begin{tabular}{llll}
\hline & & Escolha & Motivo \\
\hline & DA & Earphone (próprio) & Está acostumado \\
\cline { 2 - 4 } & EB & Earphone (próprio) & Está acostumado \\
\cline { 2 - 4 } & IC & Headphone & É confortável \\
\cline { 2 - 4 } & MR & Headphone & É confortável \\
\cline { 2 - 4 } & RB & Headphone & É confortável \\
\hline RC & Earphone (próprio) & Está acostumado \\
\hline & SE & Earphone (próprio) & Está acostumado \\
\hline
\end{tabular}

Fonte: do autor (2016)

Portanto, sobre a preferência dos voluntários acerca do tipo de ferramenta para audição das instruções, quatro preferiram utilizar seus fones habituais, e três escolheram utilizar o headphone sem fio por conta da percepção de conforto. Nenhum voluntário de dispôs a usar fones de condução óssea.

Enquanto colocavam os fones de ouvido, os voluntários foram questionados se possuem o costume utiliza-los enquanto caminham. Todos, inclusive "IC", "MR" e "RB", informaram que utilizam o earphone com fio. Questionados sobre a possibilidade de os fones dificultarem a audição dos sons ambientes, todos informaram que não utilizam constantemente os fones, somente em caso de ligações telefônicas ou para ouvirem música enquanto estão parados, e mesmo assim utilizam os fones somente em um ouvido, deixando o outro livre para ouvirem o ambiente.

Durante o trajeto, os voluntários "IC" e "MR", utilizando headphones, foram abordados no interior da estação por pessoas que ofereceram ajuda. Em ambos os casos os voluntários responderam imediatamente a quem ofereceu auxílio, não demonstrando dificuldade para ouvir a oferta de ajuda, mesmo estando utilizando headphones em ambos os ouvidos. No caso da voluntária "IC", a pessoa que 
ofereceu auxílio a abordou tocando seu braço e iniciando um diálogo no exato momento que o equipamento estava realizando uma instrução. A voluntária não teve dificuldade de ouvir a outra pessoa, mas teve dificuldade de compreender a instrução da audionavegação. As voluntárias "DA" e "RC" também foram abordadas por pessoas oferecendo ajuda, e não tiveram dificuldades em compreender o que as pessoas estavam dizendo. Inclusive a voluntária "DA" manteve um rápido diálogo com uma pessoa que lhe ofereceu auxílio e, à semelhança do ocorrido com a voluntária "IC", a interrupção do trajeto por outra pessoa dificultou a compreensão das instruções pela voluntária.

No primeiro acompanhamento, realizado no dia 14 de julho de 2017, o voluntário "RB" iniciou o trajeto voltado à parede da plataforma, como se estivesse saindo do trem. Ao receber a instrução da audionavegação, virou à sua direita e seguiu pelo piso tátil até o momento em que a audionavegação forneceu a primeira informação de escolha, entre seguir pelo piso tátil até o elevador ou deixar o piso tátil, virar à sua esquerda e subir pelas escadas. Neste momento, "RB" preferiu utilizar as escadas (foto 10), saindo do piso tátil e se dirigindo a elas.

Foto 10 - Voluntário “RB”, mensagem “Esquerda, escadas. Frente, elevador.”

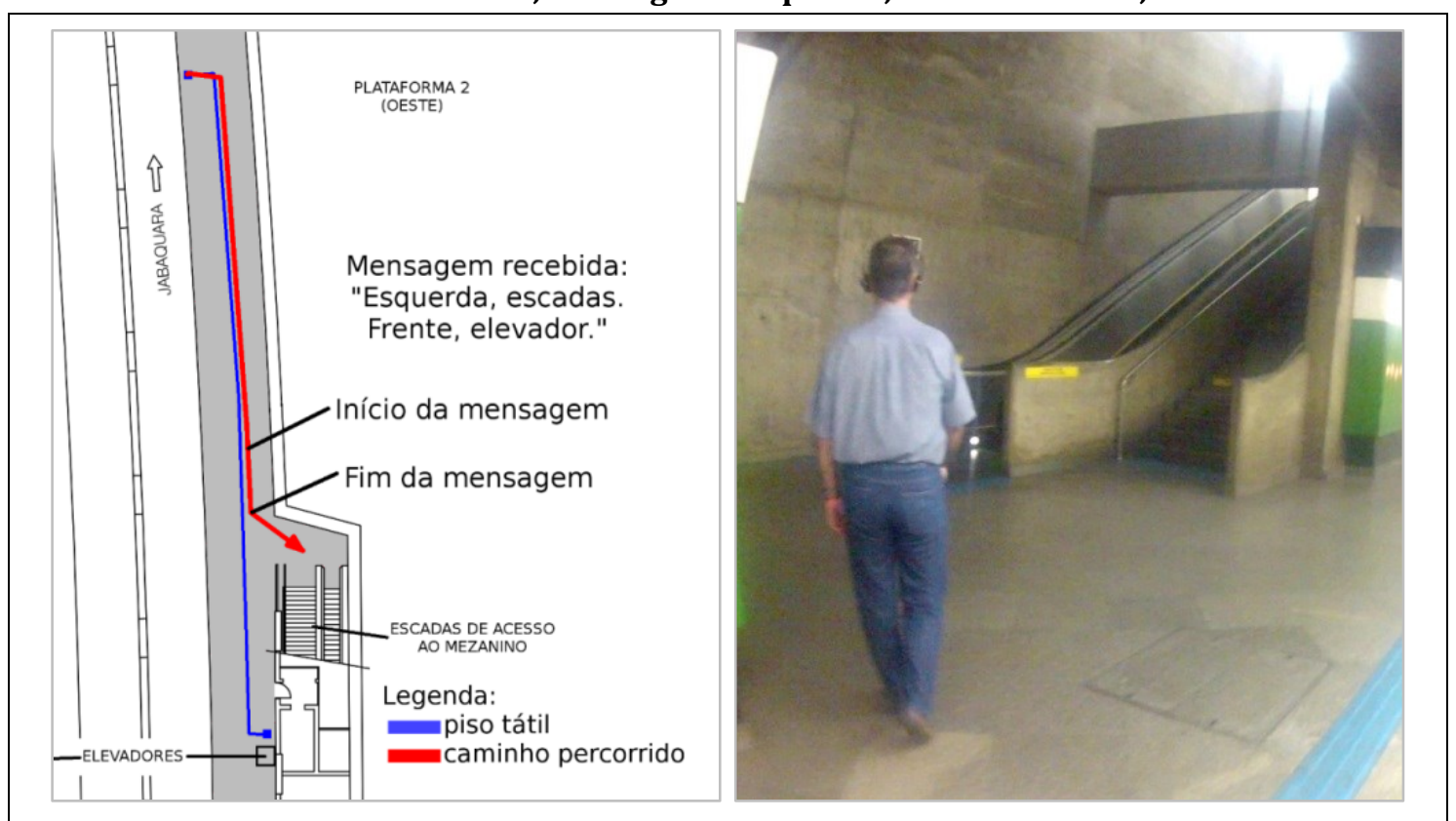

Fonte: o autor (2016) 
A ação do voluntário "RB" de deixar o piso tátil e seguir para as escadas foi considerada inicialmente como uma preferência pessoal, pois "RB" não possui treinamento de orientação e mobilidade, mas é autônomo para caminhar em locais públicos. No entanto, no decorrer das observações, todos os voluntários agiram da mesma forma, preferindo seguir para as escadas mesmo sem a existência de piso tátil no local.

Apesar de todos escolherem seguir para as escadas, a escolha de qual tipo de escada usar, seja escada fixa ou escada rolante, variou de voluntário para voluntário, inclusive mudando de escolha quando se compara a seleção da escada da plataforma com a seleção da escada do acesso oeste. As descrições das escadas pela audionavegação não foi aleatória, seguiu a ordem da mais próxima à mais distante do voluntário. As escolhas de cada voluntário são vistas no quadro 16.

Quadro 16 - Escolha do tipo de escada por cada voluntário

\begin{tabular}{llll}
\hline & & $\begin{array}{l}\text { Escadas } \\
\text { Plataforma } \Rightarrow \text { Mezanino }\end{array}$ & $\begin{array}{l}\text { Escadas } \\
\text { Mezanino } \Rightarrow \text { Acesso Oeste }\end{array}$ \\
\hline & DA & Fixa & Fixa central \\
\cline { 2 - 4 } & EB & Rolante & Fixa central \\
\cline { 2 - 4 } & IC & Rolante & Fixa central \\
\cline { 2 - 4 } & MR & Fixa & Rolante \\
\cline { 2 - 4 } & RB & Fixa & Rolante \\
\cline { 2 - 4 } & RC & Fixa & Rolante \\
\hline & \multicolumn{2}{c}{ SE } & Rolante* voluntário “SE” usa cão-guia, e foi o cão quem escolheu as escadas rolantes. \\
& & Fonte: do autor (2016)
\end{tabular}

As escolhas dos voluntários foram equilibradas, a presença do piso tátil aparentemente não influenciou na compreensão da audionavegação sobre a posição das escadas em ambos os pavimentos, pois a única escada que possui piso tátil, neste trajeto, é a escada fixa central do acesso oeste, que obteve a mesma quantidade de escolhas com a escada rolante, considerando que foi o cão-guia do voluntário "SE" quem escolheu a escada rolante.

Ainda sobre o acesso oeste, notou-se que nenhum voluntário buscou a primeira escada fixa, à esquerda, que era a mais distante. 
Outro evento notável, também no acesso oeste, é que a voluntária "RC", que estava utilizando o piso tátil, parou ao lado da escada rolante ao ouvir a audionavegação, buscando com a bengala alguma indicação de piso tátil que levasse à escada rolante, que não existe no local. Mesmo não encontrando, rapidamente deixou o piso tátil que leva à escada fixa, e seguiu para a escada rolante, demonstrando confiança na audionavegação. As fotos 11, 12 e 13, páginas 156 e 157, apresentam esta sequência do evento.

Foto 11 - Voluntária "RC" recebendo a instrução da existência da escada rolante

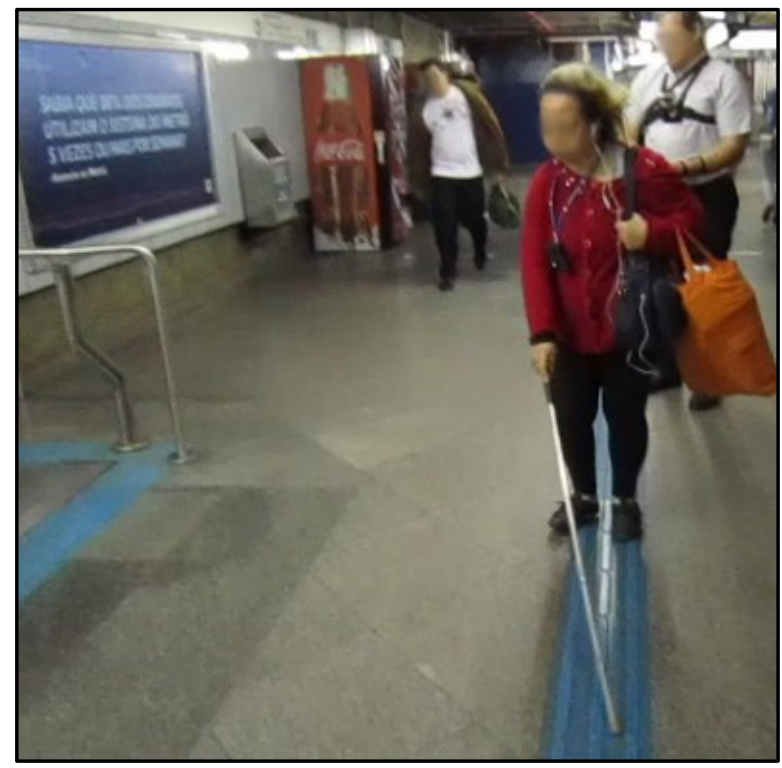

Fonte: do autor (2016)

Foto 12 - Voluntária "RC" decidindo se segue para a escada rolante sem piso tátil

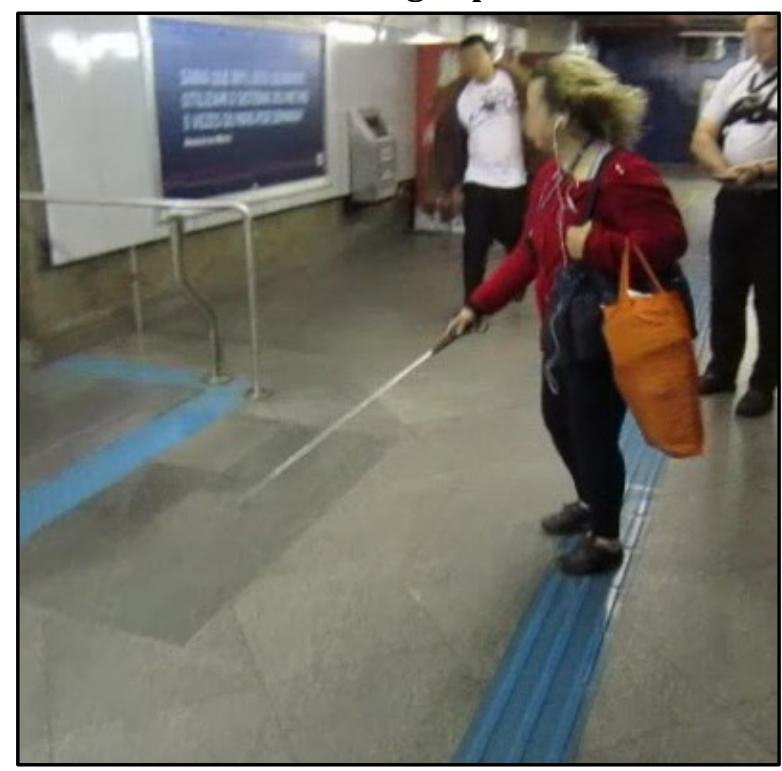

Fonte: do autor (2016) 
Foto 13 - Voluntária “RC” seguindo para a escada rolante sem piso tátil

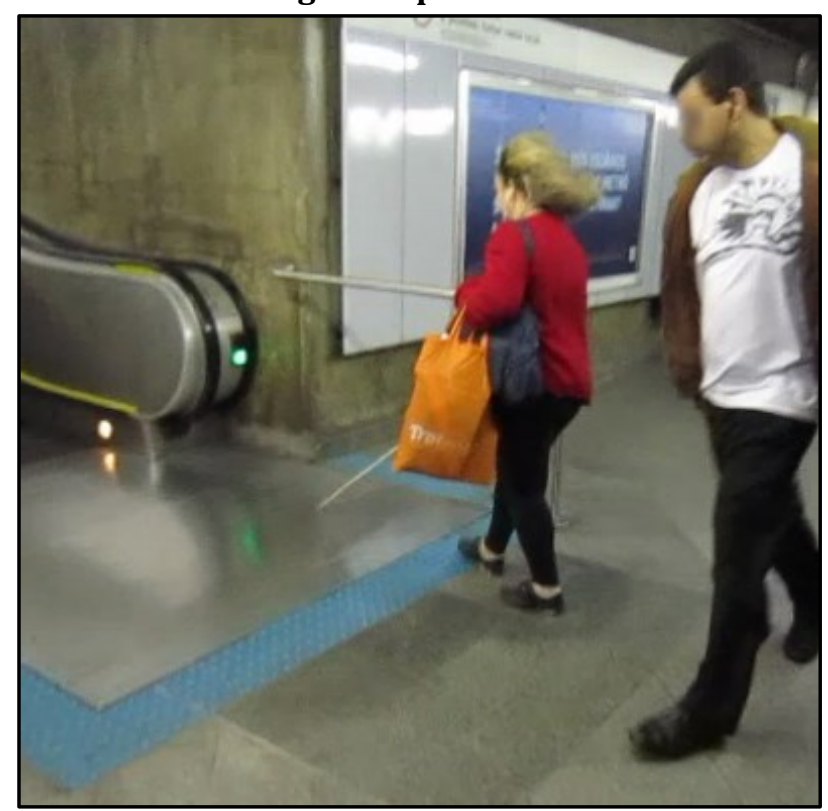

Fonte: do autor (2016)

Quando recebiam as informações que estariam aproximando-se de escadas, os voluntários adotaram uma postura característica, independente se vai seguir pela escada fixa ou rolante. Todos os voluntários que usavam a bengala passaram a segurá-la com a mão esquerda, enquanto buscavam os corrimãos com a mão direita. Constata-se, assim, um ganho de tempo e de segurança no percurso, devido à audionavegação prover um conhecimento prévio da presença de escadas. A foto 14 ilustra esta postura corporal para utilização de escadas.

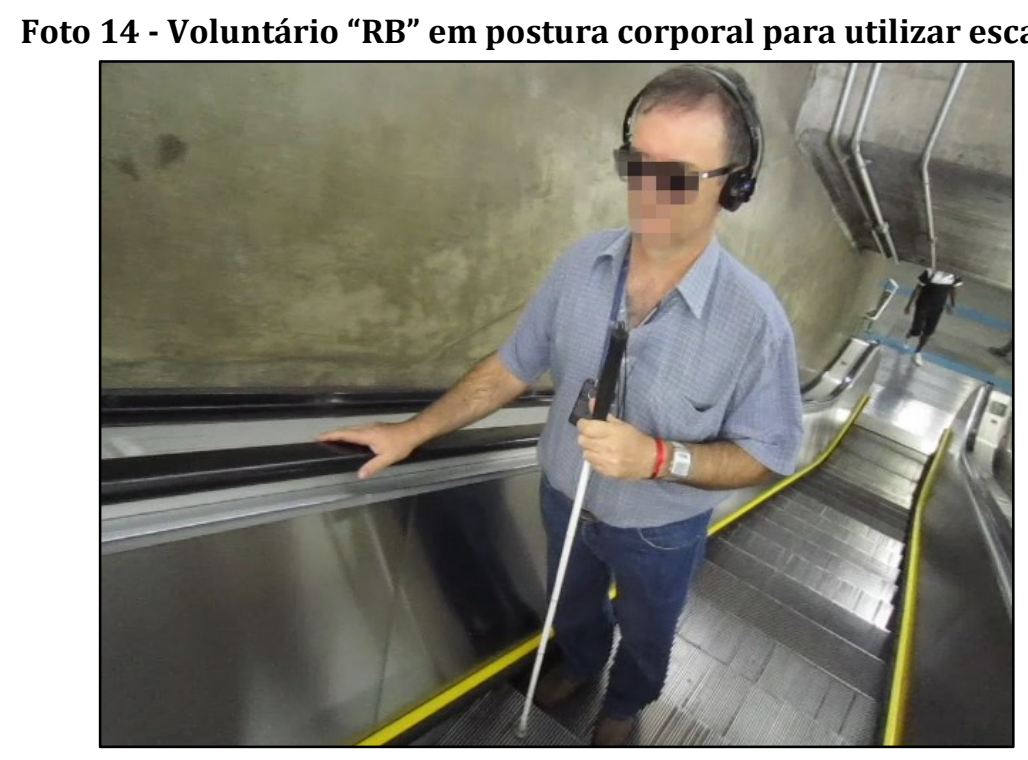

Fonte: do autor (2016) 
As frases de audiodescrição da audionavegação foram apresentadas em tempo hábil, permitindo aos voluntários ouvi-las antes de cada situação ambiental que exigisse uma decisão sobre o trajeto. A distância entre o início de cada frase e a situação ambiental foi calculada com base na velocidade média do caminhar de pessoas com deficiência visual, conforme Ribeiro et al. (2010, p. 30).

Constatou-se durante as observações que a velocidade média dos voluntários ficou adequada ao citado por Ribeiro et al., de 0,6 m/s. No entanto, quando as frases ofereciam mais de uma possibilidade de escolha, todos os voluntários agiram de forma peculiar: eles seguiram as instruções na medida em que a frase era falada, sem aguardar o final da instrução completa antes de se decidirem sua direção.

Esta peculiaridade pode ser observada em três situações:

1) quando os voluntários decidiram seguir pelas escadas da plataforma ao invés do elevador;

2) quando os voluntários precisaram decidir qual acesso de saída no mezanino;

3) na saída do acesso Oeste, logo após deixarem a escada.

Em todos estes casos os voluntários mudaram de direção antes do final das frases, seguindo na direção correta para o trajeto, mas em um momento anterior ao previsto.

Na plataforma, esta peculiaridade pôde ser observada com o voluntário "RB", que seguiu à esquerda antes do final da instrução "Esquerda, escadas. Frente, elevador". Ao ouvir a primeira parte da mensagem ("Esquerda, escadas"), RB já se voltou à esquerda, tocando com a bengala na parede, obrigando-o a corrigir sua rota (foto 15 , página 159 ). 
Foto 15 - Voluntário “RB” saindo da rota antes do tempo

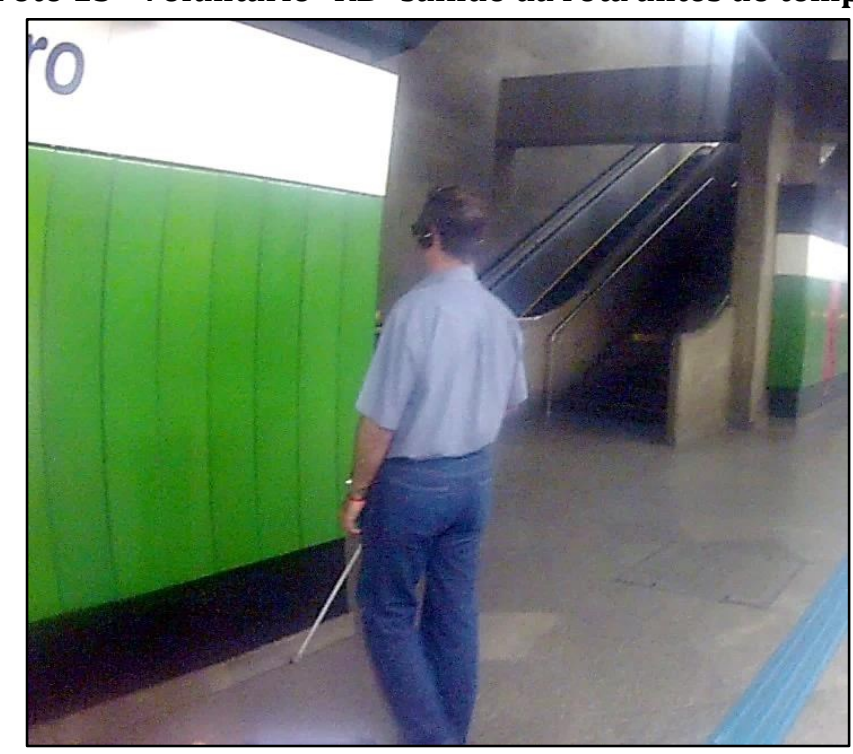

Fonte: do autor (2016)

A voluntária "IC" e o voluntário "MC" mostraram a mesma atitude no acesso Oeste, logo após saírem das escadas. Ao escolherem seguir à esquerda, para a saída ao Centro Cultural, tocaram a parede antes da saída (foto 16).

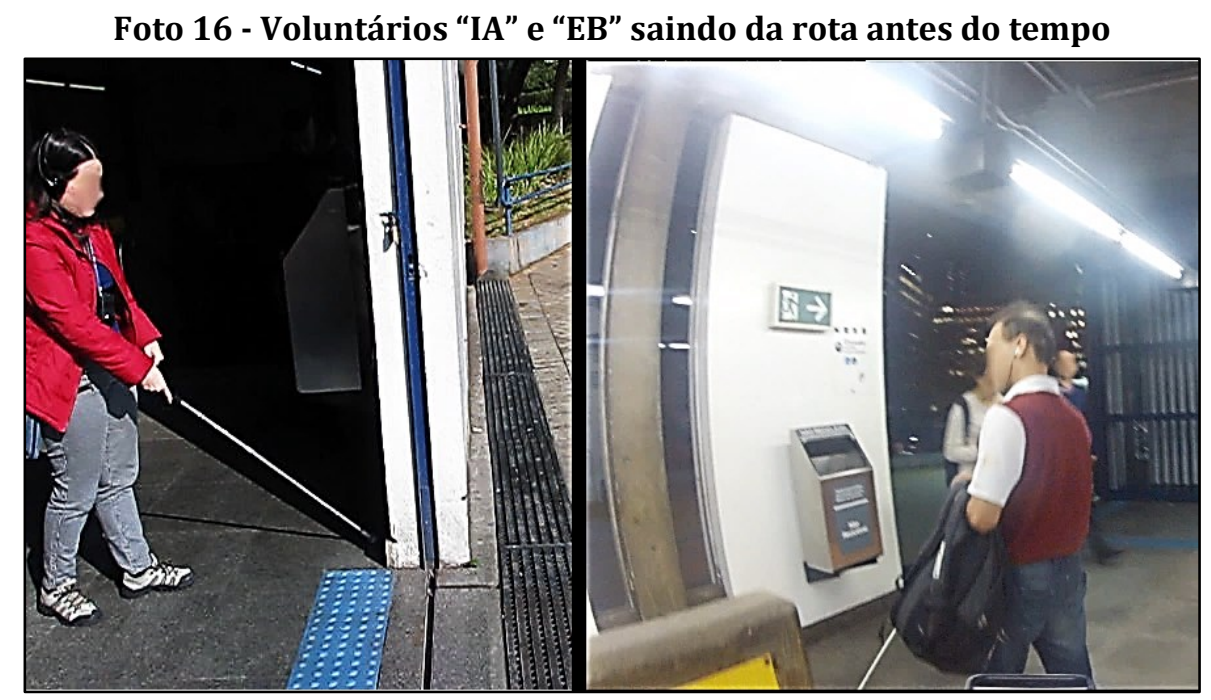

Fonte: do autor (2016)

Uma situação importante ocorreu no mezanino, fruto de uma combinação divergente de informações fornecidas aos voluntários. No local da bifurcação que leva aos acessos oeste e leste, a combinação da presença do piso tátil de alerta com a audionavegação gerou dúvidas em alguns voluntários. 
Neste local há piso tátil direcional e de alerta, que leva aos acessos. No entanto, sua disposição é mais complexa que o usual, devido a ser este um local que apresenta diversas bifurcações (foto 17).

Foto 17 - Piso tátil na bifurcação para os acessos

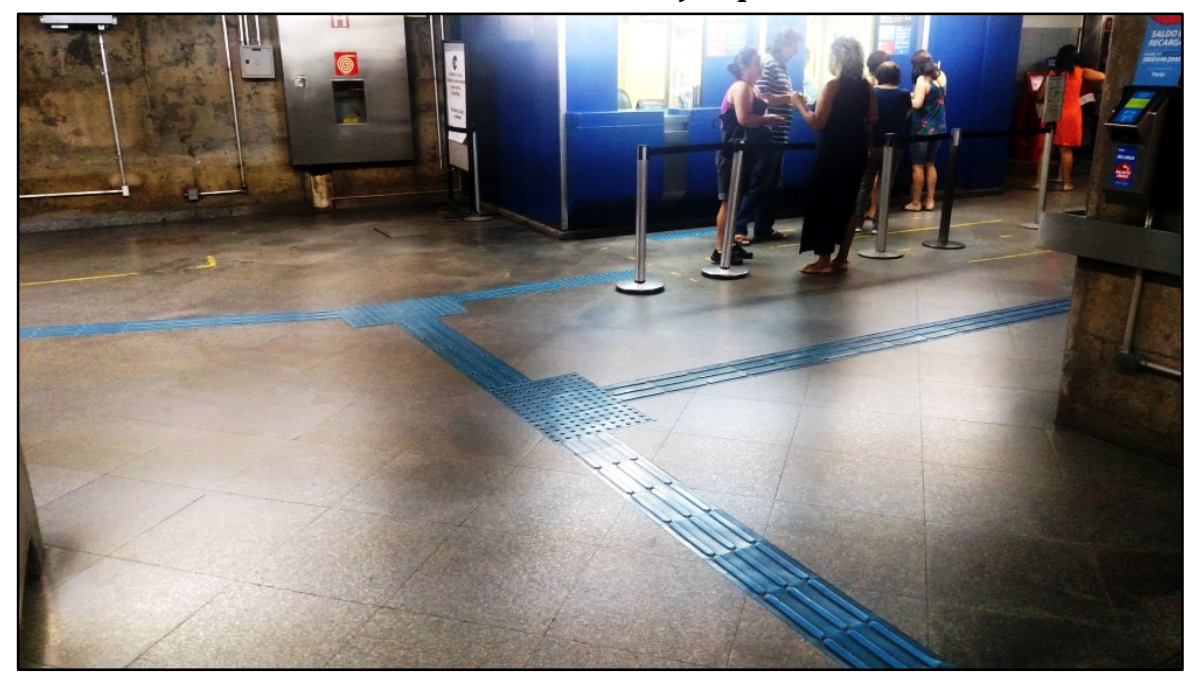

Fonte: do autor (2016)

Neste local, os voluntários deveriam escolher seguir para a esquerda. Devido ao fato do piso tátil que leva ao acesso à esquerda estar posicionado mais à frente, a sequência de instruções da audionavegação não se adequou à sinalização tátil, e alguns voluntários, como "RC", demonstraram certa dúvida e até mesmo hesitação em seguir a instrução da audionavegação (foto 18).

Foto 18 - Voluntária “RC” buscando a bifurcação esquerda após a informação por audio

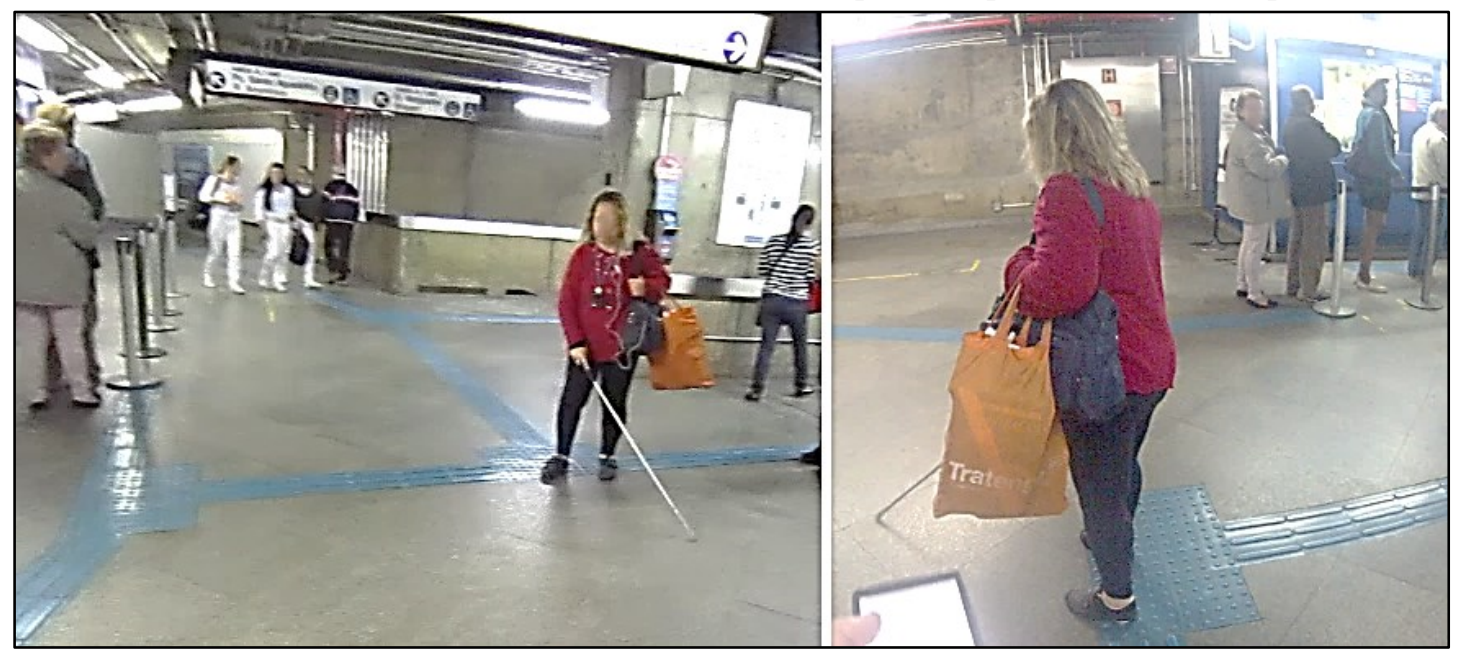

Fonte: do autor (2016) 
Neste ponto do mezanino os voluntários receberam a informação vocal "Esquerda: Centro Cultural. Direita: Colégio Santo Agostinho", precedida da melodia de contraste para o ruído ambiental. No entanto, diferentemente da decisão na plataforma de todos os voluntários em deixar o piso tátil para seguir pelas escadas ao invés do elevador, a sinalização neste ponto não consiste somente de piso tátil direcional. Como o primeiro piso tátil de alerta não possui ligação para a esquerda, a informação auditiva terminou por conflitar com a informação tátil.

O tempo total da audiodescrição neste ponto é de seis segundos, que demanda de iniciar a instrução a quase quatro metros antes do ponto de bifurcação, distância adequada para a velocidade dos voluntários, mas discordante com a sequência e as distâncias sinalizadas pelo piso tátil.

A voluntária "DA" também percebeu a discrepância entre a informação da audionavegação, da presença do piso tátil de alerta e da ausência do piso tátil direcional, e hesitou em continuar, saindo e retornando várias vezes ao piso tátil. Neste caso, sua dúvida despertou a curiosidade de uma transeunte, que, na tentativa de auxiliar a voluntária, direcionou-a incorretamente para o piso tátil que leva ao acesso leste da estação (foto 19).

Foto 19 - Voluntária “DA” na bifurcação dos acessos

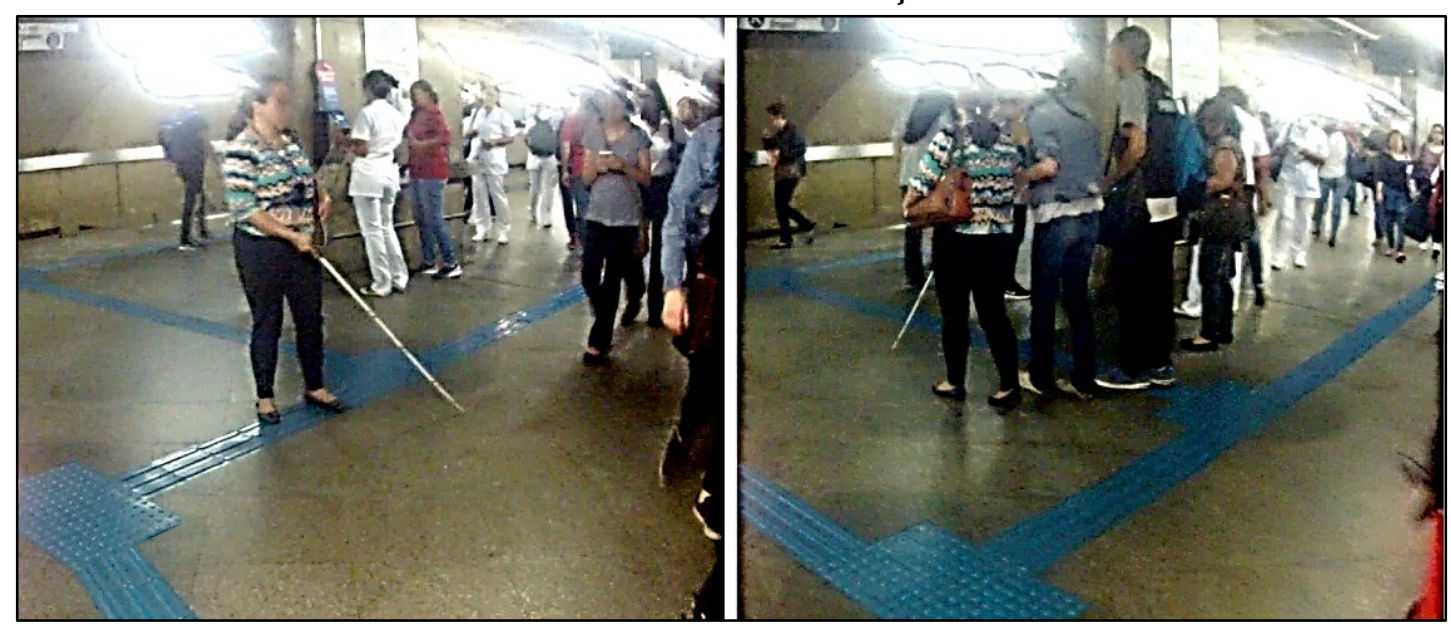

Fonte: do autor (2016)

Alguns segundos depois esta mesma pessoa abordou novamente a voluntária, corrigindo sua direção. 
Os voluntários apresentaram comportamentos diferentes nesta situação. "EB", "IC" e "SE" também saíram antes do final da instrução, mas não hesitaram, seguindo a instrução e chegando ao piso tátil logo à frente. Por outro lado, os voluntários "RB" e "MR" não demonstraram hesitação, mas procuraram o piso tátil direcional antes de seguirem no trajeto. Estas ações dos voluntários são mais bem observadas no quadro 17.

Quadro 17 - Ação dos voluntários para a informação de bifurcação para os acessos

\begin{tabular}{llll}
\hline & & Buscaram o piso tátil & Tempo para seguir \\
\hline & DA & Sim & 81 segundos \\
\cline { 2 - 4 } & EB & Não & Seguiu imediatamente \\
\cline { 2 - 4 } & IC & Não & Seguiu imediatamente \\
\hline & MR & Sim & 6 segundos \\
\cline { 2 - 4 } & RB & Sim & 10 segundos \\
\hline RC & Sim & Não & 30 segundos \\
\hline
\end{tabular}

Fonte: do autor (2016)

Enquanto cumpriam seu trajeto, os voluntários não demonstraram que se distraiam com as situações presentes nos ambientes escolhidos. Enquanto caminhavam pela plataforma, havia ruídos dos trens e trânsito de pessoas, alguns inclusive esbarrando no corpo e na bengala dos voluntários, sem que estas ocorrências causassem dúvidas quanto ao trajeto.

Apesar de o pesquisador ter sugerido aos voluntários a não aceitarem auxílio de pessoas alheias ao estudo, algumas se aproximavam dos voluntários e ofereciam auxílio. Com exceção da ocorrência com a voluntária "DA" na bifurcação que leva aos acessos da estação, todas as ofertas de auxílio foram recusadas pelos voluntários. No entanto, observou-se que ocorreram distrações que provocaram erros no trajeto quando as pessoas interrompiam os voluntários nos momentos que estavam ouvindo instruções da audionavegação.

Foram observados erros provocados por distrações durante o acompanhamento das voluntárias "IC" e "DA". A voluntária "IC" foi distraída logo no início do trajeto, quando ia escolher a escada que a levaria da plataforma ao mezanino. Logo após virar à direita para acessar as escadas, a audionavegação descreveu o posicionamento das escadas ("Escadas à direita. Primeira, rolante. Segunda, fixa"). 
No entanto, no exato momento que estava recebendo esta instrução, uma usuária do Metrô aproximou-se e ofereceu auxílio. Apesar da voluntária "IC" ter recusado o auxílio, sua atenção à audionavegação foi prejudicada, dificultando a localização das escadas. Esta ocorrência pode ser vista na foto 20: à esquerda, a usuária do Metrô (vestindo casaco azul com gola cinza) interrompeu a voluntária "IC" (vestindo jaqueta vermelha). À direita, a voluntária "IC" busca a escada com a bengala, pois a interrupção da usuária do Metrô a impediu de ouvir a instrução sobre a localização das escadas. A própria voluntária encontrou a escada rolante alguns segundos depois.

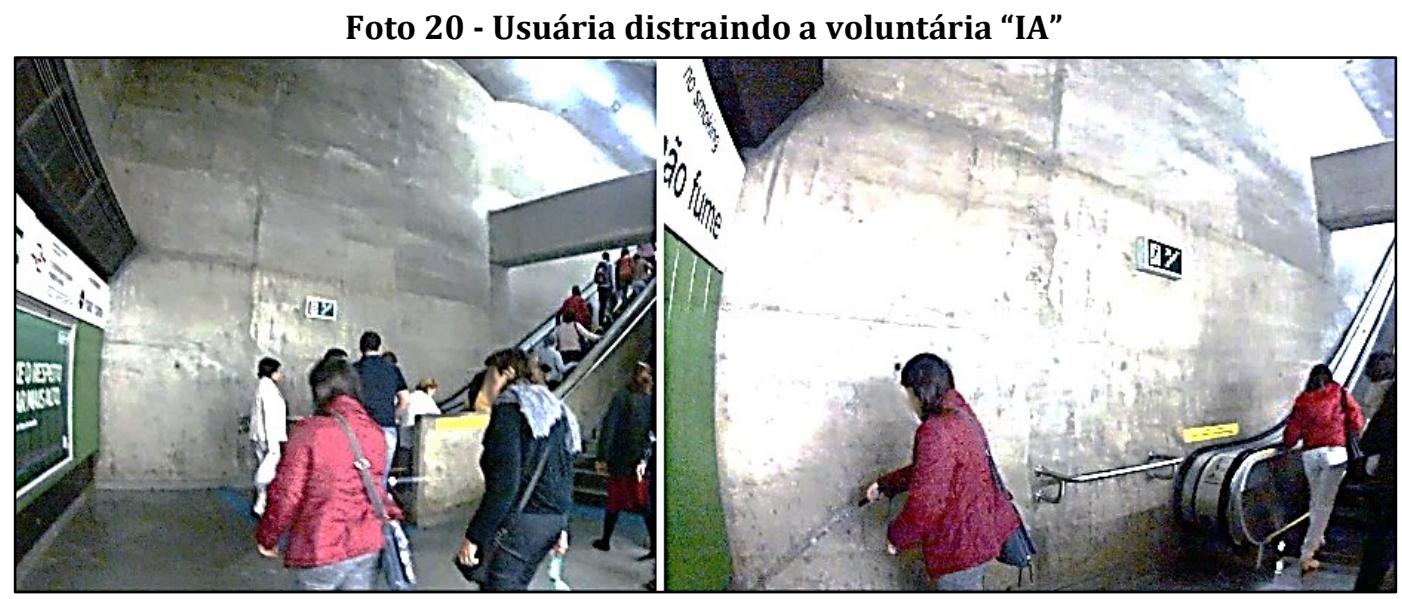

Fonte: do autor (2016)

As situações de distração dos voluntários por outras pessoas não podem ser evitadas. Mas podem existir métodos a serem incorporados à interface de audionavegação que minimizem os erros causados pelas distrações, como por exemplo, disponibilizar para o usuário a opção de repetir as instruções.

O caminho entre a estação Vergueiro e o Centro Cultural consiste em uma calçada em aclive, com cerca de 120 metros de comprimento. É uma área pública delimitada por muretas de $30 \mathrm{~cm}$ de altura em ambos os lados, que não possui piso tátil instalado, e que provém acesso do viaduto Beneficência Portuguesa até os portões do Centro Cultural São Paulo (foto 21, página 164). 
Foto 21 - Rampa de acesso ao Centro Cultural São Paulo

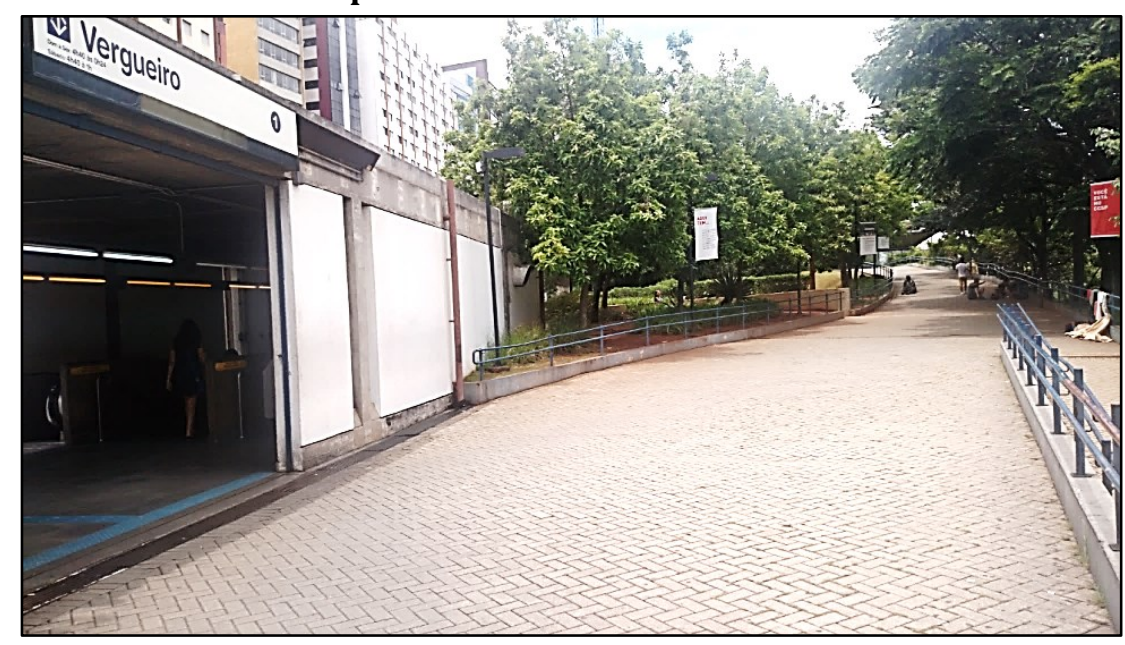

Fonte: do autor (2016)

Os voluntários utilizaram esta calçada como trajeto para chegar ao Centro Cultural, saindo do acesso Oeste da estação Vergueiro, localizada no viaduto Beneficência Portuguesa. É um trecho do trajeto que toma um grande tempo de caminhada. Os voluntários utilizaram tempos diferentes para cumprir este trecho do trajeto, pois, devido à sua distância e à ausência de obstáculos, o tempo utilizado dependeu exclusivamente da velocidade e do tamanho dos passos de cada voluntário.

A rampa de acesso é ao ar livre, arborizado, mas tem proximidade com a Rua Vergueiro e apresenta circulação constante de pessoas. Então os ruídos presentes são característicos, podem existir barulhos de veículos automotores sem que estes estejam de fato no caminho, transmitindo a sensação de estar próximo à rua e aos veículos. Além disso, e o tempo de caminhada é relativamente longo, sem desvios, bifurcações ou riscos ambientais. Do aspecto da audionavegação esta situação pode ser incômoda, pois não existem elementos ambientais que exijam sua audiodescrição, mas o silêncio do equipamento por longos períodos ou distâncias pode confundir ou transmitir a sensação de insegurança às pessoas com deficiência visual.

Seguindo as recomendações obtidas dos convidados na pesquisa piloto da ADEVA, foi inserida na audionavegação a frase "você está seguindo no sentido Centro Cultural São Paulo", que consiste basicamente de uma audiodescrição da direção que o voluntário está seguindo. 0 propósito do uso desta audiodescrição foi transmitir uma informação objetiva sobre a direção que o voluntário estaria 
seguindo, e uma informação de caráter subjetivo, mas também de fundamental importância, que é a confirmação que o equipamento de orientação continua em funcionamento. Esta frase foi dita a cada 50 metros de calçada, sendo transmitida por duas vezes ao longo do acesso ao Centro Cultural.

Não foram utilizadas medidas de distância, como metros ou passos, assim como também não foi utilizada medidas de tempo, seguindo-se as recomendações dos convidados para as entrevistas e da pesquisa prática na ADEVA, mostradas nos resultados dos capítulos 4.1 e 4.2, respectivamente nas páginas 143 e 145 .

As observações no interior do Centro Cultural, desde a entrada até a porta da Biblioteca Louis Braille, é um caminho direto, em nível e sinalizado por piso tátil. Os voluntários não demonstraram dificuldades em seguir este trajeto após a rampa de acesso ao Centro Cultural São Paulo. A foto 22 ilustra esta sequência direta do piso tátil no interior do Centro Cultural São Paulo: à esquerda, a entrada do portão e início do piso tátil do Centro Cultural. Ao centro, a continuidade do piso tátil até a porta de vidro da área coberta. À direita, o piso tátil da área coberta, seguindo diretamente até a porta da Biblioteca Louis Braille. Toda esta sequência tem cerca de 50 metros, o piso tátil ao longo deste trajeto é direto, sem interrupções, o que representa uma facilidade para que os voluntários seguissem de forma rápida e direta.

Foto 22 - Centro Cultural São Paulo - piso tátil do portão até a biblioteca Louis Braille

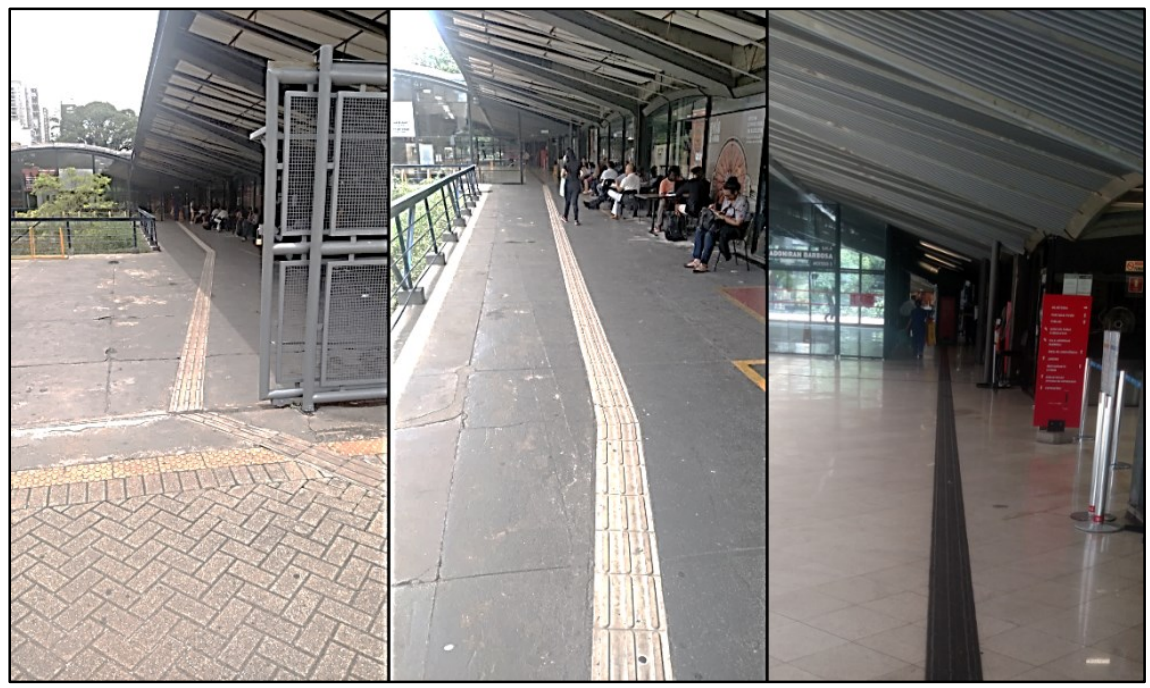

Fonte: do autor (2016) 
Todos os voluntários acessaram a portaria do Centro Cultural São Paulo por este piso tátil ilustrado na foto 22 da página 165. Desta forma, percorreram o trajeto entre o portão do Centro Cultural São Paulo e a entrada da biblioteca Louis Braille em menos de três minutos. As fotos 23, 24 e 25 (páginas 166 e 167) mostram voluntários seguindo por este piso tátil.

Foto 23 - Voluntário "EA" seguindo pelo piso tátil até a porta da biblioteca Louis Braille

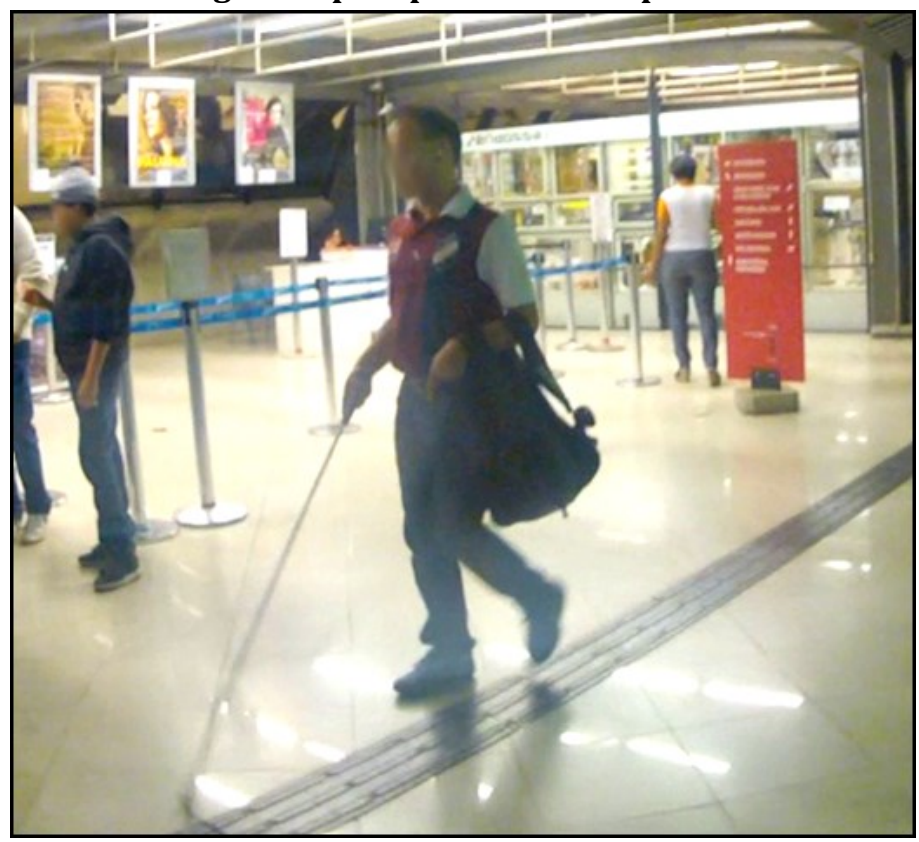

Fonte: do autor (2016)

Foto 24 - Voluntário “RB” seguindo pelo piso tátil até a porta da biblioteca Louis Braille

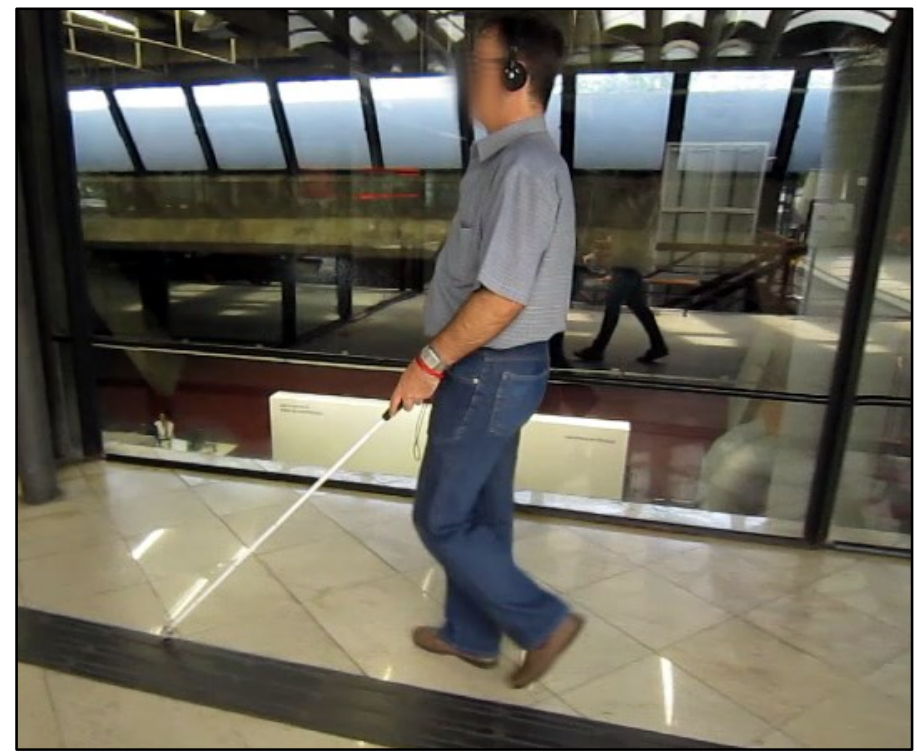

Fonte: do autor (2016) 
Foto 25 - Voluntário “SE” seguindo pelo piso tátil até a porta da biblioteca Louis Braille

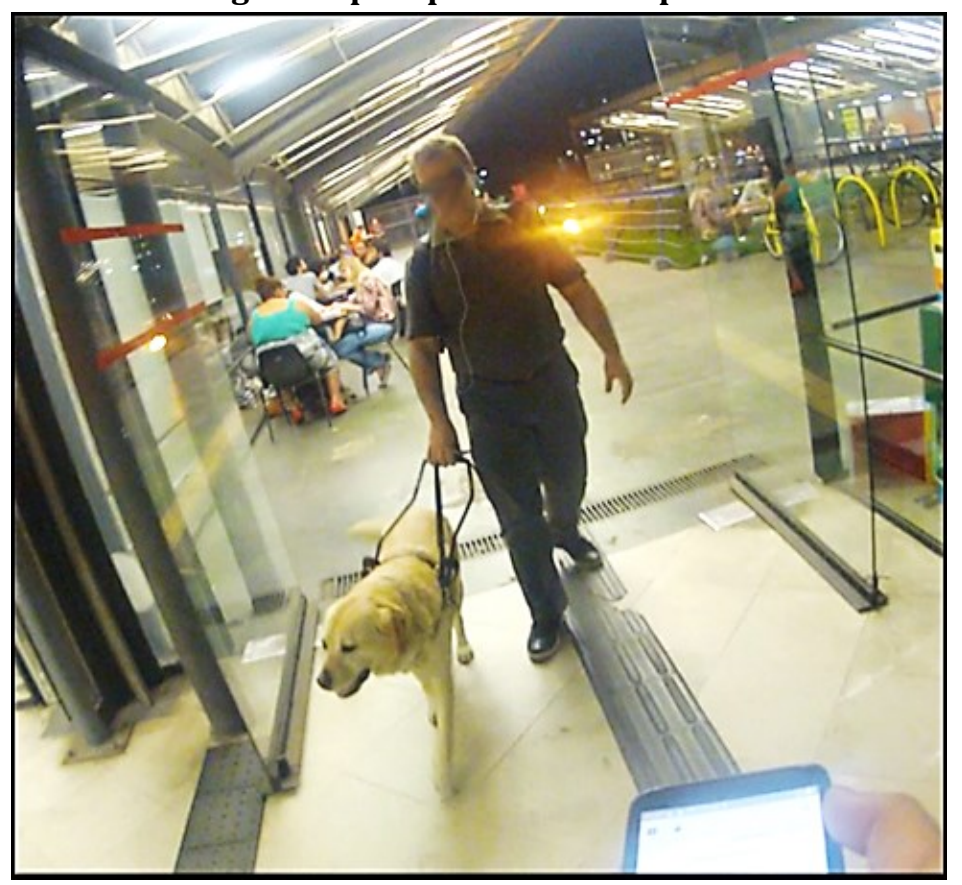

Fonte: do autor (2016)

As fotos 26, 27, 28 e 29 (páginas 167 a 169) mostram voluntários chegando à porta da biblioteca Louis Braille:

Foto 26 - Voluntária “IC" chegando à porta de entrada da biblioteca Louis Braille

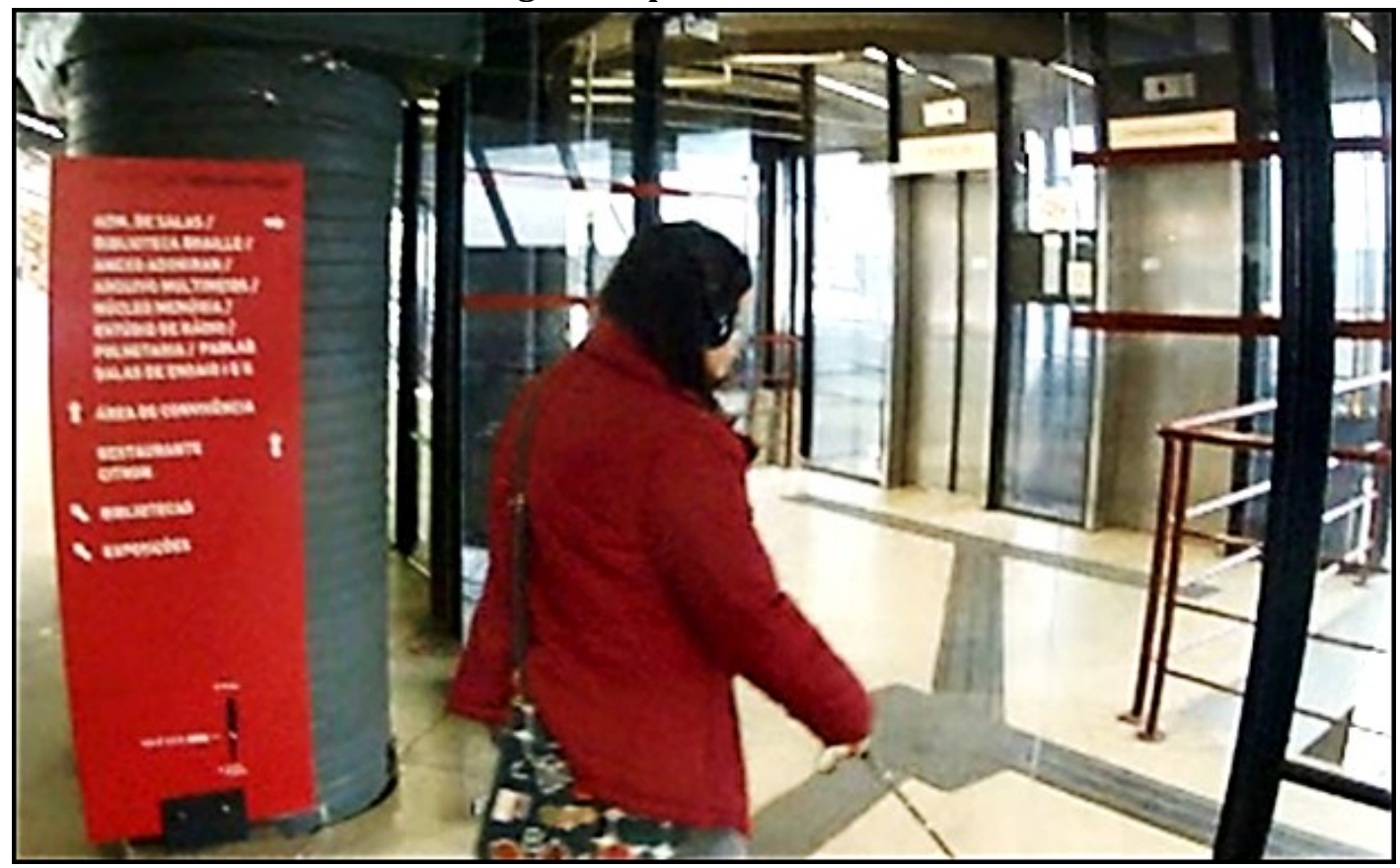

Fonte: do autor (2016) 
Foto 27 - Voluntário “MR”, porta de entrada da biblioteca Louis Braille

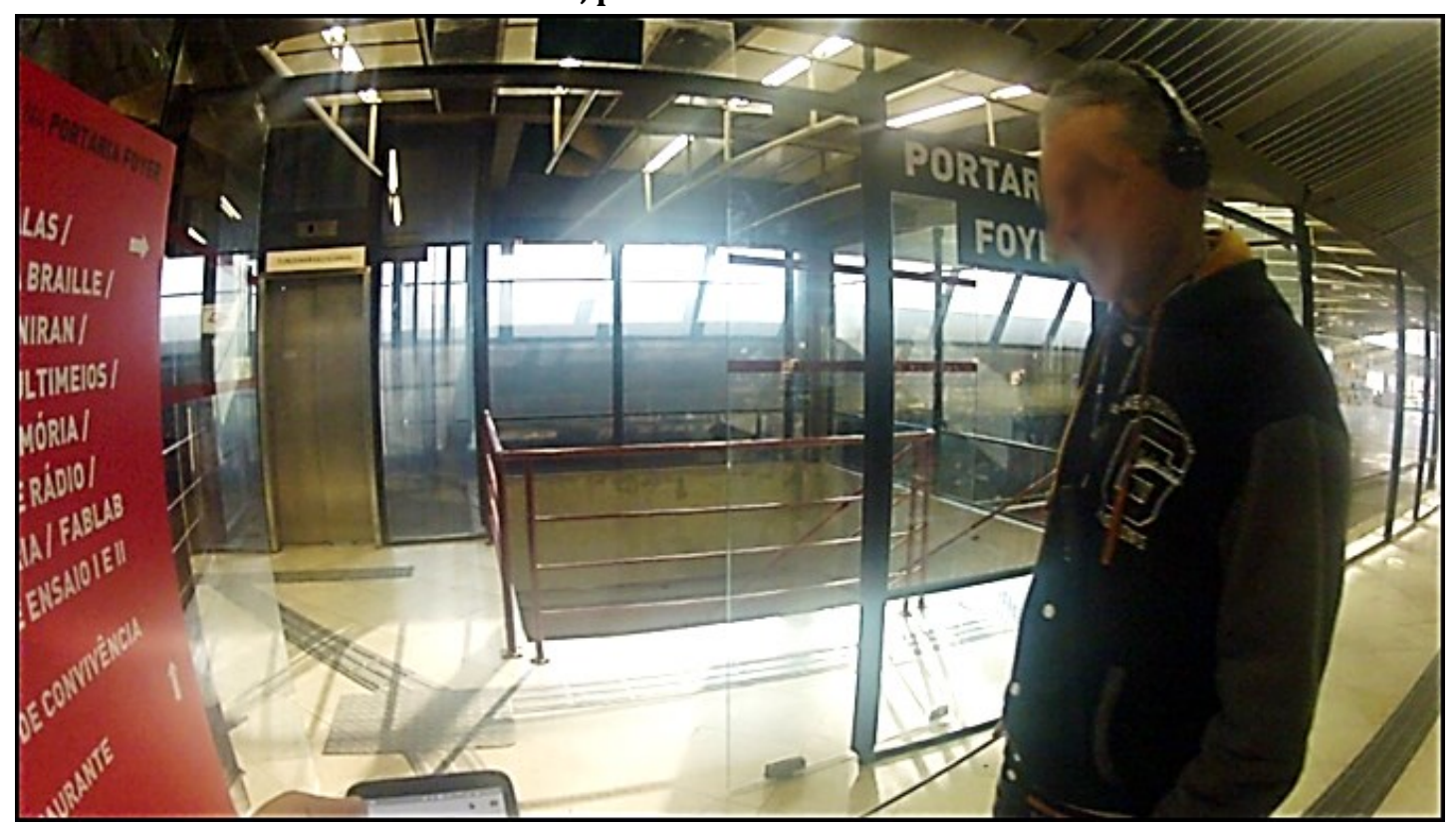

Fonte: do autor (2016)

Foto 28 - Voluntária “DA” chegando à porta da biblioteca Louis Braille

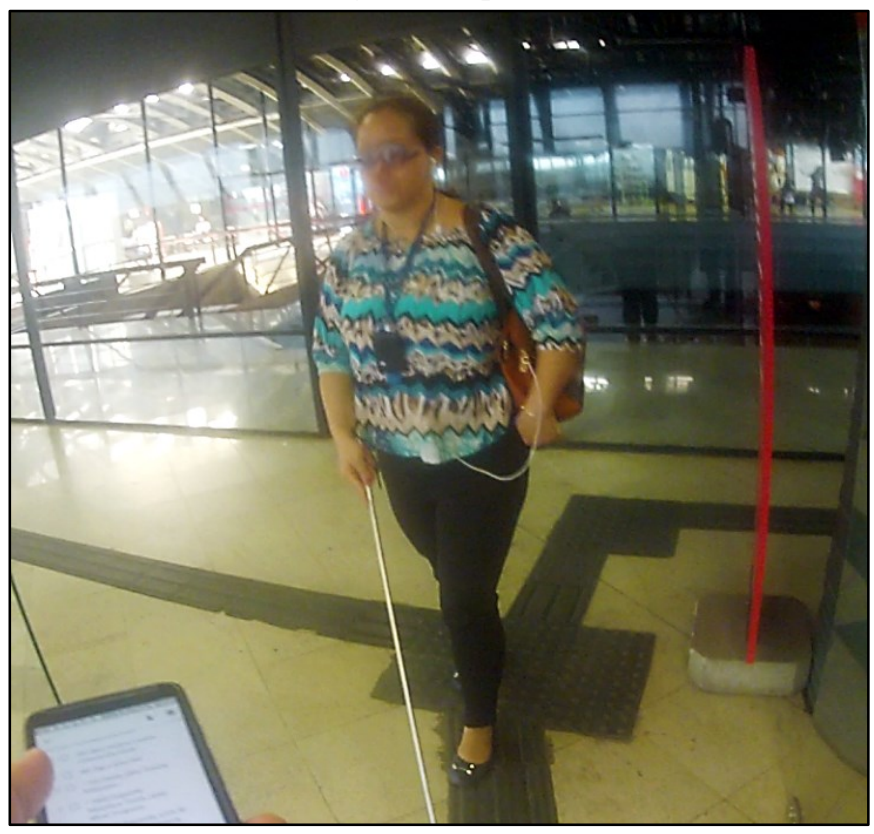

Fonte: do autor (2016) 


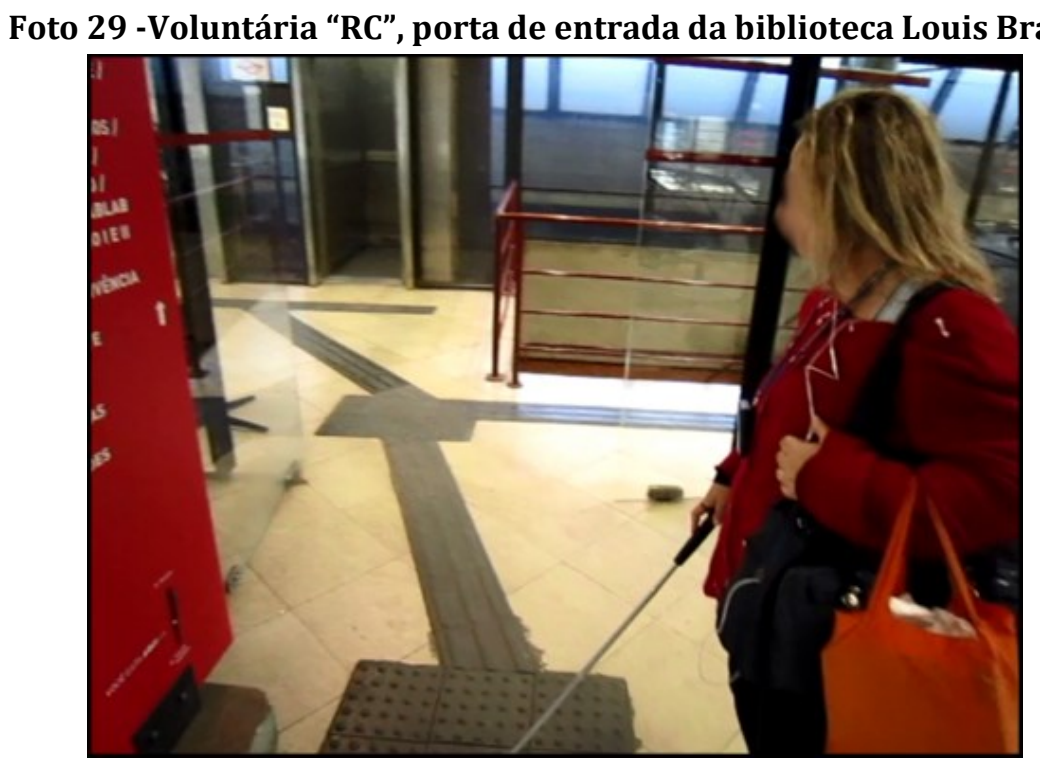

Fonte: do autor (2016)

A biblioteca Louis Braille encontra-se no subsolo do Centro Cultural São Paulo. Todos os voluntários voltaram-se à porta de vidro de acesso à biblioteca no momento em que ouviram a instrução "Direita: biblioteca. Frente: lanchonete" provinda da audiodescrição. Ao entrarem pela porta de acesso, receberam a instrução final "Bem-vindo à Biblioteca Louis Braille. Um atendente irá acompanhá-lo", posto que o atendimento da biblioteca às pessoas com deficiência visual inicia-se logo na entrada, onde há um recepcionista. Esta frase final encerrou as observações práticas. 



\section{CONSIDERAÇÕES FINAIS}

Este trabalho iniciou-se com a proposição que a filosofia do design universal pode ser utilizada na elaboração de princípios para o design de audionavegação em ambientes públicos para pessoas com deficiência visual, por meio da readequação da tecnologia da audiodescrição em um formato apropriado para ser utilizado enquanto os usuários seguem trajetos em ambientes públicos e transportes de massa.

Como preceitos teóricos, foram reunidas informações relevantes que possibilitaram a preparação e o levantamento de dados por meio de entrevistas e observações práticas. Os tópicos da bibliografia envolveram informações sobre os potenciais usuários deste tipo de tecnologia, por meio do levantamento bibliográfico sobre peculiaridades inerentes às pessoas com deficiência visual, abrangendo as características físicas e sociais da deficiência visual, sobre sua capacidade de orientação e mobilidade em espaços públicos e as principais ferramentas existentes para possibilitar a acessibilidade no wayfinding.

Os tópicos que relacionaram os processos cognitivos das pessoas foram levantados bibliografias para o design que possam ser aplicados em interfaces para pessoas com deficiência visual, conduzindo até a necessidade do levantamento de dados bibliográficos que possibilitem a correlação entre o design de sinalização visual e dos sons, conjecturando-se relações de algumas das leis da Gestalt para formas de correspondência entre a imagem e o som.

Os preceitos das correspondências entre as leis da Gestalt e os sons direcionaram o levantamento bibliográfico de ajudas eletrônicas para orientação por voz a pessoas com deficiência visual. Nesta parte dos preceitos teóricos foram investigados os atuais recursos de informação para pessoas com deficiência visual, como a tecnologia da audiodescrição e seus preceitos, os aplicativos de GPS e as atuais interfaces portáteis de smartphones.

Os preceitos teóricos possibilitaram o planejamento, a execução e o tratamento dos dados das pesquisas práticas. 
A bibliografia sobre a audiodescrição demonstrou que esta tecnologia teve como origem a necessidade de criar uma representação vocal de imagens, no objetivo de disponibilizar um modo para que as pessoas com deficiência visual possam participar mais ativamente da sociedade, por meio do acesso ao trabalho, à cultura e ao lazer. A audiodescrição concebe uma ponte entre a imagem de filmes, peças teatrais, pinturas, esculturas e outros elementos visuais por meio de sua descrição. Primitivamente disponibilizada em tempo real, com pessoas realizando a descrição das imagens de programas de TV por meio de voz, as interfaces de audiodescrição constituíram-se primeiramente de equipamentos eletrônicos automatizados com vozes humanas gravadas, e após a popularização dos computadores, evoluíram para aparelhos eletrônicos com vozes digitais, sintéticas.

No entanto, a audiodescrição foi criada para relatar o conteúdo de imagens, seu método não prevê a descrição de trajetos. Para que os conceitos de audiodescrição possam beneficiar também a orientação e a mobilidade, faz-se necessário portar o conceito para um modelo de interface que tenha por princípio conduzir pessoas com deficiência visual, fomentando sua autonomia ao disponibilizar uma ferramenta de audionavegação para que possam seguir percursos em espaços públicos com segurança.

A inexistência de bases teóricas e práticas para o design de audionavegação tornou necessário o levantamento de conceitos que possibilitem a elaboração de métodos para a elaboração de construções verbais, mesmo que de forma primitiva, a serem inseriras em um sistema básico que forneça audionavegação para que voluntários com deficiência visual pudessem usar durante ciclos de experimentos práticos. Optou-se por perguntar diretamente aos usuários com deficiência visual, por meio de entrevistas semiestruturadas de caráter qualitativo. Estas entrevistas foram concretizadas com o auxílio da Associação de Deficientes Visuais e Amigos (ADEVA), na cidade de São Paulo. A associação fez o convite a seus membros e forneceu o local para as entrevistas.

Dentre os convidados pela ADEVA para as entrevistas sobre construções verbais, foram selecionados os que possuem autonomia em orientação e mobilidade, no objetivo de colher informações de pessoas com deficiência visual que possuem 
experiência em locomoverem-se por locais públicos e transportes de massa, buscando-se desta forma um conhecimento pertinente sobre direcionamento que torne familiar a audiodescrição ambiental para pessoas com deficiência visual.

As entrevistas foram registradas por meio de gravação de áudio e anotações em papel. Os registros foram catalogados posteriormente, no objetivo de se buscar padrões de respostas para cada série de construções verbais. As análises de cada série de respostas foram efetuadas logo após a entrevista de cada convidado, por meio da comparação com as respostas fornecidas pelos entrevistados anteriores. A análise do segundo convidado demonstrou que os conteúdos eram essencialmente idênticos, análise esta que se repetiu nas entrevistas seguintes. Por este motivo as entrevistas cessaram após o sexto convidado, pois já estavam resultando em dados saturados.

Os dados obtidos com a análise das entrevistas possibilitaram a formulação de construções verbais para a incorporação em um sistema eletrônico de voz sintetizada, tornando possível a execução de um estudo preliminar de audionavegação. Este estudo prático preliminar foi executado no interior da ADEVA, que forneceu uma área isolada, com ausência de circulação de pessoas, tornando possível a observação dos voluntários sem que houvesse interferências. O objetivo deste estudo preliminar foi avaliar as construções verbais obtidas por meio das entrevistas, possibilitando sua adequação com peculiaridades referentes à disponibilização das verbalizações por meio de aparelhos eletrônicos com voz sintetizada, relacionando estas peculiaridades com as capacidades cognitivas dos voluntários que utilizaram o sistema.

Para as observações deste estudo preliminar, a ADEVA convidou quatro de seus associados, que possuem deficiência visual. As experiências práticas foram executadas por meio de quatro percursos distintos, realizadas em três dias. Os convidados da ADEVA foram selecionados quanto ao seu grau de deficiência visual, seja cegueira ou baixa visão, e quanto às suas experiências no uso de aparelhos eletrônicos com voz sintetizada, no objetivo de associar particularidades de seus conhecimentos às observações coletadas durante o uso da audionavegação. 
A ADEVA reuniu quatro voluntários para as observações preliminares, assim como forneceu uma especialista em orientação e mobilidade para comentar as peculiaridades observadas nas ações dos voluntários durante o uso da audionavegação. As experiências práticas no ambiente da ADEVA tornaram possível a obtenção de informações importantes sobre construções verbais para a audiodescrição de distâncias, incluindo-se a necessidade de comunicar que o equipamento está funcionando em situações as quais não existem informações por longos períodos de tempo, assim como levantar informações sobre preferências do usuário acerca de indicações sobre a existência de linhas-guia diferentes do piso tátil. Também despertou a necessidade de se realizar um estudo dos ambientes públicos quanto aos níveis de ruído de áudio, que, juntamente da necessidade de se manter uma das mãos do usuário livre de acordo com as técnicas de orientação e mobilidade, evidenciou a necessidade do uso de fones de ouvido.

As observações e depoimentos dos convidados da ADEVA demonstraram a importância em se estudar as frases a serem transmitidas, no objetivo de informar corretamente sobre o ambiente e o trajeto. Por utilizarem o som como principal fonte de informação sobre o ambiente, frases muito extensas podem influenciar na forma de caminhar de pessoas com deficiência visual, obrigando-os a parar por certo tempo para ouvir a informação correta, ação indesejável em um ambiente repleto de pessoas caminhando. Pelo mesmo motivo, informações discordantes podem confundir ao invés de ajudar. No entanto, se a audiodescrição para navegação for muito curta, a informação presente pode ser insuficiente, também levando à confusão. Assim, para a audionavegação, faz-se necessário um cuidado apurado quanto às frases ditas pela audiodescrição, buscando a melhor integração com os ambientes, e considerando sempre os elementos culturais, experiências prévias dos usuários, facilitando os processos cognitivos.

Os experimentos na ADEVA forneceram conhecimentos que possibilitaram o refinamento dos conteúdos verbais a serem embutidos na audionavegação, possibilitando a preparação e a execução dos experimentos em ambientes públicos. 
Para os experimentos práticos de audionavegação em ambientes públicos, buscouse selecionar locais públicos de uso frequente por pessoas com deficiência visual. Optou-se pelo conjunto de ambientes públicos formado pela Estação Vergueiro do Metrô de São Paulo, pelo calçamento que segue do acesso oeste da estação até os portões do Centro Cultural São Paulo e pelo interior do Centro Cultural São Paulo, até a porta da biblioteca acessível Louis Braille. Pelas características do conjunto de ambientes públicos escolhido, foi possível observar situações relacionadas ao percurso por estação de transporte público, por uma calçada relativamente longa e pelo interior de um estabelecimento cultural, três ambientes diferentes que possibilitaram a observação de situações diferentes durante a audionavegação.

Os voluntários para os experimentos práticos em espaços públicos foram disponibilizados pelo Metrô de São Paulo, por meio de contatos com seus usuários com deficiência visual. Após o primeiro voluntário, os demais foram chamados sob demanda, ao longo da pesquisa, após o levantamento e a categorização dos dados obtidos durante as observações do voluntário anterior, buscando-se padrões de aspecto qualitativo acerca do comportamento dos voluntários e de peculiaridades sobre os trajetos que pudessem indicar a saturação de dados por repetição. Os voluntários escolhidos são representantes de diferentes graus de deficiência visual e de experiência com orientação e mobilidade.

Diferentemente do ambiente controlado disponível na ADEVA, os ambientes públicos apresentaram ruídos sonoros que podiam dificultar a audição das vozes provindas da audionavegação. Por este motivo, antes do início do percurso de cada voluntário, foram disponibilizados fones de ouvido de três tipos diferentes para a redução do ruído, possibilitando a audição da audionavegação, mas a opção de usar o viva-voz do smartphone foi mantida, caso os voluntários desejassem. Quatro dos voluntários preferiram usar fones de ouvido do tipo earphones, de uso particular de cada um deles, enquanto três voluntários preferiram usar os headphones cedidos para a pesquisa.

Os trajetos foram realizados a partir da porta de saída do trem, na plataforma oeste da Estação Vergueiro e finalizando na porta de acesso à biblioteca Louis Braille, no interior do Centro Cultural São Paulo, onde a observação era encerrada. 
Todos os voluntários atingiram o destino, na porta da biblioteca Louis Braille. No entanto, houveram situações notáveis a serem catalogadas, como interrupções do trajeto por pessoas que ofereciam auxílio aos voluntários e discrepâncias de informação da audionavegação com outras percepções dos voluntários acerca dos ambientes.

Os experimentos práticos em locais públicos possibilitaram a compreensão que a informação por audionavegação é semelhante à informação visual acerca dos ambientes. No entanto, observaram-se diferenças perceptuais dos voluntários relacionada à sequência com que estes elementos são percebidos, que podem assemelhar-se aos conceitos da Gestalt, mas na esfera da percepção auditiva, pois as capacidades cognitivas da visão tenderam a se repetir também na percepção auditiva, com peculiaridades inerentes às duas diferentes formas de perceber o mundo. Um exemplo se mostrou na utilização dos fones para reduzir o volume do ruído ambiente, que causa o predomínio da informação da audionavegação sobre o fundo ruidoso. 0 mesmo princípio foi observado quando da interrupção gerada por pessoas oferecendo auxílio aos voluntários, causando o predomínio da interrupção sobre a informação da audionavegação, indicando que a informação provinda da voz humana ganha destaque em relação à informação atemporal dada pelo aparelho com voz sintetizada, pois as duas informações instrucionais fornecidas por agentes distintos ao mesmo tempo não permitiram o discernimento das instruções da audionavegação por parte do usuário.

Ao observar-se o comportamento dos voluntários caminhando pela calçada de acesso, entre a Estação Vergueiro e o Centro Cultural São Paulo, a existência da frase de confirmação demonstrou-se muito eficiente. Em todas as observações os voluntários aumentaram levemente sua velocidade ao ouvirem a confirmação que estavam seguindo no sentido esperado e que o equipamento continuava em funcionamento.

Durante o experimento no interior da Estação Vergueiro observou-se que alguns voluntários saíam do trajeto esperado um pouco antes do tempo, levando-os a encontrar paredes antes dos acessos desejados. Semelhantemente, alguns voluntários demonstraram alguma dúvida quanto à informação sobre o acesso que 
precisariam seguir, no mezanino da Estação Vergueiro, antes da curva que levaria ao acesso oeste. A dúvida ocorreu devido à densidade de informações necessárias para descrever aquele local por áudio, alongando o tempo da sequência de audio, indicando que as pessoas tendem a seguir partes das instruções na medida em que as vão recebendo, ao invés de ouvirem a instrução completa antes de agirem.

A singularidade desta situação demonstra a necessidade de estudar formas precisas de audiodescrição para a audionavegação em locais com grande densidade de informações importantes. A simples reprodução de sinalizações visuais pode não ser suficiente na sinalização vocal, e o designer precisa desenvolver um modelo de informação que transcreva o ambiente sem sobrecarregar a memória do usuário. Os preceitos teóricos demonstraram, pelo estudo dos processos cognitivos, do wayfinding e das sinalizações visuais, que a informação visual possibilita a captura da imagem dos elementos do ambiente como um todo, restando aos processamentos cognitivos do indivíduo gerar a sequência de seu interesse. Em contrapartida, a observação dos experimentos práticos possibilitou a compreensão que a audionavegação, por constituir-se de informações por meio de linguagens sonoras verbais, já fornece a sequência dos elementos do ambiente por meio da audiodescrição, restando ao processamento cognitivo dos indivíduos somente a seleção da informação que é de seu interesse, seleção esta que ocorre no momento em que a audiodescrição descreve o elemento ambiental de interesse para indivíduo.

Observou-se que a memória é o processo cognitivo mais exigido em interfaces de audiodescrição, principalmente se for utilizada para audionavegação. 0 fato de a pessoa estar deslocando-se, ocupando o processo da atenção, faz com que sua memória de curto prazo esteja ocupada com as tarefas de reconhecer os elementos do ambiente. Por este motivo, a sequência de apresentação dos elementos é um dos focos do designer de audionavegação, que deve elaborar cuidadosamente a sequência a ser inserida na audionavegação por meio do estudo dos elementos ambientais a serem informados, do conteúdo desta informação, do tamanho de cada informação da sequência, do momento que a informação se iniciará e do momento que o indivíduo a compreenderá, observando-se, ainda, se cada elemento da informação não será conflitante ou não dependerá de outras informações, tanto 
no ambiente quanto nas própria audionavegação, principalmente as informações que ainda não foram disponibilizadas para o usuário.

Independentemente de quais conteúdos verbais sejam necessários para guiar pessoas com deficiência visual pelas diversas situações existentes nos ambientes públicos, constatou-se a necessidade de seguir uma estratégia específica de design para a audionavegação, por meio de uma sequência lógica e encadeada para cada condição ambiental a ser descrita. Como sugestão para pesquisas futuras, o autor propõe pesquisas com as premissas citadas abaixo, obtidas por meio dos experimentos deste estudo.

As verbalizações não podem conflitar com nenhum dos recursos preexistentes acerca das orientações que elas indicam. Desta forma, deve-se realizar um levantamento das características de direções possíveis, de conteúdos de placas de sinalização visual, das indicações existentes nos pisos táteis, de pontos de referência, de pontos de bifurcação e de possíveis interferências de objetos e obstáculos. De posse desses dados, deve-se criar as verbalizações para cada um dos cenários possíveis.

Após a elaboração das verbalizações, calcula-se o tempo que a voz digital consumirá para transmiti-la ao usuário. Conhecidos os tempos de cada verbalização, deve-se adotar uma sequência lógica para sua apresentação, que deve considerar uma hierarquia de apresentação que considere a direção que o usuário está seguindo, a sequência cronológica de cada informação, a sequência adotada por outros recursos de acessibilidade como o piso tátil e a prioridade de importância de cada mensagem.

Formulada esta sequência, deve-se usar os tempos de verbalização de cada informação, relacionando-os à velocidade média do passo das pessoas com deficiência visual, posicionando o início de cada uma de forma à pessoa compreender seu conteúdo no momento e local exato de decidir se deve mudar de direção. 
Independentemente de quais conteúdos verbais sejam necessários para guiar pessoas com deficiência visual pelas diversas situações existentes nos ambientes públicos, constatou-se a necessidade de seguir uma estratégia específica de design para a audionavegação, por meio de uma sequência lógica e encadeada para cada condição ambiental a ser descrita.

Considerando que as verbalizações não podem conflitar com nenhum dos recursos preexistentes acerca das orientações que elas indicam, a sequência de desenvolvimento deve ser iniciada com o levantamento das características de direções possíveis, de conteúdos de placas de sinalização visual e de pontos de referência, além das indicações existentes nos pisos táteis, de pontos de bifurcação e de possíveis interferências de objetos e obstáculos. De posse desses dados, devem-se criar verbalizações para cada um dos cenários e direções possíveis, obtendo-se conteúdos sintéticos, porém completos, que reflitam as informações obtidas, disponíveis por meio da análise dos pontos de referência, das direções e de sinalizações visuais preexistentes.

Após a elaboração das construções verbais, deve-se calcular o tempo que a voz digital consumirá para transmiti-la ao usuário. Conhecidos os tempos de cada verbalização, deve-se adotar uma sequência lógica de apresentação, concebendo uma hierarquia que considere a direção que o usuário está seguindo, a sequência cronológica de cada informação, a sequência adotada por outros recursos de acessibilidade como o piso tátil e a prioridade de importância de cada mensagem.

Formulada esta sequência, devem-se usar os tempos de verbalização de cada informação, relacionando-os à velocidade média do passo das pessoas com deficiência visual, posicionando o início de cada parte da informação verbal de forma à pessoa compreender seu conteúdo no momento e local exato de decidir se deve mudar de direção, independentemente se outras partes da informação verbal seguirão informando outras situações sobre o local. 



\section{REFERÊNCIAS}

ABNT. NBR 9050:2015 - Acessibilidade a edificações, mobiliário, espaços e equipamentos urbanos. ABNT - Associação Brasileira de Normas Técnicas. Rio de Janeiro, p. 148. 2015. (978-85-070-5706-2).

ABNT. NBR 16537:2016 - Acessibilidade - Sinalização tátil no piso - Diretrizes para elaboração de projetos e instalação. Associação Brasileira de Normas Técnicas ABNT. Rio de Janeiro, p. 44. 2016. (978-85-070-6306-3).

ALVAREZ, V. H.; ALVAREZ, G. A. M. Sistema internacional de unidades (SI). Jornal Informações Agronômicas, Peachtree Corners, dez 2008. 19-22. ISSN 2311-5904.

AMARANTE, P. D. D. C.; LIMA, R. Nada sobre nós sem nós: relatório final - oficina nacional de indicação de políticas públicas culturais para inclusão de pessoas com deficiência. Rio de Janeiro: Secretaria da Identidade e da Diversidade Cultural. Ministério da Cultura, 2009. 125 p.

APELT, R.; CRAWFORD, J.; HOGAN, D. Wayfinding design guidelines. 1a․ ed. Brisbane: Cooperative Research Centre for Construction Innovation, 2007. ISBN 97809-804-2629-8.

ARAÚJO, C. D. D.; CÂNDIDO, D. R. C.; LEITE, M. F. Espaços públicos de lazer: um olhar sobre a acessibilidade para portadores de necessidades especiais. LICERERevista do Programa de Pós-graduação Interdisciplinar em Estudos, Belo Horizonte, 12, n. 4, dez. 2009. ISSN 1981-3171.

ARTHUR, P.; PASSINI, R. Wayfinding: people, signs, and architecture. 1‥ ed. New York: Mcgraw-Hill, 1992. 238 p. ISBN 978-00-755-1016-1.

BAKER, R. R. Human navigation and the sixth sense. 1st. ed. New York: Simon \& Schuster, 1982. 138 p. ISBN 978-06-714-4390-0.

BARANAUSKAS, M. C. C.; HORNUNG, H. H.; MARTINS, M. C. Design socialmente responsável: desafios de interface de usuário no contexto brasileiro. Belém: Seminário Integrado de Software e Hardware. 2008. p. 91-105.

BARBOSA, M. B. P. Wayfinding na jornada da pessoa com deficiência visual no sistema metroferroviário. 2015. 549 p. Tese (Doutorado em Arquitetura e Urbanismo). Faculdade de Arquitetura e Urbanismo - FAU. Universidade de São Paulo - USP. São Paulo. 2015.

BARDIN, L. Análise de conteúdo. 70. ed. Lisboa: Persona, 1979. ISBN 978-97-2441154-5.

BAUMANN, S. Introduction to wayfinding and signage design. DesignWorkplan, Amstelveen, 2010.

BAXTER, M. R. Projeto de produto: guia prático para o design de novos produtos. Tradução de Itiro Iida. 3ạ. ed. São Paulo: Blücher, 2011. ISBN 978-85-212-0614-9. 
BEVILACQUA, T. S. 0 conceito de interface no contexto do design. Anais do $3^{\mathbf{o}}$ Congresso Internacional de design da informação, Curitiba, 8 Outubro 2007. 935-940. ISSN 978-85-212-0824-2.

BONSIEPE, G. Del objeto a la interfase: mutaciones del diseño. Buenos Aires: Infinito, 1999. ISBN 98-796-3706-2.

BONSIEPE, G.; DUTRA, C. Design: do material ao digital. São Paulo: Blücher, 1997. ISBN 978-85-212-0871-6.

BRAGA, A. S. Design de interface: as origens do design e sua influência na produção da hipermídia. 2004. 135 p. Dissertação (Mestrado em Comunicação e Semiótica). Pontífica Universidade Católica de São Paulo. São Paulo. 2004.

BRASIL. Lei no 10.098 - Estabelece normas gerais e critérios básicos para a promoção da acessibilidade das pessoas portadoras de deficiência ou com mobilidade reduzida, e dá outras providências. República Federativa do Brasil. Brasília. 19. dez. 2000.

BRASIL. Decreto no 5.296 - Estabelece normas gerais e critérios básicos para a promoção da acessibilidade. República Federativa do Brasil. Brasília. 2 dez. 2004.

BRASIL. Lei no 11.126 de 27 de Junho de 2005 - Dispõe sobre o direito do portador de deficiência visual de ingressar e permanecer em ambientes de uso coletivo acompanhado de cão-guia. República Federativa do Brasil. Brasília. 2005.

BRASIL. Tecnologia Assistiva. Comitê de Ajudas Téncicas. Subsecretaria Nacional de Promoção dos Direitos da Pessoa com Deficiência. Brasília, p. 138. 2009.

BRASIL. Convenção sobre direitos das pessoas com deficiência. $4^{\mathrm{a}}$. ed. Brasília: Secretaria Nacional de Promoção dos Direitos da Pessoa com Deficiência, 2012. ISBN 978-85-608-7718-8.

BRASIL. Resolução 510 - Dispõe sobre as normas aplicáveis a pesquisas em Ciências Humanas e Sociais. Conselho Nacional de Saúde. Ministério da Saúde. Brasília. 2016.

BRITO, J. D. Sistemática para avaliação de conformidade: uma proposta para uso de cão-guia. 2009. 85 p. Dissertação (Mestrado em Sistemas de Gestão). Universidade Federal Fluminense. Centro Tecnológico. Niterói. 2009.

BRITO, L. F. D. S.; STRAUSS, E.; MELLO, F. L. Uso de reconhecimento automático de voz em português do Brasil na geração de closed caption. Anais do Congresso da Sociedade Brasileira de Engenharia de Televisão, Rio de Janeiro, 6, n. 6, 2012. ISSN 1981-4984.

$\mathrm{BROCH}, \mathrm{J}$. C. 0 conceito de affordance como estratégia generativa no design de produtos orientado para a versatilidade. 2010. 99 f. Dissertação (Mestrado em Design e Tecnologia). Faculdade de Design. Universidade Federal do Rio Grande do Sul. Porto Alegre. 2010. 
BRUMER, A.; PAVEI, K.; MOCELIN, D. G. Saindo da "escuridão": perspectivas da inclusão social, econômica, cultural e política dos portadores de deficiência visual em Porto Alegre. Sociologias, Porto Alegre, 6, n. 11, jan. / jun. 2004. 300 - 327. ISSN 1517-4522.

BUEnO, M. A cor e a visão humana. Revista Dental Press, Maringá, 2010. 36-41. ISSN 1980-5500.

CARLIN, F.; ELY, V. H. M. B. A acessibilidade espacial como um dos condicionantes ao conforto de usuários em shopping centers - um estudo de caso. Encontro Latino Americano de Conforto no Ambiente Construído, Maceió, 5-7 out. 2005. 306-315. ISSN 2175-6333.

CARVALHO, J. O. F. Referenciais para projetistas e usuários de interfaces de computadores destinadas aos deficientes visuais. 1994. 162 p. Dissertação (Mestrado em Engenharia Elétrica). Faculdade de engenharia. Universidade Estadual de Campinas. Campinas. 1994.

CARVALHO, J. O. F.; ARANHA, M. C. L. F. M. ProAces/DV - Projeto de acessibilidade aos alunos deficientes visuais da PUC-Campinas - Aspectos tecnológicos. Anais do XVIII Congresso Nacional da Sociedade Brasileira de Computação, Belo Horizonte, 1998. 557-567.

CASALS, B. C. Movilidad con perro-guía: bastón y guía vidente como elementos complemnetarios de familiarización con nuevos entornos. Integracion Revista Sobre Cegueira y Deficiencia Visual, Barcelona, n. 52, dic. 2007. 33 - 37. ISSN 18873383.

CERQUEIRA, J. B. Bengala branca - símbolo de independência das pessoas cegas. Bengala legal, 24 out. 2011.

CIPRO NETO, P.; INFANTE, U. Gramática da língua portuguesa. São Paulo: Editora Scipione, 1998. ISBN 978-85-262-7076-3.

CRESWELL, J. W. Investigação qualitativa e projeto de pesquisa - escolhendo entre cinco abordagens. Tradução de Sandra Mallmann Rosa. 3ㄹ. ed. Porto Alegre: Penso, 2014. ISBN 978-85-658-4888-6.

DANTAS, D. Design orientado para o futuro, centrado no indivíduo e na análise de tendências. 350 p. Tese (Doutorado em Arquitetura e Urbanismo). Faculdade de Arquitetura e Urbanismo - FAU. Universidade de São Paulo - USP. São Paulo, p. 350. 2005.

DANTAS, F. Teoria e leitura da música para as filarmônicas. Salvador: Selo Editorial da Casa das Filarmônicas, 2003. ISBN 85-980-2101-06.

DAVID, J. D. S.; ANTUNES, X. M.; GURGEL, V. T. Cidade acessível: igualdade de direitos e particularidades da pessoa com deficiência visual. Mnemosine, Rio de Janeiro, 5, n. 1, 2009. 80-94. ISSN 1809-8894. 
DECASTRO, E. M.; PAULA, A. I. D.; TAVARES, C. P. Orientação espacial em adultos com deficiência visual: efeitos de um treinamento de navegação. Psicologia: Reflexão e Crítica, 17, n. 2, 2004. 199-210. ISSN 0102-7972.

DISCHINGER, M. Designing for all senses: accessible spaces for visually impaired citizens. 2000. 270 p. Thesis (Doctor of Philosophy). Chalmers University of Technology. School of Architecture. Department of Space and Process. Göteborg. 2000. (91-719-7983-2).

DUARTE, V. M. D. N. O texto descritivo. Brasil Escola, São Paulo, 2016.

ESPINOSA, M. A. et al. Comparing methods for introducing blind and visually impaired people to unfamiliar urban environments. Journal of Environmental Psychology, 1998. 277-287.

FABBRI, R. Música no áudio digital: descrição psicofísica e caixa de ferramentas. 2013. 253 p. Dissertação (Mestrado em Física). Instituto de Física de São Carlos. Universidade de São Paulo - USP. São Carlos. 2013.

FELIPPE, J. A. M. Caminhando juntos: manual das habilidades básicas de orientação e mobilidade. São Paulo: Laramara - Associação Brasileira de Assistência ao Deficiente Visual, 2001.

FELIPPE, J. A. M.; FELIPPE, V. L. R. Orientação e mobilidade. São Paulo: Laramara - Associação Brasileira de Assistência ao Deficiente Visual, 1997. 179 p.

FERNANDES, J. C. Acústica e ruídos. Universidade Estadual Paulista "Júlio de Mesquita Filho" (UNESP). Faculdade de Engenharia. Departamento de Engenharia Mecânica. Laboratório de Acústica e Vibrações (LAV). Bauru, p. 51. 2002.

FLICK, U. Introdução à pesquisa qualitativa. Tradução de Joice Elias Costa. $3^{\text {a }}$. ed. Porto Alegre: Artmed, 2009. ISBN 978-85-363-1711-3.

FOLTZ, M. A. Designing navigable information spaces. 1998. 130 p. Thesis (Master of Science). Department of Electrical Engineering and Computer Science. Massachussetts Institute of Technology. Cambridge. 1998.

FRANCO, E. P. C.; SILVA, M. C. C. C. D. Audiodescrição: breve passeio histórico. In: MOTTA, L. M. V. D. M.; FILHO, P. R. Audiodescrição: transformando imagens em palavras. São Paulo: Secretaria dos Direitos da Pessoa com Deficiência do Estado de São Paulo, 2010. p. 23-42. ISBN 978-854-0470-06.

FUKUHARA, A. C. et al. Benefícios do uso do cão-guia pela pessoa com cegueira. Departamento de Psicologia da Universidade Federal de São Carlos (UFSCar). São Carlos. 2014.

FURRER, M. A. Tipos de barreiras. Acessibilidade na prática, Campo Grande, 16 set. 2012. 
GALITZ, W. O. The essential guide to user interface design: an introduction to GUI design principles and techniques. 3a ed. Indianapolis: Wiley Publishing Inc., 2007. ISBN 978-04-700-5342-3.

GANANÇA, M. M. et al. A vertigem explicada. RBM - Revista Brasileira de Medicina - Especiais, 56, nov 1999. ISSN 0034-7264.

GARCIA, N. Como desenvolver programas de orientação e mobilidade para pessoas com deficiência visual. In: MOTA, M. G. B. Orientação e mobilidade: Conhecimentos básicos para a inclusão do deficiente visual. Brasília: MEC Ministério da Educação, SEESP - Secretaria de Educação Especial, 2003. Cap. 4, p. 66-121.

GIACOMINI, L. Análise de um programa - "passo a passo" orientação e mobilidade para pessoas surdocegas. 2008. 124 f. Dissertação (Mestrado em Psicologia da Educação). Universidade de São Paulo - USP. São Paulo. 2008.

GIACOMINI, L.; SARTORETTO, M. L.; BERSCH, R. D. C. R. A educação especial na perspectiva da inclusão escolar: orientação e mobilidade, adequação postural e acessibilidade espacial. Brasília: Ministério da Educação, v. VII, 2010. ISBN 978-85603-3136-9.

GIBSON, J. J. The ecological approach to visual perception. New York: Taylor \& Francis Group, LLC, 1986. ISBN 978-08-985-9959-6.

GOMES FILHO, J. Gestalt do objeto - sistema de leitura visual da forma. $8^{\mathrm{a}}$. ed. São Paulo: Escrituras Editora, 2008. ISBN 978-85-863-0357-9.

GOOGLE INC. Sobre o Google. Google, 2016.

HANNAH, B.; CONVINTON, G. A. Access by design - a review of universal products. Michigan: Van Nostrand Reinhold, 1997. ISBN 978-04-420-2126-9.

HARPER, S. Standardising electronic travel aid interaction for visually impaired people. 1998. 148 p. Thesis (Master of Philosophy). Institute of Science and Technology. University of Manchester. Manchester. 1998.

HATWELL, Y. Psychologie cognitive de la cécité précoce. 1st. ed. Paris: Dunod, 2003. 213 p. ISBN 978-21-000-6702-2.

HEWETT, T. T. et al. ACM SIGCHI - Curricula for human-computer interaction. New York: ACM, 1992. 162 p. ISBN 978-08-979-1474-1.

HOFFMAN, D. D. Visual intelligence: how we create what we see. New York: Norton, 1998. ISBN 978-03-933-1967-5.

HOFFMANN, S. B. Orientação e mobilidade: um processo de alteração positiva no desenvolvimento integral da criança cega congênita - estudo intercultural entre Brasil e Portugal. 1998. 197 p. Dissertação (Mestrado em Ciências do Movimento Humano). Universidade Federal do Rio Grande do Sul. Escola de Educação Física. Porto Alegre. 1998. 
HULL, J. M. Touching the rock: an experience of blindness. Reprint. ed. New York: Vintage Books, 1992. 218 p. ISBN 978-06-797-3547-2.

IBGE. Censo demográfico 2010: características gerais da população, religião e pessoas com deficiência. Instituto Brasileiro de Geografia e Estatística - IBGE. Brasília. 2012.

IPUF. Manual de acessibilidade. 2aㅗ ed. Florianópolis: IPUF - Instituto de Planejamento Urbano de Florianópolis, 2015. 121 p.

JORDAN, P. W.; PERSSON, S. Exploring users' product constructs: how people think about different types of product. International Journal of CoCreation in Design and the Arts, Leeds, 3, n. suplement 1, 21 may 2007. 97-106. ISSN 1571-0882.

JORIS, P. X.; SCHREINER, C. E.; REES, A. Neural processing of amplitude-modulated sounds. Physiological Reviews, Bethesda, 84, n. 2, 1 Apr 2004. 541-577. ISSN 00319333.

KASTRUP, V. A invenção na ponta dos dedos: a reversão da atenção em pessoas com deficiência visual / (Invention on fingertips: attention reversion in visually impaired people). Psicologia em Revista, Belo Horizonte, v. 13, n. 1, p. 69-90, nov. 2008. ISSN 1678-9563.

KLATZKY, R. L. et al. Cognitive load of navigating without vision when guided by virtual sound versus spatial language. Journal of Experimental Psychology: Applied, Washington, 12, n. 4, 2006. 223-232. ISSN 1076-898X.

KOCH, I. G. V.; TRAVAGLIA, L. C. Texto e coerência. 13a․ ed. Sâo Paulo: Cortez, 2011. ISBN 978-85-249-1679-3.

KULPA, C. C. A contribuição de um modelo de cores na usabilidade das interfaces computacionais para usuários de baixa visão. 2009. 190 p. Dissertação (Mestrado em Design). Universidade Federal do Rio Grande do Sul. Porto Alegre. 2009.

LARA, R.; ALTHAUS, A. P. A inserção da pessoa com deficiência física no mercado de trabalho nas empresas da Grande Florianópolis. VII Seminário de Saúde do Trabalhador e V Seminário 0 Trabalho em Debate, Florianópolis, 2009.

LEITE, J. C. Modelos e formalismos para a engenharia semiótica de interfaces de usuário. 1998. 204 p. Tese (Doutorado em Ciências da Informação). Departamento de Informática. Pontifícia Universidade Católica do Rio de Janeiro PUC Rio. Rio de Janeiro. 1998.

LEVY, W. H. Blindness and the blind: a treatise on the science of typhlology. Londres: Forgotten Books, 2015. 542 p. ISBN 978-13-316-2345-8.

LIBEN, L. S. Conceptual issues in the development of spatial cognition. In: DAVIS, J. S.; KRITCHEVSKY, M.; BELLUGI, U. Spatial Cognition - Brain bases and development. Hillsdale: Lawrence Erlbaum Associates, 1998. p. 167-194. ISBN 978-08-058-0078-4. 
LOCH, R. E. N. Cartografia tátil: mapas para deficienes visuais. Portal da Cartografia, Londrina, 1, n. 1, mai. 2008. 35-58. ISSN 1983-6546.

LODI, J. B. A entrevista: teoria e prática. 8ª . ed. São Paulo: Pioneira, 1998. 176 p. ISBN 85-221-0114-0.

LOOMIS, J. M.; KLATSKY, R. L.; GOLLEDGE, R. G. Navigating without vision: basic and applied research. Optometry and vision science, Santa Barbara, 78, n. 5, may 2001. 282-289.

LORA, T. D. P. Descobrindo o real papel das outras percepções, além da visão, para a orientação e mobilidade. In: MOTA, M. G. B. Orientação e Mobilidade: conhecimentos básicos para a inclusão da pessoa com deficiência visual. Brasília: MEC - Ministério da Educação, SEESP - Secretaria de Educação Especial, 2003. p. 58-65.

LUPTON, E.; PHILLIPS, J. C. Novos fundamentos do design. Tradução de Cristian Borges. 1a. ed. São Paulo: Cosac \& Naify, 2008. ISBN 978-85-750-3239-8.

LYNCH, K. The image of the city. 1‥ ed. Cambridge: The Massachussetts Institute of Technology Press; 1St Edition edition (1960), 1960. 194 p. ISBN 978-02-626-2001-7.

MACE, R. L. What is universal design. Raleigh: The Center for Universal Design. North Carolina State University., v. 19, 1997. 2004 p.

MACHADO, E. V. et al. Orientação e mobilidade: conhecimentos básicos para a inclusão da pessoa com deficiência visual. Brasília: Secretaria de Educação Especial do Ministério da Educação, 2003. 168 p.

MANSINI, E. F. S. O perceber e o relacionar-se do deficiente visual - orientando professores especializados. Revista brasileira de educação especial, Marília, 1, 1992. 29-39. ISSN 1980-5470.

MANSINI, E. F. S. A educação do portador de deficiência visual - as perspectivas do vidente e do não vidente. Em Aberto, Brasília, n. 60, out./dez. 1993. ISSN 01041037.

MARCONI, M. D. A.; LAKATOS, E. M. Técnicas de pesquisa. 6a. ed. São Paulo: Atlas S.A., 2007. 296 p.

MARIANI, E. Delineamento de sistemas eletrônicos para guiar pessoa com deficiência visual em redes de metrô. 2016. 362 p. Dissertação (Mestrado em Arquitetura e Urbanismo). Faculdade de Arquitetura e Urbanismo - FAU. Universidade de São Paulo - USP. São Paulo. 2016.

MASI, I. Conceitos - Aquisição básica para a orientação e mobilidade. In: MOTA, M. G. B. Orientação e Mobilidade: conhecimentos básicos para a inclusão da pessoa com deficiência visual. Brasília: MEC - Ministério da Educação, SEESP - Secretaria de Educação Especial, 2003. p. 38-55. 
MBURU, L. W. Applying user-centered interface design methods to improve the usability of an electronic prescription system. Boca Raton: Universal-Publishers, 2013. 95 p. ISBN 978-16-123-3414-1.

MEDEIROS, E. B. Introdução à teoria acústica. SemEA - Seminário de Engenharia de Áudio, Belo Horizonte, jun 2002.

MINAYO, M. C. D. S.; SANCHES, O. Quantitativo-qualitativo: oposição ou complementaridade? Cadernos de Saúde Pública, Rio de Janeiro, jul.-set. 1993. 239-262. ISSN 1678-4464.

MONICO, J. F. G. Posicionamento pelo NAVSTAR-GPS - descrição, fundamentos e aplicações. São Paulo: Fundação Editora da UNESP, 2000. ISBN 85-713-9328-1.

MONTELLO, D. R.; SAS, C. Human factors of wayfinding in navigation. In: KARWOWSKI, W. International Encyclopedia of Ergonomics and Human Factors. 2nd. ed. Abingdon-on-Thames: CRC Press/Taylor \& Francis, Ltd., 2006. Cap. 394, p. 2003-2008. ISBN 978-04-153-0430-6.

MORAES, M.; ARENDT, R. J. J. Aqui eu sou cego, lá eu sou vidente: modos de ordenar eficiência e deficiência visual. Caderno CH, Salvador, 24, n. 61, jan.- abr 2011. 109-120. ISSN 1983-8239.

MOTA, L. M. V. M.; ROMEU FILHO, P. Audiodescrição - Transformando imagens em palavras. São Paulo: Secretaria estadual dos direitos da pessoa com deficiência, 2010. ISBN 978-85-4047-00-6.

MOURA, G. R. D.; PEDRO, E. N. R. Adolescentes portadores de deficiência visual: percepções sobre sexualidade. Revista latino-americana de enfermagem, Ribeirão Preto, 14, n. 2, mar. 2006. 220-226. ISSN 1518-8345.

MOURO, S.; L.VILELA, C.; NIZA, M. R. E. Caracterização de agressões entre canídeos. Revista Portuguesa de Ciências Veterinárias, Lisboa, CIV, n. 569-572, jan 2009. 61-69.

NETO, N. S. et al. Desenvolvimento de software livre usando reconhecimento e síntese de voz - o estado da arte para o português brasileiro. 6o fórum internacional do software livre - PUC RS, Porto Alegre, jun. 2005.

NOGUEIRA, R. E. Mapas táteis padronizados e acessíveis na web. Instituto Benjamin Constant, Rio de Janeiro, 2009. 16-27.

NORMAN, D. A. O design do dia-a-dia. Tradução de Ana Deiró. Rio de Janeiro: Rocco, 2006. ISBN 85-325-2083-9.

NUNES, E. V.; DANDOLINI, G. A.; SOUZA, J. A. D. As tecnologias assistivas e a pessoa cega. DataGramaZero - Revista de Informação, Rio de Janeiro, 15, n. 1, fev. 2014. ISSN 1517-3801. 
OMS. Relatório mundial sobre a deficiência. Organização Mundial da Saúde. São Paulo: Secretaria de Estado da Pessoa com Deficiência, 2012. ISBN 978-85-6404702-0.

O'SULLIVAN, T. et al. Conceitos-chave em estudos de comunicação e cultura. Piracicaba: Unimep, 2001. ISBN 85-855-4120-2.

PARANHOS, M. Apropriação de espaço por adultos com deficiência visual: estudo de casos. 2008. 140 p. Dissertação (Mestrado em Psicologia Clínica). Núcleo de Psicossomática e Psicologia Hospitalar. Pontifícia Universidade Católica de São Paulo - PUC/SP. São Paulo. 2008.

PARKINSON, B. W.; ENGE, P. K. Progress in astronautics and aeronautics. In: SPILKLER JR., J. J. Global positioning system - theory and applications. Washington: American Institute of Aeronautics and Astronautics, Inc., v. 2, 1996. Cap. 1, p. 3-32.

PENNA, A. G. Psicologia cognitiva e psicolinguística: razão e intuição. Arquivos brasileiros de psicologia, Rio de Janeiro, 3, n. 39, jul.-set. 1987. 36-43. ISSN 01008692.

PRADO, T. D. D. et al. Técnicas de imobilização de mandíbulas de cães e gatos: Revisão de literatura. Medvep - Revista Científica de Medicina Veterinária Pequenos Animais e Animais de Estimação, Curitiba, n. 31, 2011. 600-605.

QUARESMA, M.; MORAES, A. D. A usabilidade em sistemas de navegação GPS. Anais do XV Congresso Brasileiro de Ergonomia, VI Fórum Brasileiro de Ergonomia, Porto Seguro, 2008.

RAMOS, J. J. C. Acessibilidade para a pessoa com cegueira em trilhas. 2009. 104 p. Dissertação (Mestrado em Educação Especial). Programa de Pós-Graduação em Educação Especial. Centro de Educação e Ciências Humanas. Universidade Federal de São Carlos. São Carlos. 2009.

REDIG, J. Não há cidadania sem informação, nem informação sem design. InfoDesign - Revista brasileira de design da informação, Recife, 1, n. 1, 2004. 51-59. ISSN 1808-5377.

RIBEIRO, S. B. et al. Características da marcha em sujeitos com deficiência visual. Revista Terapia manual, 8, n. 35, jan-fev 2010. 27-32. ISSN 1677-5937.

ROCHA, C.; ZANETTI, B. Engenharia semiótica e affordances: portal web UFG. Proceedings of World Congress on Communication and Arts, Geolong, 04-07 jul. 2012. 66-68. ISSN 2317-1707.

ROCHA, H. V.; BARANAUSKAS, M. C. C. Design e avaliação de interfaces humanocomputador. Campinas: Nied/Unicamp, 2003. ISBN 978-85-888-3304-3.

RODRIGUES, R. F. L.; FIGUEIREDO, M. F. Prosódia e pragmática: um estudo retórico de palestras motivacionais. Diálogos Pertinentes - Revista Científica de Letras, Franca, 6, n. 1, jan.-jun. 2010. 89-104. ISSN 2177-9856. 
ROGERS, Y.; SHARP, H.; PREECE, J. Design de interação - além da interação homem-computador. Tradução de Isabela Gasparini. 3ạ. ed. Porto Alegre: Bookman, 2013. 585 p. ISBN 978-85-826-0006-1.

RUI, L. R.; STEFFANI, M. H. Fisica: som e audição humana. XVII Simpósio Nacional de Ensino de Física, São Luis, jan-fev 2007.

RUSCHEL, H.; ZANOTTO, M. S.; MOTA, W. C. Computação em nuvem. Especialização em Redes e Segurança de Sistemas, Curitiba, Abril 2010.

SÁ, E. D.; CAMPOS, I. M.; SILVA, M. B. C. Atendimento educacional especializado deficiência visual. Brasília: Ministério da Educação e Cultura - MEC, 2007.

SACKS, O. Alucinações musicais: Relatos sobre a música e o cérebro. Tradução de Laura Teixeira Motta. São Paulo: Companhia das Letras, 2007. ISBN 978-85-3591091-9.

SACKS, 0. W. O olhar da mente. Tradução de Laura Teixeira Motta. São Paulo: Editora Companhia das Letras, 2010. ISBN 978-85-359-1769-7.

SANTOS, A. J. D. O.; CASTRO, S. A. Autoestima a partir do caminhar - orientação e mobilidade da pessoa com deficiência visual. Revista Benjamin Constant, Rio de Janeiro, n. 54, abr. 2013. ISSN 1984-6061.

SANTOS, V. S. Cinco sentidos. Brasil escola, São Paulo, 2016.

SARRAF, V. P. A Comunicação dos sentidos nos espaços culturais brasileiros: estratégias de mediações e acessibilidade para as pessoas com suas diferenças. 251 p. Tese (Doutorado em Comunicação e Semiótica). Programa de pós-graduação em Comunicação e Semiótica. Pontifícia Universidade Católica de São Paulo - PUC-SP. São Paulo, p. 251. 2013.

SCHIFFMAN, H. R. Sensação e percepção. 5a. ed. Rio de Janeiro: LTC, 2005. ISBN 978-85-216-1445-6.

SCHMIDT, M. A. R.; DELAZARI, L. S. Proposta de metodologia para testes qualitativos de mapas 3D. Boletim de Ciências Geodésicas, Curitiba, 16, n. 4, outdez 2010. 575-588.

SILVEIRA, C. M. Professores de alunos com deficiência visual - saberes, competências e capacitação. 2010. 137 p. Dissertação (Mestrado em Educação). Faculdade de Educação. Pontifícia Universidade Católica do Rio Grande do Sul. Porto Alegre. 2010.

SOARES, R. Avaliação dos condutores portadores de discromatopsia congênita na percepção cromática da sinalização viária. 2009. 145 p. Dissertação (Mestrado em Transportes). Departamento de Engenharia Civil e Ambiental. Faculdade de Tecnologia. Universidade de Brasília. Brasília. 2009. 
SPADA, A. L. O ouvido humano. Artigos Técnicos da Attack do Brasil, Apucarana, 2015.

SVOX MOBILE VOICES. Luciana TTS. Zurich. 2010.

THIRY-CHERQUES, H. R. Saturação em pesquisa qualitativa: estimativa empírica de dimensionamento. PMKT - Revista Brasileira de Pesquisas de Marketing, Opinião e Mídia, São Paulo, n. 3, 10 set 2009. 20-27. ISSN 1983-9456.

TREUILLET, S. et al. Body mounted vision system for visually impaired - outdoor and indoor wayfinding assistance. Conference \& Workshop on Assistive Technologies for People with Vision \& Hearing Impairments Assistive Technology for All Ages, Granada, 28-31 aug 2007.

TURTLE, D.; TURTLE, N. Richard Edwin Hoover. Hall of Fame: leaders and legends of the blindness field, Louisville, 2002.

VALENTINE, D.; KIDDOO, M.; LAFLEUR, B. Psychosocial implications of service dog ownership for people who have mobility or hearing impairments. Social Work in Health Care, New York, 19, n. 1, 26 oct. 2008. 109-125. ISSN 0098-1389.

WATANABE, R. M. Existe algum padrão para placas de rua? Placa de Rua, Campinas, 2009.

WELLENHOF, B. H.; LICHTENEGGER, H.; COLLINS, J. Global positioning system Theory and practice. 5th. ed. New York: Springer-Verlag, v. 1, 2013. ISBN 978-32118-3534-0.

WHO. Management of low vision in children. $52 f$. World Health Organization. Bangkok. 1992.

ZHENG, P.; NI, L. M. Spotlight: the rise of the smart phone. IEEE Distribuited Systems Online, Los Alamitos, 7, mar. 2006. ISSN 1541-4922. 



\section{APÊNDICE A: PROTOCOLO DAS ENTREVISTAS SEMIESTRUTURADAS}

- Local: Associação para Deficientes Visuais e Amigos (ADEVA).

○ Por quê? Por aceite do convite para contribuir com a pesquisa.

- Quem: pessoas com deficiência visual convidadas pela ADEVA.

- Critério de seleção solicitado à ADEVA: amostragem intencional, pessoas adultas e que possuem autonomia em orientação e mobilidade.

- Categorização: pelo grau de deficiência visual (cegueira ou baixa visão) e pela presença de memória visual (pessoas com deficiência congênita ou com deficiência adquirida).

- Quantidade: definida pelo critério de saturação dos dados, totalizando seis entrevistados.

- Quando: ao longo do mês de setembro de 2015.

- Como: convidados por meio de telefonema e e-mail.

- Para que: para discutir aspectos de linguagens por construções verbais a serem inseridos em equipamentos eletrônicos portáteis para guiar pessoas com deficiência visual em locais públicos.

- Ferramentas: lápis e papel, gravador de som digital e questionário representado pelo quadro 18, página 194, introduzido durante entrevistas semiestruturadas. 
Quadro 18 - Conteúdo de questões sobre a interface vocal

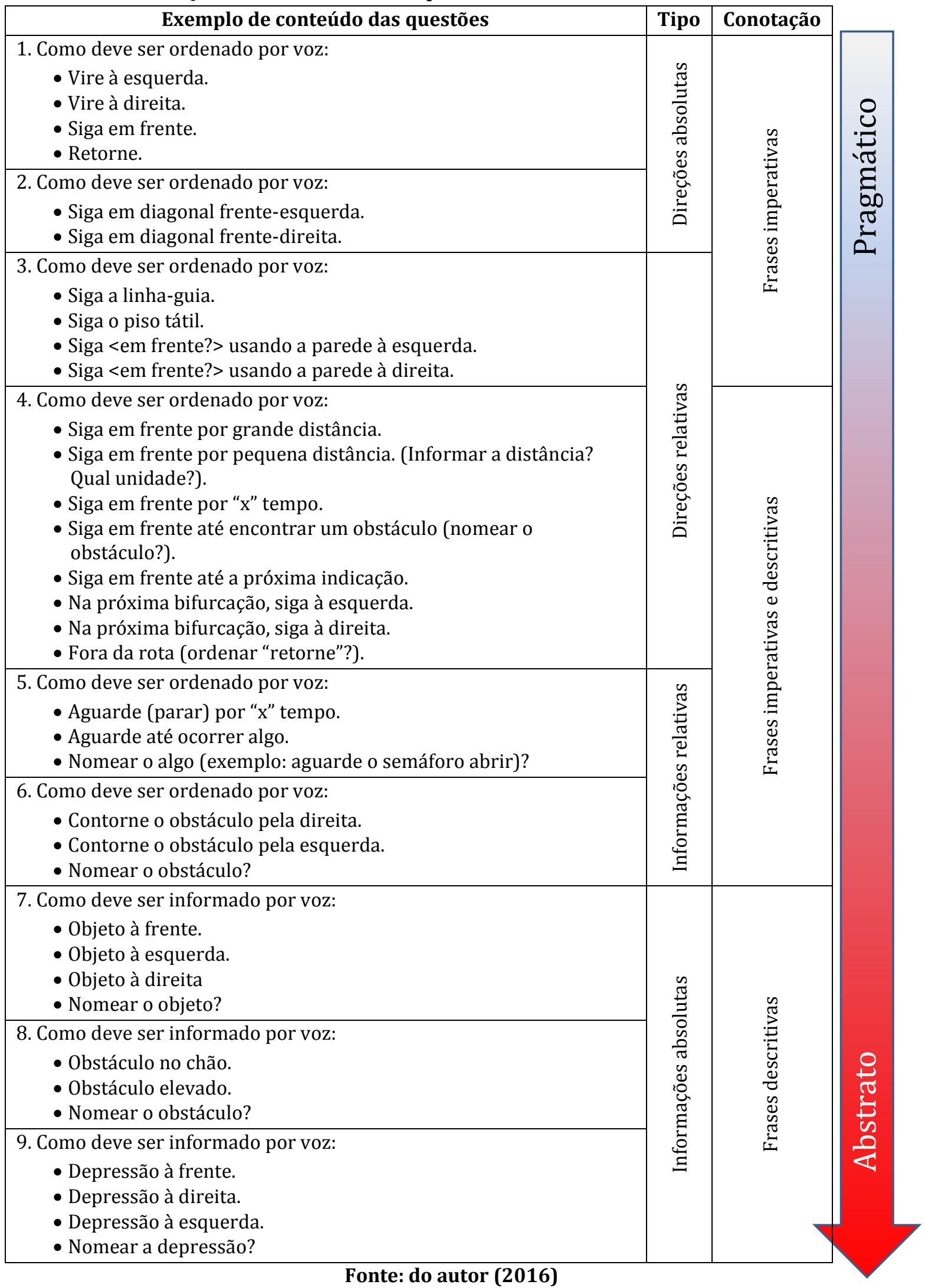




\section{APÊNDICE B: RESPOSTAS OBTIDAS NAS ENTREVISTAS SEMIESTRUTURADAS}

Quadro 19 - Respostas do entrevistado “CF”

\begin{tabular}{|c|c|}
\hline Perguntas & Respostas \\
\hline $\begin{array}{l}\text { 1. Como deve ser ordenado por voz: } \\
\text { - Vire à esquerda. } \\
\text { - Vire à direita. } \\
\text { - Siga em frente. } \\
\text { - Retorne. }\end{array}$ & $\begin{array}{l}\text { - Esquerda. } \\
\text { - Direita. } \\
\text { - Siga. } \\
\text { - Retorne. }\end{array}$ \\
\hline $\begin{array}{l}\text { 2. Como deve ser ordenado por voz: } \\
\text { - Siga em diagonal frente-esquerda. } \\
\text { • Siga em diagonal frente-direita. }\end{array}$ & • Não usa diagonal. \\
\hline $\begin{array}{l}\text { 3. Como deve ser ordenado por voz: } \\
\text { - Siga a linha guia. } \\
\text { - Siga o piso tátil. } \\
\text { - Siga <em frente?> usando a parede à } \\
\text { esquerda. } \\
\text { - Siga < em frente?> usando a parede à direita. }\end{array}$ & $\begin{array}{l}\text { - Se a linha guia for piso tátil, usar } \\
\text { "siga". } \\
\text { - Se a linha guia não for piso tátil, } \\
\text { descrever a linha guia (siga a } \\
\text { parede à esquerda, siga a } \\
\text { mureta à direita, etc.) }\end{array}$ \\
\hline $\begin{array}{l}\text { 4. Como deve ser ordenado por voz: } \\
\text { - Siga em frente por grande distância. } \\
\text { - Siga em frente por pequena distância. } \\
\text { (Informar a distância? Qual unidade?). } \\
\text { - Siga em frente por "x" tempo. } \\
\text { - Siga em frente até encontrar um obstáculo } \\
\text { (nomear o obstáculo?). } \\
\text { - Siga em frente até a próxima indicação. } \\
\text { - Na próxima bifurcação, siga à esquerda. } \\
\text { - Na próxima bifurcação, siga à direita. } \\
\text { - Fora da rota (ordenar "retorne"?). }\end{array}$ & $\begin{array}{l}\text { - Para longas distâncias, usar } \\
\text { metros ou passos para indicar } \\
\text { uma idéia de "longe". Para } \\
\text { pequenas distâncias, somente } \\
\text { direcionar, não usar unidades. }\end{array}$ \\
\hline $\begin{array}{l}\text { 5. Como deve ser ordenado por voz: } \\
\text { - Aguarde (parar) por "x" tempo. } \\
\text { - Aguarde até ocorrer algo. } \\
\text { - Nomear o algo (exemplo: aguarde o semáforo } \\
\text { abrir)? }\end{array}$ & $\begin{array}{l}\text { - Não citar tempo, pois a } \\
\text { percepção se perde. } \\
\text { - Se usar piso tátil, não precisa } \\
\text { nomear previamente o destino. }\end{array}$ \\
\hline $\begin{array}{l}\text { 6. Como deve ser ordenado por voz: } \\
\text { - Contorne o obstáculo pela direita. } \\
\text { - Contorne o obstáculo pela esquerda. } \\
\text { - Nomear o obstáculo? }\end{array}$ & $\begin{array}{l}\text { - Descrever o obstáculo, a pessoa } \\
\text { escolhe o que irá fazer. }\end{array}$ \\
\hline $\begin{array}{l}\text { 7. Como deve ser informado por voz: } \\
\text { - Objeto à frente. } \\
\text { - Objeto à esquerda. } \\
\text { - Objeto à direita } \\
\text { - Nomear o objeto? }\end{array}$ & $\begin{array}{l}\text { - Informar da presença do objeto. } \\
\text { Descrever o objeto. }\end{array}$ \\
\hline $\begin{array}{l}\text { 8. Como deve ser informado por voz: } \\
\text { - Obstáculo no chão. } \\
\text { - Obstáculo elevado. } \\
\text { - Nomear o obstáculo? }\end{array}$ & $\begin{array}{l}\text { - Informar da presença de risco } \\
\text { elevado, ou de obstáculo. } \\
\text { - Se houver impedimento, } \\
\text { descrever. }\end{array}$ \\
\hline $\begin{array}{l}\text { 9. Como deve ser informado por voz: } \\
\text { - Depressão à frente. } \\
\text { - Depressão à direita. } \\
\text { - Depressão à esquerda. } \\
\text { - Nomear a depressão? }\end{array}$ & - Informar que há risco de queda. \\
\hline
\end{tabular}

Fonte: do autor (2015) 
Quadro 20 - Respostas do entrevistado "MC"

\begin{tabular}{|c|c|}
\hline Perguntas & Respostas \\
\hline $\begin{array}{l}\text { 1. Como deve ser ordenado por voz: } \\
\text { - Vire à esquerda. } \\
\text { - Vire à direita. } \\
\text { - Siga em frente. } \\
\text { - Retorne. }\end{array}$ & $\begin{array}{l}\text { - Esquerda. } \\
\text { - Direita. } \\
\text { - Siga. } \\
\text { - Retorne. }\end{array}$ \\
\hline $\begin{array}{l}\text { 2. Como deve ser ordenado por voz: } \\
\text { - Siga em diagonal frente-esquerda. } \\
\text { - Siga em diagonal frente-direita. }\end{array}$ & • Não usa diagonal. \\
\hline $\begin{array}{l}\text { 3. Como deve ser ordenado por voz: } \\
\text { - Siga a linha guia. } \\
\text { - Siga o piso tátil. } \\
\text { - Siga <em frente?> usando a parede à } \\
\text { esquerda. } \\
\text { - Siga <em frente?> usando a parede à direita. }\end{array}$ & $\begin{array}{l}\text { - Se a linha guia for piso tátil, usar } \\
\text { "siga". } \\
\text { - Se a linha guia não for piso tátil, } \\
\text { descrever a linha guia (siga a } \\
\text { parede à esquerda, siga a mureta à } \\
\text { direita, etc.) }\end{array}$ \\
\hline $\begin{array}{l}\text { 4. Como deve ser ordenado por voz: } \\
\text { - Siga em frente por grande distância. } \\
\text { - Siga em frente por pequena distância. } \\
\text { (Informar a distância? Qual unidade?). } \\
\text { - Siga em frente por "x" tempo. } \\
\text { - Siga em frente até encontrar um obstáculo } \\
\text { (nomear o obstáculo?). } \\
\text { - Siga em frente até a próxima indicação. } \\
\text { - Na próxima bifurcação, siga à esquerda. } \\
\text { - Na próxima bifurcação, siga à direita. } \\
\text { - Fora da rota (ordenar "retorne"?). }\end{array}$ & $\begin{array}{l}\text { - Dizer somente "siga”, não informar } \\
\text { unidade de distância nem unidade } \\
\text { de tempo. Informar quando estiver } \\
\text { chegando a um obstáculo. } \\
\text { - Para longas distâncias, não usar } \\
\text { passos nem metros. Para pequenas } \\
\text { distâncias, usar passos (até dois } \\
\text { passos). }\end{array}$ \\
\hline $\begin{array}{l}\text { 5. Como deve ser ordenado por voz: } \\
\text { - Aguarde (parar) por "x" tempo. } \\
\text { - Aguarde até ocorrer algo. } \\
\text { - Nomear o algo (exemplo: aguarde o semáforo } \\
\text { abrir)? }\end{array}$ & $\begin{array}{l}\text { - Não citar tempo, pois a percepção } \\
\text { se perde. } \\
\text { - Se usar piso tátil, não precisa } \\
\text { nomear previamente o destino. }\end{array}$ \\
\hline $\begin{array}{l}\text { 6. Como deve ser ordenado por voz: } \\
\text { - Contorne o obstáculo pela direita. } \\
\text { - Contorne o obstáculo pela esquerda. } \\
\text { • Nomear o obstáculo? }\end{array}$ & $\begin{array}{l}\text { - Descrever o obstáculo, a pessoa } \\
\text { escolhe o que irá fazer. }\end{array}$ \\
\hline $\begin{array}{l}\text { 7. Como deve ser informado por voz: } \\
\text { - Objeto à frente. } \\
\text { - Objeto à esquerda. } \\
\text { - Objeto à direita } \\
\text { - Nomear o objeto? }\end{array}$ & $\begin{array}{l}\text { - Descrever o objeto e informar onde } \\
\text { está. }\end{array}$ \\
\hline $\begin{array}{l}\text { 8. Como deve ser informado por voz: } \\
\text { - Obstáculo no chão. } \\
\text { - Obstáculo elevado. } \\
\text { - Nomear o obstáculo? }\end{array}$ & $\begin{array}{l}\text { - Informar da presença de risco } \\
\text { elevado, ou de obstáculo. } \\
\text { - Se houver impedimento, descrever. }\end{array}$ \\
\hline $\begin{array}{l}\text { 9. Como deve ser informado por voz: } \\
\text { - Depressão à frente. } \\
\text { - Depressão à direita. } \\
\text { - Depressão à esquerda. } \\
\text { - Nomear a depressão? }\end{array}$ & - Informar que há risco de queda. \\
\hline
\end{tabular}


Quadro 21 - Respostas da entrevistada "MI"

\begin{tabular}{|c|c|}
\hline Perguntas & Respostas \\
\hline $\begin{array}{l}\text { 1. Como deve ser ordenado por voz: } \\
\text { - Vire à esquerda. } \\
\text { - Vire à direita. } \\
\text { - Siga em frente. } \\
\text { - Retorne. }\end{array}$ & $\begin{array}{l}\text { - Esquerda. } \\
\text { - Direita. } \\
\text { - Siga. } \\
\text { - Retorne. }\end{array}$ \\
\hline $\begin{array}{l}\text { 2. Como deve ser ordenado por voz: } \\
\text { - Siga em diagonal frente-esquerda. } \\
\text { - Siga em diagonal frente-direita. }\end{array}$ & • Não usa diagonal. \\
\hline $\begin{array}{l}\text { 3. Como deve ser ordenado por voz: } \\
\text { - Siga a linha guia. } \\
\text { - Siga o piso tátil. } \\
\text { - Siga <em frente?> usando a parede à } \\
\text { esquerda. } \\
\text { - Siga <em frente?> usando a parede à direita. }\end{array}$ & $\begin{array}{l}\text { - Se a linha guia for piso tátil, usar } \\
\text { "siga". } \\
\text { - Se a linha guia não for piso tátil, } \\
\text { descrever a linha guia (siga a } \\
\text { parede à esquerda, siga a } \\
\text { mureta à direita, etc.) }\end{array}$ \\
\hline $\begin{array}{l}\text { 4. Como deve ser ordenado por voz: } \\
\text { - Siga em frente por grande distância. } \\
\text { - Siga em frente por pequena distância. } \\
\text { (Informar a distância? Qual unidade?). } \\
\text { - Siga em frente por "x" tempo. } \\
\text { - Siga em frente até encontrar um obstáculo } \\
\text { (nomear o obstáculo?). } \\
\text { - Siga em frente até a próxima indicação. } \\
\text { - Na próxima bifurcação, siga à esquerda. } \\
\text { - Na próxima bifurcação, siga à direita. } \\
\text { - Fora da rota (ordenar "retorne"?). }\end{array}$ & $\begin{array}{l}\text { - Dizer somente “siga", não } \\
\text { informar unidade de distância } \\
\text { nem unidade de tempo. } \\
\text { Informar quando estiver } \\
\text { chegando a um obstáculo. } \\
\text { - Para longas distâncias, não usar } \\
\text { passos nem metros. Para } \\
\text { pequenas distâncias, usar } \\
\text { passos (até dois passos). Prever } \\
\text { o tamanho da bengala para } \\
\text { pequenas distâncias. }\end{array}$ \\
\hline $\begin{array}{l}\text { 5. Como deve ser ordenado por voz: } \\
\text { - Aguarde (parar) por "x" tempo. } \\
\text { - Aguarde até ocorrer algo. } \\
\text { - Nomear o algo (exemplo: aguarde o semáforo } \\
\text { abrir)? }\end{array}$ & $\begin{array}{l}\text { - Não citar tempo, pois a } \\
\text { percepção se perde. } \\
\text { - Se usar piso tátil, não precisa } \\
\text { nomear previamente o destino. }\end{array}$ \\
\hline $\begin{array}{l}\text { 6. Como deve ser ordenado por voz: } \\
\text { - Contorne o obstáculo pela direita. } \\
\text { - Contorne o obstáculo pela esquerda. } \\
\text { - Nomear o obstáculo? }\end{array}$ & $\begin{array}{l}\text { - Descrever o obstáculo, a pessoa } \\
\text { escolhe o que irá fazer. }\end{array}$ \\
\hline $\begin{array}{l}\text { 7. Como deve ser informado por voz: } \\
\text { - Objeto à frente. } \\
\text { - Objeto à esquerda. } \\
\text { - Objeto à direita } \\
\text { - Nomear o objeto? }\end{array}$ & $\begin{array}{l}\text { - Informar da presença do objeto. } \\
\text { Descrever o objeto. }\end{array}$ \\
\hline $\begin{array}{l}\text { 8. Como deve ser informado por voz: } \\
\text { - Obstáculo no chão. } \\
\text { - Obstáculo elevado. } \\
\text { - Nomear o obstáculo? }\end{array}$ & $\begin{array}{l}\text { - Informar da presença de risco } \\
\text { elevado, ou de obstáculo. } \\
\text { - Se houver impedimento, } \\
\text { descrever. }\end{array}$ \\
\hline $\begin{array}{l}\text { 9. Como deve ser informado por voz: } \\
\text { - Depressão à frente. } \\
\text { - Depressão à direita. } \\
\text { - Depressão à esquerda. } \\
\text { - Nomear a depressão? }\end{array}$ & - Informar que há risco de queda. \\
\hline
\end{tabular}

Fonte: do autor (2015) 
Quadro 22 - Respostas do entrevistado "MK"

\begin{tabular}{|c|c|}
\hline Perguntas & Respostas \\
\hline $\begin{array}{l}\text { 1. Como deve ser ordenado por voz: } \\
\text { - Vire à esquerda. } \\
\text { - Vire à direita. } \\
\text { - Siga em frente. } \\
\text { - Retorne. }\end{array}$ & $\begin{array}{l}\text { - Esquerda. } \\
\text { - Direita. } \\
\text { - Siga. } \\
\text { - Retorne. }\end{array}$ \\
\hline $\begin{array}{l}\text { 2. Como deve ser ordenado por voz: } \\
\text { - Siga em diagonal frente-esquerda. } \\
\text { - Siga em diagonal frente-direita. }\end{array}$ & - Não usa diagonal. \\
\hline $\begin{array}{l}\text { 3. Como deve ser ordenado por voz: } \\
\text { - Siga a linha guia. } \\
\text { - Siga o piso tátil. } \\
\text { - Siga <em frente?> usando a parede à esquerda. } \\
\text { - Siga <em frente?> usando a parede à direita. }\end{array}$ & - Não descrever a linha guia. \\
\hline $\begin{array}{l}\text { 4. Como deve ser ordenado por voz: } \\
\text { - Siga em frente por grande distância. } \\
\text { - Siga em frente por pequena distância. (Informar } \\
\text { a distância? Qual unidade?). } \\
\text { - Siga em frente por "x" tempo. } \\
\text { - Siga em frente até encontrar um obstáculo } \\
\text { (nomear o obstáculo?). } \\
\text { - Siga em frente até a próxima indicação. } \\
\text { - Na próxima bifurcação, siga à esquerda. } \\
\text { - Na próxima bifurcação, siga à direita. } \\
\text { - Fora da rota (ordenar "retorne"?). }\end{array}$ & $\begin{array}{l}\text { - Dizer somente “siga”, não } \\
\text { informar unidade de distância } \\
\text { nem unidade de tempo. } \\
\text { Informar quando estiver } \\
\text { chegando a um obstáculo. } \\
\text { - Para pequenas distâncias, só } \\
\text { informar a direção. }\end{array}$ \\
\hline $\begin{array}{l}\text { 5. Como deve ser ordenado por voz: } \\
\text { - Aguarde (parar) por "x" tempo. } \\
\text { - Aguarde até ocorrer algo. } \\
\text { - Nomear o algo (exemplo: aguarde o semáforo } \\
\text { abrir)? }\end{array}$ & $\begin{array}{l}\text { - Não citar tempo, pois a } \\
\text { percepção se perde. } \\
\text { - Se usar piso tátil, não precisa } \\
\text { nomear previamente o destino. }\end{array}$ \\
\hline $\begin{array}{l}\text { 6. Como deve ser ordenado por voz: } \\
\text { - Contorne o obstáculo pela direita. } \\
\text { - Contorne o obstáculo pela esquerda. } \\
\text { - Nomear o obstáculo? }\end{array}$ & $\begin{array}{l}\text { - Descrever o obstáculo, a pessoa } \\
\text { escolhe o que irá fazer. }\end{array}$ \\
\hline $\begin{array}{l}\text { 7. Como deve ser informado por voz: } \\
\text { - Objeto à frente. } \\
\text { - Objeto à esquerda. } \\
\text { - Objeto à direita } \\
\text { - Nomear o objeto? }\end{array}$ & $\begin{array}{l}\text { - Informar da presença do objeto. } \\
\text { Descrever o objeto. }\end{array}$ \\
\hline $\begin{array}{l}\text { 8. Como deve ser informado por voz: } \\
\text { - Obstáculo no chão. } \\
\text { • Obstáculo elevado. } \\
\text { - Nomear o obstáculo? }\end{array}$ & $\begin{array}{l}\text { - Informar da presença de risco } \\
\text { elevado, ou de obstáculo. } \\
\text { - Se houver impedimento, } \\
\text { descrever. }\end{array}$ \\
\hline $\begin{array}{l}\text { 9. Como deve ser informado por voz: } \\
\text { - Depressão à frente. } \\
\text { - Depressão à direita. } \\
\text { - Depressão à esquerda. } \\
\text { - Nomear a depressão? }\end{array}$ & - Informar que há risco de queda. \\
\hline
\end{tabular}

Fonte: do autor (2015) 
Quadro 23 - Respostas do entrevistado "RB"

\begin{tabular}{|c|c|}
\hline Perguntas & Respostas \\
\hline $\begin{array}{l}\text { 1. Como deve ser ordenado por voz: } \\
\text { - Vire à esquerda. } \\
\text { - Vire à direita. } \\
\text { - Siga em frente. } \\
\text { - Retorne. }\end{array}$ & $\begin{array}{l}\text { - Esquerda. } \\
\text { - Direita. } \\
\text { - Siga. } \\
\text { - Retorne. }\end{array}$ \\
\hline $\begin{array}{l}\text { 2. Como deve ser ordenado por voz: } \\
\text { - Siga em diagonal frente-esquerda. } \\
\text { - Siga em diagonal frente-direita. }\end{array}$ & • Não usa diagonal. \\
\hline $\begin{array}{l}\text { 3. Como deve ser ordenado por voz: } \\
\text { - Siga a linha-guia. } \\
\text { - Siga o piso tátil. } \\
\text { - Siga <em frente?> usando a parede à esquerda. } \\
\text { - Siga <em frente?> usando a parede à direita. }\end{array}$ & $\begin{array}{l}\text { - Se a linha guia for piso tátil, usar } \\
\text { "siga". } \\
\text { - Descrever a linha guia se esta não } \\
\text { for piso tátil (siga a parede à } \\
\text { esquerda, siga a mureta à direita, } \\
\text { etc.) }\end{array}$ \\
\hline $\begin{array}{l}\text { 4. Como deve ser ordenado por voz: } \\
\text { - Siga em frente por grande distância. } \\
\text { - Siga em frente por pequena distância. (Informar } \\
\text { a distância? Qual unidade?). } \\
\text { - Siga em frente por "x" tempo. } \\
\text { - Siga em frente até encontrar um obstáculo } \\
\text { (nomear o obstáculo?). } \\
\text { - Siga em frente até a próxima indicação. } \\
\text { - Na próxima bifurcação, siga à esquerda. } \\
\text { - Na próxima bifurcação, siga à direita. } \\
\text { - Fora da rota (ordenar "retorne"?). } \\
\end{array}$ & $\begin{array}{l}\text { - Dizer somente "siga", não informar } \\
\text { unidade de distância nem unidade } \\
\text { de tempo. Informar quando estiver } \\
\text { chegando a um obstáculo. } \\
\text { - Para longas distâncias, não usar } \\
\text { passos nem metros. Para pequenas } \\
\text { distâncias, usar passos (até dois } \\
\text { passos). }\end{array}$ \\
\hline $\begin{array}{l}\text { 5. Como deve ser ordenado por voz: } \\
\text { - Aguarde (parar) por "x" tempo. } \\
\text { - Aguarde até ocorrer algo. } \\
\text { - Nomear o algo (exemplo: aguarde o semáforo } \\
\text { abrir)? }\end{array}$ & $\begin{array}{l}\text { - Não citar tempo, pois a percepção } \\
\text { se perde. } \\
\text { - Se usar piso tátil, não precisa } \\
\text { nomear previamente o destino. }\end{array}$ \\
\hline $\begin{array}{l}\text { 6. Como deve ser ordenado por voz: } \\
\text { - Contorne o obstáculo pela direita. } \\
\text { - Contorne o obstáculo pela esquerda. } \\
\text { - Nomear o obstáculo? }\end{array}$ & $\begin{array}{l}\text { - Descrever o obstáculo, a pessoa } \\
\text { escolhe o que irá fazer. }\end{array}$ \\
\hline $\begin{array}{l}\text { 7. Como deve ser informado por voz: } \\
\text { - Objeto à frente. } \\
\text { - Objeto à esquerda. } \\
\text { - Objeto à direita } \\
\text { - Nomear o objeto? }\end{array}$ & $\begin{array}{l}\text { - Descrever o objeto e informar onde } \\
\text { está. }\end{array}$ \\
\hline $\begin{array}{l}\text { 8. Como deve ser informado por voz: } \\
\text { • Obstáculo no chão. } \\
\text { • Obstáculo elevado. } \\
\text { • Nomear o obstáculo? }\end{array}$ & $\begin{array}{l}\text { - Informar da presença de risco } \\
\text { elevado, ou de obstáculo. } \\
\text { - Se houver impedimento, descrever. }\end{array}$ \\
\hline $\begin{array}{l}\text { 9. Como deve ser informado por voz: } \\
\text { - Depressão à frente. } \\
\text { - Depressão à direita. } \\
\text { - Depressão à esquerda. } \\
\text { - Nomear a depressão? }\end{array}$ & - Informar que há risco de queda. \\
\hline
\end{tabular}


Quadro 24 - Respostas do entrevistado "SE"

\begin{tabular}{|c|c|}
\hline Perguntas & Respostas \\
\hline $\begin{array}{l}\text { 1. Como deve ser ordenado por voz: } \\
\text { - Vire à esquerda. } \\
\text { - Vire à direita. } \\
\text { - Siga em frente. } \\
\text { - Retorne. }\end{array}$ & $\begin{array}{l}\text { - Esquerda. } \\
\text { - Direita. } \\
\text { - Siga. } \\
\text { - Retorne. }\end{array}$ \\
\hline $\begin{array}{l}\text { 2. Como deve ser ordenado por voz: } \\
\text { - Siga em diagonal frente-esquerda. } \\
\text { - Siga em diagonal frente-direita. } \\
\end{array}$ & • Não usa diagonal. \\
\hline $\begin{array}{l}\text { 3. Como deve ser ordenado por voz: } \\
\text { - Siga a linha guia. } \\
\text { - Siga o piso tátil. } \\
\text { - Siga <em frente?> usando a parede à } \\
\text { esquerda. } \\
\text { - Siga <em frente?> usando a parede à direita. }\end{array}$ & $\begin{array}{l}\text { - Se a linha guia for piso tátil, usar "siga } \\
\text { o piso tátil". O cão-guia segue o piso } \\
\text { tátil. } \\
\text { - Se a linha guia não for piso tátil, } \\
\text { descrever a linha guia (siga a parede à } \\
\text { esquerda, siga a mureta à direita, etc.) }\end{array}$ \\
\hline $\begin{array}{l}\text { 4. Como deve ser ordenado por voz: } \\
\text { - Siga em frente por grande distância. } \\
\text { - Siga em frente por pequena distância. } \\
\text { (Informar a distância? Qual unidade?). } \\
\text { - Siga em frente por "x" tempo. } \\
\text { - Siga em frente até encontrar um obstáculo } \\
\text { (nomear o obstáculo?). } \\
\text { - Siga em frente até a próxima indicação. } \\
\text { - Na próxima bifurcação, siga à esquerda. } \\
\text { - Na próxima bifurcação, siga à direita. } \\
\text { - Fora da rota (ordenar "retorne"?). } \\
\end{array}$ & $\begin{array}{l}\text { - Dizer somente "siga", não informar } \\
\text { unidade de distância nem unidade de } \\
\text { tempo. Informar quando estiver } \\
\text { chegando a um obstáculo. } \\
\text { - Para pequenas distâncias, indicar a } \\
\text { direção. }\end{array}$ \\
\hline $\begin{array}{l}\text { 5. Como deve ser ordenado por voz: } \\
\text { - Aguarde (parar) por "x" tempo. } \\
\text { - Aguarde até ocorrer algo. } \\
\text { - Nomear o algo (exemplo: aguarde o semáforo } \\
\text { abrir)? }\end{array}$ & $\begin{array}{l}\text { - Não citar tempo, pois a percepção se } \\
\text { perde. } \\
\text { - Se usar piso tátil, não precisa nomear } \\
\text { previamente o destino. }\end{array}$ \\
\hline $\begin{array}{l}\text { 6. Como deve ser ordenado por voz: } \\
\text { - Contorne o obstáculo pela direita. } \\
\text { • Contorne o obstáculo pela esquerda. } \\
\text { • Nomear o obstáculo? } \\
\end{array}$ & $\begin{array}{l}\text { - Descrever o obstáculo, a pessoa } \\
\text { escolhe o que irá fazer. }\end{array}$ \\
\hline $\begin{array}{l}\text { 7. Como deve ser informado por voz: } \\
\text { - Objeto à frente. } \\
\text { - Objeto à esquerda. } \\
\text { - Objeto à direita } \\
\text { - Nomear o objeto? }\end{array}$ & $\begin{array}{l}\text { - Informar da presença do objeto. } \\
\text { Descrever o objeto. }\end{array}$ \\
\hline $\begin{array}{l}\text { 8. Como deve ser informado por voz: } \\
\text { - Obstáculo no chão. } \\
\text { • Obstáculo elevado. } \\
\text { • Nomear o obstáculo? }\end{array}$ & $\begin{array}{l}\text { - Informar da presença de risco elevado, } \\
\text { ou de obstáculo. } \\
\text { - Se houver impedimento, descrever. }\end{array}$ \\
\hline $\begin{array}{l}\text { 9. Como deve ser informado por voz: } \\
\text { - Depressão à frente. } \\
\text { - Depressão à direita. } \\
\text { - Depressão à esquerda. } \\
\text { - Nomear a depressão? }\end{array}$ & - Informar que há risco de queda. \\
\hline
\end{tabular}

Fonte: do autor (2015) 


\section{APÊNDICE C: PROTOCOLO DO EXPERIMENTO PRÁTICO EM LOCAL CONTROLADO}

- Local: Associação para Deficientes Visuais e Amigos (ADEVA).

○ Por quê? Por aceite do convite para contribuir com a pesquisa.

- Quem: pessoas com deficiência visual convidadas pela ADEVA.

- Critério de seleção solicitado à ADEVA: amostragem intencional, pessoas que se diferenciem em grau de deficiência visual (cegueira e baixa visão) e pessoas com experiências diferentes no uso de smartphones.

- Categorização: pelo grau de deficiência visual (cegueira ou baixa visão) e pela experiência de uso de smartphones com fones de ouvido durante trajetos em locais públicos.

- Quantidade: definida pela ADEVA, com base no aceite dos convites, totalizando quatro voluntários.

- Quando: outubro e novembro de 2015.

- Como: convidados por meio de telefonema e e-mail.

- Para que: para realizar uma análise preliminar das construções verbais obtidas por meio das entrevistas durante o uso de audionavegação, utilizando um ambiente controlado, no objetivo de refinar os conteúdos verbais para a experiência em locais públicos.

- Ferramentas: câmeras de vídeo, equipamento para audionavegação, local privado a céu aberto cedido pela ADEVA. 



\section{APÊNDICE D: PROTOCOLO DO EXPERIMENTO PRÁTICO EM LOCAIS PÚBLICOS}

- Locais:

○ 1 - Estação Vergueiro do Metrô de São Paulo.

- Por quê? Por ser uma estação com arquitetura relativamente complexa (três pavimentos acessados por dois conjuntos de escadas rolantes e fixas) e por constituir-se de caminho usual para pessoas com deficiência visual.

○ 2 - Calçamento a céu aberto entre o acesso oeste da Estação Vergueiro e o Centro Cultural São Paulo.

- Por quê? Por constituir uma conexão em local público entre a Estação Vergueiro e o Centro Cultural São Paulo, distantes cerca de 120 metros.

○ 3 - Centro Cultural São Paulo.

- Por quê? Por abrigar a biblioteca Louis Braille, tornando-se destino constante de pessoas com deficiência visual.

- Quem: pessoas com deficiência visual convidadas pelo Metrô de São Paulo.

- Critério de seleção: amostragem intencional, os voluntários foram selecionados por meio da análise das características dos usuários com deficiência visual cadastrados pelo Metrô de São Paulo, com diferentes peculiaridades sensoriais, cognitivas e de autonomia, dentro da esfera da deficiência visual.

○ Categorização: grau de deficiência visual (cegueira ou baixa visão); presença de memória visual (deficiência visual congênita ou adquirida); experiência de uso de smartphones com fones de ouvido durante trajetos em locais públicos; capacidade de autonomia em orientação e mobilidade durante trajetos em espaços públicos; uso de diferentes tipos de ferramentas de auxílio à acessibilidade; familiaridade com os locais utilizados na experiência.

- Quantidade: definida pelo critério de saturação dos dados, totalizando sete voluntários observados.

- Quando: entre julho e setembro de 2016.

- Como: convidados por meio de telefonema e e-mail. 
- Para que: para conhecer as peculiaridades da utilização de audionavegação em ambientes públicos por pessoas com deficiência visual, em aspectos como usabilidade, interferências que podem causar ao usuário com relação a outros recursos de acessibilidade para uso público, interferências que os elementos presentes nos ambientes públicos podem causar na compreensão da audionavegação.

- Ferramentas: câmeras de vídeo, equipamento para audionavegação, estação do Metrô, calçadas públicas e ambiente do Centro Cultural São Paulo. 


\section{APÊNDICE E: CONSTRUÇõES VERBAIS PARA CADA LOCAL PÚBLICO}

Figura 33 - Plataforma, porta de saída do trem (verbalização: “Direita”)

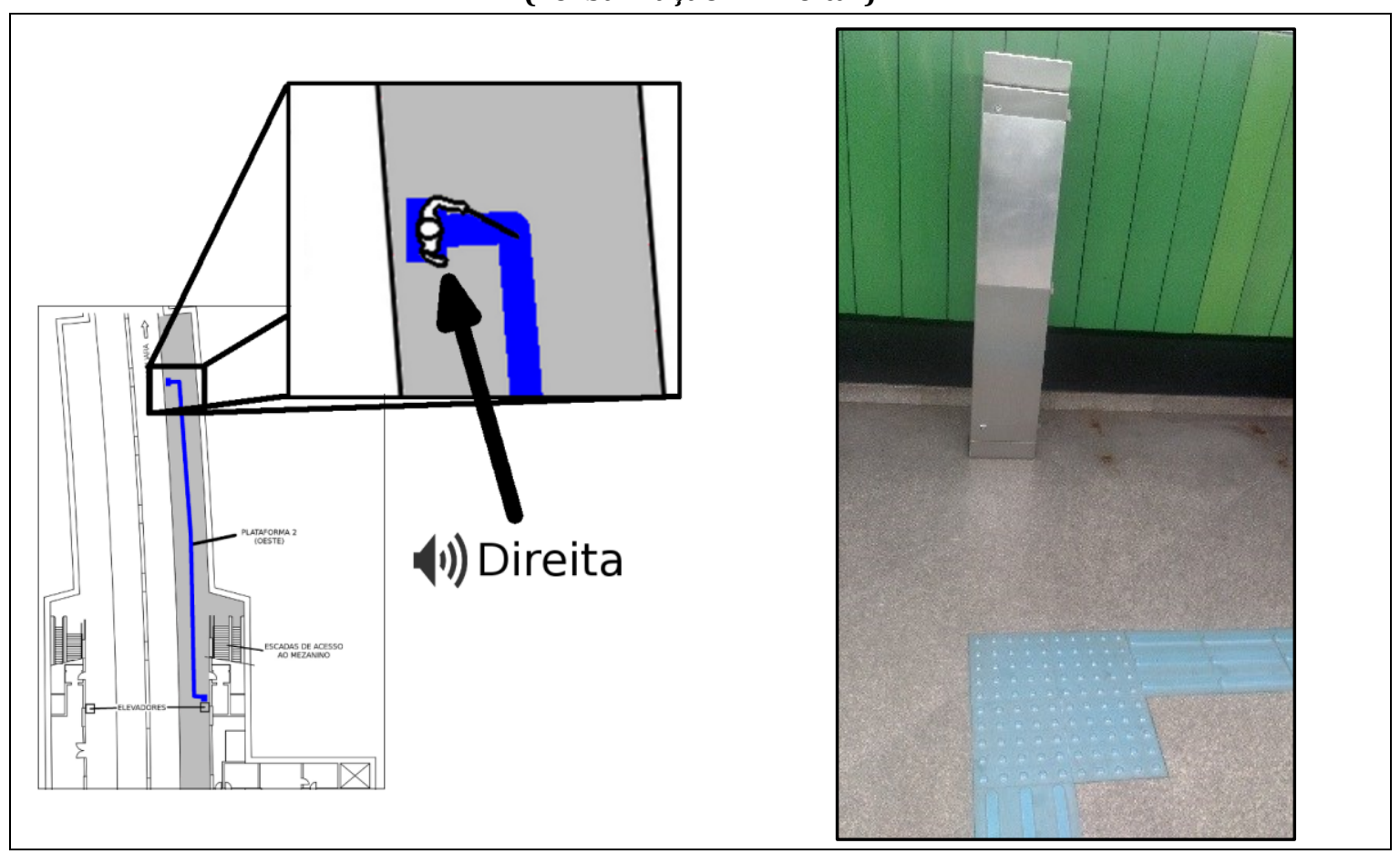

Fonte: do autor (2016)

Figura 34 - Plataforma, sentido norte

(verbalização: “Siga o piso tátil”)

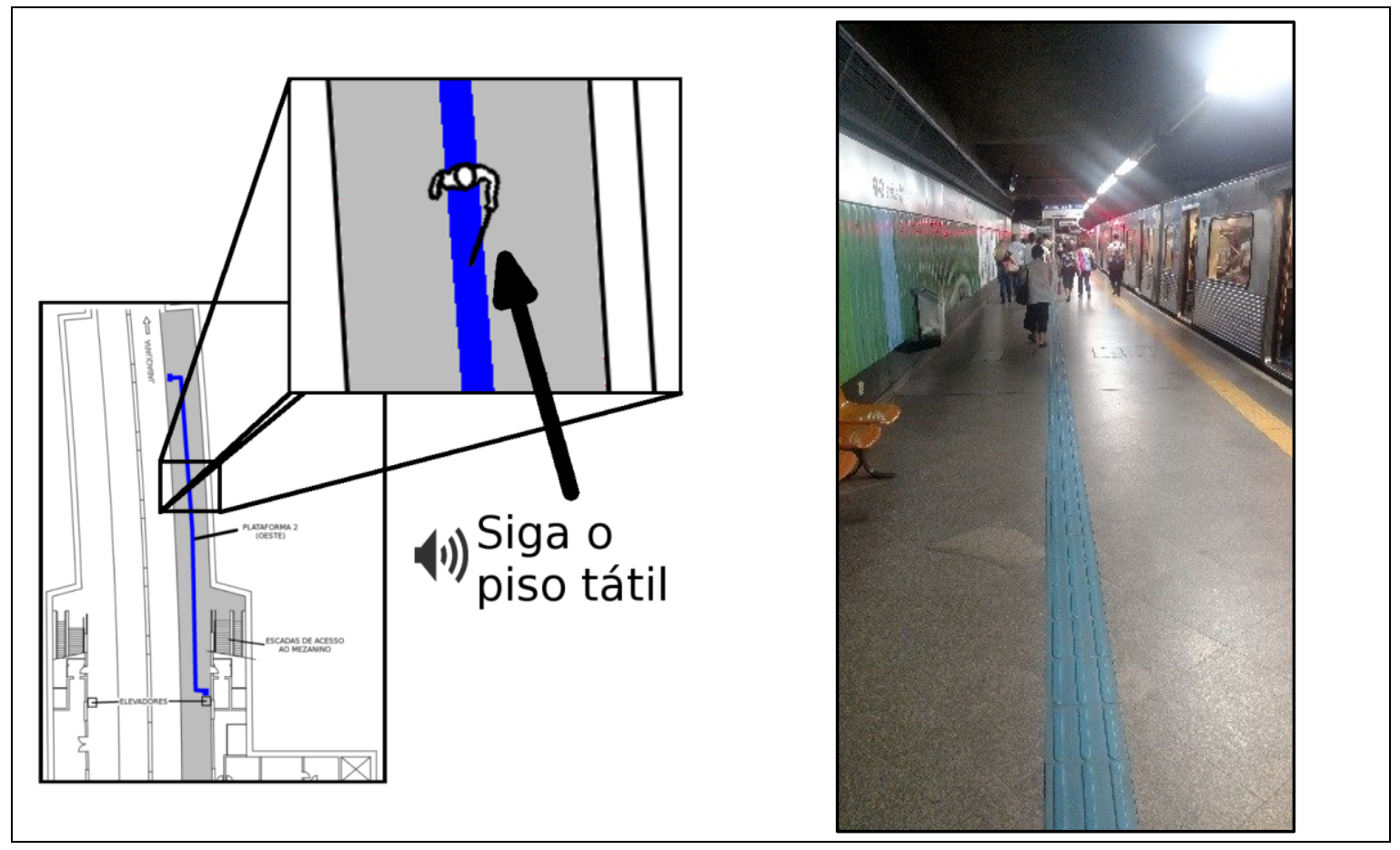

Fonte: do autor (2016) 
Figura 35 - Plataforma, porta de saída do trem (verbalização: “Esquerda, escadas. Frente, elevador”)

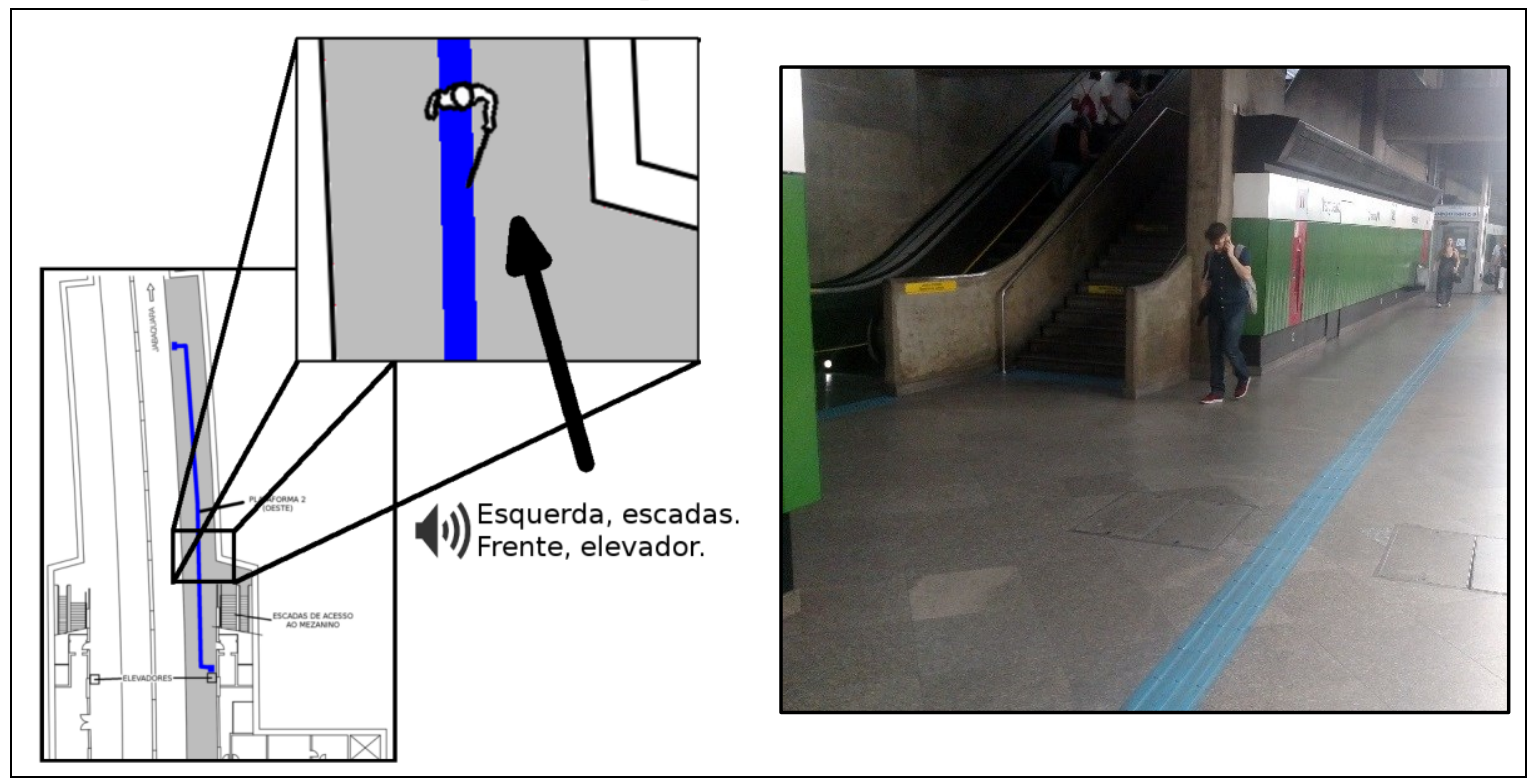

Fonte: do autor (2016)

Figura 36 - Plataforma, sentido escadas de acesso ao mezanino (verbalização: "Escadas à direita. Primeira, rolante. Segunda, fixa”)

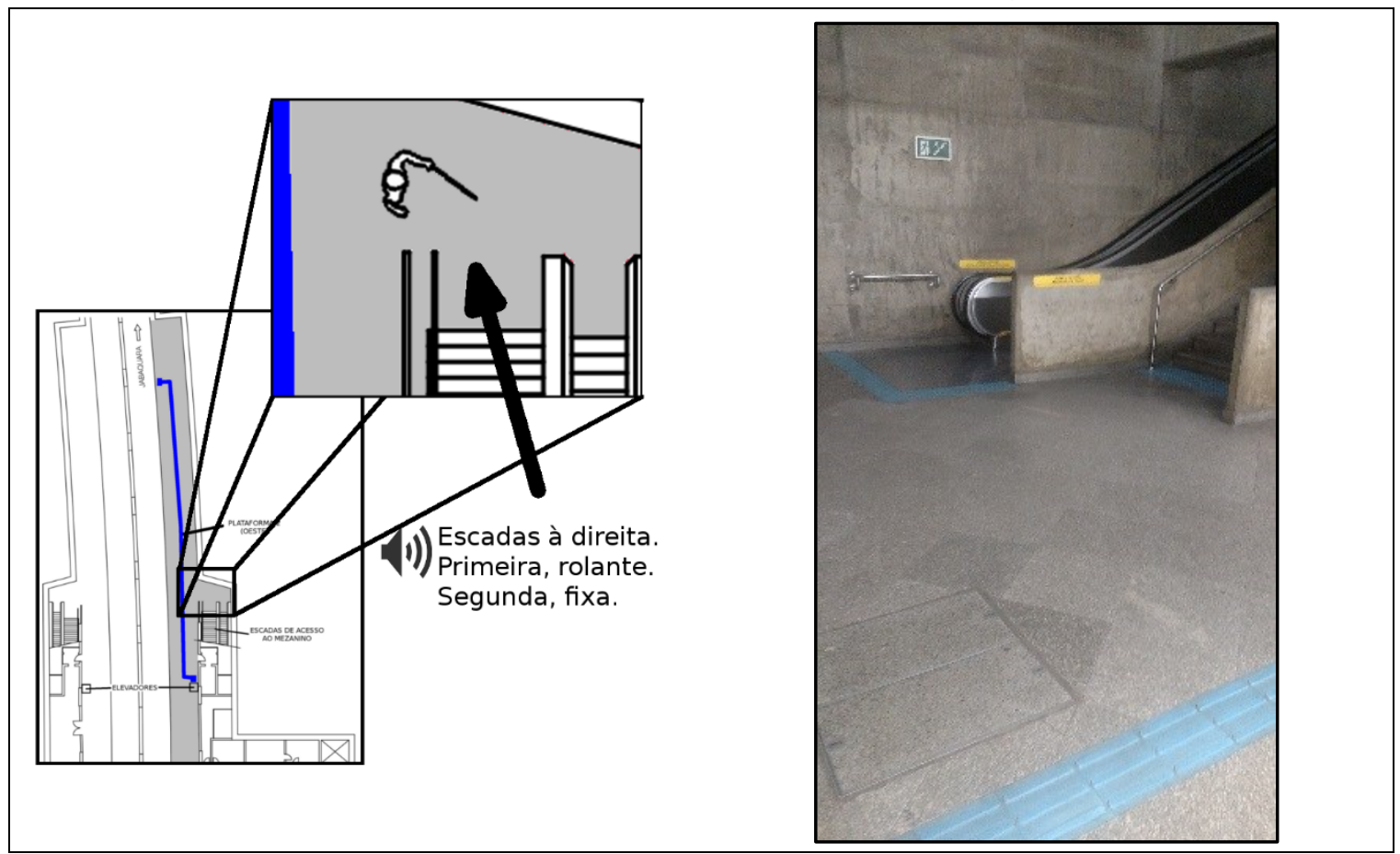

Fonte: do autor (2016) 
Figura 37 - Plataforma, sentido elevador

(verbalização: "Siga o piso tátil")

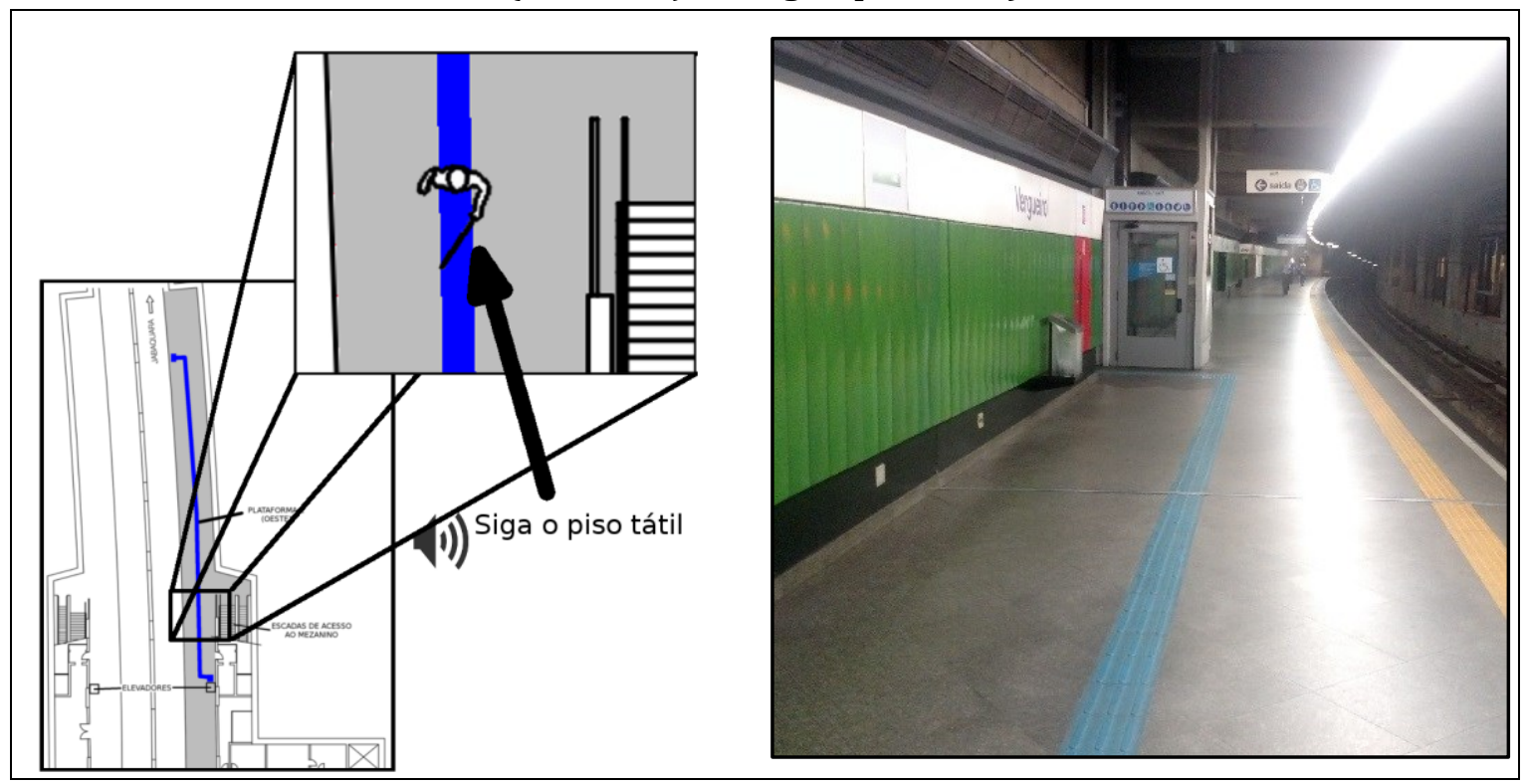

Fonte: do autor (2016)

Figura 38 - Plataforma, chegada no elevador

(verbalização: “Elevador")

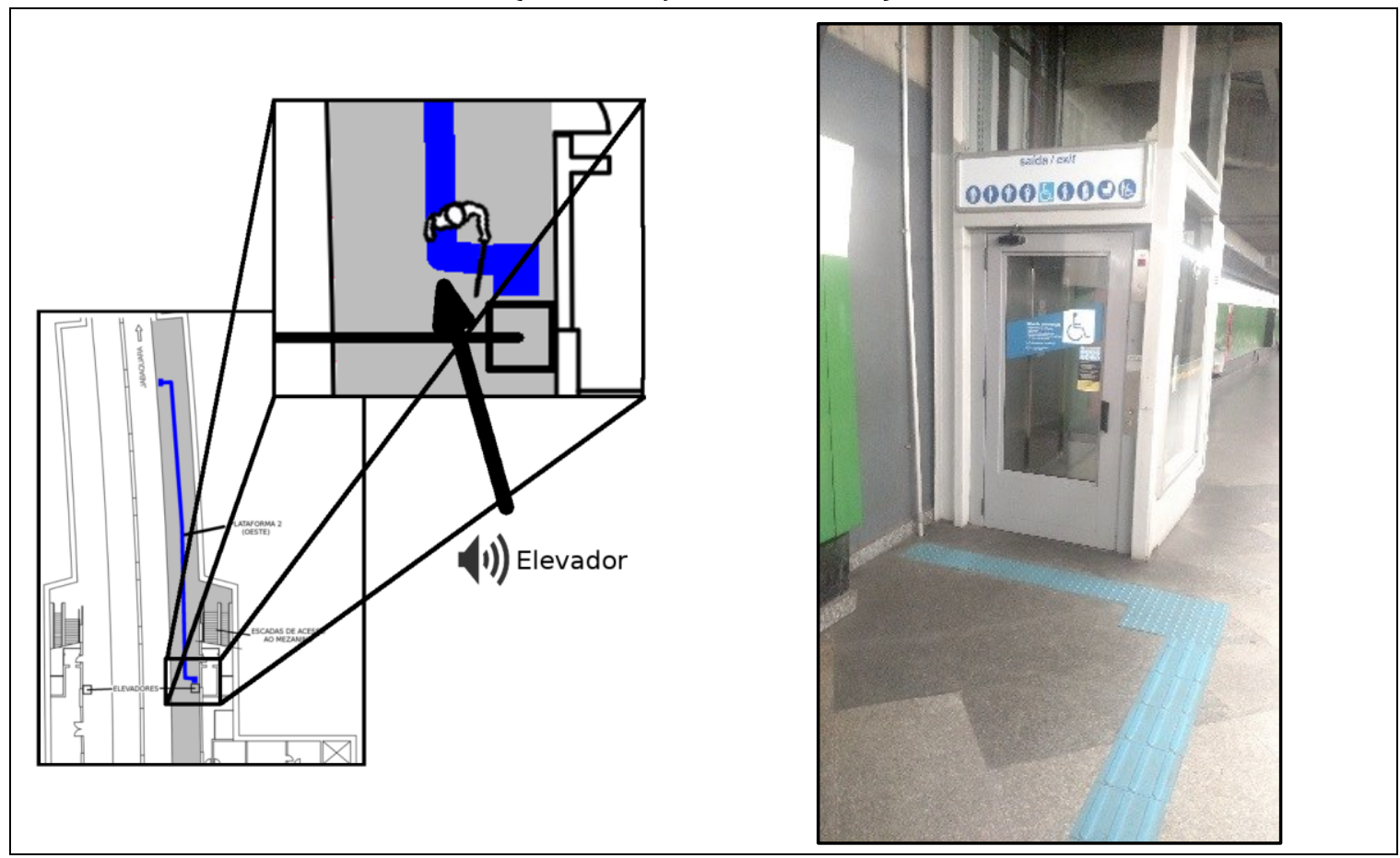

Fonte: do autor (2016) 
Figura 39 - Mezanino área paga (dentro dos bloqueios), saída das escadas da plataforma (verbalização: "Siga a parede à direita”)

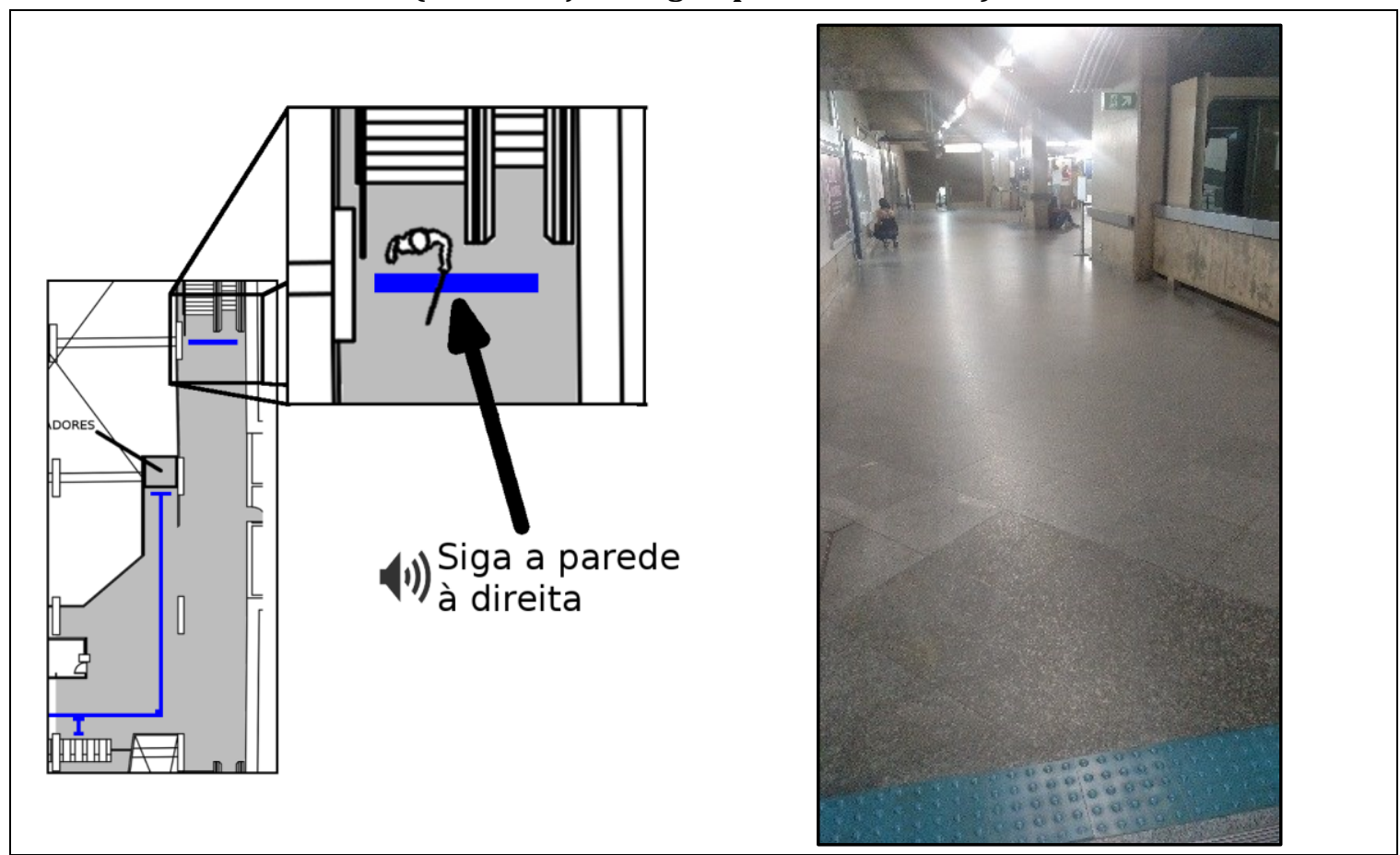

Fonte: do autor (2016)

Figura 40 - Mezanino área paga, chegando no piso tátil, à direita, para a saída (verbalização: "Siga o piso tátil")

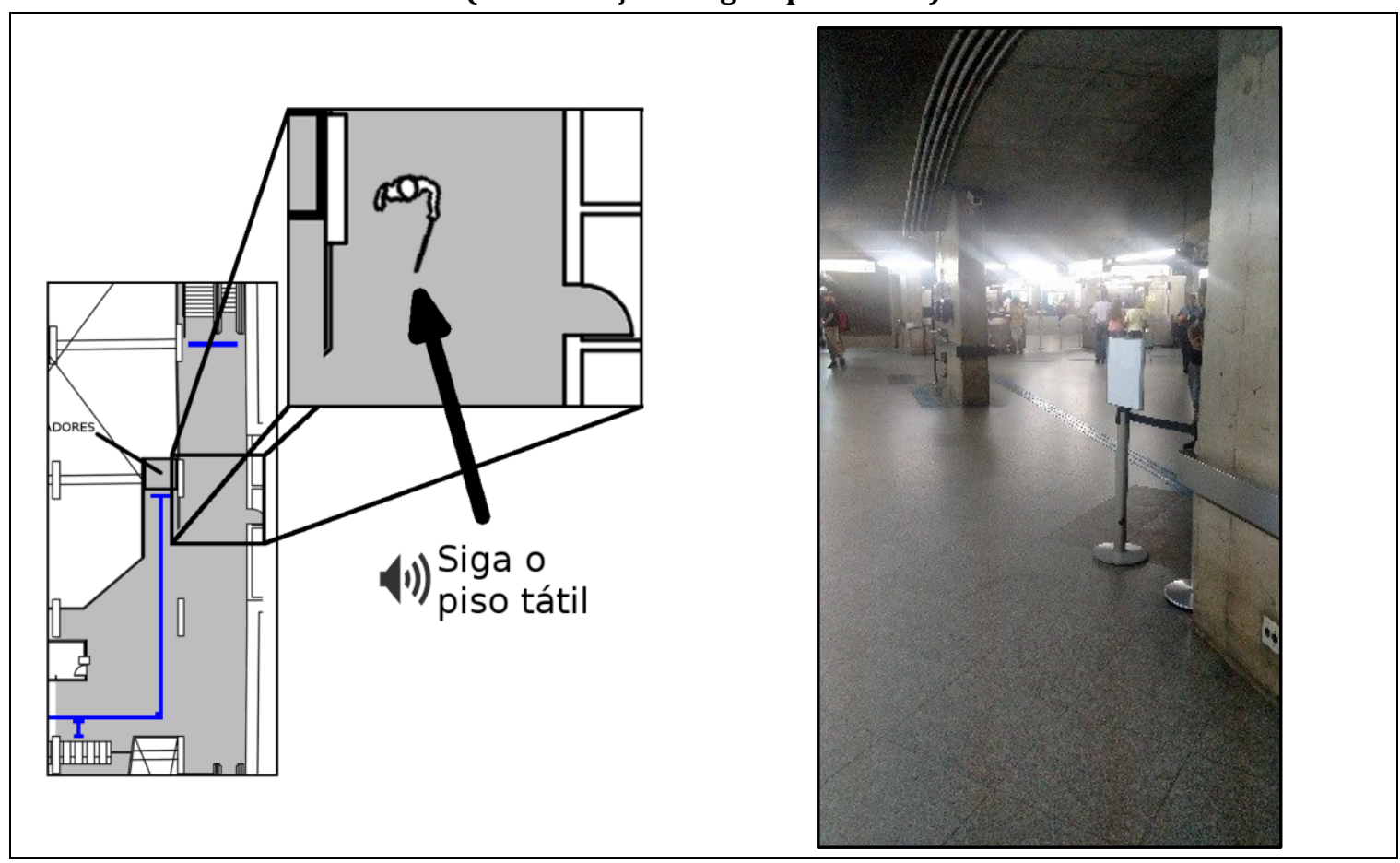

Fonte: do autor (2016) 
Figura 41 - Mezanino área paga, saída do elevador (verbalização: "Siga o piso tátil")

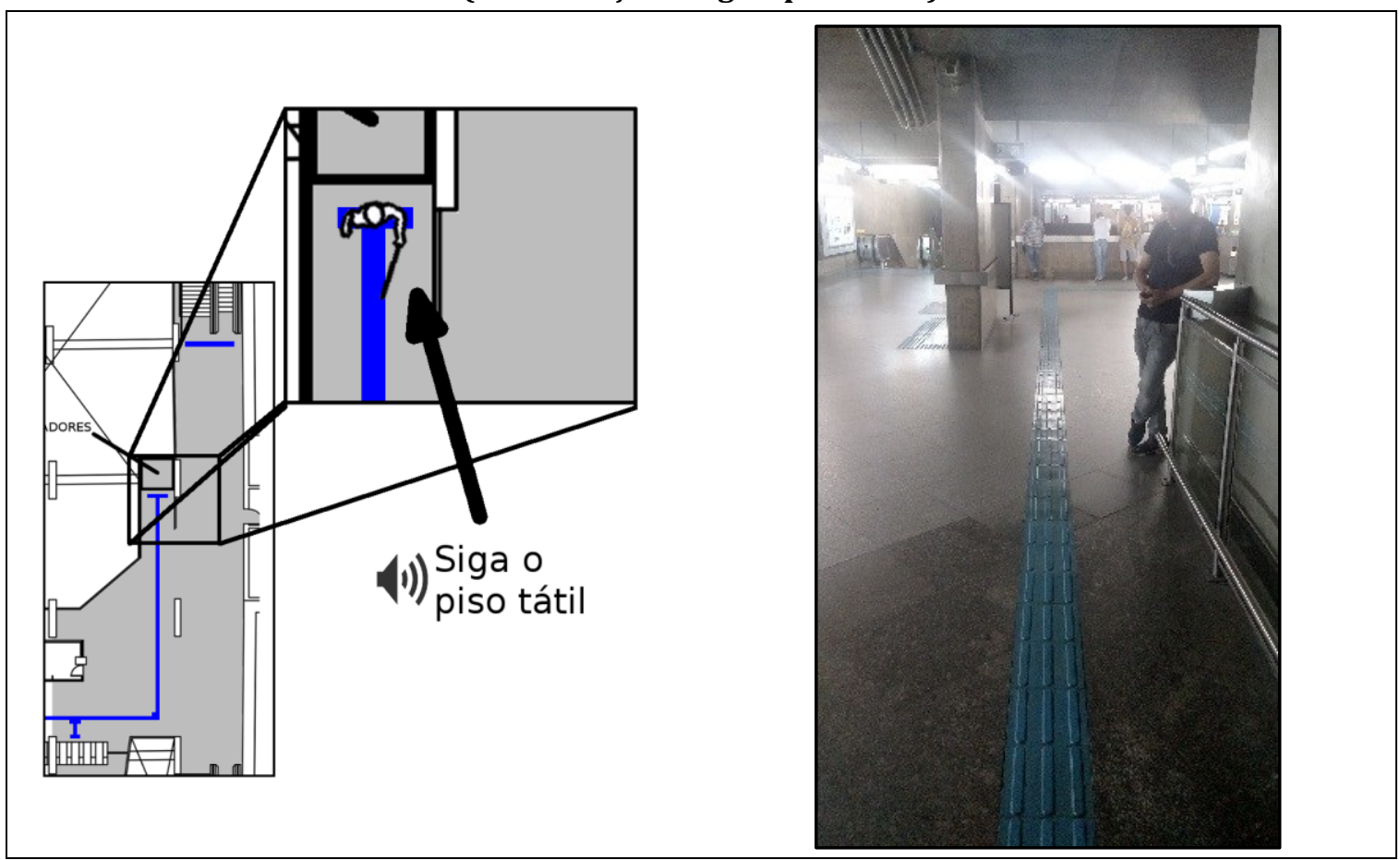

Fonte: do autor (2016)

Figura 42 - Mezanino área paga, curva à direita no piso tátil para a saída (verbalização: “Direita”)

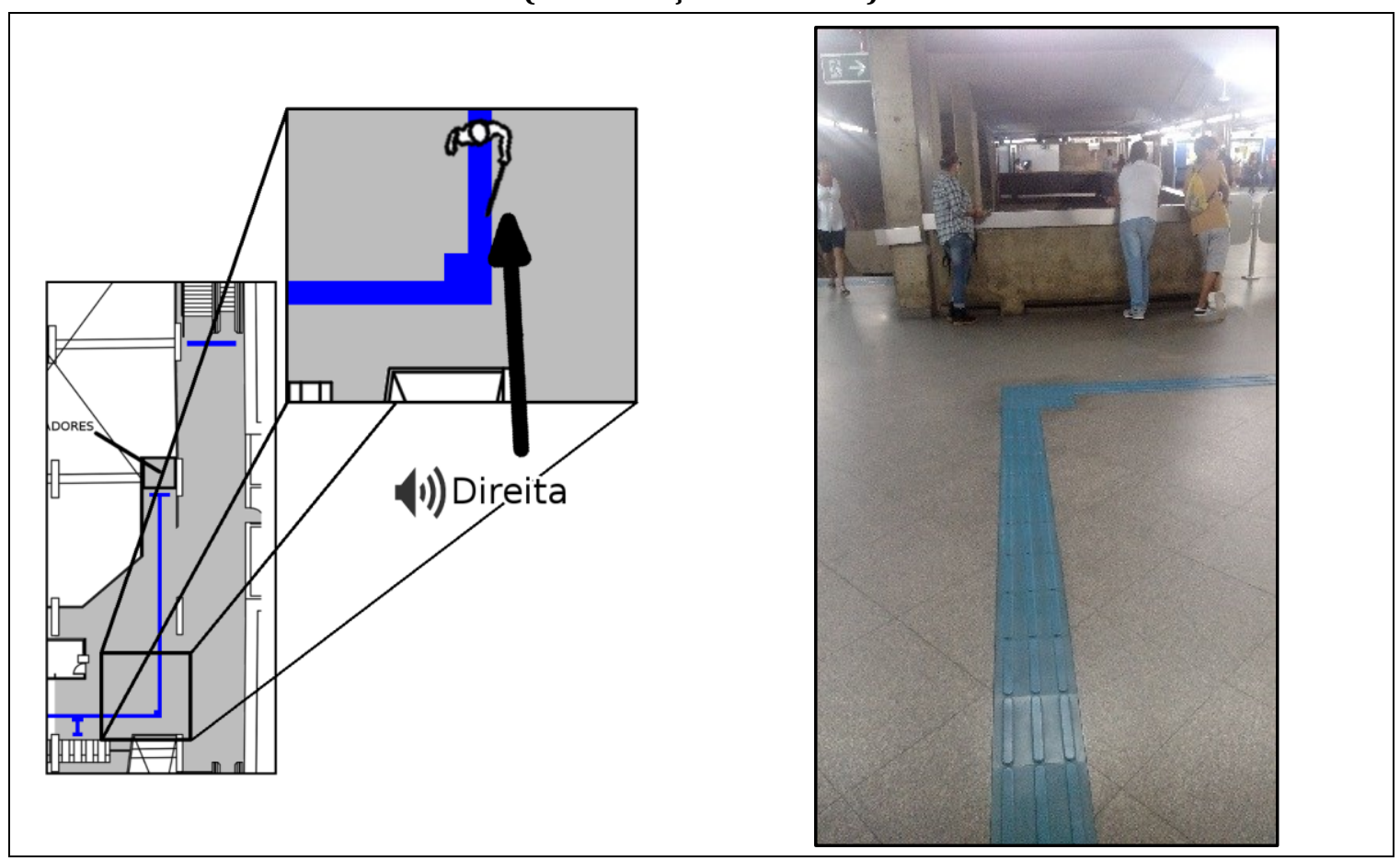

Fonte: do autor (2016) 
Figura 43 - Mezanino área paga, curva à esquerda para a saída (verbalização: “Saída à esquerda”)

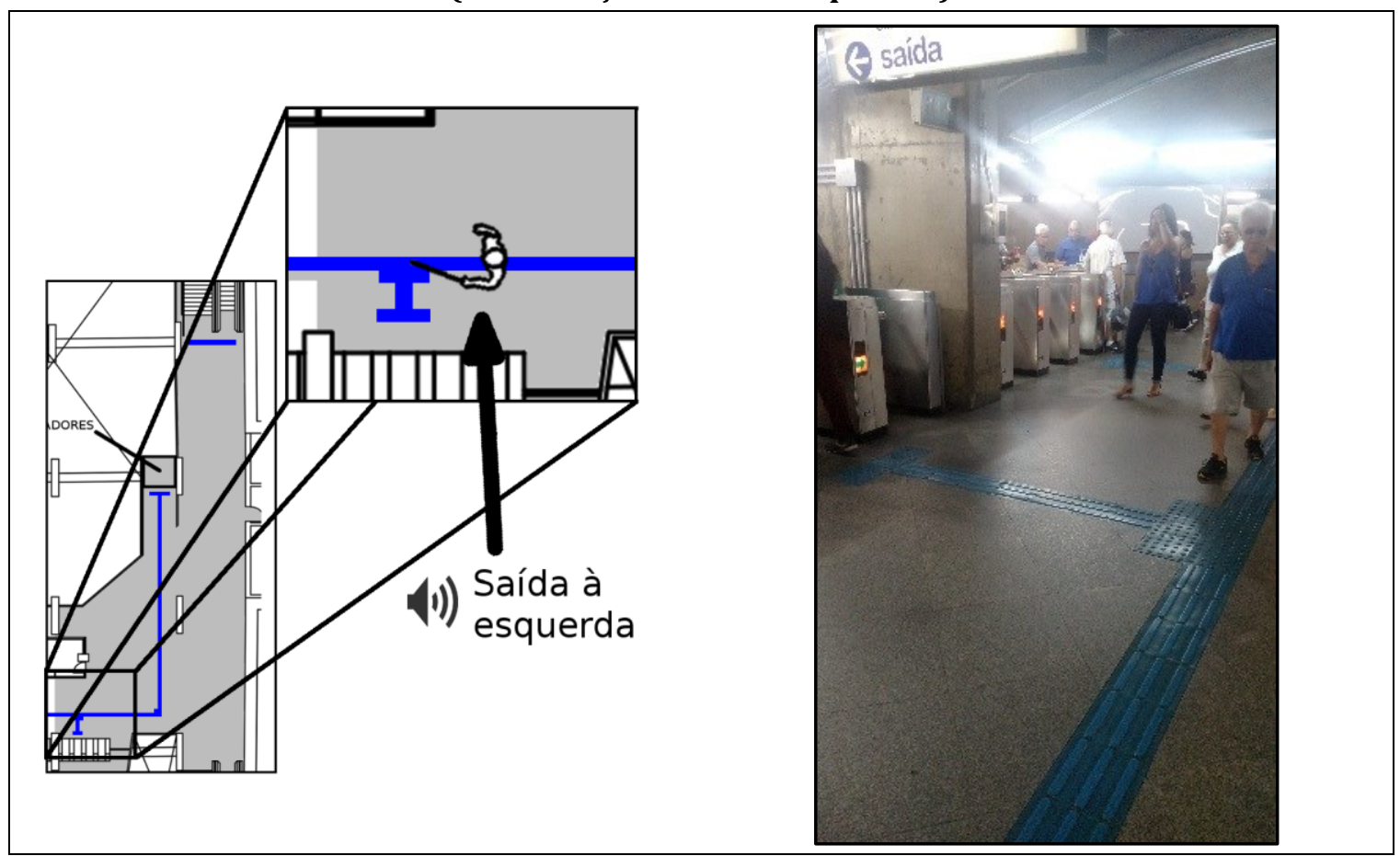

Fonte: do autor (2016)

Figura 44 - Mezanino área livre, após os bloqueios (verbalização: “Siga o piso tátil”)

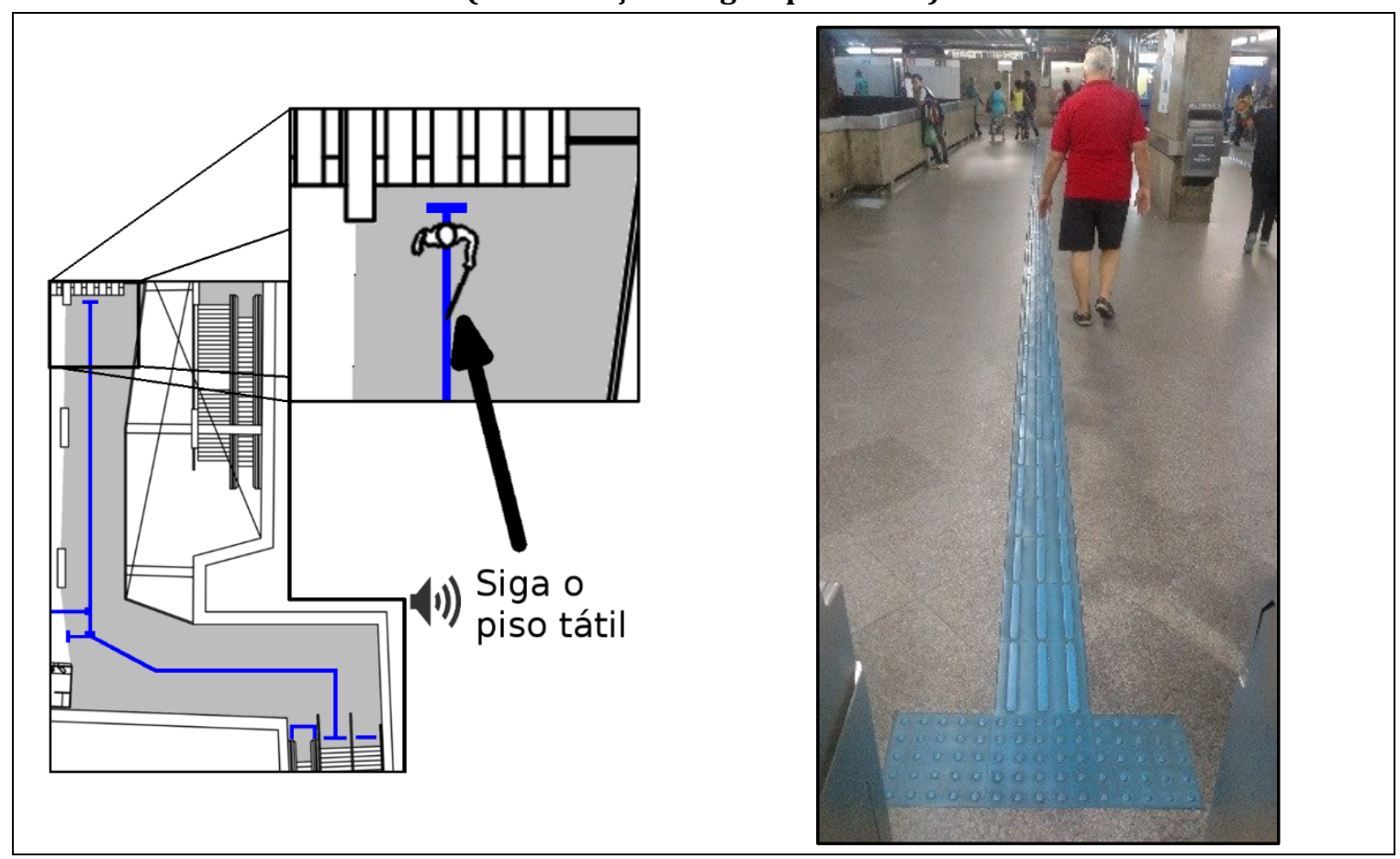

Fonte: do autor (2016) 
Figura 45 - Mezanino área livre, bifurcação para os acessos oeste e leste (verbalização: “Esquerda, centro cultural São Paulo. Direita, colégio Santo Agostinho”)

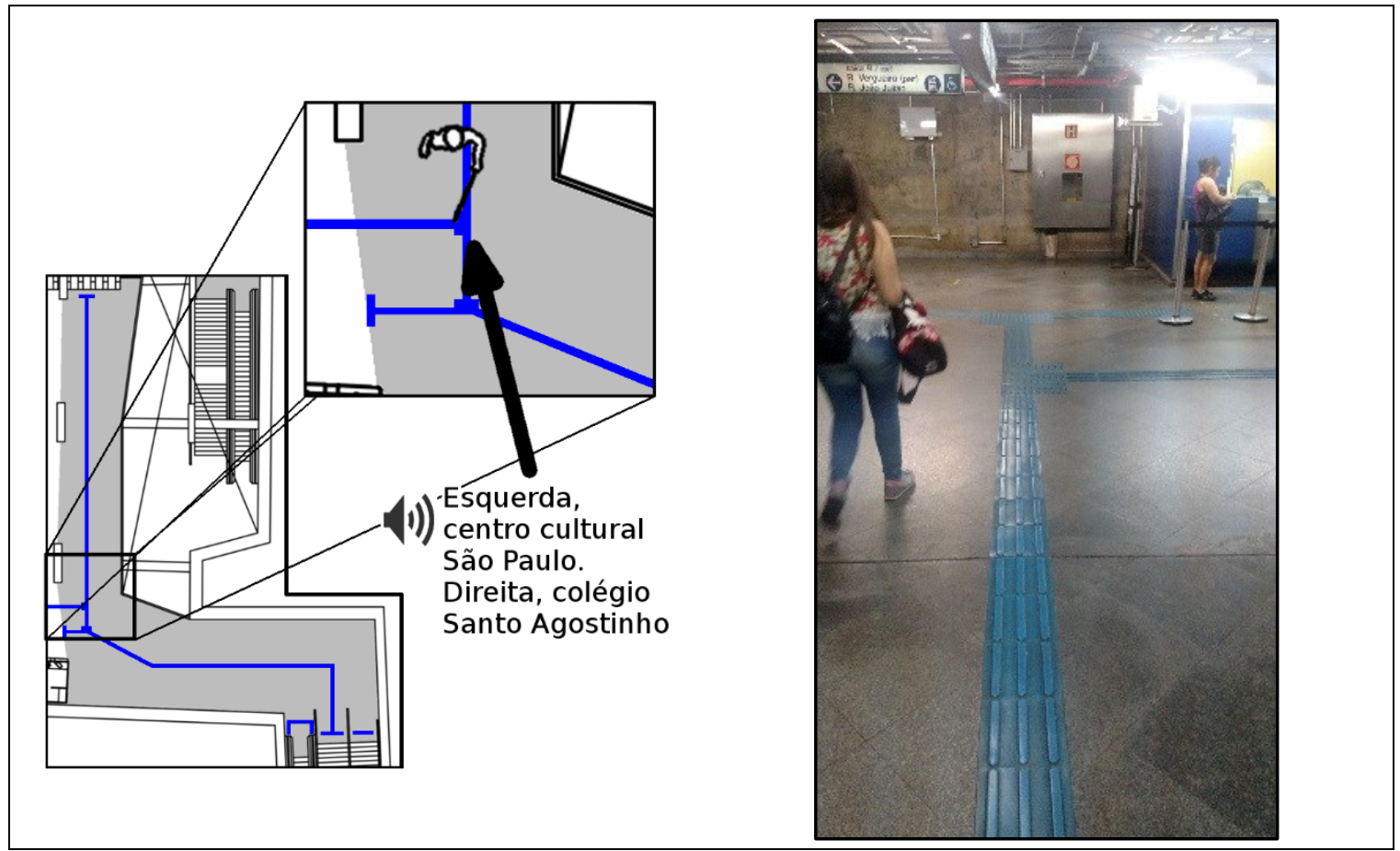

Fonte: do autor (2016)

Figura 46 - Mezanino área livre, sentido acesso oeste (verbalização: "Siga o piso tátil”)

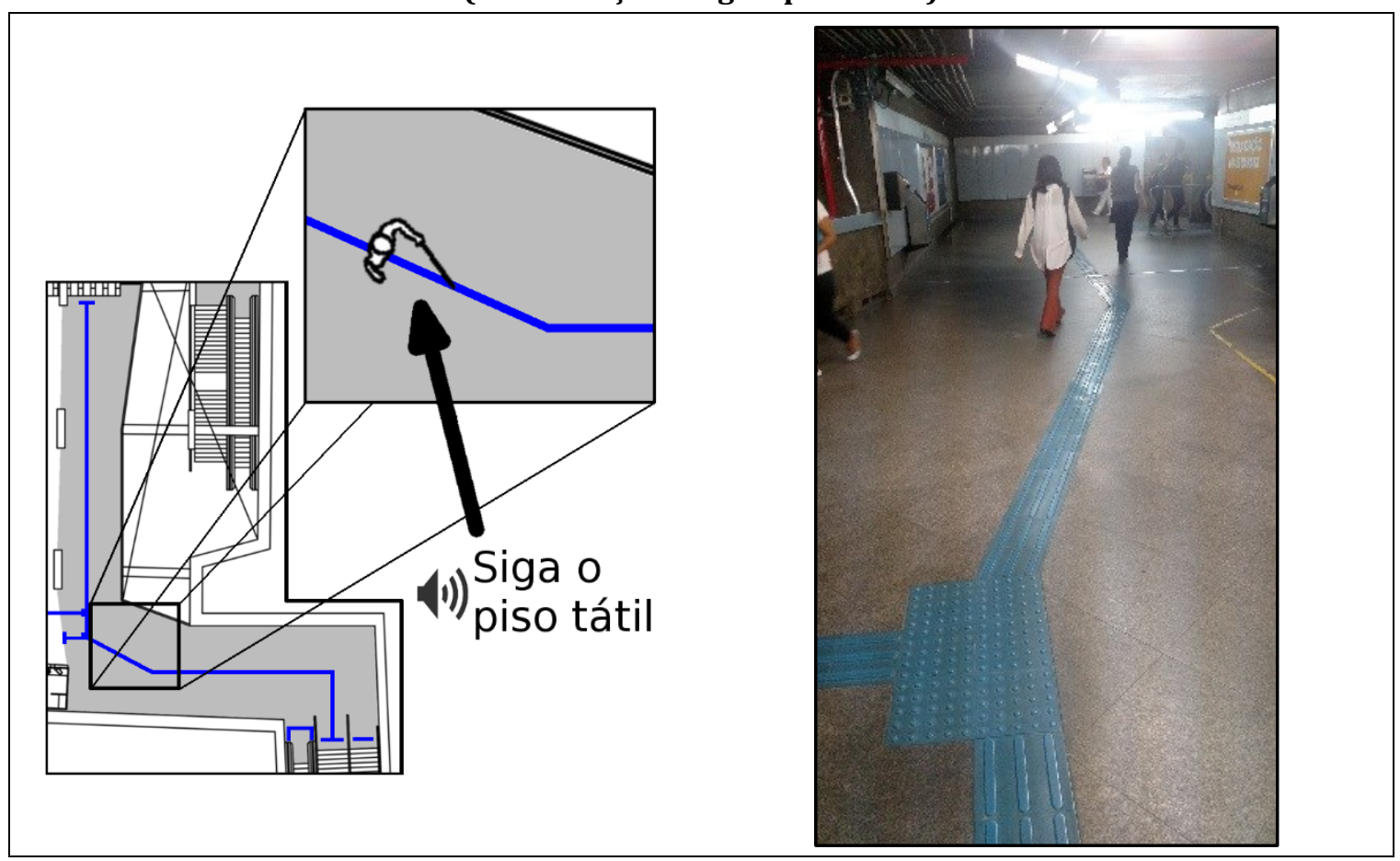

Fonte: do autor (2016) 
Figura 47 - Mezanino área livre, escadas para o acesso oeste (verbalização: “Escadas à direita. Primeira e segunda, fixa. Terceira, rolante”)

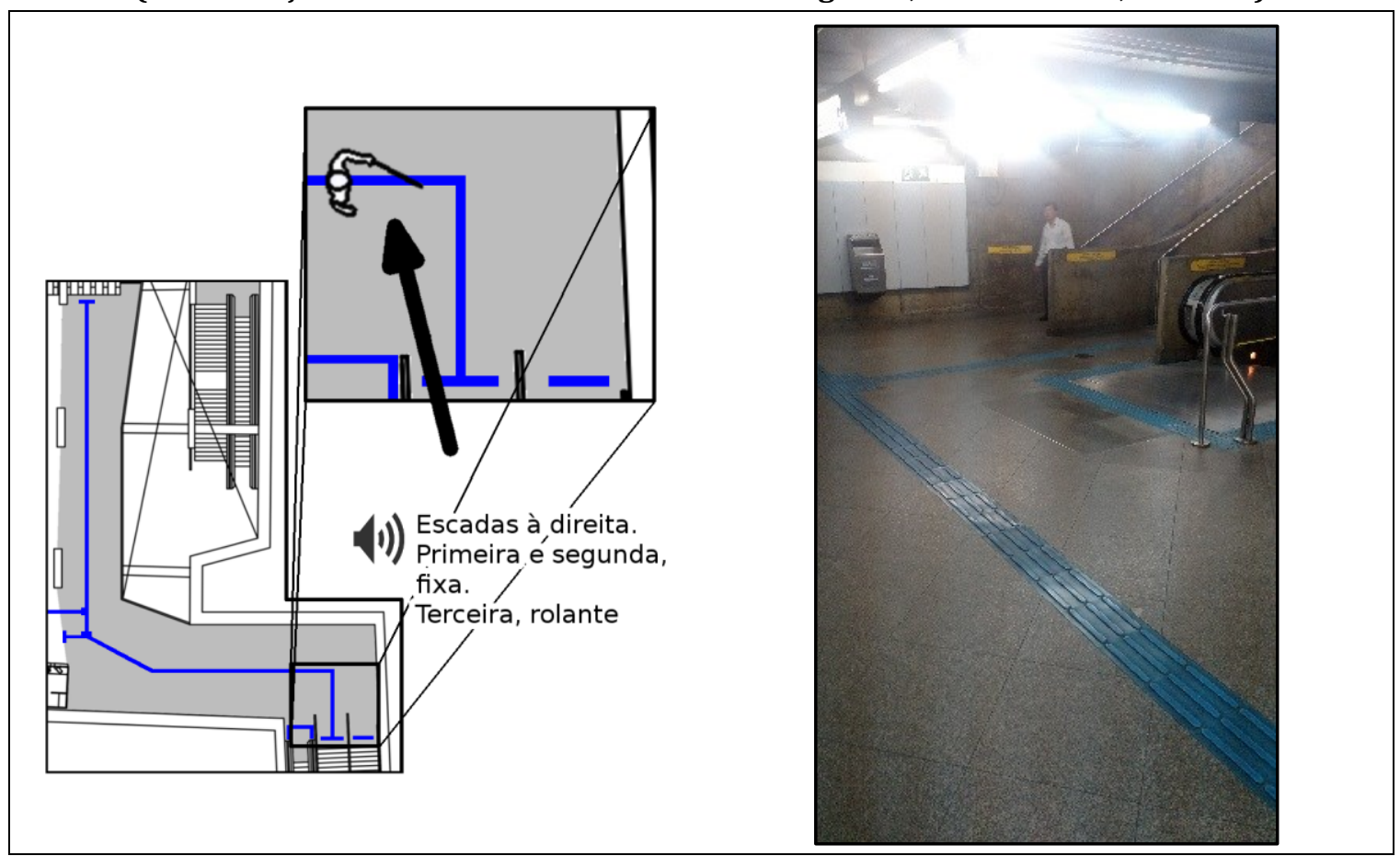

Fonte: do autor (2016)

Figura 48 - Acesso oeste, saídas das escadas do mezanino (verbalização: “Esquerda: Centro Cultural. Direita: ponto de ônibus e táxi da Rua Vergueiro.")

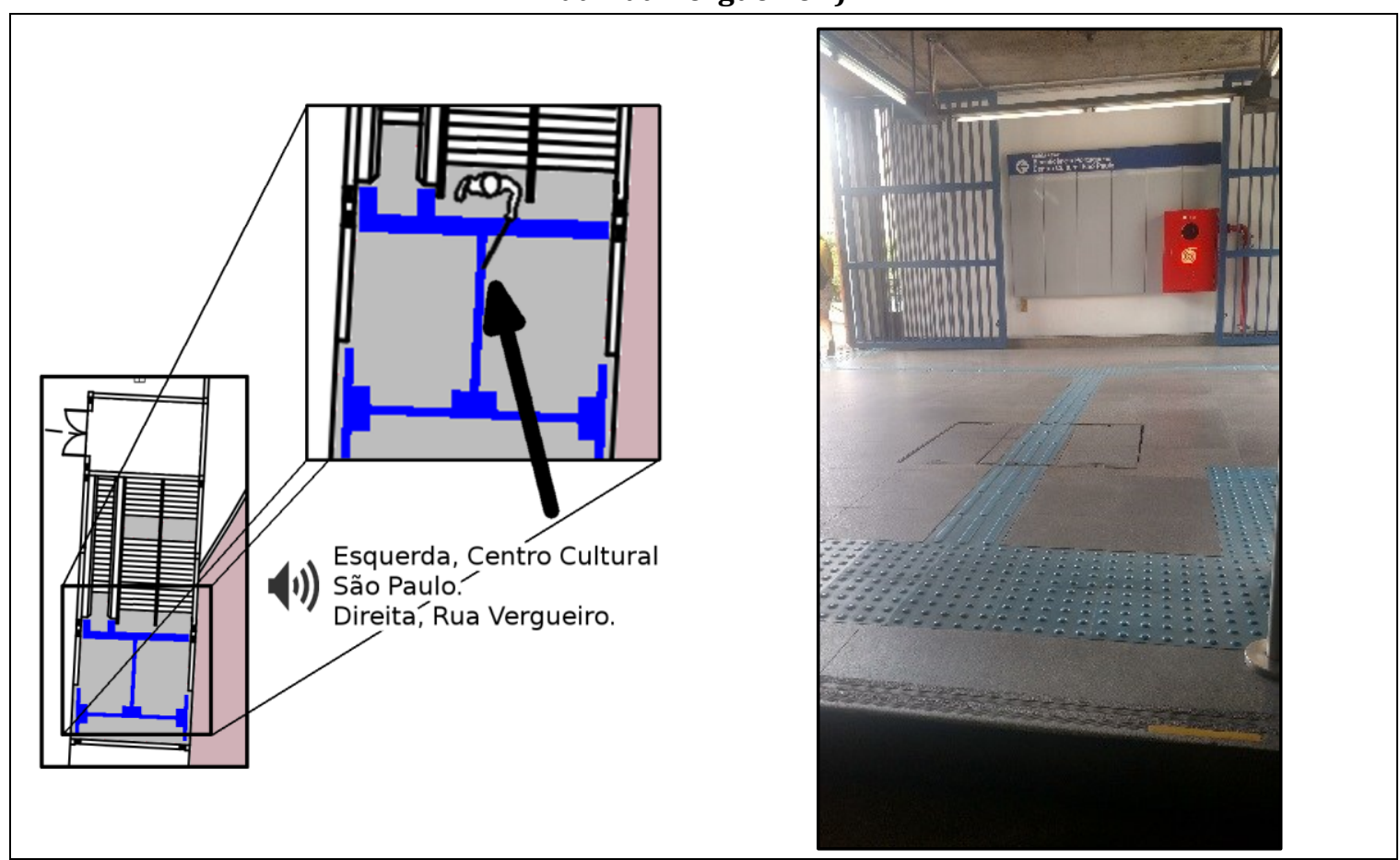

Fonte: do autor (2016) 
Figura 49 - Acesso oeste, saída oeste

(verbalização: “Esquerda, Centro Cultural São Paulo. Direita, viaduto Beneficência”)

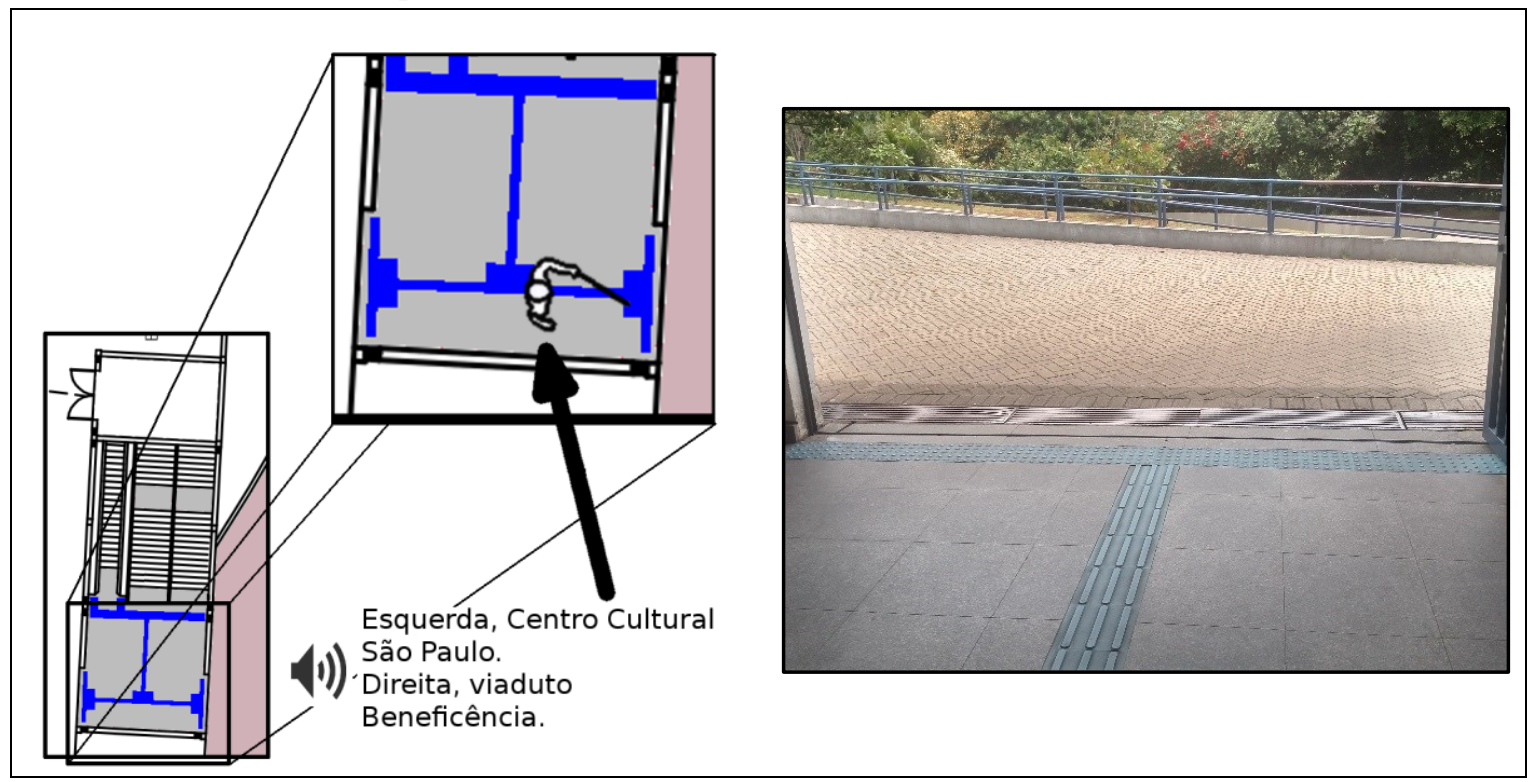

Fonte: do autor (2016)

Figura 50 - Rampa de acesso ao Centro Cultural São Paulo (verbalização: “Você está seguindo no sentido Centrol Cultural São Paulo”)

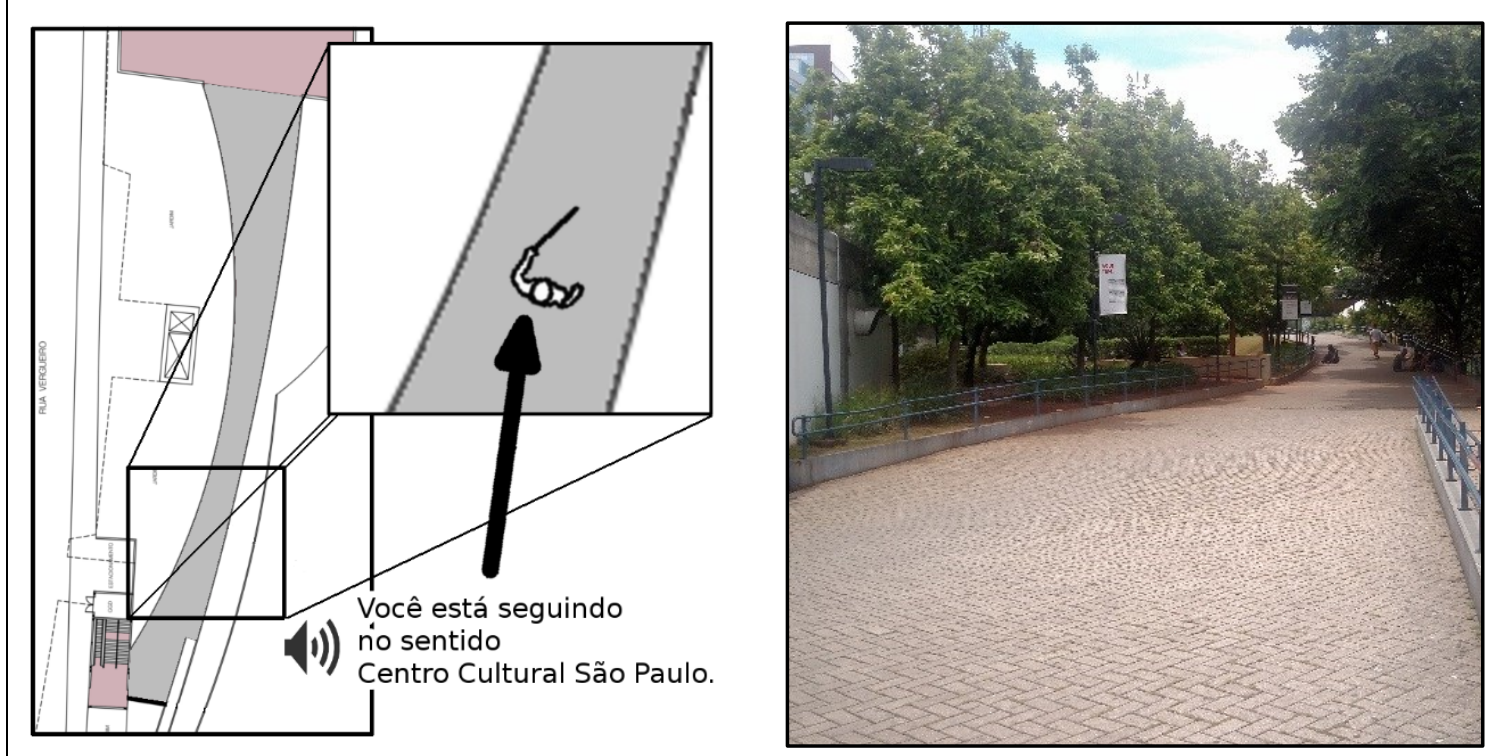

Fonte: do autor (2016) 
Figura 51 - Rampa de acesso ao Centro Cultural São Paulo (ponto 2) (verbalização: "Você está seguindo no sentido Centrol Cultural São Paulo")

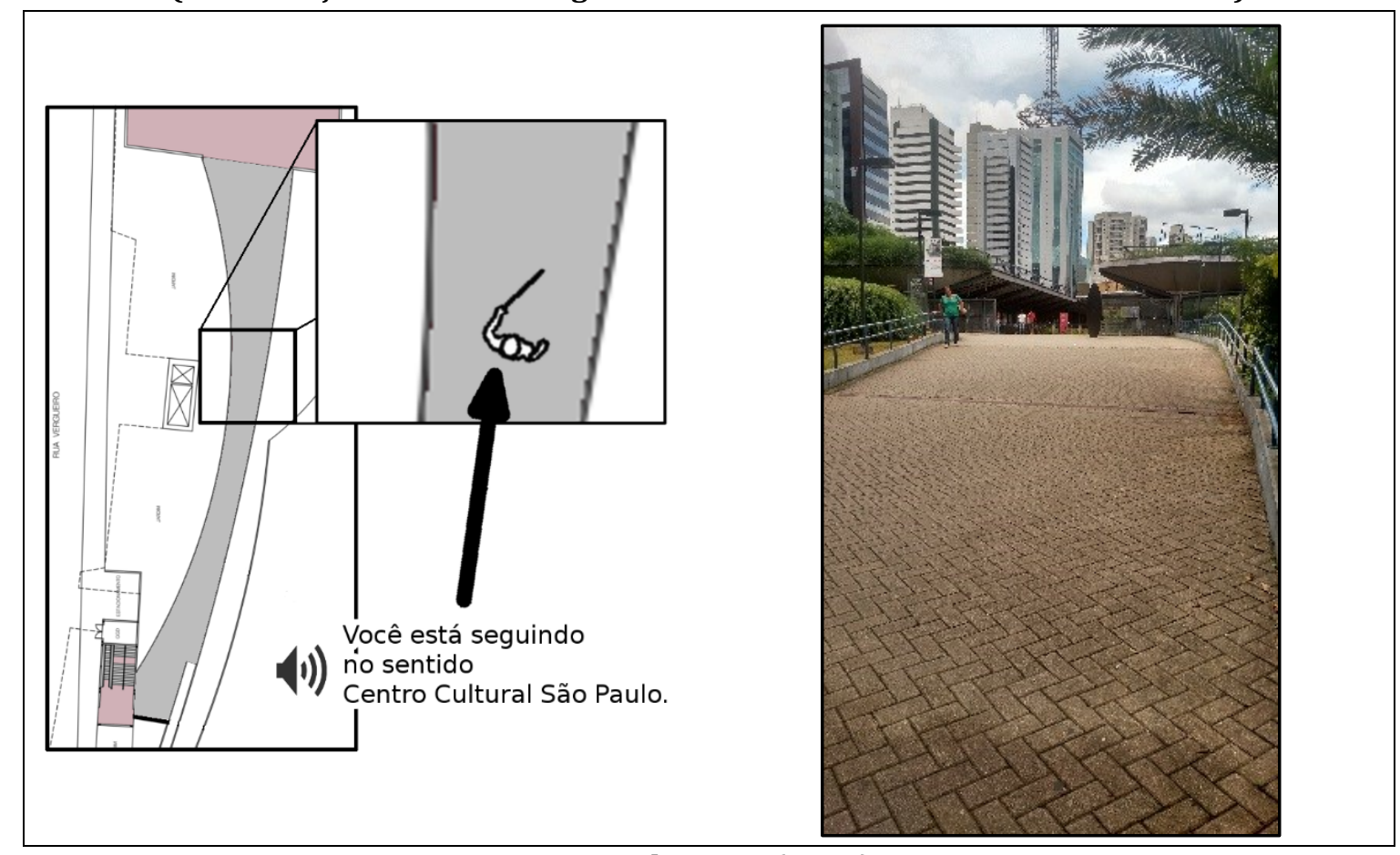

Fonte: do autor (2016)

Figura 52 - Entrada do Centro Cultural São Paulo - porta oeste (verbalização: "Bem-vindo ao Centro Cultural São Paulo")

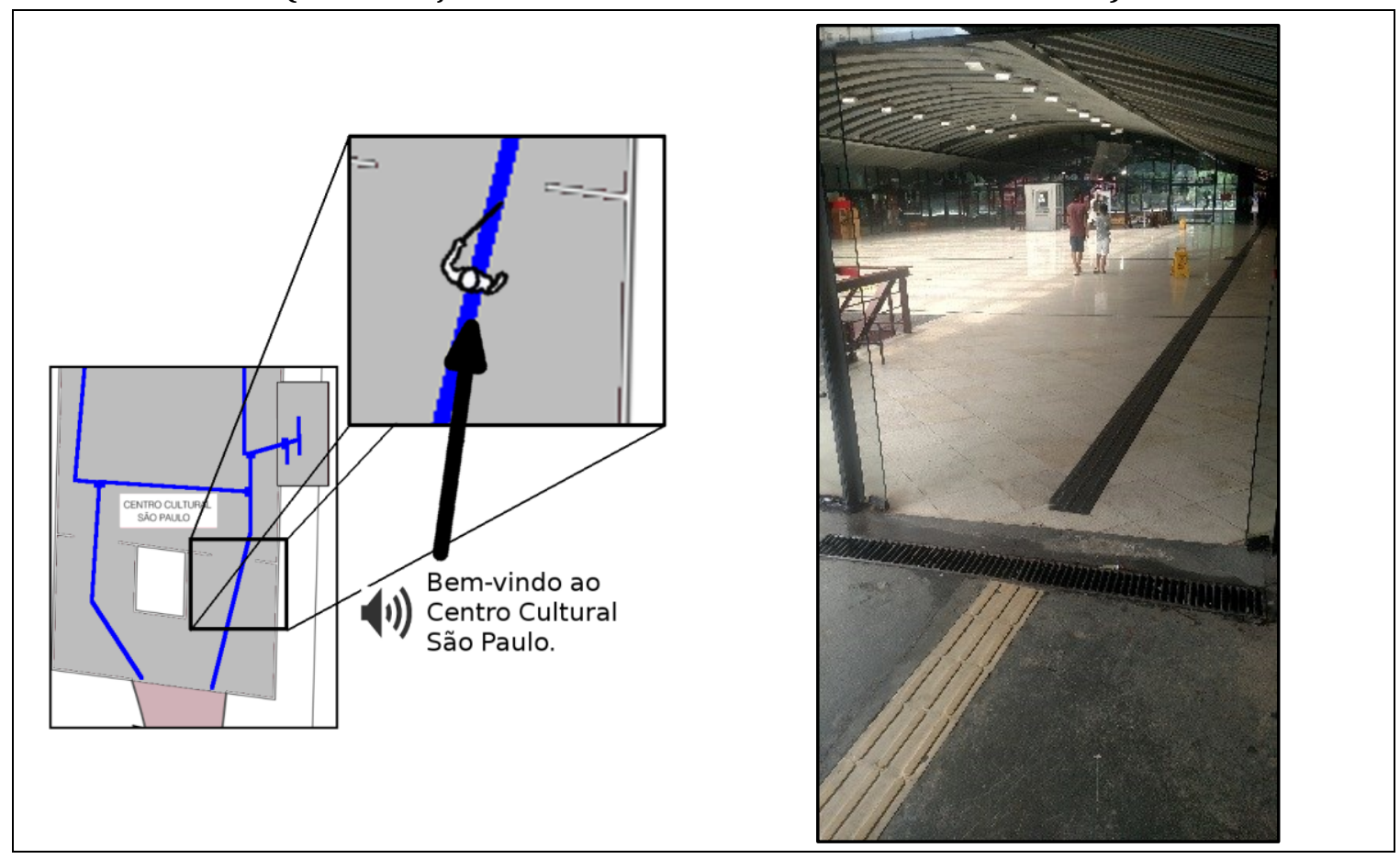

Fonte: do autor (2016) 
Figura 53 - Entrada do Centro Cultural São Paulo - porta leste - os voluntários não usaram (verbalização: “Bem-vindo ao Centro Cultural São Paulo”)

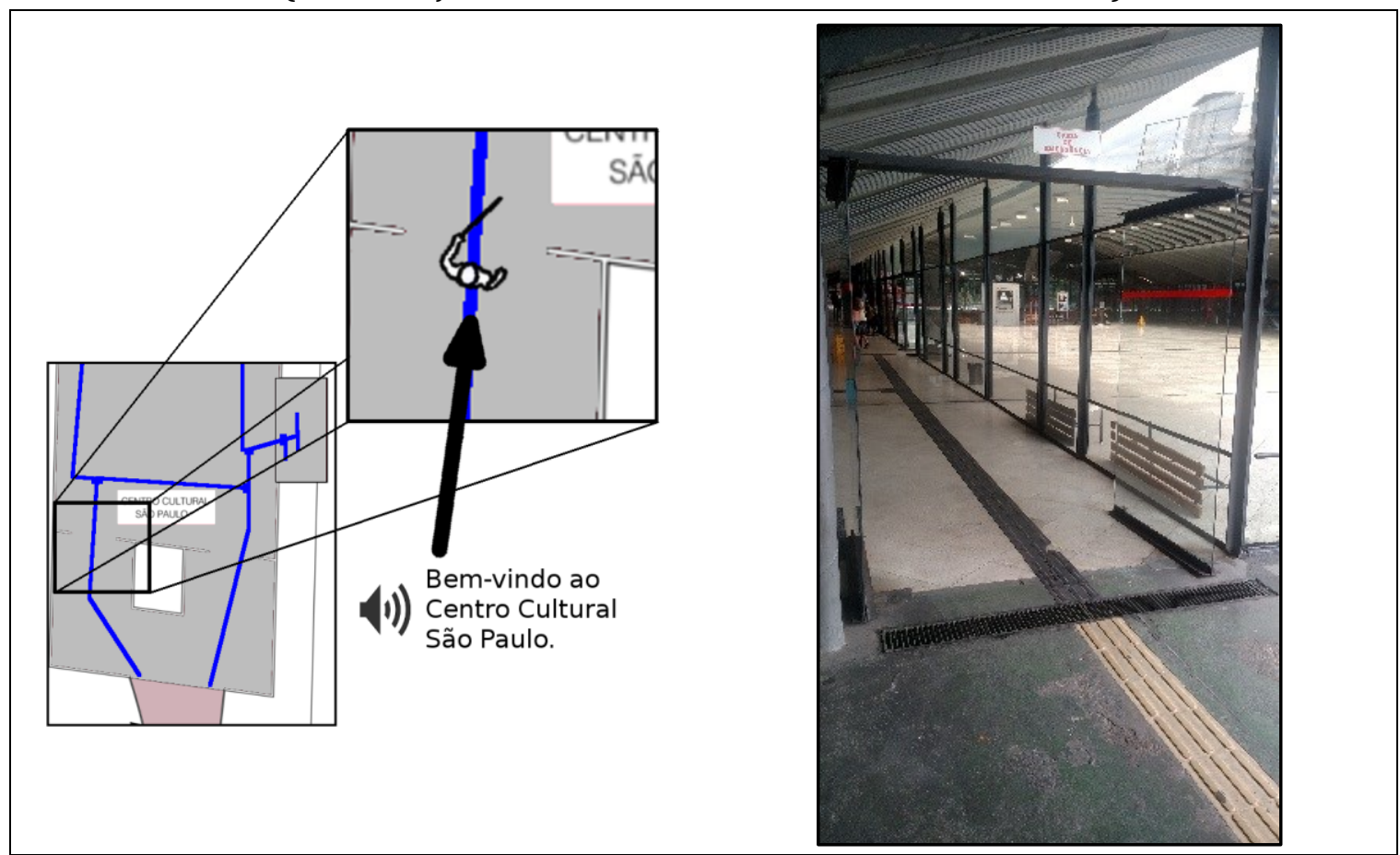

Fonte: do autor (2016)

Figura 54 - Piso tátil oeste para a biblioteca Louis Braille (verbalização: “Esquerda, pista de dança. Frente, biblioteca”)

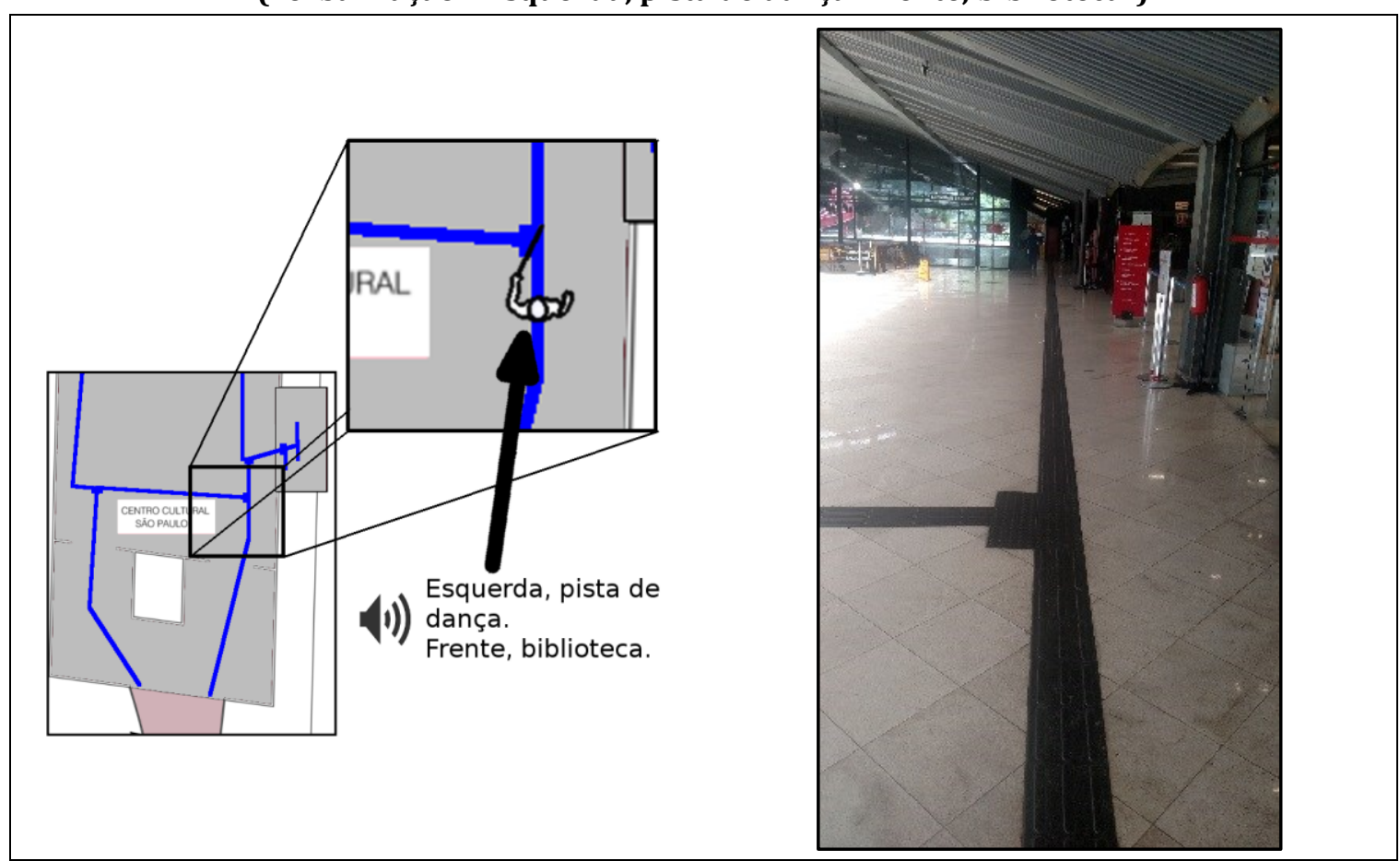

Fonte: do autor (2016) 
Figura 55 - Piso tátil leste para a biblioteca Louis Braille - os voluntários não usaram (verbalização: “Esquerda, saída. Direita, biblioteca”)

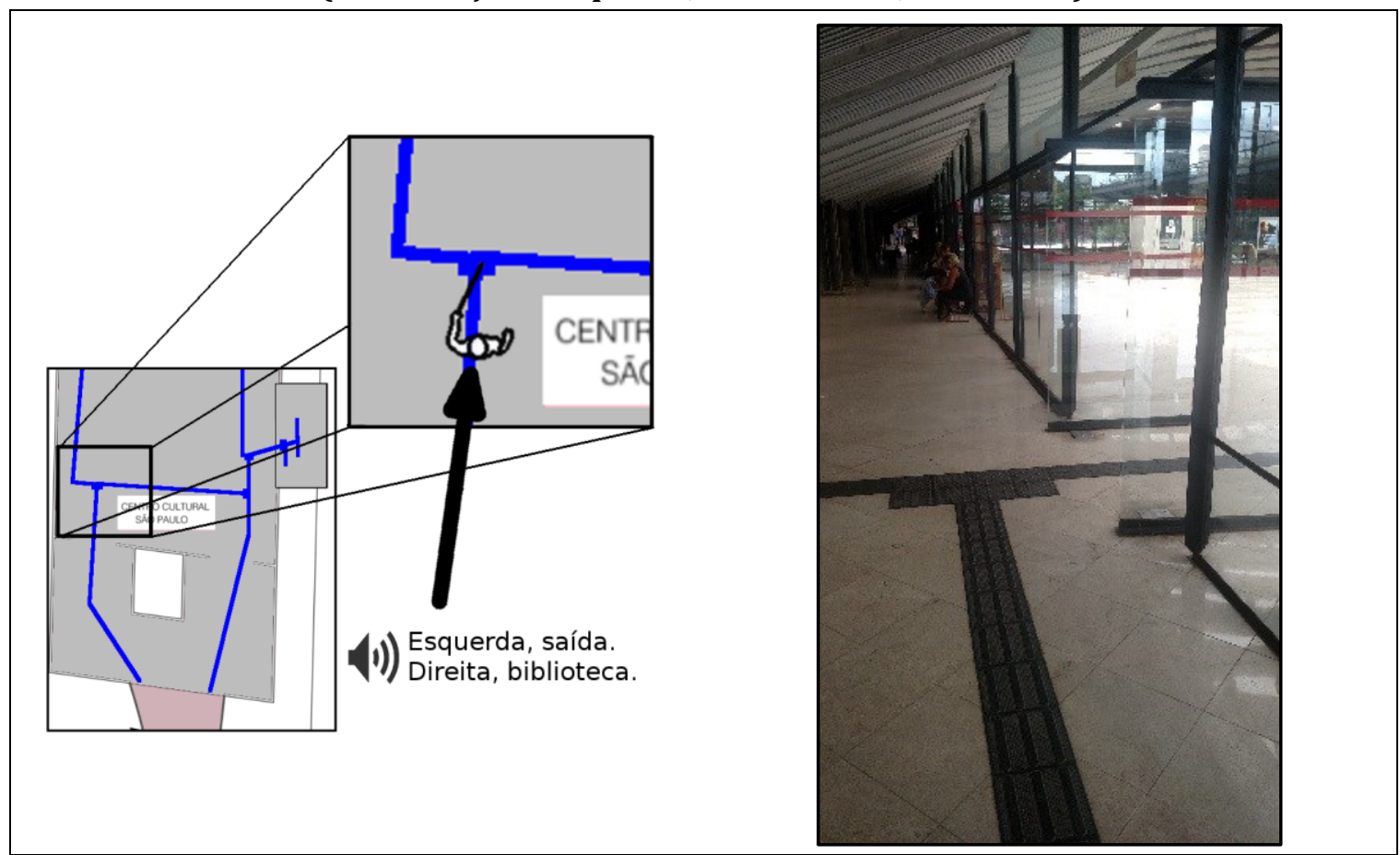

Fonte: do autor (2016)

Figura 56 - Junção do piso tátil leste com o oeste para a biblioteca Louis Braille - os voluntários não usaram

(verbalização: “Esquerda, biblioteca. Direita, saída para o Metrô Vergueiro”)

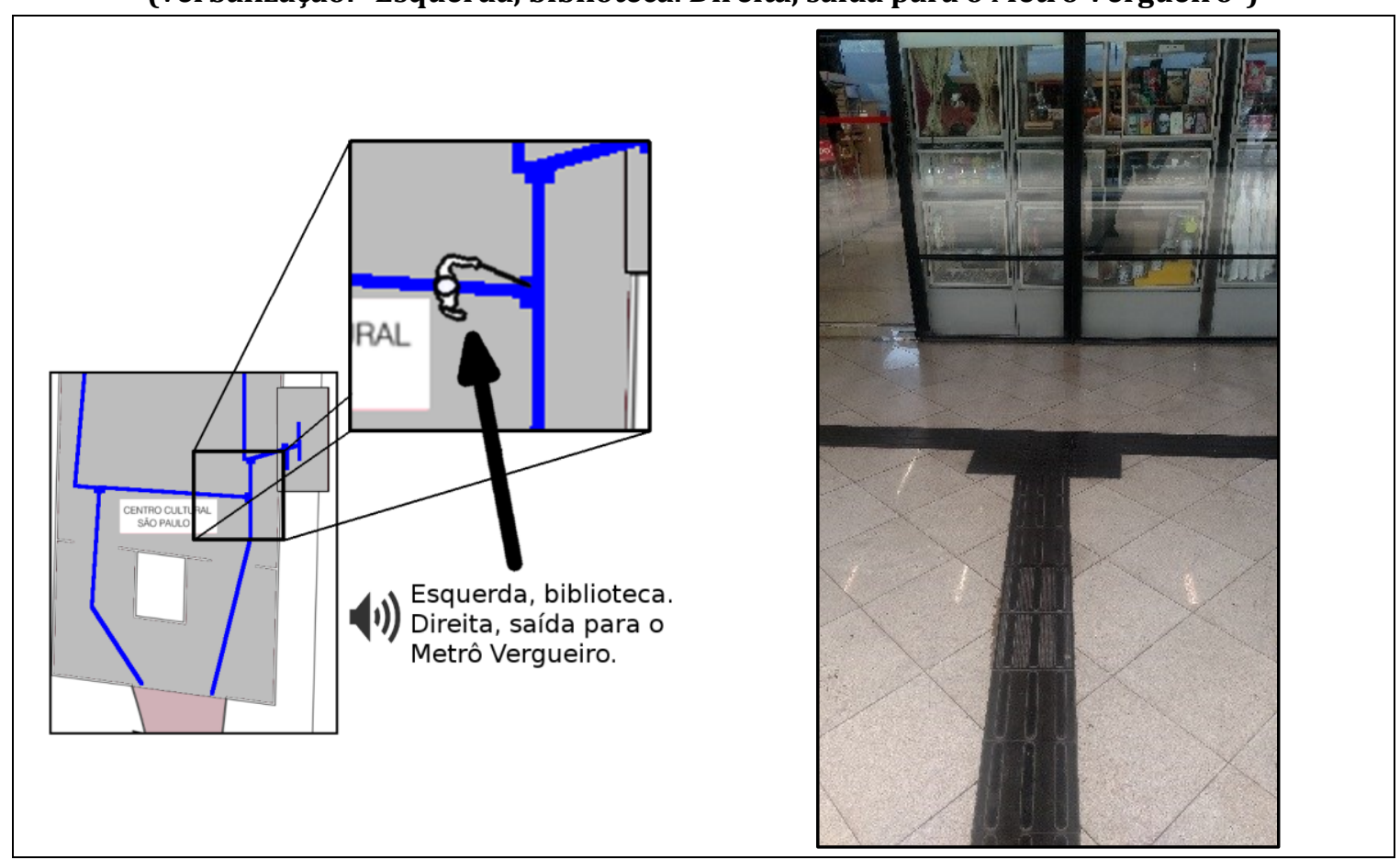

Fonte: do autor (2016) 
Figura 57 - Bifurcação para a biblioteca Louis Braille (verbalização: “Frente, lanchonete. Direita, biblioteca.”)

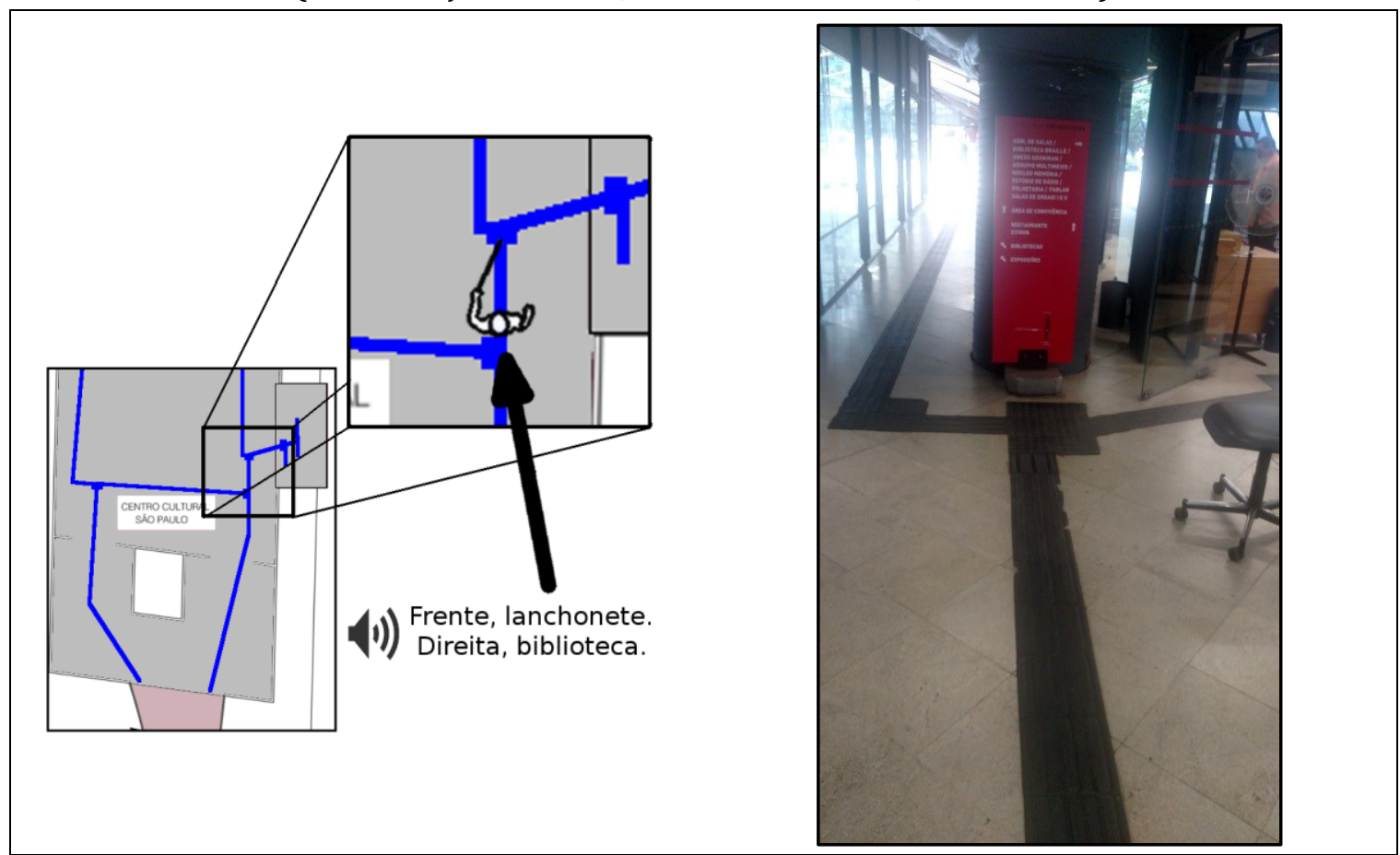

Fonte: do autor (2016)

Figura 58 - Entrada da biblioteca Louis Braille (verbalização: “Bem-vindo à biblioteca Louis Braille. Um atendente o acompanhará.”)

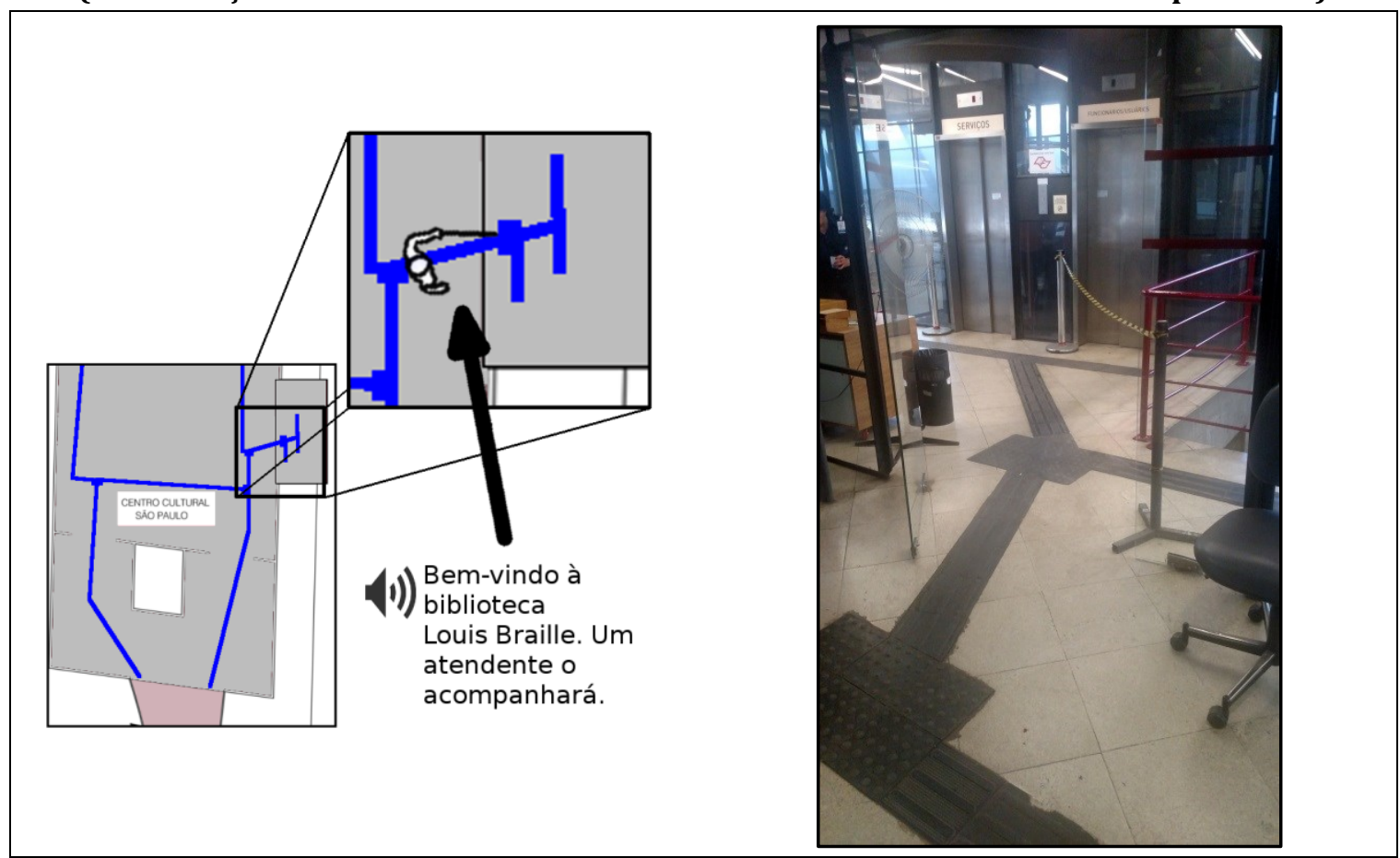

Fonte: do autor (2016) 



\section{APÊNDICE F: TERMOS DE CONSENTIMENTO LIVRE E ESCLARECIDO}

\section{MODELO FEMININO}

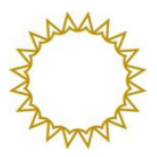

FAU - Faculdade de Arquitetura e Urbanismo USP - Universidade de São Paulo Mestrado em Design e Arquitetura

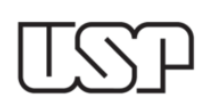

pg. $1 / 3$

TERMO DE CONSENTIMENTO LIVRE E ESCLARECIDO

Título da Pesquisa: Estudo sobre a usabilidade e intuitividade de aparelhos eletrônicos para navegação e orientação de pessoas com deficiência visual.

Pesquisador: Jaldomir da Silva Filho

Orientadora: Prof ${ }^{\mathrm{a}}$ Dr $^{\mathrm{a}}$ Denise Dantas

A Sra. está sendo convidada a participar desta pesquisa que tem como finalidade estudar a usabilidade e a intuitividade de interfaces eletrônicas sonoras vocais, sonoras não vocais e táteis para indicar situações ambientais para navegação e orientação de pessoas com deficiência visual..

Prevê-se uma conversa de cerca de 30 a 60 minutos para cada entrevista individual, cerca de 30 a 60 minutos para a entrevista em grupo, e cerca de 30 minutos para o acompanhamento nos locais definidos e conhecidos previamente, excluindo-se o tempo de deslocamento até os locais. Os passeios acompanhados serão realizados na cidade de São Paulo.

Este termo permite à Sra. a liberdade de se recusar a participar ou, caso tenha aceito em um primeiro momento, se recusar a continuar participando em qualquer fase da pesquisa, sem qualquer prejuízo para a Sra. Sempre que desejar, poderá pedir mais informações sobre a pesquisa por meio do telefone do pesquisador e, se necessário, por meio do telefone do Programa de Pós-Graduação da faculdade.

Caso aceite participar desse estudo, serão realizadas entrevistas de opinião individual por meio de uma conversa informal com o pesquisador, por meio de dinâmica de grupo com participação do pesquisador e de outros voluntários, e por meio da utilização de um equipamento de testes que o guiará por trajetos definidos no interior de instituições e em áreas públicas. Com estes procedimentos, o pesquisador estará buscando conhecer sobre a contribuição que interfaces eletrônicas que possuem voz, sons e vibração podem oferecer à mobilidade com independência e segurança. O pesquisador estará presente em todos os acompanhamentos, mesmo que de forma silenciosa para não interferir nos resultados da pesquisa, no objetivo de colher as informações necessárias para a pesquisa e também para garantir sua segurança. 


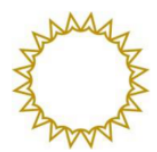

\section{FAU - Faculdade de Arquitetura e Urbanismo USP - Universidade de São Paulo} Mestrado em Design e Arquitetura

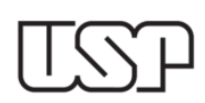

pg. $2 / 3$

Riscos e desconforto: a participação nesta pesquisa não traz complicações legais, não há procedimentos invasivos (exemplo: injeção, tomar remédio ou cortar a pele), portanto não apresenta risco ou prejuízo à sua saúde. Durante as caminhadas, a Sra. utilizará o aparelho celular e outro pequeno e leve aparelho preso à sua roupa ou mochila, com peso máximo de 150 gramas. Caso a Sra. perceba algum desconforto com o equipamento ou com a caminhada, os testes serão interrompidos.

Os procedimentos adotados nesta pesquisa obedecem a Resolução 510, art. 1, parágrafo único, item 1, de 7 de abril de 2016, da Comissão Nacional de Ética em Pesquisa do Conselho Nacional de Saúde.

Confidencialidade: todas as informações coletadas neste estudo são estritamente confidenciais. Somente o pesquisador e a orientadora terão conhecimento dos dados.

Benefícios: ao participar desta pesquisa, a Sra. terá a oportunidade de conhecer sobre tecnologias assistivas, contribuindo com o aprimoramento das informações de voz, som e vibração, e aspectos de interação de aparelhos eletrônicos portáteis para guiar pessoas com deficiência em locais públicos. Com a divulgação posterior dos resultados dessa pesquisa, será possível criar ou aprimorar aparelhos eletrônicos de guia, navegação e orientação para pessoas com deficiência visual.

Uso de imagem: o pesquisador precisa registrar as entrevistas e os passeios para que seja possível catalogar e compilar as informações obtidas. Assim, o pesquisador pede também, por meio deste, a autorização para registrar os eventos, sua imagem e sua voz por meio de gravações de áudio, vídeo e fotografias, requerendo a permissão para utilizar o conteúdo obtido exclusivamente para fins científicos relacionados a este estudo específico, por meio de confecção de livros, artigos e slides, observando os direitos da pessoa com deficiência de acordo com os decretos federais 3.298/1999 e 5.296/2004.

Pagamento: a Sra. não contribuirá financeiramente com valores para participar desta pesquisa, bem como nada será pago por sua participação.

Após estes esclarecimentos, solicitamos o seu consentimento de forma livre para participar desta pesquisa, por meio de sua assinatura. Não assine esse termo se ainda tiver dúvidas sobre ele ou sobre a pesquisa. 


\section{FAU - Faculdade de Arquitetura e Urbanismo USP - Universidade de São Paulo Mestrado em Design e Arquitetura

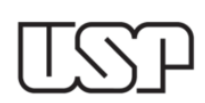

pg. $3 / 3$

"Tendo em vista os itens acima apresentados, eu, de forma livre e esclarecida, manifesto meu consentimento em participar desta pesquisa. Também confirmo que recebi cópia deste termo de consentimento, e autorizo a execução do trabalho de pesquisa e a divulgação dos dados obtidos neste estudo."

São Paulo, de de 2016 .

Nome e assinatura da participante

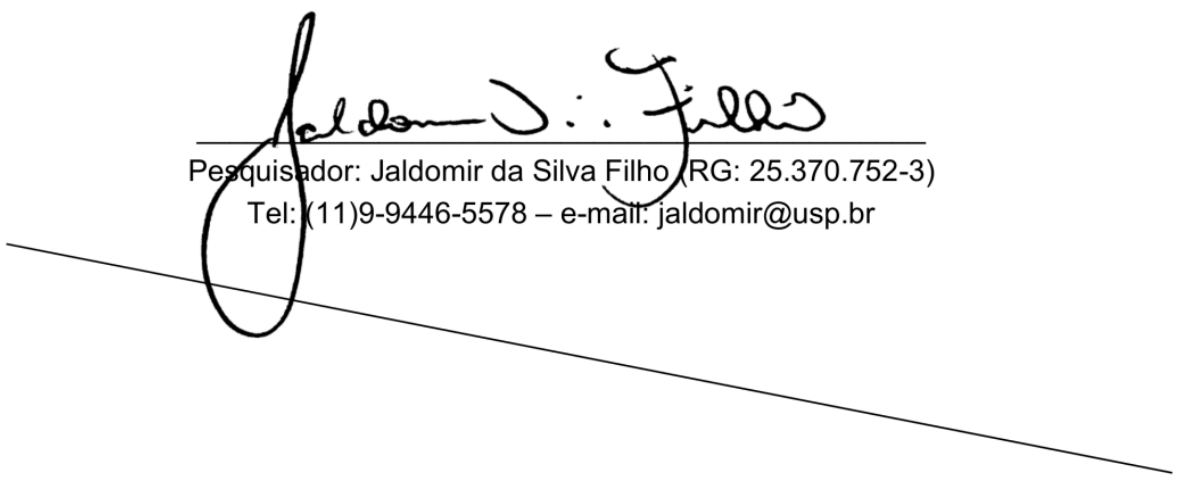

Programa de Pós Graduação da FAU:

Telefone (11) 3017-3150. E-mail: cpgfausec@usp.br

Programa de Pós Graduação

Faculdade de Arquitetura e Urbanismo da Universidade de São Paulo

Rua Maranhão, 88 - CEP 01240.000 - São Paulo/SP - Brasil - Tel. 3017-3150. 


\section{MODELO MASCULINO}

\section{FAU - Faculdade de Arquitetura e Urbanismo} USP - Universidade de São Paulo Mestrado em Design e Arquitetura

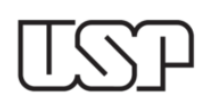

pg. $1 / 3$

\section{TERMO DE CONSENTIMENTO LIVRE E ESCLARECIDO}

Título da Pesquisa: Princípios para o design de audionavegação de ambientes públicos para pessoas com deficiência visual Pesquisador: Jaldomir da Silva Filho Orientadora: Prof ${ }^{a}$ Dr$^{\mathrm{a}}$ Denise Dantas

O Sr. está sendo convidado a participar desta pesquisa que tem como finalidade estudar a usabilidade e a intuitividade de interfaces eletrônicas sonoras vocais, sonoras não vocais e táteis para indicar situações ambientais para navegação e orientação de pessoas com deficiência visual..

Prevê-se uma conversa de cerca de 30 a 60 minutos para cada entrevista individual, cerca de 30 a 60 minutos para a entrevista em grupo, e cerca de 30 minutos para o acompanhamento nos locais definidos e conhecidos previamente, excluindo-se o tempo de deslocamento até os locais. Os passeios acompanhados serão realizados na cidade de São Paulo. Durante os passeios o Sr. utilizará o equipamento que indicará o caminho a ser percorrido, por meio de voz eletrônica em um aparelho de telefonia celular.

Este termo oferece ao $\mathrm{Sr}$. a liberdade de se recusar a participar ou, caso tenha aceito em um primeiro momento, se recusar a continuar participando em qualquer fase da pesquisa, sem qualquer prejuizo para o $\mathrm{Sr}$. Sempre que desejar, poderá solicitar mais informações sobre a pesquisa por meio do telefone do pesquisador e, se necessário, por meio do telefone do Programa de Pós-Graduação da faculdade.

Caso aceite participar desse estudo, serão realizadas entrevistas de opinião individual por meio de uma conversa informal com o pesquisador, por meio de dinâmica de grupo com participação do pesquisador e de outros voluntários, e por meio da utilização de um equipamento de testes que o guiará por trajetos definidos no interior de instituições e em áreas públicas. Com estes procedimentos, o pesquisador estará buscando conhecer sobre a contribuição que interfaces eletrônicas que possuem voz, sons e vibração podem oferecer à mobilidade com independência e segurança. $O$ pesquisador estará presente em todos os acompanhamentos, mesmo que de forma silenciosa para não interferir nos resultados da pesquisa, no objetivo de colher as informações necessárias para a pesquisa e também para garantir sua segurança. 


\section{FAU - Faculdade de Arquitetura e Urbanismo USP - Universidade de São Paulo Mestrado em Design e Arquitetura}

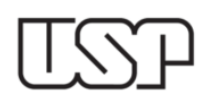

pg. $2 / 3$

Riscos e desconforto: a participação nesta pesquisa não traz complicações legais, não há procedimentos invasivos (exemplo: injeção, tomar remédio ou cortar a pele), portanto não apresenta riscos ou prejuízos à sua saúde. Durante as caminhadas, o Sr. utilizará o aparelho celular e outro pequeno e leve aparelho preso à sua roupa ou mochila, com peso máximo de 150 gramas. Caso o Sr. perceba algum desconforto com o equipamento ou com a caminhada, os testes serão interrompidos.

Embasamento legal: os procedimentos adotados nesta pesquisa obedecem a Resolução 510, art. 1, parágrafo único, item 1, de 7 de abril de 2016, da Comissão Nacional de Ética em Pesquisa do Conselho Nacional de Saúde.

Confidencialidade: todas as informações coletadas neste estudo são estritamente confidenciais. Somente o pesquisador e a orientadora terão conhecimento dos dados.

Benefícios: ao participar desta pesquisa, o Sr. terá a oportunidade de conhecer sobre tecnologias assistivas, contribuindo com o aprimoramento das informações de voz, som e vibração, e aspectos de interação de aparelhos eletrônicos portáteis para guiar pessoas com deficiência visual em locais públicos. Com a divulgação posterior dos resultados dessa pesquisa, será possível criar ou aprimorar aparelhos eletrônicos de guia, navegação e orientação para pessoas com deficiência visual.

Uso de imagem: o pesquisador precisa registrar as entrevistas e os passeios para que seja possível catalogar e compilar as informações obtidas. Assim, o pesquisador pede também, por meio deste, a autorização para registrar os eventos, sua imagem e sua voz, por meio de gravações de áudio, vídeo e fotografias, requerendo a permissão para utilizar o conteúdo obtido exclusivamente para fins científicos relacionados a este estudo específico, por meio de confecção de livros, artigos e slides, observando os direitos da pessoa com deficiência de acordo com os decretos federais 3.298/1999 e 5.296/2004.

Pagamento: o Sr. não contribuirá financeiramente com valores para participar desta pesquisa, bem como nada será pago por sua participação.

Após estes esclarecimentos, solicitamos o seu consentimento de forma livre para participar desta pesquisa, por meio de sua assinatura. Não assine esse termo se ainda tiver dúvidas sobre ele ou sobre a pesquisa. 


\section{FAU - Faculdade de Arquitetura e Urbanismo USP - Universidade de São Paulo Mestrado em Design e Arquitetura}

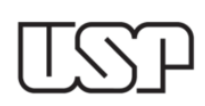

pg. $3 / 3$

"Tendo em vista os itens acima apresentados, eu, de forma livre e esclarecida, manifesto meu consentimento em participar desta pesquisa. Também confirmo que recebi cópia deste termo de consentimento, e autorizo a execução do trabalho de pesquisa e a divulgação dos dados obtidos neste estudo."

São Paulo, de de 2016 .

Nome e assinatura do participante

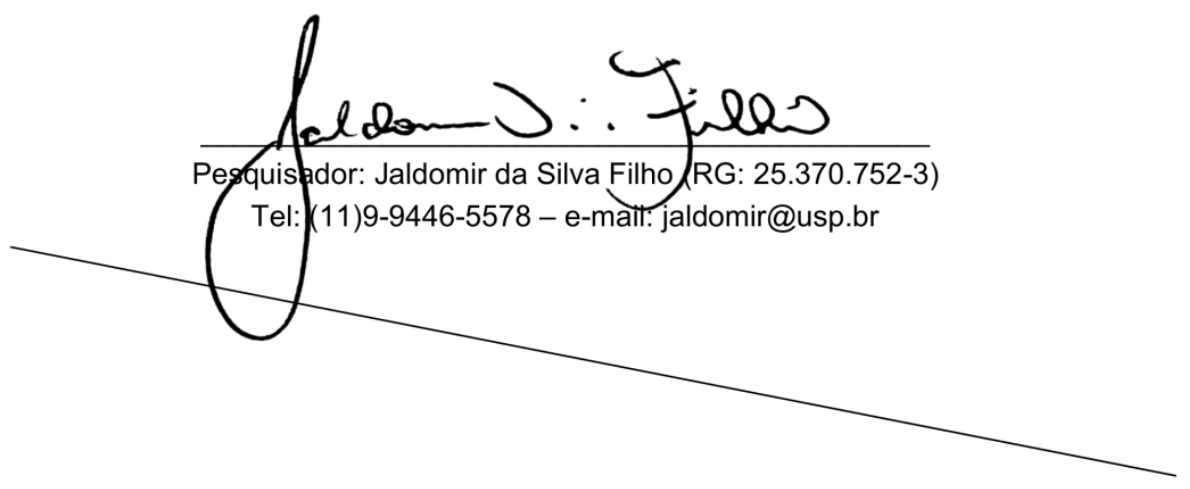

Programa de Pós Graduação da FAU:

Telefone (11) 3017-3150. E-mail: cpgfausec@usp.br 
APÊNDICE G: DISPONIBILIZAÇÃO (INTERNET) DAS FRASES DA AUDIONAVEGAÇÃO

* Utilizar um leitor de código de barras bidimensional (QRCode).

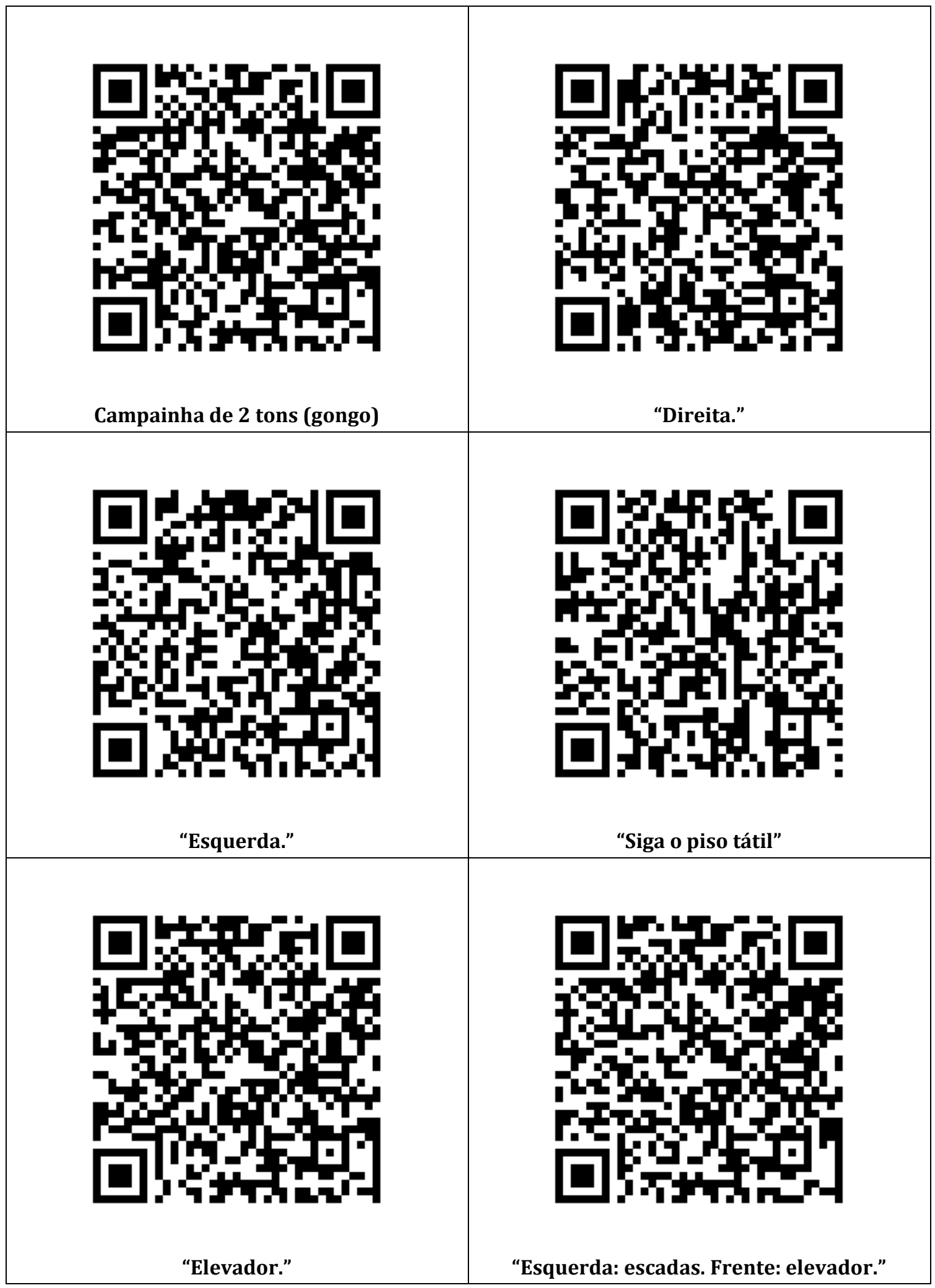




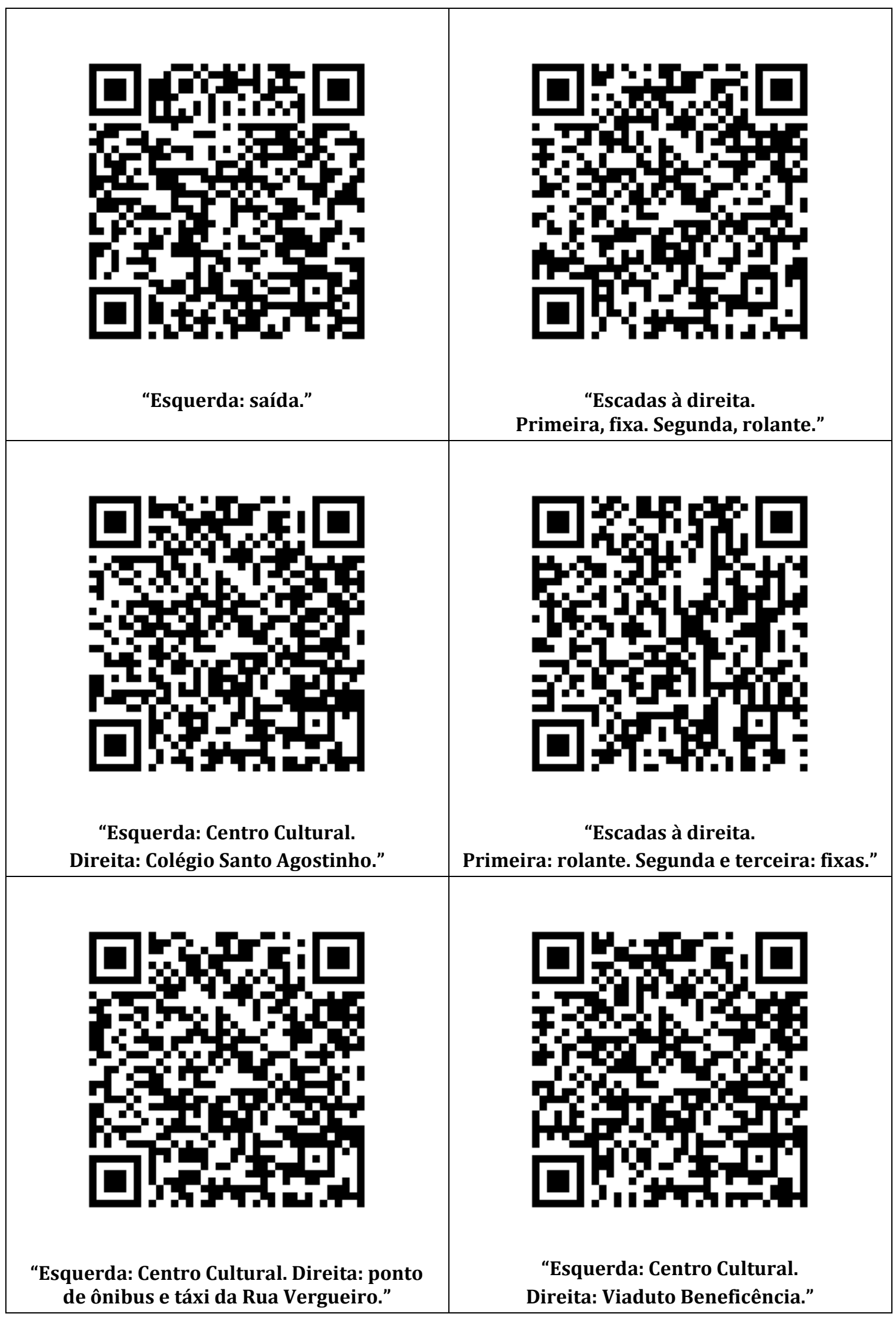




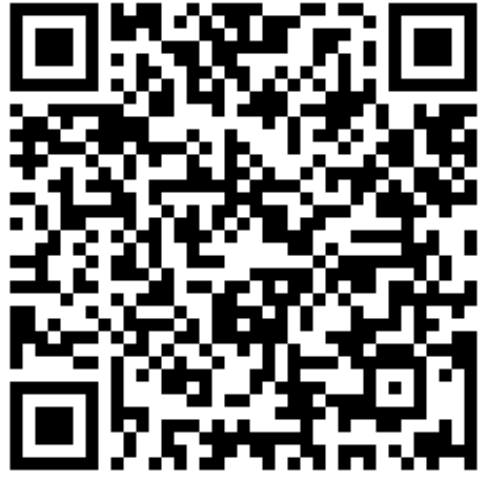

"Você está seguindo no sentido Centro Cultural São Paulo."

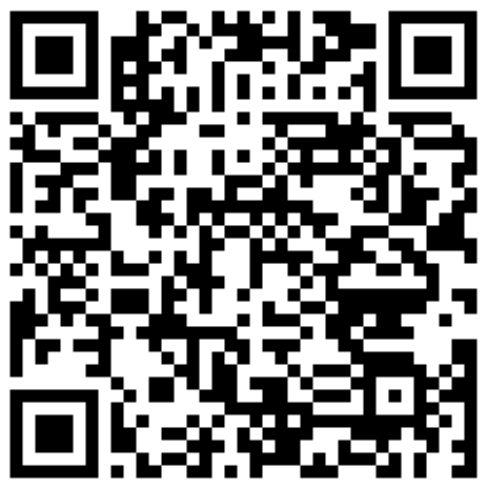

“Direita: biblioteca. Frente: lanchonete."

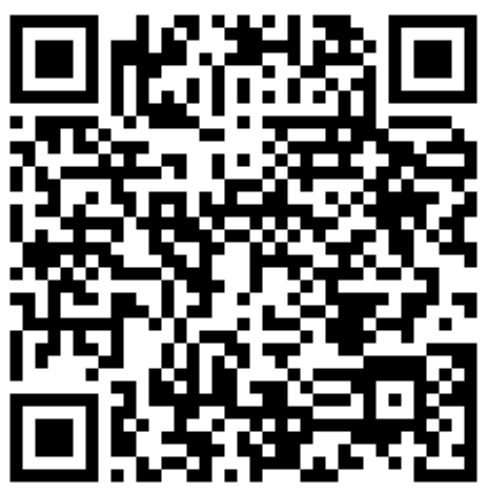

“Esquerda: biblioteca.

Direita: saída Metrô Vergueiro."

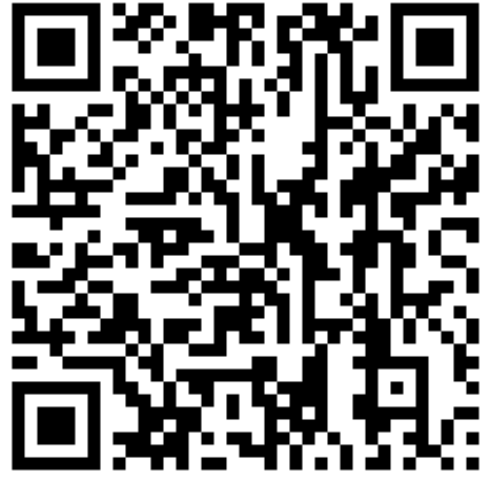

"Bem-vindo ao Centro Cultural São Paulo."

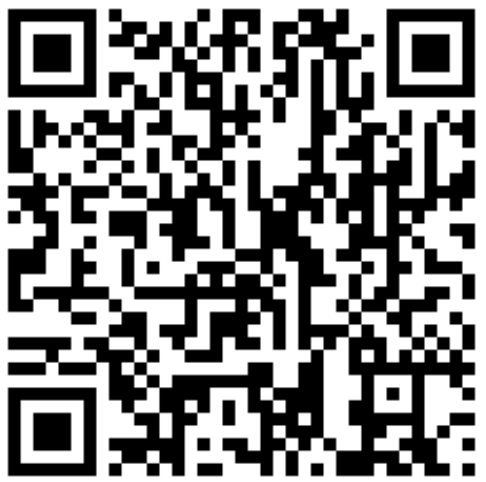

"Esquerda: pista de dança. Frente: Biblioteca."

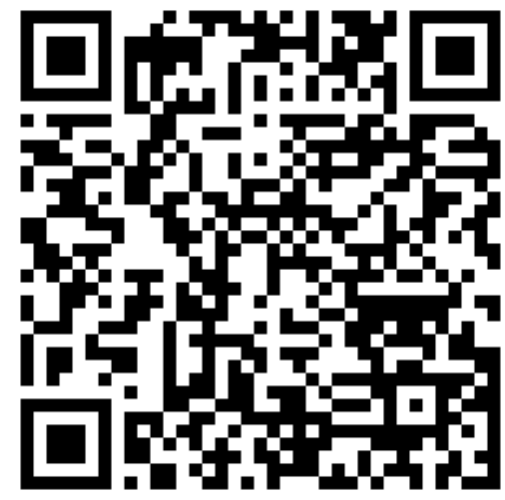

"Bem-vindo à Biblioteca Louis Braille. Um atendente o acompanhará." 